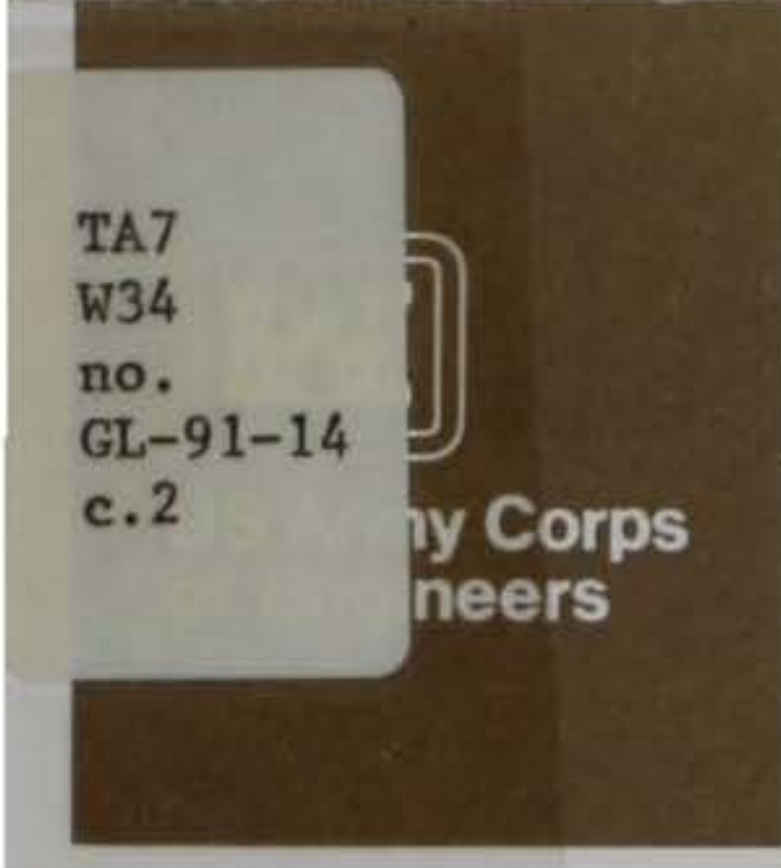

\title{
DEVELOPMENT OF A RELIABILITY-BASED METHOD FOR EVALUATING A PAVEMENT FEATURE
}

\author{
by \\ William P. Grogan \\ Geotechnical Laboratory \\ DEPARTMENT OF THE ARMY \\ Waterways Experiment Station, Corps of Engineers \\ 3909 Halls Ferry Road, Vicksburg, Mississippi 39180-6199

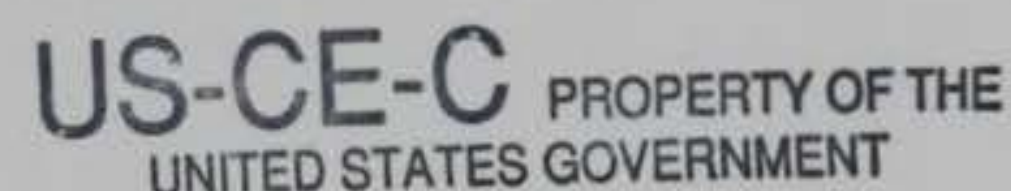

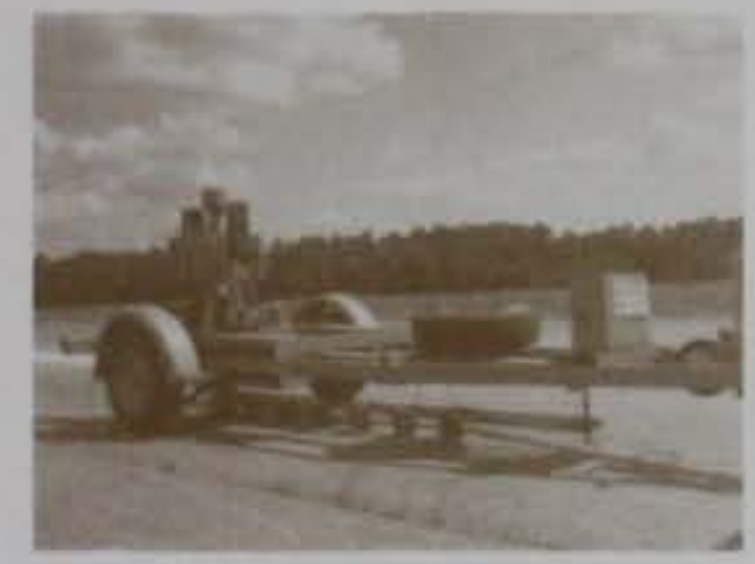

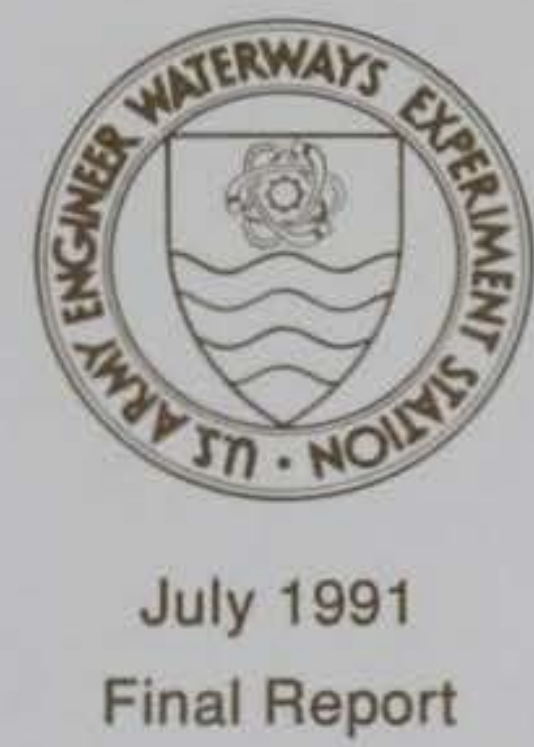

Approved For Public Release; Distribution Unlimited

RESEARCH LIBFARY

US ARMY ENGINEER WATERWAYS

EXPERIMENT STATION

VICKSBURG, MISSISSIPPI

Prepared for DEPARTMENT OF THE ARMY

US Army Corps of Engineers

Washington, DC 20314-1000 
Public reporting burden for this collection of information is estimated to average 1 hour per response, including the time for reviewing instructions, searching existing data sources. gathering and maintaining the data needed, and completing and reviewing the collection of information. Send comments regarding this burden estimate or any other aspect of this

\begin{tabular}{|c|c|c|}
\hline 1. AGENCY USE ONLY (Leave blank) & $\begin{array}{c}\text { 2. REPORT DATE } \\
\text { July } 1991\end{array}$ & $\begin{array}{c}\text { 3. REPORT TYPE AND DATES COVERED } \\
\text { Final report }\end{array}$ \\
\hline
\end{tabular}

4. TITLE AND SUBTITLE

Development of a Reliability-Based Method for

Evaluating a Pavement Feature

\section{FUNDING NUMBERS}

\section{AUTHOR(S)}

William P. Grogan

7. PERFORMING ORGANIZATION NAME(S) AND ADDRESS(ES)

USAE Waterways Experiment Station

Geotechnical Laboratory

3909 Halls Ferry Road

Vicksburg, MS 39180-6199

9. SPONSORING/MONITORING AGENCY NAME(S) AND ADDRESS(ES)

TONSORING / MONITORING

US Army Corps of Engineers

20 Massachusetts Avenue, NW

Washington, DC 20314-1000

\section{SUPPLEMENTARY NOTES}

Available from National Technical Information Service, 5285 Port Royal Road, Springfield, VA 22161.

12a. DISTRIBUTION/AVAILABILITY STATEMENT

12b. DISTRIBUTION CODE

Approved for public release; distribution unlimited

\section{ABSTRACT (Maximum 200 words)}

Nondestructive testing (NDT) is used to evaluate the structural capacity of in-place pavements. NDT is accomplished with the use of a falling weight deflectometer (FWD). The data obtained with the FWD are used to determine the modulus value of the layers in a pavement system. The modulus values are used to determine the structural capacity of the pavements in terms of allowable load, allowable passes, and overlay thickness requirements.

Because NDT provides a means of rapidly testing a pavement, many tests are conducted on a pavement feature. Currently, the method for evaluating a pavement feature uses the mean NDT. This study was conducted to investigate the effect of using the mean NDT. The results of this investigation provide a statistical approach for evaluating a pavement feature using NDT procedures at a user-defined level of reliability.

\begin{tabular}{|c|c|}
\hline \multicolumn{2}{|l|}{ 14. SUBJECT TERMS } \\
\hline See reverse. & \\
\hline $\begin{array}{l}\text { 17. SECURITY CLASSIFICATION } \\
\text { OF REPORT } \\
\text { Unclassified }\end{array}$ & $\begin{array}{l}\text { 18. SECURITY CLASSIFICATION } \\
\text { OF THIS PAGE } \\
\text { Unclassified }\end{array}$ \\
\hline
\end{tabular}

NSN 7540-01-280-5500

\section{SECURITY CLASSIFICATION
OF ABSTRACT Unclassified}

15. NUMBER OF PAGES 155

16. PRICE CODE 20. LIMITATION OF ABSTRACT 
14. (Continued).

Allowable gross load Allowable passes

Falling weight deflectometer

Impulse stiffness modulus

Modulus
Nondestructive testing

Overlays

Reliability

"+" distribution 
This study was conducted by the Geotechnical Laboratory (GL), US Army Engineer Waterways Experiment Station (WES), Vicksburg, Mississippi, as part of the work effort "Improved Nondestructive Testing Techniques in Pavement Evaluation" of the RDT\&E Program, AT40-PT-003. This study was conducted during the period from June 1990 to May 1991.

The study was conducted under the general supervision of $\mathrm{Dr}$. W. F. Marcuson III, Chief, GL; Mr. H. H. Ulery, Jr., Chief, Pavement Systems Division (PSD), GL. This report was produced under the direct supervision of Mr. J. W. Hall, Jr., Chief, Systems Analysis Branch (SAB), PSD. Personnel engaged in the compilation of the data for this study included Messrs. D. Alexander, A. Harrison, P. McCaffrey, and Ms. C. McCoy. This report was prepared by Mr. W. P. Grogan.

COL Larry B. Fulton, EN is the Commander and Director of WES. Dr. Robert W. Whalin is Technical Director. 
TABLE OF CONTENTS

PAGE

PREFACE ................................. 1

LIST OF TABLES . . . . . . . . . . . . . . . . . . . . . . . . iv

LIST OF FIGURES . . . . . . . . . . . . . . . . . . . . . . . . vii

CHAPTER

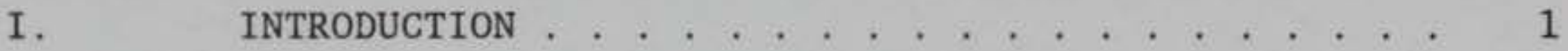

Purpose . . . . . . . . . . . . . . . . 3

Objective . . . . . . . . . . . . . . . . . . . . 3

Scope ................. . . . 3

II. REVIEW OF LITERATURE . . . . . . . . . . . . . 5

III. NONDESTRUCTIVE PAVEMENT TESTING . . . . . . . . . . 8

Description of Equipment . . . . . . . . . . . 8

Description of Data Produced by NDT Equipment . . . 10

NDT Evaluation Procedure . . . . . . . . . . 12

IV. DESCRIPTION OF FIELD TESTING PROGRAM . . . . . . . . 19

Description of Field Sites . . . . . . . . . . . . 19

Description of NDT Testing . . . . . . . . . . . . . 19

V. PRESENTATION AND ANALYSIS OF DATA . . . . . . . . . 23

Presentation of FWD Data . . . . . . . . . . . 23

Presentation and Discussion of NDT Evaluation

and Data. . . . . . . . . . . . . . . . . 25

Analysis and Discussion of Data . . . . . . . 30

VI DEVELOPMENT OF RELIABILITY-BASED PROCEDURE FOR

EVALUATING A PAVEMENT FEATURE . . . . . . . . . . . 41

Discussion of Evaluation Procedure . . . . . . . . . 42

Reliability-Based Evaluation Procedure . . . . . . . 47 
CHAPTER

PAGE

VII. SUMMARY, CONCLUSIONS, AND RECOMMENDATIONS . . . 49

Summary . . . . . . . . . . . . . . . . 49

Conclusions . . . . . . . . . . . . 50

Recommendations . . . . . . . . . . . 50

REFERENCES . . . . . . . . . . . . . . . . . . 52

APPENDIX A: SUPPLEMENTARY TABLES AND FIGURES . . . . . . . . 54 
1. Summary of Pavement Structures . . . . . . . . . . 20

2. Flexural Strength (psi) for Each Site with PCC . . . . . 22

3. Summary of ISM (Kips/inch) Results . . . . . . . . . . . 24

4. Summary of Modulus Values (psi). . . . . . . . . . . . . 27

5. Summary of Overlay (inches) Results . . . . . . . . 29

6. Summary of Allowable Gross Load (AGL) and Allowable Passes... . . . . . . . . . . . 30

7. Summary of CoV Values . . . . . . . . . . . . . . 31

8. ISM (Kips/inch) Results Compared to Existing Evaluation Procedure . . . . . . . . . . . . . . 34

9. AC Overlay (inches) Results Compared to Existing Evaluation Procedure . . . . . . . . . . 35

10. PCC Overlay (inches) Results Compared to Existing Evaluation Procedure . . . . . . . . . . 36

11. Allowable Passes Results Compared to Existing Evaluation Procedure . . . . . . . . . . . .

12. Allowable Gross Load (Kips) Results Compared to Existing Evaluation Procedure . . . . . . . . . . . .

13. Summary Comparison of Existing Evaluation Procedure Mean Test Number to Mean Test Number of Each Step of Evaluation Procedure . . . . . . . . . . . . . . .

14. Summary Comparison of 958 Reliability Test Number at Each Step of Evaluation Procedure . . . . . . . . . . . . . . 40

15. 958 Reliability Overlay Results . . . . . . . . . . 46

16. Site 1, Normalized Deflection Basins.......... 55 
17. Site 2, Normalized Deflection Basins . . . . . . . . 56

18. Site 3, Normalized Deflection Basins . . . . . . . . 57

19. Site 4, Normalized Deflection Basins . . . . . . . . 58

20. Site 5, Normalized Deflection Basins . . . . . . . . 59

21. Site 6, Normalized Deflection Basins . . . . . . . . . 60

22. Site 7, Normalized Deflection Basins .......... 61

23. Site 8 , Normalized Deflection Basins . . . . . . . . 62

24. Site 9, Normalized Deflection Basins . . . . . . . . 63

25. Site 10, Normalized Deflection Basins . . . . . . . . . 64

26. Site 11, Normalized Deflection Basins . . . . . . . 65

27. Site 12, Normalized Deflection Basins . . . . . . . 66

28. ISM (Kips/inch) vs Test Number, Sites 1-4...... 67

29. ISM (Kips/inch) vs Test Number, Sites 5-8 . . . . 68

30. ISM (Kips/inch) vs Test Number, Sites 9 - 12 . . . . . 69

31. Site 1, Layer Moduli (psi) vs Test Number . . . . . . 70

32. Site 2, Layer Moduli (psi) vs Test Number . . . . . . . 71

33. Site 3, Layer Moduli (psi) vs Test Number . . . . . . . 72

34. Site 4, Layer Moduli (psi) vs Test Number . . . . . . . 73

35. Site 5, Layer Moduli (psi) vs Test Number . . . . . . 74

36. Site 6, Layer Moduli (psi) vs Test Number . . . . . . 75

37. Site 7, Layer Moduli (psi) vs Test Number . . . . . . 76

38. Site 8, Layer Moduli (psi) vs Test Number . . . . . . . 77

39. Site 9, Layer Moduli (psi) vs Test Number . . . . . . 78

40. Site 10, Layer Moduli (psi) vs Test Number . . . . . . 79

41. Site 11, Layer Moduli (psi) vs Test Number . . . . . . 80 
42. Site 12, Layer Moduli (psi) vs Test Number . . . . . . 81

43. Site 1, Overlays vs Test Number . . . . . . . . . . . . 82

44. Site 2, Overlays vs Test Number . . . . . . . . . . . 83

45. Site 3 , Overlays vs Test Number . . . . . . . . . . . . 84

46. Site 4, Overlays vs Test Number . . . . . . . . . . 85

47. Site 5, Overlays vs Test Number . . . . . . . . . . 86

48. Site 6 , Overlays vs Test Number . . . . . . . . . . 87

49. Site 7, Overlays vs Test Number . . . . . . . . . 88

50. Site 8 , Overlays vs Test Number . . . . . . . . . 89

51. Site 9, Overlays vs Test Number . . . . . . . . . . 90

52. Site 10, Overlays vs Test Number . . . . . . . . . . 91

53. Site 11, Overlays vs Test Number . . . . . . . . . . 92

54. Site 12, Overlays vs Test Number . . . . . . . . . . . 93

55. Allowable Gross Load (AGL) and Allowable Passes
vs Test Number, Sites 1 and 2

56. Allowable Gross Load (AGL) and Allowable Passes
vs Test Number, Sites 3 and 4 . . . . . . . . 95

57. Allowable Gross Load (AGL) and Allowable Passes
vs Test Number, Sites 5 and 6

58. Allowable Gross Load (AGL) and Allowable Passes vs Test Number, Sites 7 and 8 . . . . . . . . . . 97

59. Allowable Gross Load (AGL) and Allowable Passes vs Test Number, Sites 9 and 10 . . . . . . . . . . . . 98

60. Allowable Gross Load (AGL) and Allowable Passes vs Test Number, Sites 11 and 12 . . . . . . . . . . . 


\section{LIST OF FIGURES}

FIGURE

PAGE

1. Photograph of Dynatest FWD . . . . . . . . . . . . . . 9

2. Schematic of Deflection Basin . . . . . . . . . . . 11

3. Schematic of Airfield Pavement Divided into Features . . 15

4. Layout of NDT Test Locations . . . . . . . . . . . . 21

5. Site 1, ISM vs Test Number . . . . . . . . . . . . . 100

6. Site 2, ISM vs Test Number........... . . 100

7. Site 3, ISM vs Test Number . . . . . . . . . . . . . 101

8. Site 4, ISM vs Test Number . . . . . . . . . . . . . 101

9. Site 5, ISM vs Test Number . . . . . . . . . . . . 102

10. Site 6, ISM vs Test Number . . . . . . . . . . 102

11. Site 7, ISM vs Test Number . . . . . . . . . . . . 103

12. Site 8, ISM vs Test Number . . . . . . . . . . 103

13. Site 9, ISM vs Test Number . . . . . . . . . . . . . . 104

14. Site 10, ISM vs Test Number . . . . . . . . . . . 104

15. Site 11, ISM vs Test Number . . . . . . . . . . . . 105

16. Site 12, ISM vs Test Number . . . . . . . . . . 105

17. Site 1, Subgrade Modulus vs Test Number . . . . . . . . 106

18. Site 2, PCC Modulus vs Test Number . . . . . . . . . . . 106

19. Site 2, Subgrade Modulus vs Test Number . . . . . . . . 107

20. Site 3, PCC Modulus vs Test Number . . . . . . . . . . . 107

21. Site 3, Subgrade Modulus vs Test Number . . . . . . . . 108 
FIGURE

22. Site 4, Subgrade Modulus vs Test Number . . . . . . . . 108

23. Site 5, AC Modulus vs Test Number . . . . . . . . . 109

24. Site 5, Base Modulus vs Test Number . . . . . . . . . 109

25. Site 5, Subgrade Modulus vs Test Number . . . . . . . . 110

26. Site 6, AC Modulus vs Test Number . . . . . . . . . 110

27. Site 6, Base Modulus vs Test Number . . . . . . . . . . 111

28. Site 6, Subgrade Modulus vs Test Number . . . . . . . . 111

29. Site 7, AC Modulus vs Test Number . . . . . . . . . 112

30. Site 7, Base Modulus vs Test Number . . . . . . . . . 112

31. Site 7, Subgrade Modulus vs Test Number . . . . . . . 113

32. Site 8, AC Modulus vs Test Number . . . . . . . . . . . 113

33. Site 8, Base Modulus vs Test Number . . . . . . . . . . 114

34. Site 8, Subgrade Modulus vs Test Number . . . . . . . . 114

35. Site 9, PCC Modulus vs Test Number . . . . . . . . . 115

36. Site 9, Subgrade Modulus vs Test Number . . . . . . . . 115

37. Site 10, AC Modulus vs Test Number . . . . . . . . . . . 116

38. Site 10, PCC Modulus vs Test Number . . . . . . . . . . 116

39. Site 10, Subgrade Modulus vs Test Number . . . . . . . . 117

40. Site 11, PCC Modulus vs Test Number . . . . . . . . . . 117

41. Site 11, Base Modulus vs Test Number . . . . . . . . . . 118

42. Site 11, Subgrade Modulus vs Test Number . . . . . . . . 118

43. Site 12, AC Modulus vs Test Number . . . . . . . . . 119

44. Site 12, PCC Modulus vs Test Number . . . . . . . . . . 119

45. Site 12, Subgrade Modulus vs Test Number . . . . . . . . 120

46. Site 1, AC Overlay vs Test Number . . . . . . . . . 121 
47. Site 1, PCC Overlay vs Test Number . . . . . . . . . 121

48. Site 2, AC Overlay vs Test Number . . . . . . . . . . 122

49. Site 2, PCC Overlay vs Test Number . . . . . . . . . 122

50. Site 3, AC Overlay vs Test Number . . . . . . . . . 123

51. Site 3, PCC Overlay vs Test Number . . . . . . . . 123

52. Site 4, AC Overlay vs Test Number . . . . . . . . . 124

53. Site 4, PCC Overlay vs Test Number . . . . . . . . 124

54. Site 5, AC Overlay vs Test Number ........... 125

55. Site 6, AC Overlay vs Test Number ........... 125

56. Site 7, AC Overlay vs Test Number . . . . . . . . . . 126

57. Site 8, AC Overlay vs Test Number . . . . . . . . . 126

58. Site 9, AC Overlay vs Test Number . . . . . . . . . . 127

59. Site 9, PCC Overlay vs Test Number . . . . . . . . . 127

60. Site 10, AC Overlay vs Test Number . . . . . . . . . . 128

61. Site 10, PCC Overlay vs Test Number . . . . . . . . . 128

62. Site 11, AC Overlay vs Test Number . . . . . . . . . 129

63. Site 11, PCC Overlay vs Test Number . . . . . . . . . 129

64. Site 12, AC Overlay vs Test Number . . . . . . . . . . 130

65. Site 12, PCC Overlay vs Test Number . . . . . . . . . 130

66. Site 1, Allowable Gross Load vs Test Number . . . . . . 131

67. Site 2, Allowable Gross Load vs Test Number . . . . . . 131

68. Site 3, Allowable Gross Load vs Test Number . . . . . . 132

69. Site 4, Allowable Gross Load vs Test Number . . . . . . 132

70. Site 5, Allowable Gross Load vs Test Number . . . . . 133

71. Site 6, Allowable Gross Load vs Test Number . . . . . . 133 
72. Site 7, Allowable Gross Load vs Test Number . . . . . . 134

73. Site 8, Allowable Gross Load vs Test Number . . . . . . 134

74. Site 9, Allowable Gross Load vs Test Number . . . . . 135

75. Site 10, Allowable Gross Load vs Test Number . . . . . 135

76. Site 11, Allowable Gross Load vs Test Number . . . . . 136

77. Site 12, Allowable Gross Load vs Test Number . . . . . . 136

78. Site 1, Allowable Passes vs Test Number . . . . . . 137

79. Site 2, Allowable Passes vs Test Number . . . . . . . 137

80. Site 3, Allowable Passes vs Test Number . . . . . . . . 138

81. Site 4, Allowable Passes vs Test Number . . . . . . . 138

82. Site 5, Allowable Passes vs Test Number . . . . . . . 139

83. Site 6, Allowable Passes vs Test Number . . . . . . 139

84. Site 7, Allowable Passes vs Test Number . . . . . . . 140

85. Site 8, Allowable Passes vs Test Number . . . . . . . 140

86. Site 9, Allowable Passes vs Test Number . . . . . . 141

87. Site 10, Allowable Passes vs Test Number . . . . . . . . 141

88. Site 11, Allowable Passes vs Test Number . . . . . . . . 142

89. Site 12, Allowable Passes vs Test Number . . . . . . . 142 


\section{DEVELOPMENT OF A RELIABILITY-BASED METHOD FOR \\ EVALUATING A PAVEMENT FEATURE}

CHAPTER I

INTRODUCTION

Nondestructive testing (NDT) is used to evaluate the structural capacity of in-place pavements. The Pavement Systems Division (PSD), Waterways Experiment Station (WES), provides airfield pavement evaluation services and sets forth criteria to be used by Department of Defense agencies, such as the Army and the Air Force. NDT conducted by the PSD is accomplished with the use of a falling weight deflectometer. A falling weight deflectometer is a pavement testing device that applies an impulse load to a pavement and then measures a deflected area induced by the load. The data obtained with the deflectometer are used to perform a nondestructive evaluation of the pavements tested. The results of the nondestructive evaluation include allowable passes and allowable loads of a design aircraft that the pavement tested can support, and the overlays required for the pavement to sustain the design aircraft at the design pass level.

The deflectometer allows for the rapid testing of a pavement; therefore, many tests are performed on each feature to be evaluated. A feature is an area of pavement of like cross-section subjected to similar traffic. For example, an airfield taxiway or the center portion of a runway would be a feature. Although a great deal of NDT test data are collected on a feature, the present method of 
evaluation uses one representative NDT test for the evaluation of the entire feature. The NDT test closest to the mean of all the NDT tests conducted on a feature is considered the representative NDT test, and is referred to as the mean NDT test. Sponsors of the nondestructive pavement evaluation program have expressed some concern as to the reliability of using the mean NDT test for the evaluation of a pavement feature. The reason for concern is that a study has not been conducted to determine the reliability of using the mean NDT test as opposed to another NDT test for evaluating a pavement feature. What reliability level is provided by using the mean NDT test for evaluating a pavement feature? Is there a method for evaluating a pavement feature at a user-defined level of reliability?

The term reliability for this study is defined as the probability that the pavement will not fail before it has sustained the design loads. A 95 percent reliability would mean that 95 percent of the pavement area would not fail, or 5 percent of the pavement area would be expected to fail before the design life of the pavement was reached.

Several alternatives have been suggested by users of the NDT evaluation procedure for choosing the NDT test to be used for evaluating a pavement feature. Some of the suggested alternatives include the mean NDT test plus one standard deviation, the mean plus two standard deviations, or the NDT test where 90 percent of the tests show stiffer pavements. To date, a study has not been conducted to determine the reliability of these alternatives. 


\section{Purpose}

The purpose of this study was to investigate the reliability of using the mean NDT test for the evaluation of a pavement feature. In addition, a method was to be developed for determining the NDT test that would provide a user-defined level of reliability in the evaluation of a pavement feature. The documentation of this work provides strong support for requiring the evaluation of all NDT tests conducted on a pavement feature. The data obtained by evaluating all NDT tests on a pavement feature provide information for performing a reliability-based evaluation.

\section{Objective}

The objective of this research was to determine the reliability of using the mean NDT test for evaluating a pavement feature. Also, a method was to be developed to determine the NDT test to be used for evaluating a pavement feature at a user-defined reliability level.

\section{Scope}

The scope of this study included a review of available literature, field testing, and data analysis. Specific goals of the field testing were to provide data that would have reasonable and realistic variation in NDT results for airfield pavements, and provide the data required to perform an NDT evaluation of several airfield pavement features. Results of the NDT evaluation were to be used to determine the consequences, in terms of reliability, of using the NDT test closest to the mean for evaluating a pavement feature. 
The data were also to be used to develop a method for determining the NDT test that would provide a user-defined level of reliability using the NDT evaluation procedure for a pavement feature.

Several airfield pavements were included in this study to ensure that any phenomena that may be associated with one particular pavement type or site would not affect the results of the study. NDT data were collected at twelve sites from airfields around the southeastern United States. Each site was a single pavement feature. The twelve sites consisted of three pavement types: flexible, rigid, and composite (flexible over rigid). There were four sites for each of the three pavement types. 
CHAPTER II

REVIEW OF LITERATURE

The nondestructive testing (NDT) procedure for evaluating airfield pavements involves conducting several tests for each feature being evaluated. The required number and spacing of NDT tests to be conducted on a feature is dependent on the type of evaluation being performed as defined in ASTM D 4695 (2). A feature is an area of pavement of like cross-section subjected to similar traffic (15). In addition, a feature is the largest area of pavement that can be evaluated as a single entity.

The results of the NDT evaluation include allowable passes and allowable loads for a design aircraft that the pavement can support, and the overlays required for the pavement to support the design aircraft at the design pass level. From a design, construction, and operations point of view, it is beneficial to evaluate an entire feature as one entity and assign a single set of results to the feature. If significant differences are discovered in the NDT data collected for a feature, the feature may be divided into sections. The sections may be evaluated separately and different results assigned to each section. However, different results, particularly overlay requirements, cannot be assigned to each area of pavement related to every NDT test conducted on a feature. Because of the 
number and spacing of NDT tests, it would be virtually impossible to construct a pavement overlay with different thicknesses at each NDT test location. Also, different overlay requirements for each NDT test location would result in an unacceptably rough pavement surface. Because data provided by many NDT tests are reduced to one set of results, the question of how to reduce the NDT data and still provide reliable results has existed since the introduction of NDT. Some of the first nondestructive pavement testing work developed by Green (9) involved the use of vibratory loading of the pavement and the measurement of dynamic stiffness moduli (DSM). Green suggested that the mean DSM minus one standard deviation be used as the representative value for evaluating a pavement feature. In 1978 an evaluation procedure developed for the U.S. Army by Hall (10), suggested the use of the statistical mean (average) DSM for evaluating a pavement feature.

State-of-the-art NDT of pavements uses an impulse loading device that measures a deflection basin. This procedure can be done more rapidly and provide more data then the vibratory testing procedures used in the 1970 's. The large volume of data collected by modern NDT equipment must be reduced to provide representative and reliable results for evaluating a pavement feature. The method presently used by Department of Defense (DoD) agencies chooses a representative field-measured deflection basin for evaluating a pavement feature. The procedure for determining the representative deflection basin compares the actual field-measured deflection basins to the mean of the deflection basins collected for a feature to be 
evaluated. The field-measured deflection basin closest to the mean is used for the evaluation of the feature. Alexander (1) discusses a procedure for selecting the representative deflection basin. The procedure is further discussed in Chapter III of this study. The procedure of using the mean deflection basin as the representative test has not been investigated as to its reliability. Because of concerns of the reliability of the present evaluation procedure by some users, a study to determine the reliability of using the current procedure and the development of a reliabilitybased procedure for evaluating a pavement feature was found to be necessary. This study provides a procedure for evaluating a pavement feature at a specified level of reliability. 
CHAPTER III

NONDESTRUCTIVE PAVEMENT TESTING

\section{Description of Equipment}

A Dynatest Model 8003 falling weight deflectometer (FWD) was used to collect the NDT data for this study. Figure 1 shows a photograph of the Dynatest FWD. The FWD is an impulse load device that applies a single transient load of approximately 25 to 30 millisecond duration. With this trailer-mounted device, a dynamic force is applied to the pavement surface by dropping a weight onto a set of rubber cushions which results in an impulse loading on an underlying circular plate 11.8 inches in diameter in contact with the pavement. The applied force is measured with a load cell. The drop height of the weights can be varied from 0 to 15.7 inches to produce a force from 0 to approximately 25,000 pounds. The pavement deflection is measured with velocity transducers. Measured velocities are electronically integrated to give deflections at the center of the load plate (D1) and at distances of $12,24,36,48,60$, and 72 inches (D2-D7) from the center of the load plate in order to obtain deflection basin measurements. The FWD is controlled by a NEC PowerMate portable computer which also records the output data. The testing system is powered by batteries on the trailer which are charged by a heavy-duty alternator on the towing vehicle. 


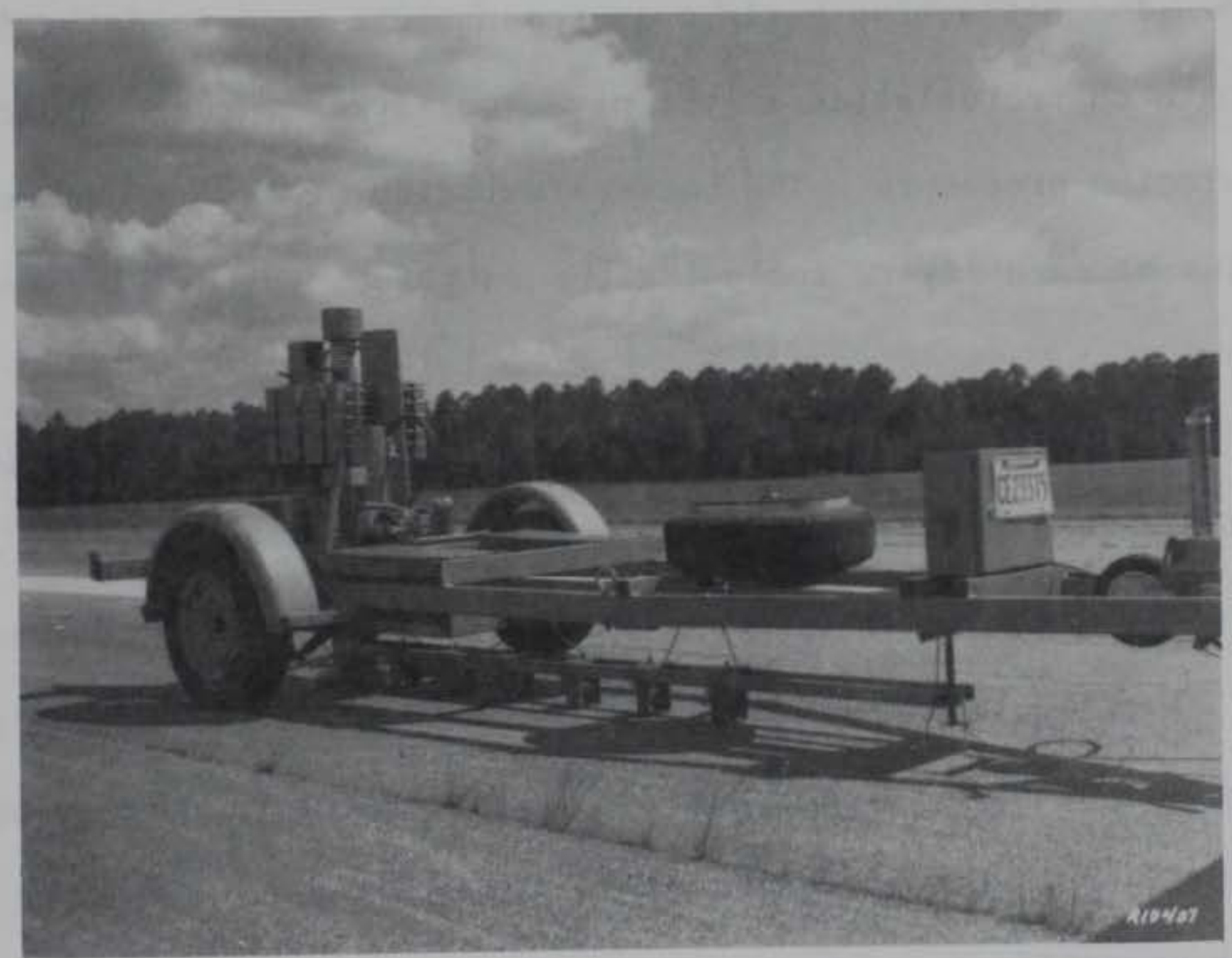

Figure 1. Photograph of Dynatest FWD 
Description of Data Produced by NDT Equipment

The NDT equipment produces data that are used for evaluating a pavement. The data of primary importance produced by the falling weight deflectometer are the deflection basins. A deflection basin consists of an applied force and surface deflections at offset distances from the load. Figure 2 shows a schematic of a deflection basin. The deflection basin measurements are used to determine strength characteristics of the pavement layers through a backcalculation procedure. The back-calculation procedure determines the modulus of each layer, including the subgrade, in the pavement system.

Impulse Stiffness Modulus (ISM) values are also determined from the deflection data. The ISM is the slope (load/deflection) of the plot of the impulse load versus the deflection at the first sensor (D1). The ISM is a measure of the relative stiffness of the pavement at the location of the NDT test. The ISM can be used to group test results into pavement sections by defining areas of relatively different stiffness.

In addition to the deflection basin, the falling weight deflectometer records other pertinent data relative to a NDT test. The location of the testing is recorded either by a feature name or a code that has been set up to define where the testing is being conducted. The station or test number defining the exact location of the test within the feature is also recorded. The date and time of testing is automatically recorded when each test is conducted. The pavement temperature and the air temperature can also be recorded. 


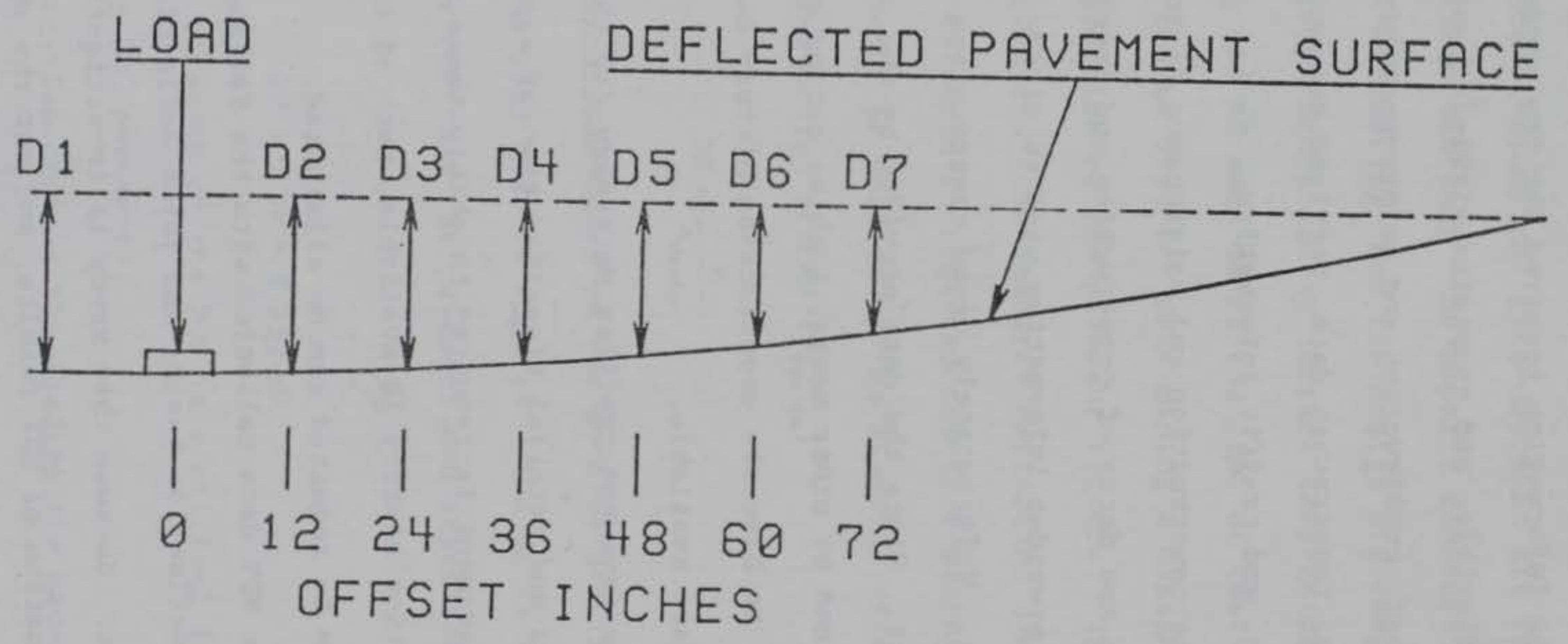

(Note: D1 is actually measured at the center of the load plate.) 


\section{NDT Evaluation Procedure}

\section{Data Requirements}

The information required for the nondestructive evaluation of rigid, flexible, and composite airfield pavements includes the following: construction and maintenance history, pavement profiles, NDT data, temperature data, portland cement concrete (PCC) flexural strength, and traffic information.

The construction and maintenance history consists of as-built drawings and dates of construction and overlays. The construction history provides information used to divide the pavement into features. Unfortunately, good construction history records often do not exist. Since the data provided by the construction history can be obtained by other means, such as coring of the pavement, it is not critical to have the construction history data, but it is beneficial if they are available.

The pavement profiles necessary for the NDT evaluation include thickness and material classification of each pavement layer. Coring of the pavement is required to obtain these data. If the construction history is available, much of the coring that would otherwise be required can be eliminated.

The NDT data collected with the falling weight deflectometer include deflection basins and joint deflection tests on PCC pavements. Because this study is investigating the variability in the evaluation of NDT results, and not the ability of the joints to transfer loads, joint deflection lests were not included. 
Temperature data may be collected for flexible and composite pavements to determine the modulus of the asphalt concrete (AC). The temperature data collected include the five-day mean air temperature (for the five days prior to testing), the asphalt concrete surface temperature at the time of testing, and the design air temperature. The five-day mean air temperature and $\mathrm{AC}$ surface temperature data can be used for determining the $\mathrm{AC}$ modulus at the time of testing. The design air temperature can be used for determining a design AC modulus used in the evaluation of the pavement feature. The AC modulus may also be determined from measured deflection basins.

The PCC flexural strength is required for determining the design factor (DF). The DF is defined as the flexural strength (R) of the PCC divided by the design stress $\left(\sigma_{\text {design }}\right)$.

$$
D F=\frac{R}{\sigma_{\text {design }}}
$$

The design stress is calculated based on the modulus and thickness of the PCC pavement and the load that is applied. The DF is related to the number of coverages (C) that the pavement can experience before failure.

$$
D F=0.50+0.25 \log C
$$

Therefore the flexural strength of the PCC is a critical item required for evaluating PCC pavements.

The traffic information defines the loading the pavement will experience. The loads a pavement will have to withstand are required for evaluating a pavement. 
Evaluation Procedure

The procedure outlined here for evaluating pavements is based on a layered linear elastic model that characterizes multilayered pavement systems. The purpose of this study is not to evaluate or verify the evaluation procedure, but rather to investigate the variabilities in results that might be expected with similar materials and to determine a means of providing a reliability-based method for evaluating a particular pavement feature. However, the evaluation procedure does need to be described in some degree so as to define what is being compared.

The first step in evaluating an airfield pavement is to divide the pavement into features. A feature is defined as a pavement area of like cross-section subjected to similar traffic. Figure 3 shows a schematic of an airfield divided into features. The data required to divide an airfield into features are the thickness and material classification of each layer of each pavement, and the traffic patterns of the aircraft operating on the pavements. The traffic patterns are determined from the layout of the airfield and from airport operations personnel. The thickness and material classification of each layer of each feature are determined through construction drawings or coring of the pavements. 


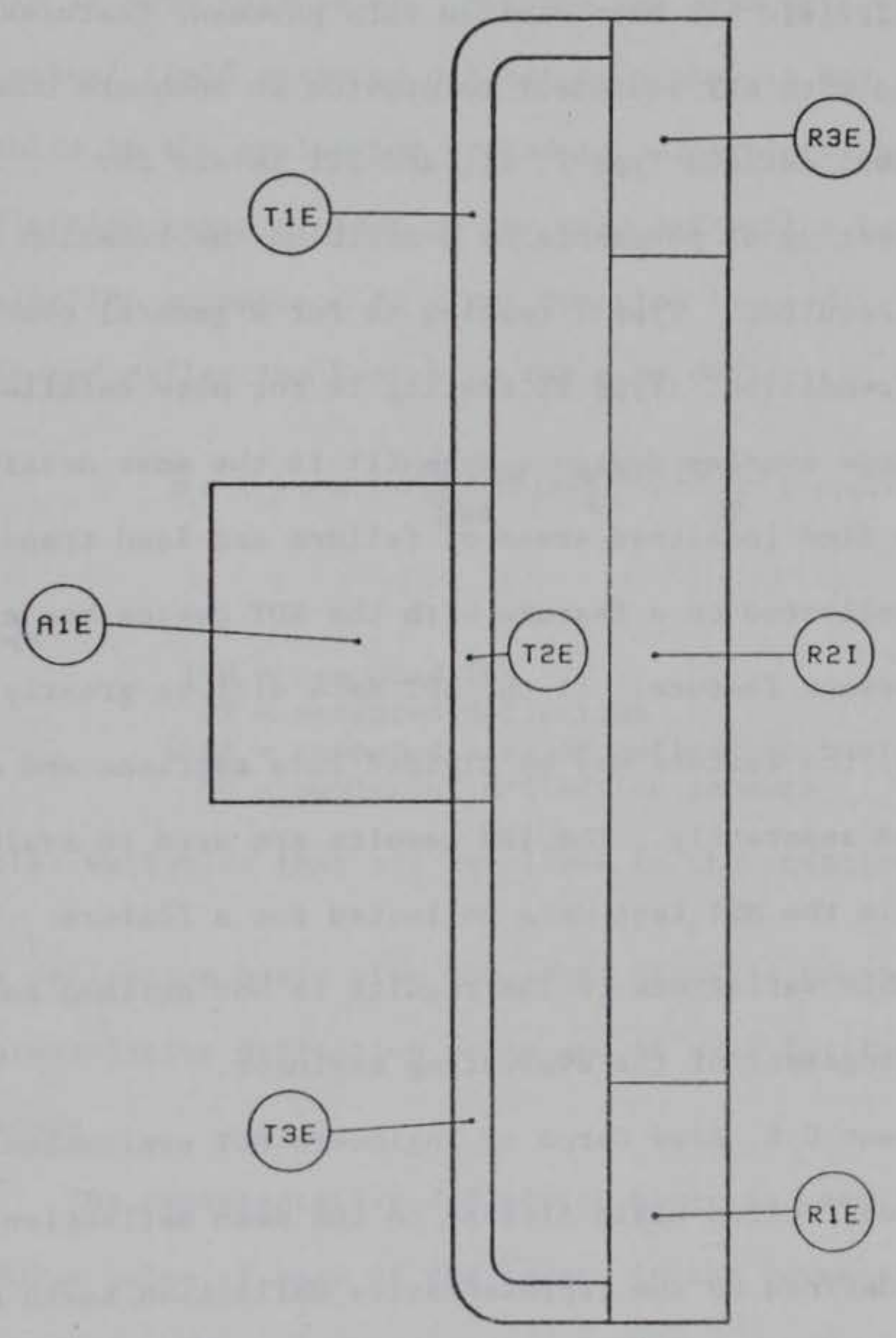

\footnotetext{
LEGEND

$\frac{\text { TYPE OF FEATURE }}{\text { R-RUNHAY }}$

T-TAXIHAY

A-PPRON

TYPE OF TRAFFIC

I-RUNWAY IHTERIOR

E-ALL FEATURES EXCEPT RUNLAY INTERIORS
}

Figure 3. Schematic of Airfield Pavement Divided into Features 
After an airfield has been divided into pavement features, each feature is tested with NDT equipment to provide an adequate number of tests. ASTM D 4695 defines Type I, II, and III levels for nondestructive testing of pavements by describing the location and number of tests required. Type I testing is for a general overview of the pavement condition. Type II testing is for more detailed analysis to include overlay design. Type III is the most detailed testing, used to find localized areas of failure and load transfer. The data collected on a feature with the NDT device are used to evaluate the pavement feature. If the NDT data differs greatly within a feature, the feature may be divided into sections and each section evaluated separately. The ISM results are used to evaluate the differences in the NDT test data collected for a feature. The range of acceptable variations in ISM results is not defined and is left up to the judgement of the evaluating engineer.

Under present U.S. Army Corps of Engineers NDT evaluation procedures, the deflection basin closest to the mean deflection basin of a feature is defined as the representative deflection basin and is used for evaluating the feature. To determine the representative deflection basin, initially each deflection basin is normalized to the same load to eliminate the effects of different loading. The load for each test varies slightly. After the deflection basins have been normalized, the area under the measured portion of each deflection basin is calculated. A mean deflection basin is then calculated by averaging the deflections at each sensor for all of the tests conducted on a feature. The area under the mean deflection 
basin is then calculated. Because the mean deflection basin is not an actual field measured deflection basin, it may give erroneous results in the evaluation procedure. Therefore the field measured deflection basin closest to the mean deflection basin is used for evaluation purposes. An error function is used to compare the measured deflection basins to the mean deflection basin.

$$
\text { ERROR }=\left(\frac{\overline{I S M}-I S M}{\overline{I S M}}\right)^{2}+\sum_{1}^{N D}\left(\frac{\overline{D F}-D F}{\overline{D F}}\right)^{2}+\left(\frac{\overline{A R E A}-A R E A}{\overline{A R E A}}\right)^{2}
$$

Where:

$$
\begin{aligned}
\text { ISM } & =\text { computed ISM } \\
\text { DF } & =\text { measured deflection } \\
\text { AREA } & =\text { computed area of deflection basin } \\
\text { ND } & =\text { number of deflection sensors }
\end{aligned}
$$

(Note: variables that are overlined in the equation indicate average)

The deflection basin with the least ERROR is considered the representative deflection basin and is used for the evaluation of the feature.

The representative deflection basin is used to determine the modulus value of each of the layers in the pavement system being evaluated. The computer program BISDEF determines a set of modulus values that provide the best fit between the measured deflection basin and a computed deflection basin when given an initial estimate of the elastic modulus values, a range of modulus values, and a set of measured deflections. The program BISDEF calculates a deflection basin based on the initial input data and then compares the calculated deflection basin to the measured deflection basin. BISDEF then varies the modulus values, within the specified limits, of each 
layer in the pavement system until the calculated deflection basin corresponds with the measured deflection basin.

The modulus values for each of the layers in the pavement system, coupled with the design traffic, are input into a computer program, AIRPAVE. For a particular aircraft, AIRPAVE uses the modulus values determined by BISDEF and computes stresses and strains that will occur in the pavement system. AIRPAVE then calculates limiting stress and strain values from empirical criteria. The ratio of the allowable stresses and strains to the calculated values is used to determine the allowable load of the design aircraft at the design pass level, the allowable passes of the design aircraft at the design load, and the overlay required for the pavement feature to sustain the design aircraft at the design pass and load level. The results of AIRPAVE are the final output from the NDT evaluation procedure. 
CHAPTER IV

DESCRIPTION OF FIELD TESTING PROGRAM

\section{Description of Field Sites}

The field sites selected for investigating the NDT evaluation procedure made up an array of airfield pavements. The array of pavements was selected to include rigid (portland cement concrete $(P C C))$, flexible (asphalt concrete $(A C)$ ), and composite (AC over PCC) pavements of two relative strengths provided by thick and thin sections as well as two types of subgrades, fine-grained and coarsegrained. The twelve sites were located at five airfields around the southeastern United States. Table 1 summarizes the location and structure of each site tested. Throughout the remainder of this study, the sites will be referred to by number as defined in Table 1 .

\section{Description of NDT Testing}

The performance of NDT tests at each site consisted of obtaining deflection basin measurements at sixteen locations. The NDT tests were performed just as they would be for a typical pavement evaluation. However, the NDT tests were run relatively close together to eliminate the possible need for dividing any of the pavement areas tested into sections. The testing procedure used at each site would be defined as Type II according to ASTM D 4695, with 
the tests being conducted closer together than required. Figure 4 shows the pattern of NDT testing that was used at each test site. The same testing pattern was used on $\mathrm{AC}$ and composite pavements.

Table 1.

Summary of Pavement Structures

\begin{tabular}{|c|c|c|c|c|c|}
\hline $\begin{array}{l}\text { Site } \\
\text { Number }\end{array}$ & $\begin{array}{c}\text { Site } \\
\text { Location }\end{array}$ & Surface & Base & Subbase & Subgrade \\
\hline 1 & $\begin{array}{c}\text { Brookley } \\
\text { Field, Alabama }\end{array}$ & $18^{\prime \prime} \mathrm{PCC}$ & $\ldots+\cdots$ & - n-n & $\begin{array}{l}\text { silty } \\
\text { sand }\end{array}$ \\
\hline 2 & $\begin{array}{l}\text { Pensacola } \\
\text { Naval Air } \\
\text { Station, } \\
\text { Florida }\end{array}$ & 10. PCC & $\begin{array}{c}4^{\prime \prime} \\
\text { 8ravel1y- } \\
\text { silty } \\
\text { sand }\end{array}$ & $\ldots$ & $\begin{array}{l}\text { silty } \\
\text { sand }\end{array}$ \\
\hline 3 & $\begin{array}{l}\text { Birmingham } \\
\text { Municipal } \\
\text { Airport, } \\
\text { Alabama }\end{array}$ & $7 " \mathrm{PCC}$ & $\ldots$ & $\ldots \ldots$ & $\begin{array}{l}\text { sandy } \\
\text { clay }\end{array}$ \\
\hline 4 & $\begin{array}{c}\text { Sheppard } \\
\text { Atr Force } \\
\text { Base, Texas }\end{array}$ & 21" PCC & $\begin{array}{c}6^{\prime \prime} \\
\text { gravelly- } \\
\text { silty sand }\end{array}$ & n..... & $\begin{array}{l}\text { clayey } \\
\text { s and }\end{array}$ \\
\hline 5 & $\begin{array}{l}\text { Pensacola } \\
\text { Naval A1r } \\
\text { Station, } \\
\text { Florida }\end{array}$ & $5.5^{*} \mathrm{AC}$ & $\begin{array}{l}13.5^{\prime \prime} \\
\text { graveliy- } \\
\text { silty sand }\end{array}$ & $\ldots+$. & silty sand \\
\hline 6 & $\begin{array}{c}\text { Sheppard } \\
\text { Air Force } \\
\text { Base, Texas }\end{array}$ & $7 " \mathrm{AC}$ & $\begin{array}{c}20^{*} \text { sandy- } \\
\text { silty } \\
\text { gravel } \\
\end{array}$ & $\ldots+\infty$ & sandy clay \\
\hline 7 & $\begin{array}{l}\text { Birmingham } \\
\text { Municipal } \\
\text { Airport, } \\
\text { Alabama }\end{array}$ & $4 " A C$ & $\begin{array}{c}\text { 4" sandy- } \\
\text { silty } \\
\text { gravel }\end{array}$ & $\begin{array}{c}28 " \\
\text { grave } 11 y- \\
\text { clayey sand }\end{array}$ & $\begin{array}{c}\text { sandy-clayey } \\
\text { gravel }\end{array}$ \\
\hline 8 & $\begin{array}{l}\text { Robins Air } \\
\text { Force } \\
\text { Base, Georgia }\end{array}$ & $8^{*} \mathrm{AC}$ & $\begin{array}{c}8^{\prime \prime} \text { sandy } \\
\text { gravel }\end{array}$ & 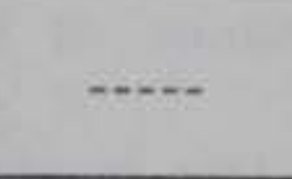 & $\begin{array}{l}\text { clayey } \\
\text { sand }\end{array}$ \\
\hline 9 & $\begin{array}{c}\text { Brookley } \\
\text { Field, Alabama }\end{array}$ & $\begin{array}{c}2 * \mathrm{AC} \\
\text { over } \\
10^{*} \mathrm{PCC}\end{array}$ & $\ldots .$. & 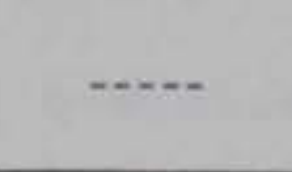 & $\begin{array}{c}\text { clayey-silty } \\
\text { sand }\end{array}$ \\
\hline 10 & $\begin{array}{l}\text { Birmingham } \\
\text { Municipal } \\
\text { Airport, } \\
\text { Al abama }\end{array}$ & $\begin{array}{l}6.5^{*} \mathrm{AC} \\
\text { over } \\
7^{*} \mathrm{PCC}\end{array}$ & $\ldots .$. & $\ldots$ & $\begin{array}{l}\text { grave } 11 y- \\
\text { sandy clay }\end{array}$ \\
\hline 11 & $\begin{array}{l}\text { Birmingham } \\
\text { Municipal } \\
\text { Airport. } \\
\text { Alabama }\end{array}$ & $\begin{array}{c}2^{*} \mathrm{AC} \\
\text { over } \\
7^{*} \mathrm{PCC}\end{array}$ & $\begin{array}{l}14^{\prime \prime} \mathrm{AC} \\
\text { treated }\end{array}$ & mon & sandy clay \\
\hline 12 & $\begin{array}{c}\text { Robins } \\
\text { Air Force } \\
\text { Base, Georgia }\end{array}$ & $\begin{array}{c}10^{*} \mathrm{AC} \\
\text { over } \\
7.5^{*} \mathrm{AC}\end{array}$ & $\cdots+\cdots$ & 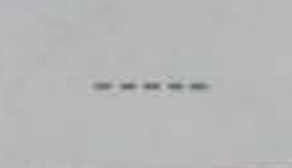 & clayey sand \\
\hline
\end{tabular}




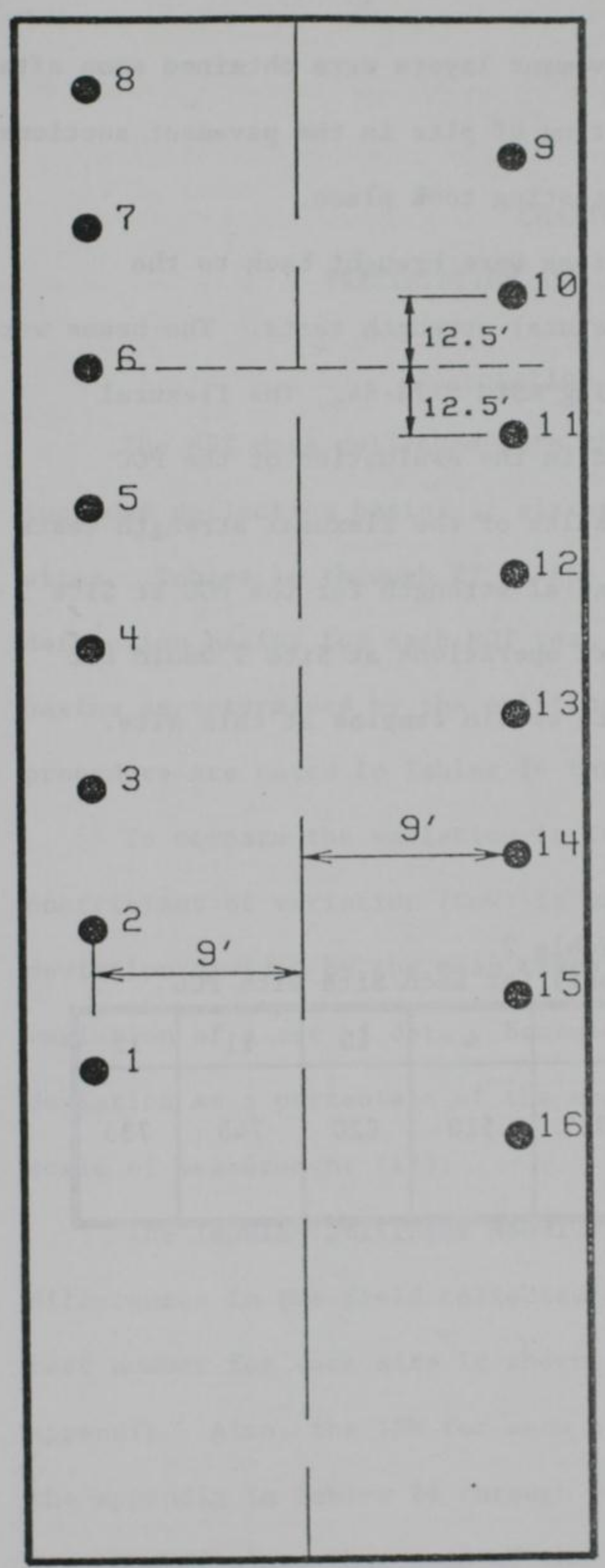

$\mathrm{AC}$ and Composite Pavements

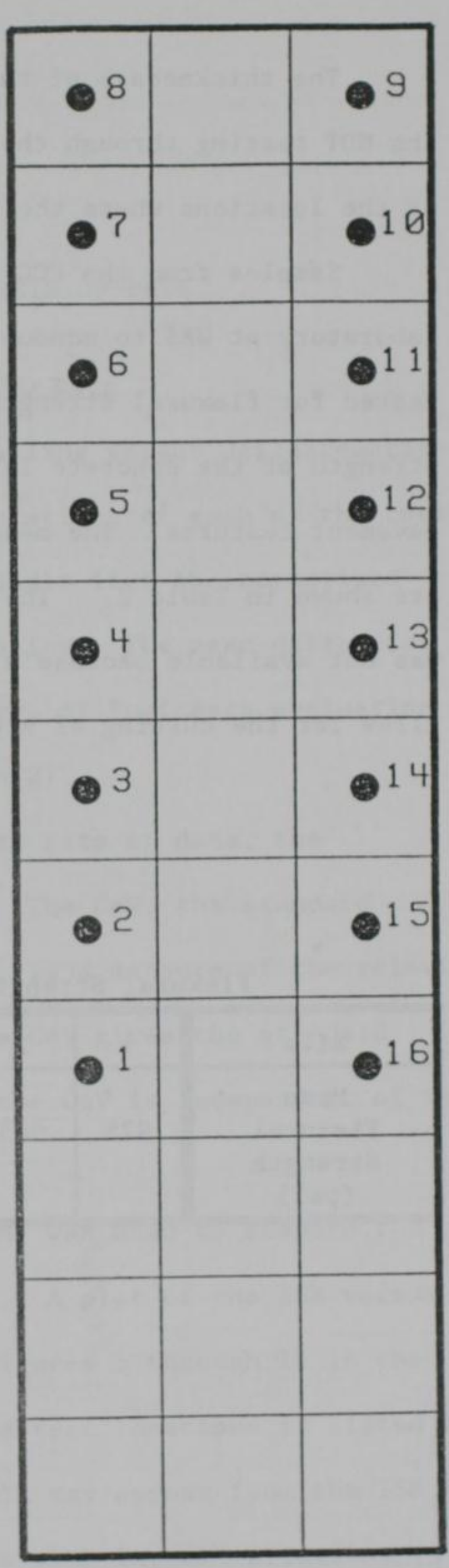

PCC Pavements

Figure 4. Layout of NDT Test Locations 
The thicknesses of the pavement layers were obtained soon after the NDT testing through the cutting of pits in the pavement sections at the locations where the NDT testing took place.

Samples from the PCC sections were brought back to the laboratory at WES to conduct flexural strength tests. The beams were tested for flexural strength using ASTM C-78-84. The flexural strength of the concrete is used in the evaluation of the PCC pavement features. The mean results of the flexural strength tests are shown in Table 2. The flexural strength for the PCC at Site 9 was not available because airport operations at Site 9 would not allow for the cutting of a pit to obtain samples at this site.

Table 2.

Flexural Strength (psi) for Each Site with PCC

\begin{tabular}{||c|c|c|c|c|c|c|c||}
\hline Site & 1 & 2 & 3 & 4 & 10 & 11 & 12 \\
\hline $\begin{array}{c}\text { Mean } \\
\text { Flexural } \\
\begin{array}{c}\text { Strength } \\
\text { (psi) }\end{array}\end{array}$ & 875 & 905 & 915 & 510 & 820 & 745 & 735 \\
\hline
\end{tabular}




\section{CHAPTER V \\ PRESENTATION AND ANALYSIS OF DATA}

\section{Presentation of FWD Data}

The NDT data collected with the falling weight deflectometer included deflection basins at sixteen locations at each of the twelve sites. Tables 16 through 27 in the appendix list the normalized deflection basins for each NDT test location. The mean deflection basins as determined by the existing Corps of Engineers evaluation procedure are noted in Tables 16 through 27.

To compare the variation in several sets of data, the coefficient of variation $(\mathrm{CoV})$ is used. The $\mathrm{CoV}$, the standard deviation divided by the mean times 100 , is a measure of the relative variation of a set of data. Because the CoV gives the standard deviation as a percentage of the mean, the $\mathrm{CoV}$ is independent of the scale of measurement (12).

The Impulse Stiffness Modulus (ISM) was used to compare the differences in the field collected data. A plot of the ISM versus test number for each site is shown in Figures 5 through 16 in the appendix. Also, the ISM for each of the test locations is listed in the appendix in Tables 28 through 30 . It may appear from the ISM vs Test Number plots that some of the sites with larger variations in ISM values should be divided into sections for evaluation purposes. 
However, inspection of the ISM plots coupled with the knowledge of the testing pattern precludes the sites from being divided into sections.

The average CoV for the sixteen ISM values for the twelve sites was 15.6 with values ranging from as low as 2.8 at Site 1 to 31.5 at Site 6. The average CoV for the PCC (Sites 1 through 4) was 13.0, for the AC (Sites 5 through 8 ) was 18.6, and for the composite pavements (Sites 9 through 12) was 15.1. A summary of the ISM results is shown in Table 3 .

Table 3 .

Summary of ISM (Kips/inch) Results

\begin{tabular}{||c|r|r|r||}
\hline Site & Mean (Kips/in) & Std Dev (Kips/in) & \multicolumn{1}{|c|}{ CoV8 } \\
\hline 1 & 6,205 & 175 & 2.8 \\
\hline 2 & 1,605 & 182 & 11.3 \\
\hline 3 & 1,402 & 376 & 26.8 \\
\hline 4 & 7,877 & 867 & 11.0 \\
\hline 5 & 486 & 30 & 6.2 \\
\hline 6 & 587 & 185 & 31.5 \\
\hline 7 & 431 & 84 & 19.5 \\
\hline 8 & 872 & 148 & 17.0 \\
\hline 9 & 1,938 & 238 & 12.3 \\
\hline 10 & 1,418 & 193 & 13.6 \\
\hline 11 & 1,604 & 468 & 29.2 \\
\hline 12 & 1,165 & 62 & 5.4 \\
\hline
\end{tabular}




\section{Presentation and Discussion of NDT}

Evaluation and Data

The data resulting from the analysis of the NDT data collected with the FWD include: modulus values for each layer of each pavement system; allowable gross load and allowable passes for a design aircraft each pavement can withstand; and the overlay required for each pavement to sustain a design aircraft at the design load for the design number of passes.

The computer program BISDEF was used to determine modulus values for each layer of each pavement system at each test point. Because the procedure of using BISDEF involves trial and error and engineering judgement, the mean deflection basin for each site, as noted in Tables 16 through 27 in the appendix, was used to determine limits and initial values for evaluating all of the basins at each site. As stated in Chapter III, the modulus of the AC can be determined from temperature data; or a design AC modulus, based on long-term temperature data, may be used for evaluating a feature. The third method for deteraining the $A C$ modulus is to calculate it based on the NDT data. For this study the BISDEF program was used to calculate the modulus value of all the layers in each pavement system analyzed, including the AC moduli. Figures 17 through 45 in the appendix show the modulus value versus test number for each layer of each pavement system. Tables 31 through 42 in the appendix 1 ist the modulus values calculated for all layers of each test at each site. It should be noted that the layers shown in Tables 31 through 42 may not agree with Table 1 , which shows the pavement structures at each 
site. The reason the measured thicknesses of each pavement layer do not necessarily correspond to the layers used in the evaluation is that when determining the modulus values of different pavement layers, layers with similar modulus values are modeled as one layer. A summary of the modulus values calculated for each layer at each site is shown in Table 4.

The CoV of the modulus values for each of the layers in each of the pavement systems had a wide range. The average CoV for the PCC at Sites 1 through 4 was 33; however, Site 1 and Site 4 had no variation in the PCC modulus because all the calculated values hit an upper limit. The average CoV for all of the PCC layers, Sites 1 through 4 and 9 through 12 , was 42 . The average $\mathrm{CoV}$ for the AC layer of Sites 5 through 8 was 51 . The average CoV for all AC layers, Sites 5 through 12, was 41 . The average $\mathrm{CoV}$ for the base course at all sites with a base course was 65 . The average CoV for the subgrade of all twelve sites was 21.

The computer program AIRPAVE was used to determine the allowable load-carrying capacities, allowable passes, and required overlay thicknesses for a particular aircraft. Since several of the sites consist of heavy duty pavements, 300,000 passes of a fully loaded ( 488,000 pounds) B-52 were used to evaluate the pavements tested for this investigation. The B-52 was chosen to ensure that a11 test locations at each sites would need an overlay. Nearly every test location did require an overlay, except at site 7 . Only one test location at Site 7 required an overlay. 
Table 4.

Summary of Modulus Values (psi).

\begin{tabular}{|c|c|c|c|c|}
\hline Site & Layer & Mean (psi) & Std Dev (psi) & Covz \\
\hline \multirow[t]{2}{*}{1} & $\mathrm{PCC}$ & $\cdots$ & $\cdots$ & $\ldots$ \\
\hline & SUBG & 20,448 & 982 & 5 \\
\hline \multirow[t]{2}{*}{2} & PCC & $3,725,671$ & 395,947 & 11 \\
\hline & SUBG & 11,554 & 1,976 & 17 \\
\hline \multirow[t]{2}{*}{3} & $\mathrm{PCC}$ & $4,227,854$ & $2,270,296$ & 54 \\
\hline & SUBG & 15,799 & 2,576 & 16 \\
\hline \multirow[t]{2}{*}{4} & PCC & $\ldots$ & $\ldots$ & $\ldots$ \\
\hline & SUBG & 24,233 & 4,590 & 19 \\
\hline \multirow[t]{3}{*}{5} & $\mathrm{AC}$ & 100,057 & 30,005 & 30 \\
\hline & BASE & 29,952 & 3,863 & 13 \\
\hline & SUBG & 20,646 & 2.326 & 11 \\
\hline \multirow[t]{3}{*}{6} & AC & 155,822 & 69,656 & 45 \\
\hline & BASE & 35,160 & 35,430 & 101 \\
\hline & SUBG & 17.278 & 2.460 & 14 \\
\hline \multirow[t]{3}{*}{7} & AC & 32,885 & 30,569 & 93 \\
\hline & BASE & 58,154 & 26,085 & 45 \\
\hline & SUBG & 70,021 & 16,733 & 24 \\
\hline \multirow[t]{3}{*}{8} & $A C$ & 234,317 & 84,617 & 36 \\
\hline & BASE & 13,951 & 3.061 & 22 \\
\hline & SUBG & 63,093 & 4.787 & 8 \\
\hline \multirow[t]{3}{*}{9} & $A C$ & $\cdots$ & $\cdots$ & $\ldots$ \\
\hline & PCC & $7,650,183$ & $1,398,976$ & 18 \\
\hline & SUBG & 17,034 & 1,269 & 7 \\
\hline \multirow[t]{3}{*}{10} & $A C$ & 246,025 & 68,202 & 28 \\
\hline & PCC & $2,157,801$ & $1,538,160$ & 71 \\
\hline & SUBG & 24,470 & 3,779 & 15 \\
\hline \multirow[t]{4}{*}{11} & $A C$ & $\cdots$ & $\cdots$ & $\ldots$ \\
\hline & PCC & $5,214,948$ & $3,093,400$ & 59 \\
\hline & BASE & 28,756 & 40,841 & 142 \\
\hline & SUBG & 52,450 & 47,349 & 90 \\
\hline \multirow[t]{3}{*}{12} & $A C$ & 104,522 & 13,586 & 13 \\
\hline & PCC & $5,210,524$ & $1,941,995$ & 37 \\
\hline & SUEG & 26,633 & 5,353 & 20 \\
\hline
\end{tabular}


For each site, all sixteen test locations were evaluated to determine the $\mathrm{AC}$ and unbonded PCC overlay requirements as shown in the appendix in Tables 43 through 54 and graphically shown in Figures 46 through 65 . A PCC overlay was not calculated for the AC pavements (Sites 5 through 8 ). For the Composite pavements (Sites 9 through 12), the AC surface was considered a bond breaker and an unbonded PCC overlay was calculated the same as for sites 1 through 4. A summary of the overlay results is shown in Table 5 .

The allowable gross load and allowable passes of the design aircraft were calculated for each test location at each site. The allowable gross load and allowable passes is shown in the appendix in Tables 55 through 60 and graphically in Figures 66 through 89. A summary of the allowable gross load and allowable passes is shown in Table 6 . 
Table 5.

Summary of Overlay (inches) Results

\begin{tabular}{|c|c|c|c|c|}
\hline Site & Overlay & Mean (in) & Std Dev (in) & $\mathrm{CoV}_{8}$ \\
\hline \multirow[t]{2}{*}{1} & AC & 4.8 & 0.7 & 13.8 \\
\hline & PCC & 12.8 & 0.3 & 2.6 \\
\hline \multirow[t]{2}{*}{2} & $\mathrm{AC}$ & 28.6 & 2.4 & 8.3 \\
\hline & PCC & 18.8 & 0.8 & 4.2 \\
\hline \multirow[t]{2}{*}{3} & $\mathrm{AC}$ & 32.8 & 4.1 & 12.6 \\
\hline & PCC & 18.6 & 1.7 & 9.2 \\
\hline \multirow[t]{2}{*}{4} & $\mathrm{AC}$ & 21.7 & 3.3 & 15.2 \\
\hline & PCC & 24.1 & 1.2 & 5.1 \\
\hline \multirow[t]{2}{*}{5} & $\mathrm{AC}$ & 13.2 & 1.6 & 12.0 \\
\hline & PCC & $\cdots$ & $\cdots$ & $\cdots$ \\
\hline \multirow[t]{2}{*}{6} & $\mathrm{AC}$ & 13.1 & 4.6 & 35.2 \\
\hline & PCC & $\cdots$ & - & $\cdots$ \\
\hline \multirow[t]{2}{*}{7} & $\mathrm{AC}$ & 1.6 & 4.2 & 400.0 \\
\hline & PCC & $\cdots$ & $\cdots$ & $\cdots$ \\
\hline \multirow[t]{2}{*}{8} & $\mathrm{AC}$ & 12.0 & 0.9 & 7.4 \\
\hline & PCC & $\cdots$ & $\cdots$ & $\cdots$ \\
\hline \multirow[t]{2}{*}{9} & $\mathrm{AC}$ & 30.1 & 2.2 & 7.2 \\
\hline & PCC & 20.8 & 0.9 & 4.3 \\
\hline \multirow[t]{2}{*}{10} & $\mathrm{AC}$ & 15.9 & 8.9 & 55.9 \\
\hline & PCC & 13.8 & 6.0 & 43.6 \\
\hline \multirow[t]{2}{*}{11} & $\mathrm{AC}$ & 28.9 & 7.1 & 24.4 \\
\hline & PCC & 21.2 & 3.1 & 14.9 \\
\hline \multirow[t]{2}{*}{12} & $\mathrm{AC}$ & 25.3 & 9.9 & 39.1 \\
\hline & PCC & 20.0 & 6.0 & 30.0 \\
\hline
\end{tabular}


Table 6.

Summary of Allowable Gross Load (AGL)

and Allowable Passes

\begin{tabular}{|r|r|r|r|r|r|r||}
\hline \multirow{2}{*}{ Site } & \multicolumn{3}{|c|}{$\begin{array}{c}\text { Allowable Gross Load } \\
\text { (Kips) }\end{array}$} & \multicolumn{1}{c||}{ Allowable Passes } \\
\cline { 2 - 7 } & \multicolumn{1}{|c|}{ Mean } & $\begin{array}{r}\text { Std } \\
\text { Dev }\end{array}$ & \multicolumn{1}{c|}{ CoV8 } & \multicolumn{1}{c|}{ Mean } & Std Dev & \multicolumn{1}{c||}{ CoV8 } \\
\hline 1 & 377 & 4.7 & 1.2 & 10,172 & 1,425 & 14.0 \\
\hline 2 & 186 & 8.6 & 4.6 & 30 & 8.6 & 28.3 \\
\hline 3 & 136 & 16.6 & 12.2 & 7.3 & 4.2 & 57.8 \\
\hline 4 & 277 & 13.5 & 4.9 & 511 & 184 & 35.9 \\
\hline 5 & 211 & 25.1 & 11.9 & 57 & 47.3 & 82.7 \\
\hline 6 & 224 & 112 & 50.3 & 251,670 & 999,556 & 397.2 \\
\hline 7 & 1,460 & 753 & 51.6 & $3.2 \times 10^{6}$ & $1.5 \times 10^{6}$ & 46.2 \\
\hline 8 & 171 & 14.0 & 8.2 & 1,705 & 657 & 38.5 \\
\hline 9 & 174 & 10.1 & 5.8 & 21.3 & 8.5 & 40.0 \\
\hline 10 & 324 & 167 & 51.7 & 288,726 & 993,772 & 344.2 \\
\hline 11 & 131 & 57.9 & 44.3 & 105 & 397 & 376.6 \\
\hline 12 & 197 & 59.8 & 30.3 & 250,207 & 999,945 & 399.6 \\
\hline
\end{tabular}

The average $\mathrm{CoV}$ for the $\mathrm{AC}$ overlays was 53 , and the average $\mathrm{CoV}$ for the PCC overlays was 14. The average CoV for the allowable gross loads was 23, and the average CoV for the allowable passes was 155 .

\section{Analysis and Discussion of Data}

Table 7 is a summary of the average CoV determined for each aspect of the evaluation. The ISM represents the data collected in the field. The modulus values represent the first step of the evaluation procedure. The overlay requirements, allowable gross load, and allowable passes represent the output from the evaluation. 
Table 7.

Summary of $\mathrm{CoV}$ Values

\begin{tabular}{|c|c|c|}
\hline \multicolumn{2}{|c|}{ Aspect of Evaluation } & Average $\mathrm{CoV}_{8}$ \\
\hline Field Data & ISM & 16 \\
\hline \multirow{4}{*}{$\begin{array}{l}\text { Determination of } \\
\text { Moduli }\end{array}$} & PCC Modulus & 42 \\
\hline & AC Modulus & 41 \\
\hline & Base Modulus & 65 \\
\hline & Subgrade Modulus & 20 \\
\hline \multirow{4}{*}{$\begin{array}{c}\text { Results } \\
\text { of } \\
\text { Evaluation }\end{array}$} & PCC Overlay & 14 \\
\hline & AC Overlay & 53 \\
\hline & Allowable Gross Load & 23 \\
\hline & Allowable Passes & 155 \\
\hline
\end{tabular}

From Table 7, it is apparent that the CoV was not consistent throughout the evaluation. Because the relationships for determining the moduli of each layer and for determining the results of the evaluation are not linear, it would not be expected that the CoV remain constant throughout the evaluation. Since the CoV was not constant throughout the evaluation procedure, the reliability level of a particular test would not be expected to remain constant throughout the evaluation.

For this study, the reliability level being investigated was 95 percent. However, any reliability level desired could have been used. A 95 percent reliability corresponds to being 95 percent confident that the entire pavement will perform to the desired level of service, or that 95 percent of the pavement will perform to the desired level of service. In order to determine a 95 percent 
reliability, the distribution of the data collected needs to be investigated. Because field data are being collected, it is assumed that the results will be normally distributed. The sample population that has been measured by the falling weight deflectometer may not have a strictly normal distribution; however, if an infinite number of tests were conducted, it would be expected that distribution would be normal. Since the data are assumed to have a normal distribution, a prediction interval can be determined using the " $t$ " distribution (14). The formula for finding the prediction interval follows:

$$
\mu_{n} \pm t_{\alpha} S \sqrt{1+\frac{1}{n}}
$$

where:

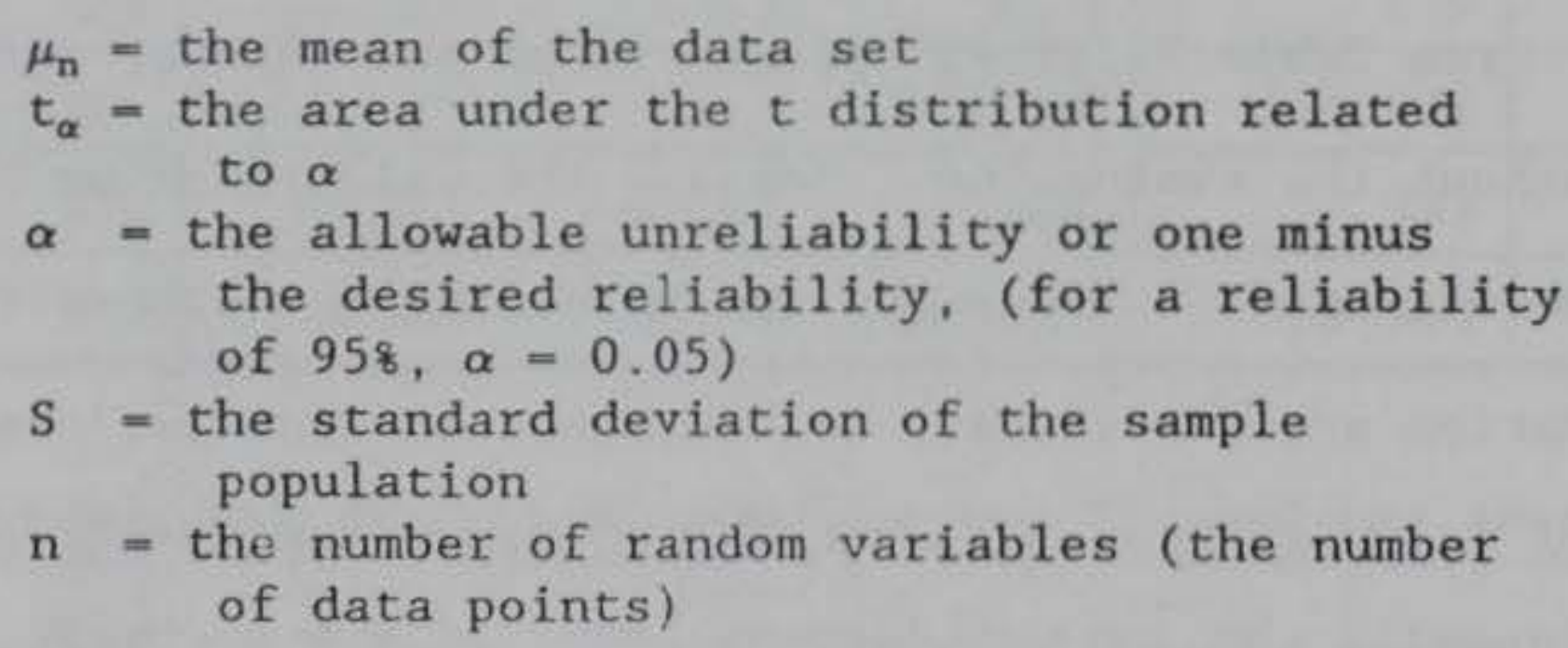

Equation 4 is for a one-sided test, although it shows the " \pm " sign. The "+" sign was used for the overlay results, and the " -" sign was used for all other aspects of the evaluation.

The values for $t_{\alpha}$ can be found in virtually any book with statistical tables (13). To obtain a reliability level other than 95 percent, the $t_{\alpha}$ is adjusted to the desired level of reliability. For a11 the data analyzed in this study there were 16 random variables 
which corresponds to $n-1$ or 15 degrees of freedom. The $t_{\alpha}$ for 95 percent reliability $\left(t_{.05}\right)$ with 15 degrees of freedom is, $t_{.05}=1.753$.

For all of the data calculated for this study and the results of the data analysis a 95 percent reliability level was determined. The following Tables ( 8 through 12) compare the results of the existing evaluation procedure with the mean of each step of the evaluation procedure and the 95 percent reliability level results. The mean of the existing evaluation procedure in the following tables lists the test number that was chosen by the existing evaluation procedure and the related result. Adjacent to the existing evaluation procedure is the test number closest to the mean of the respective data set with its corresponding value and the test number closest to the 95 percent reliability level and its corresponding value. 
Table 8 .

ISM (Kips/inch) Results Compared to Existing Evaluation Procedure

\begin{tabular}{||c|c|c|c|c|c|c||}
\hline \multirow{2}{*}{ Site } & \multicolumn{2}{|c|}{$\begin{array}{c}\text { Existing } \\
\text { Evaluation } \\
\text { Procedure }\end{array}$} & \multicolumn{4}{|c|}{$\begin{array}{c}\text { ISM } \\
\text { (Kips/In) } \\
\text { Results }\end{array}$} \\
\cline { 2 - 7 } & $\begin{array}{c}\text { Mean } \\
\text { Test }\end{array}$ & $\begin{array}{c}\text { ISM } \\
\text { (Kips/ } \\
\text { in) }\end{array}$ & $\begin{array}{c}\text { Mean } \\
\text { Test }\end{array}$ & $\begin{array}{c}\text { ISM } \\
\text { (Kips/ } \\
\text { in) }\end{array}$ & $\begin{array}{c}958 \\
\text { Test }\end{array}$ & $\begin{array}{c}\text { ISM } \\
\text { (Kips/ } \\
\text { in) }\end{array}$ \\
\hline 1 & 11 & 6,004 & 1 & 6,199 & 15 & 5,944 \\
\hline 2 & 14 & 1,598 & 14 & 1,598 & 2 & 1,086 \\
\hline 3 & 7 & 1,383 & 15 & 1,397 & 2 & 1,057 \\
\hline 4 & 7 & 8,256 & 7 & 8,256 & 11 & 6,355 \\
\hline 5 & 13 & 480 & 3 & 488 & 10 & 431 \\
\hline 6 & 13 & 533 & 8 & 580 & 9 & 330 \\
\hline 7 & 11 & 366 & 14 & 433 & 3 & 285 \\
\hline 8 & 8 & 936 & 15 & 866 & 16 & 687 \\
\hline 9 & 6 & 1,198 & 1 & 1,937 & 15 & 1,560 \\
\hline 10 & 15 & 1,097 & 14 & 1,424 & 10 & 1,097 \\
\hline 11 & 16 & 1,480 & 3 & 1,590 & 1 & 835 \\
\hline 12 & 4 & 1,107 & 10 & 1,170 & 1 & 1,035 \\
\hline \hline
\end{tabular}


Table 9.

AC Overlay (inches) Results Compared to Existing Evaluation Procedure

\begin{tabular}{||c|c|c|c|c|c|c||}
\hline \multirow{2}{*}{ Site } & \multicolumn{2}{|c|}{$\begin{array}{c}\text { Existing } \\
\text { Evaluation } \\
\text { Procedure }\end{array}$} & \multicolumn{5}{c||}{$\begin{array}{c}\text { AC } \\
\text { Overlay (in) } \\
\text { Results }\end{array}$} \\
\cline { 2 - 7 } & $\begin{array}{c}\text { Mean } \\
\text { Test }\end{array}$ & $\begin{array}{c}\text { AC } \\
\text { O/L } \\
\text { (in) }\end{array}$ & $\begin{array}{c}\text { Mean } \\
\text { Test }\end{array}$ & $\begin{array}{c}\text { AC } \\
\text { O/L } \\
\text { (in) }\end{array}$ & $\begin{array}{c}958 \\
\text { Test }\end{array}$ & $\begin{array}{c}\text { AC } \\
\text { (in) }\end{array}$ \\
\hline 1 & 11 & 4.9 & 6 & 4.8 & 15 & 5.9 \\
\hline 2 & 14 & 29.6 & 13 & 28.6 & 2 & 32.1 \\
\hline 3 & 7 & 32.3 & 3 & 33.0 & 5 & 39.8 \\
\hline 4 & 7 & 20.6 & 7 & 20.6 & 11 & 28.6 \\
\hline 5 & 13 & 15.6 & 5 & 13.1 & 11 & 15.7 \\
\hline 6 & 13 & 14.0 & 5 & 13.3 & 2 & 19.5 \\
\hline 7 & 11 & 0.0 & -- &.- & $\ldots$ & $\cdots$ \\
\hline 8 & 8 & 11.7 & 16 & 11.8 & 14 & 13.2 \\
\hline 9 & 6 & 29.1 & 4 & 29.9 & 13 & 33.4 \\
\hline 10 & 15 & 15.6 & 15 & 15.6 & 6 & 27.8 \\
\hline 11 & 16 & 33.1 & 1 & 28.6 & 7 & 40.8 \\
\hline 12 & 4 & 31.6 & 6 & 27.7 & 2 & 35.0 \\
\hline \hline
\end{tabular}


Table 10.

PCC Overlay (inches) Results Compared to Existing Evaluation Procedure

\begin{tabular}{|c|c|c|c|c|c|c|}
\hline \multirow[t]{2}{*}{ Site } & \multicolumn{2}{|c|}{$\begin{array}{l}\text { Existing } \\
\text { Evaluation } \\
\text { Procedure } \\
\end{array}$} & \multicolumn{4}{|c|}{$\begin{array}{c}\text { PCC } \\
\text { Overlay (in) } \\
\text { Results }\end{array}$} \\
\hline & $\begin{array}{l}\text { Mean } \\
\text { Test }\end{array}$ & $\begin{array}{l}\text { PCC } \\
0 / L \\
\text { (in) }\end{array}$ & $\begin{array}{l}\text { Mean } \\
\text { Test }\end{array}$ & $\begin{array}{l}\text { PCC } \\
0 / L \\
\text { (in) }\end{array}$ & $\begin{array}{l}958 \\
\text { Test }\end{array}$ & $\begin{array}{l}\text { PCC } \\
0 / L \\
\text { (in) }\end{array}$ \\
\hline 1 & 11 & 12.8 & 11 & 12.8 & 15 & 13.3 \\
\hline 2 & 14 & 19.2 & 13 & 18.8 & 12 & 19.9 \\
\hline 3 & 7 & 18.5 & 7 & 18.5 & 5 & 21.7 \\
\hline 4 & 7 & 23.7 & 7 & 23.7 & 11 & 26.6 \\
\hline 5 & 13 & - & $\cdots$ & $\cdots$ & $\cdots$ & $\cdots$ \\
\hline 6 & 13 & $\cdots$ & $\cdots$ & $\cdots$ & - & $\cdots$ \\
\hline 7 & 11 & $\cdots$ & $\cdots$ & $\cdots$ & .. & $\cdots$ \\
\hline 8 & 8 & $\cdots$ & - & - & - & - \\
\hline 9 & 6 & 20.4 & 4 & 20.9 & 13 & 22.1 \\
\hline 10 & 15 & 14.6 & 10 & 13.5 & 6 & 19.7 \\
\hline 11 & 16 & 21.2 & 9,16 & 21.2 & 5,15 & 24.5 \\
\hline 12 & 4 & 23.1 & 7 & 20.1 & 2 & 24.2 \\
\hline
\end{tabular}


Table 11.

Allowable Passes Results Compared to Existing Evaluation Procedure

\begin{tabular}{|c|c|c|c|c|c|c|}
\hline \multirow[t]{2}{*}{ Site } & \multicolumn{2}{|c|}{$\begin{array}{l}\text { Existing } \\
\text { Evaluation } \\
\text { Procedure }\end{array}$} & \multicolumn{4}{|c|}{$\begin{array}{c}\text { Allowable } \\
\text { Passes } \\
\text { Results }\end{array}$} \\
\hline & $\begin{array}{l}\text { Mean } \\
\text { Test }\end{array}$ & $\begin{array}{c}\text { Allowable } \\
\text { Passes }\end{array}$ & $\begin{array}{l}\text { Mean } \\
\text { Test }\end{array}$ & $\begin{array}{c}\text { Allowable } \\
\text { Passes }\end{array}$ & $\begin{array}{l}958 \\
\text { Test }\end{array}$ & $\begin{array}{c}\text { Allowable } \\
\text { Passes }\end{array}$ \\
\hline 1 & 11 & 9,889 & 6 & 10,098 & 3 & 7,556 \\
\hline 2 & 14 & 26 & 4,13 & 30 & 6,12 & 21 \\
\hline 3 & 7 & 6 & 2,15 & 7 & 5 & 3 \\
\hline 4 & 7 & 544 & 7 & 544 & 11 & 210 \\
\hline 5 & 13 & 69 & 8 & 58 & 10 & 19 \\
\hline 6 & 13 & 1,171 & 7 & 6,776 & 1 & 80 \\
\hline 7 & 11 & $4 \times 10^{6}$ & 6 & $2.8 \times 10^{6}$ & 3 & 494,245 \\
\hline 8 & 8 & 1,710 & 8 & 1,710 & 10 & 849 \\
\hline 9 & 6 & 23 & 12 & 21 & 13 & 13 \\
\hline 10 & 15 & 918 & 2 & 326,765 & 6 & 17 \\
\hline 11 & 16 & 4 & 11 & 33 & 5,15 & 1 \\
\hline 12 & 4 & 2,554 & 12 & 2,554 & 1,2 & 8 \\
\hline
\end{tabular}


Table 12.

Allowable Gross Load (Kips) Results Compared to Existing Evaluation Procedure

\begin{tabular}{|c|c|c|c|c|c|c|}
\hline \multirow[t]{2}{*}{ Site } & \multicolumn{2}{|c|}{$\begin{array}{l}\text { Existing } \\
\text { Evaluation } \\
\text { Procedure } \\
\end{array}$} & \multicolumn{4}{|c|}{$\begin{array}{c}\text { Allowable } \\
\text { Gross Load (Kips) } \\
\text { Results }\end{array}$} \\
\hline & $\begin{array}{l}\text { Mean } \\
\text { Test }\end{array}$ & $\begin{array}{c}\text { Allowable } \\
\text { Load } \\
\text { (Kips) }\end{array}$ & $\begin{array}{l}\text { Mean } \\
\text { Test }\end{array}$ & $\begin{array}{c}\text { A1lowable } \\
\text { Load } \\
\text { (Kips) }\end{array}$ & $\begin{array}{l}958 \\
\text { Test }\end{array}$ & $\begin{array}{c}\text { Allowable } \\
\text { Load } \\
\text { (Kips) }\end{array}$ \\
\hline 1 & 11 & 377 & 11 & 377 & 3 & 368 \\
\hline 2 & 14 & 182 & 4 & 188 & 6,12 & 175 \\
\hline 3 & 7 & 136 & 7 & 136 & 5 & 110 \\
\hline 4 & 7 & 282 & 7 & 282 & 11 & 251 \\
\hline 5 & 13 & 162 & 3 & 212 & 13 & 162 \\
\hline 6 & 13 & 185 & 7 & 229 & 2 & 129 \\
\hline 7 & 11 & 1,163 & 2 & 1,483 & 4 & 151 \\
\hline 8 & 8 & 173 & 8 & 173 & 10 & 151 \\
\hline 9 & 6 & 178 & 4 & 173 & 13 & 160 \\
\hline 10 & 15 & 299 & 15 & 299 & 6 & 169 \\
\hline 11 & 16 & 121 & 7 & 122 & 5 & 82 \\
\hline 12 & 4 & 156 & 7 & 198 & 1 & 145 \\
\hline
\end{tabular}


From Tables 8 through 12 comparing the results of each step of the evaluation procedure, it is apparent that there is no one field measured test point that will provide the mean or the 95 percent reliability of the results. Although some of the results were fairly consistent, only site 4 provided consistent results as shown in Table 13. Tables 13 and 14 summarize Tables 8 through 12 and show that the results are not definitive, and there does not exist a single field measured test that can be evaluated to provide a specified level of reliability.

Table 13.

Summary Comparison of Existing Evaluation Procedure Mean Test Number to Mean Test Number of Each Step of Evaluation Procedure

\begin{tabular}{||c|c|c|c|c|c|c||}
\hline \multirow{2}{*}{ Site } & \multicolumn{6}{|c|}{ Test Numbers Corresponding to Mean of Data Set } \\
\cline { 2 - 8 } & $\begin{array}{c}\text { Exist } \\
\text { Eval }\end{array}$ & AC O/L & PCC 0/L & AGL & $\begin{array}{c}\text { Allow } \\
\text { Passes }\end{array}$ & ISM \\
\hline 1 & 11 & 6 & 6,11 & 11 & 6 & 1 \\
\hline 2 & 14 & 13 & 13 & 4 & 4,13 & 14 \\
\hline 3 & 7 & 3 & 7 & 7 & 2,15 & 15 \\
\hline 4 & 7 & 7 & 7 & 7 & 7 & 7 \\
\hline 5 & 13 & 5 & $\ldots$ & 3 & 8 & 3 \\
\hline 6 & 13 & 5 & $\ldots$ & 7 & 7 & 8 \\
\hline 7 & 11 & $\ldots$ & $\ldots$ & 2 & 6 & 14 \\
\hline 8 & 8 & 16 & $\ldots$ & 8 & 8 & 15 \\
\hline 9 & 6 & 4 & 4,12 & 4 & 12 & 1 \\
\hline 10 & 15 & 3,15 & 10 & 15 & 2 & 14 \\
\hline 11 & 16 & 1 & 9,16 & 7 & 11 & 3 \\
\hline 12 & 4 & 6 & 7 & 7 & 12 & 10 \\
\hline
\end{tabular}


Table 14.

Summary Comparison of 958 Reliability Test Number at Each Step of Evaluation Procedure

\begin{tabular}{||c|c|c|c|c|c||}
\hline \multirow{2}{*}{ Site } & \multicolumn{6}{|c|}{ Test Numbers Corresponding to 958 Reliability of Data } \\
\cline { 2 - 6 } & SC O/L & PCC O/L & AGL & $\begin{array}{c}\text { Allow } \\
\text { Passes }\end{array}$ & ISM \\
\hline 1 & 15 & 15 & 3 & 3 & 15 \\
\hline 2 & 2 & 12 & 6,12 & 6,12 & 2 \\
\hline 3 & 5 & 5 & 5 & 5 & 2 \\
\hline 4 & 11 & 11 & 11 & 11 & 11 \\
\hline 5 & 11 & - & 13 & 10 & 10 \\
\hline 6 & 2 & - & 2 & 1 & 9 \\
\hline 7 & $\cdots$ & - & 4 & 3 & 3 \\
\hline 8 & 14 & $\ldots$ & 10 & 10 & 16 \\
\hline 9 & 13 & 13 & 13 & 13 & 15 \\
\hline 10 & 6 & 6 & 6 & 6 & 10 \\
\hline 11 & 7 & 5,15 & 5 & 5,15 & 1 \\
\hline 12 & 2 & 2 & 1 & 1,2 & 1 \\
\hline
\end{tabular}




\section{CHAPTER VI}

\section{DEVELOPMENT OF RELIABILITY-BASED PROCEDURE FOR \\ EVALUATING A PAVEMENT FEATURE}

The purpose of this investigation was to determine the reliability, in terms of the results, of using the mean deflection basin for evaluating a pavement feature. Also, a method was to be developed for determining the field measured NDT test that would provide a user-defined level of reliability in the NDT evaluation of a pavement feature. The data presented in Chapter $\mathrm{V}$ show that the mean deflection basin does not provide a consistent level of reliability in the results of the evaluation procedure. Therefore, a field measured NDT test that will provide the desired level of reliability for all aspects of the pavement evaluation does not exist. Because the use of a field measured test determined at a specified reliability level does not consistently correspond with the same reliability level in the results, a different approach must be used for evaluating a pavement feature at a user-defined level of reliability.

Since the results of the evaluation are of primary importance, the results of the evaluation should be used for determining the reliability of the pavement evaluation. The requirement of using the 
results of the NDT evaluation procedure to determine the reliability will necessitate that all NDT tests conducted for the evaluation of a feature be analyzed. This will increase the amount of computer and engineering time required to evaluate a pavement feature. However, to obtain the desired level of reliability, the analysis of additional data is justified. The additional computer and engineering time are particularly justified when compared to the multi-million dollar costs of major pavement construction and rehabilitation projects.

\section{Discussion of Evaluation Procedure}

The procedure for evaluating a pavement feature to determine results at a user-defined reliability level should be approximately the same as the present procedure with the exception that all NDT data collected be analyzed. The mean deflection basin of a feature should be determined. The initial modulus values and limits for each layer of the pavement system should be calculated based on the mean deflection basin of the feature being evaluated. The limits and initial modulus values determined for the mean deflection basin should then be used to determine the modulus values of each layer of the pavement system for each NDT test conducted on the feature. The reason for using the mean deflection basin to establish initial modulus values and limits is that if each NDT location was input to BISDEF and evaluated on its own, the amount of time required to evaliate a pavement feature would be tremendous. Experience has shown that once initial values and limits have been found, most 
modulus values calculated for that feature will fall within the limits. Alexander (1) can be used to determine ranges and initial limits.

Once the modulus values for the pavement layers at each NDT location of a feature have been determined, the evaluation using AIRPAVE can be accomplished. A design aircraft at a design load and pass level is determined. The design aircraft along with the modulus values are used to determine the allowable loads, passes, and overlays required at each NDT test location.

The mean and standard deviation of the results from AIRPAVE along with the " $t$ " distribution should be used to determine a userdefined level of reliability for the evaluation. It has been shown in Chapter $\mathrm{V}$ through the $\mathrm{CoV}$ that the range of distributions of each aspect of the results is not the same. Therefore, one set of results should be used to determine the level of reliability desired.

The required overlay results should not be used for determining the reliability of the evaluation. Although the distributions are assumed to be normal, the overlay results could be skewed. The reason the overlay results could be skewed is that if there is not a requirement of an overlay, the results do not indicate the degree of conservatism. If the thickness of the existing pavement is greater than required to support the design traffic, the evaluation procedure does not indicate the necessary thickness. In the analysis of data in the previous chapters, a large aircraft with a large number of passes was used for the evaluation to ensure that overlays were required for nearly every NDT test location evaluated. The 
requirement of overlays at virtually every NDT test location provided adequate results to assume a normal distribution. However, for most evaluations, not all NDT tests require an overlay, in fact a great many tests would not be expected to require an overlay. Therefore, if a significant number of NDT tests did not require an overly, a normal distribution could not be assumed and the " $t$ " distribution could not be used for analyzing the overlay results.

The number of allowable passes is also not an appropriate result to determine the reliability level of the evaluation procedure. AIRPAVE calculates the allowable passes, whether the allowable passes is less than or more than the design pass level. However, the allowable passes is very sensitive to the pavement structure. Once a pavement is structurally capable of supporting an aircraft for one pass, a slight increase in strength makes it capable of supporting many passes. The reason the number of allowable passes rises at such a rapid rate after the structure is adequate to support the aircraft is that the failure mode changes from a bearing or loadrelated failure to a fatigue failure. The change in failure modes results in a large increase in allowable passes with a small increase in pavement structure. Slight differences in the pavement structure of a feature may result in large variations in the number of allowable passes calculated at each NDT test location. The large variation in allowable passes cause the CoV to be very large, making the allowable passes a less desirable result to use for determining the reliability of the evaluation.

The most appropriate result for determining the reliability of 
a pavement feature is the allowable gross load. The allowable gross load is calculated whether it is below or above the input design level, and it is not as sensitive to the pavement structure as the allowable passes. The average CoV of the allowable gross load was smaller than the $\mathrm{CoV}$ for the allowable passes and the total $\mathrm{CoV}$ for the overlay requirements. The relatively small $\mathrm{CoV}$ indicates that the allowable gross load data are the most closely grouped set of results.

The comparison of the 95 percent reliability of the results by test number is shown in Table 14 in Chapter $v$. Table 15 lists the overlay results determined for each of the test numbers shown in Table 14. The results for site 7 were omitted because only one test point required an overlay. Although all data were included in all the evaluations for this study, the NDT data at site 7 that was significantly different would have been thrown out as an outlier in an actual pavement evaluation. Hall (11) can be used to determine outliers. Because the overlays in Table 15 are the overlays calculated for a particular NDT test, the results shown in Table 15 are not strictly the 95 percent reliability results. The results in Table 15 are the results calculated for the NDT test closest to the 95 percent results. 
Table 15.

958 Reliability Overlay Results

\begin{tabular}{|c|c|c|c|c|c|c|}
\hline \multirow{3}{*}{ Site } & \multicolumn{6}{|c|}{ for 958} \\
\hline & \multirow{2}{*}{$\begin{array}{c}\mathrm{AC} \\
\text { (in) }\end{array}$} & \multirow{2}{*}{$\begin{array}{c}\text { PCC } \\
\text { (in) }\end{array}$} & \multicolumn{2}{|c|}{ AGL } & \multicolumn{2}{|c|}{ Allow Passes } \\
\hline & & & $\begin{array}{c}\mathrm{AC} \\
\text { (in) }\end{array}$ & $\begin{array}{c}\text { PCC } \\
\text { (in) }\end{array}$ & $\begin{array}{c}\mathrm{AC} \\
\text { (in) }\end{array}$ & $\begin{array}{l}\text { PCC } \\
\text { (in) }\end{array}$ \\
\hline 1 & 5.9 & 13.3 & 6.2 & 13.4 & 6.2 & 13.4 \\
\hline 2 & 32.1 & 19.9 & 31.7 & 19.9 & 31.7 & 19.9 \\
\hline 3 & 39.8 & 21.7 & 39.8 & 21.7 & 39.8 & 21.7 \\
\hline 4 & 28.6 & 26.6 & 28.6 & 26.6 & 28.6 & 26.6 \\
\hline 5 & 15.7 & $\cdots$ & 15.6 & - & 15.2 & $\cdots$ \\
\hline 6 & 19.5 & $\cdots$ & 19.5 & . & 19.4 & $\ldots$ \\
\hline 7 & $\ldots$ & .. & $\cdots$ & $\cdots$ & -. & - \\
\hline 8 & 13.2 & - & 12.9 & -. & 12.9 & -. \\
\hline 9 & 33.4 & 22.1 & 33.4 & 22.1 & 33.44 & 22.1 \\
\hline 10 & 27.8 & 19.7 & 27.8 & 19.7 & 27.8 & 19.7 \\
\hline 11 & 40.8 & 24.5 & 27.8 & 24.5 & 27.8 & 24.5 \\
\hline 12 & 35.0 & 24.2 & 34.8 & 24.1 & 35.0 & 24.2 \\
\hline
\end{tabular}

It is very likely that there is not a test directly associated with the 95 percent reliability of the evaluation procedure. If the allowable gross load determined to have a 95 percent reliability for the evaluation of a feature falls between two tests, the following equation may be used for approximating the overlay that would correspond to the 95 percent reliability overlay requirement:

$$
O L_{958}=\frac{\left(A G L_{958}-A G L_{L L}\right) O L_{L L}+\left(A G L_{U L}-A G L_{958}\right) O L_{U L}}{\left(A G L_{958}-A G L_{L L}\right)+\left(A G L_{U L}-A G L_{958}\right)}
$$


Where:

$$
\begin{aligned}
& \mathrm{OL}_{95 z}=\text { The overlay associated with a } 558 \text { reliability } \\
& \mathrm{AGL}_{95 z} \text { - The allowable gross load deternined to have a } 958 \\
& \text { reliability level } \\
& \mathrm{AGL}_{L L}=\text { The allowable gross load associated with the NDT } \\
& \text { test less than and closest to the } \mathrm{AGL}_{952} \\
& \text { AGL } L_{\text {VL }}=\text { The allowable gross load associated with the NDT } \\
& \text { test greater than and closest to the } \mathrm{AGL}_{95 z} \\
& \mathrm{OL}_{2 L}=\text { The overlay associated with the } \mathrm{AGL}_{1 \mathrm{~L}} \\
& \text { OLVL = The overlay associated with the AGLUL }
\end{aligned}
$$

When there is a relatively small number of NDT tests conducted

on a feature, the value for the allowable gross load with a 95

percent reliability would be expected to be outside of the range of

the results. There are two options at this point. The first option

would be to use the results associated with the test that provided

the least allowable gross load. This option does not necessarily

provide a 95 percent reliability; however, from experience with

pavement evaluations, this would provide an adequate overlay. This

was the procedure used and reported in this study. The second option is to estimate the overlay that would be required to provide a 95

percent reliability with the following equation:

$$
O L_{958}=\left(\frac{O L_{L L}-O L_{L L-1}}{A G L_{L L}-A G L_{L L-1}}\right)\left(A G L_{958}-A G L_{L L}\right)+O L_{L L}
$$

(Note: The terms in equation (6) are the same as those in equation (5) with the addition of the terms with the subscript LL- 1 . The LL-1 subscript refers to the results associated with the test closest to the test defined as the LL.)

\section{Reliability-Based Evaluation Procedure}

In summary, the following procedure, should be used for determining a reliability-based evaluation of an airfield pavement 
feature: (1) analysis of the raw NDT data as presently done to determine the mean deflection basin; (2) evaluation of the mean deflection basin to determine modulus values and limits for each layer of the pavement system (using BISDEF); (3) determination of modulus values for each layer of the pavement system from the deflection basins measured at each NDT test location using the limits and initial values determined by the evaluation of the mean deflection basin (using BISDEF); (4) evaluation of the pavement system defined at each NDT location to determine allowable passes, allowable gross loads, and overlay requirements for the design aircraft (using AIRPAVE); (5) determination of the mean and standard deviation of the evaluation results for the allowable gross load; (6) use of the " $t$ " distribution to determine the desired level of reliability for the evaluation results; (7) determination of the overlay with equation 5 or 6 as appropriate that provides the userdefined level of reliability; (8) report the overlay calculated and the reliability level associated with the overlay requirement.

If the data analysis reveals that the desired reliability level would require results outside the bounds of the analyzed data, the overlay calculated for the NDT test with the least allowable gross load may be reported as the required overlay. It must be noted with the results that the evaluation from the NDT test providing the least allowable gross load are being reported. 
CHAPTER VII

SUMMARY, CONCLUSIONS, AND RECOMMENDATIONS

\section{$\underline{\text { Summary }}$ \\ Nondestructive pavement testing and data analysis were} conducted to determine the reliability of using the mean deflection basin for evaluating a pavement feature and to determine a reliability-based procedure for evaluating a pavement feature. Data for this investigation were obtained through field testing, which consisted of NDT performed at twelve sites around the southeastern United States. Three types of pavenents were tested: flexible (AC), rigid ( $P C C)$, and composite ( $A C$ over $P C C$ ). Sixteen NDT tests were conducted at each of the twelve sites.

For each site, the sixteen NDT tests were evaluated to determine the ISM, modulus values for each layer of each pavement system, allowable passes, allowable loads, and overlay requirements for a design aircraft. The data compiled for each aspect of the evaluation at each site was assumed to have a normal distribution. A CoV was determined for each data set so the variability between data sets could be compared. The " $t$ " distribution was used to determine the test number associated with a 95 percent reliability level for each phase of the evaluation. The results of each phase were compared to the results of the other phases. The comparisons of the 
phases of the evaluation were performed to determine if a particular field measured test would consistently provide results at the desired level of reliability.

\section{Conclusions}

The present method of evaluating a pavement feature based on the mean NDT test does not provide a consistent level of reliability in the NDT evaluation procedure.

The data analysis revealed that there was not a particular field test that provided the same level of reliability for each phase of the evaluation procedure. Since there is not a particular fieldtest that provides a consistent level of reliability throughout the evaluation procedure, there cannot be a means of determining a field measured test for evaluating a pavement feature at a specified level of reliability.

The evaluation of all the NDT tests conducted on a pavement feature provide sufficient data to perform a reliability analysis on the results. The allowable gross load results have the smallest CoV and provide useable results whether the pavement is under- or overdesigned. The allowable gross load results can be used for performing a reliability analysis of the NDT evaluation of a pavement feature.

\section{Recommendations}

Based on the conclusions derived from this field investigation and data analysis the following recommendations are made: (1) The 
present method of evaluating a pavement feature with the mean NDT should be discontinued; (2) All the NDT data collected for a pavement feature should be analyzed to provide layer moduli for each layer of the pavement system, allowable passes and allowable loads for the design aircraft, and the overlays required to support the design aircraft at the design load and pass level; (For features with less than 30 NDT data points, all NDT data should be analyzed. For features with 30 or more NDT data points, a minimum of 30 NDT data points should be analyzed.); (3) The allowable gross load results of the NDT procedure should be used to determine a mean and a standard deviation of the sample population; (4) The mean and the standard deviation of the allowable gross load results should be used in conjunction with the " $t$ " distribution to determine the allowable gross load associated with the desired level of reliability; (5) The overlay associated with the desired level of reliability should be determined as discussed in Chapter VI; (6) The overlay determined should be considered the overlay required to provide the desired level of reliability for the NDT evaluation procedure. 
1. Alexander, D.R., Kohn, S.D., and Grogan, W.P., (1989, Novmeber). "Nondestructive Testing Techniques and Evaluation Procedures for Airfield Pavements," First International Symposium on Nondestructive Testing of Pavements and Backcalculation of Moduli. ASTM Special Technical Publication; 1026.

2. American Society of Testing and Materials. (1990). "Standard Guide for General Pavement Deflection Measurements," Designation: D 4695-87, Annual Book of ASTM Standards, Volume 04.03, Philidelphia, $\mathrm{Pa}$.

3. Barber, V.C., Odom, E.C., and Patrick, R.W., (1978, July). "The Deterioration and Reliability of Pavements," U.S. Army Engineer Waterways Experiment Station, Vicksburg, Ms.

4. Bush, A.J., (1980, November). "Nondestructive Testing for Light Aircraft Pavements, Phase II," U.S. Army Engineer Waterways Experiment Station, Vicksburg, Ms.

5. Bentsen, R.A., Bush, A.J., and Harrison, J.A., (1989, January). "Evaluation of Nondestructve Equipment for Airfield Pavements," U.S. Army Engineer Waterways Experiment Station, Vicksburg, Ms.

6. Chou, Y.T., (1986, August). "Probabilistic and Reliability Analysis of the California Bearing Ratio (CBR) Design Method for Flexible Pavements," U.S. Army Engineer Waterways Experiment Station, Vicksburg, Ms.

7. Chou, Y.T., (1987, September). "Probabilistic and Reliability Design Procedures for Flexible Airfield Pavements - Elastic Layered Method," U.S. Army Engineer Waterways Experiment Station, Vicksburg, Ms.

8. Coleman, H.W., and Steele, W.G., (1989). Experimentation and Uncertainty Analysis. New York: John Wiley and Sons.

9. Green, J.L., and Hal1, J.W., Jr., (1975, September). "Nondestructive Vibratory Testing of Airport Pavements, Volume I," U.S. Department of Transportation, Report No. FAA-RD-73-205-I.

10. Hall, J,W., Jr., (1978, July). "Nondestructive Evaluation Procedure For Military Airfields," U.S. Army Engineer Waterways Experiment Station, Vicksburg, Ms. 
11. Hall, J.W., Jr., (1989, May). "Use of Statistical Methods to Analyse FWD Data," Civil Engineering Department, Auburn University, Auburn, Al.

12. Harr, M.E., (1977). Mechanics of Particulate Matter. New York: McGraw-Hill.

13. Miller, I., and Freund, J.E., (1977). Probability and Statistics for Engineers (2nd ed.). New York: Prentice-Hall.

14. Scheaffer, R.L., and McClave, J.T., (1986). Probability and Statistics for Engineers (2nd ed.). Boston: PWS Publishers.

15. Shahin, M.Y., and Kohn, S.D., (1981, October). "Pavement Maintenance Management for Roads and Parking Lots," U.S. Army Construction Engineering Research Laboratory," Champaign, Il.

16. Witczak, M.W., Uzan, J., and Johnson, M., (1983, December). "Development of Probabilistic Rigid Pavement Design Methodolgies for Military Airfields," U.S. Army Engineer Waterways Experiment Station, Vicksburg, Ms.

17. Yoder, E.J., and Witczak, M.W., (1975). Principles of Pavement Design (2nd ed.). New York: John Wiley and Sons. 
APPENDIX A

SUPPLEMENTARY TABLES AND FIGURES

Table 16.

Site 1, Normalized Deflection Basins

\begin{tabular}{|c|c|c|c|c|c|c|c|}
\hline \multirow{2}{*}{$\begin{array}{l}\text { Test } \\
\text { Number } \\
\text { (* Mean) }\end{array}$} & \multicolumn{7}{|c|}{$\begin{array}{l}\text { Distance from Load, (in) } \\
\text { (Deflection, mils) }\end{array}$} \\
\hline & 0 & 12 & 24 & 36 & 48 & 60 & 72 \\
\hline 1 & 4.1 & 3.8 & 3.7 & 3.1 & 3.2 & 2.5 & 2.9 \\
\hline 2 & 4.3 & 3.8 & 4.0 & 3.3 & 3.4 & 2.8 & 3.2 \\
\hline 3 & 4.2 & 3.9 & 3.8 & 3.5 & 3.9 & 2.9 & 3.4 \\
\hline 4 & 4.1 & 3.5 & 3.9 & 3.4 & 3.2 & 2.9 & 2.8 \\
\hline 5 & 4.0 & 3.6 & 3.7 & 3.1 & 3.3 & 2.7 & 3.1 \\
\hline 6 & 3.9 & 3.6 & 3.7 & 3.2 & 3.3 & 2.8 & 3.4 \\
\hline 7 & 4.0 & 3.6 & 3.6 & 3.3 & 3.3 & 2.7 & 3.0 \\
\hline 8 & 4.1 & 3.6 & 3.6 & 3.2 & 3.2 & 2.6 & 3.0 \\
\hline 9 & 4.1 & 3.6 & 3.7 & 3.2 & 3.1 & 3.0 & 3.2 \\
\hline 10 & 4.1 & 3.5 & 3.6 & 3.1 & 3.3 & 2.7 & 3.0 \\
\hline $11 *$ & 4.3 & 3.8 & 3.7 & 3.2 & 3.3 & 2.7 & 3.2 \\
\hline 12 & 4.2 & 3.8 & 3.7 & 3.1 & 3.3 & 3.0 & 3.4 \\
\hline 13 & 4.1 & 3.6 & 3.5 & 3.1 & 3.4 & 2.8 & 3.3 \\
\hline 14 & 4.1 & 3.6 & 3.8 & 3.3 & 3.5 & 2.9 & 3.1 \\
\hline 15 & 4.3 & 4.1 & 3.9 & 3.5 & 3.5 & 2.7 & 3.3 \\
\hline 16 & 4.2 & 3.7 & 3.9 & 3.0 & 3.3 & 3.0 & 3.1 \\
\hline
\end{tabular}


Table 17.

Site 2, Normalized Deflection Basins

\begin{tabular}{|c|c|c|c|c|c|c|c|}
\hline \multirow{2}{*}{$\begin{array}{c}\text { Test } \\
\text { Number } \\
\text { (* Mean) }\end{array}$} & \multicolumn{7}{|c|}{$\begin{array}{l}\text { Distance from Load, (in) } \\
\text { (Deflection, mils) }\end{array}$} \\
\hline & 0 & 12 & 24 & 36 & 48 & 60 & 72 \\
\hline 1 & 15.4 & 14.5 & 13.3 & 11.4 & 9.7 & 7.7 & 6.0 \\
\hline 2 & 23.4 & 22.5 & 21.0 & 18.2 & 15.0 & 12.0 & 9.3 \\
\hline 3 & 16.3 & 15.3 & 14.1 & 12.0 & 10.0 & 7.8 & 5.8 \\
\hline 4 & 15.3 & 14.0 & 12.8 & 10.7 & 9.0 & 7.0 & 5.6 \\
\hline 5 & 14.5 & 13.4 & 12.1 & 10.3 & 8.7 & 6.8 & 5.6 \\
\hline 6 & 17.2 & 16.1 & 14.9 & 12.7 & 10.9 & 8.7 & 6.8 \\
\hline 7 & 13.5 & 12.5 & 11.1 & 9.1 & 7.6 & 5.7 & 4.4 \\
\hline 8 & 13.9 & 12.7 & 11.5 & 9.6 & 8.0 & 6.3 & 4.8 \\
\hline 9 & 16.6 & 15.4 & 13.8 & 11.8 & 9.8 & 7.7 & 5.9 \\
\hline 10 & 14.2 & 13.4 & 11.8 & 10.0 & 8.2 & 6.3 & 4.8 \\
\hline 11 & 15.7 & 14.8 & 13.3 & 11.1 & 9.4 & 7.4 & 5.7 \\
\hline 12 & 16.7 & 16.2 & 14.9 & 12.9 & 11.0 & 8.8 & 6.7 \\
\hline 13 & 16.6 & 15.6 & 14.1 & 11.9 & 10.1 & 7.9 & 6.1 \\
\hline $14 *$ & 15.9 & 15.0 & 13.4 & 11.3 & 9.7 & 7.5 & 6.1 \\
\hline 15 & 15.4 & 14.4 & 13.1 & 11.3 & 9.5 & 7.5 & 5.9 \\
\hline 16 & 16.1 & 14.8 & 13.3 & 11.1 & 9.4 & 7.3 & 5.6 \\
\hline
\end{tabular}


Table 18.

Site 3, Normalized Deflection Basins

\begin{tabular}{|c|c|c|c|c|c|c|c|}
\hline \multirow{2}{*}{$\begin{array}{l}\text { Test } \\
\text { Number } \\
\text { (* Mean) }\end{array}$} & \multicolumn{7}{|c|}{$\begin{array}{l}\text { Distance from Load, (in) } \\
\text { (Deflection, mils) }\end{array}$} \\
\hline & 0 & 12 & 24 & 36 & 48 & 60 & 72 \\
\hline 1 & 20.5 & 18.7 & 16.0 & 12.7 & 9.6 & 6.7 & 4.0 \\
\hline 2 & 24.1 & 22.1 & 18.3 & 14.3 & 10.6 & 7.2 & 4.4 \\
\hline 3 & 16.8 & 15.5 & 13.3 & 10.6 & 8.0 & 5.4 & 3.4 \\
\hline 4 & 16.2 & 14.6 & 12.3 & 9.7 & 7.6 & 5.7 & 4.3 \\
\hline 5 & 11.0 & 10.2 & 8.9 & 7.4 & 6.1 & 4.7 & 3.7 \\
\hline 6 & 12.6 & 11.4 & 10.0 & 8.0 & 6.2 & 4.5 & 3.1 \\
\hline $7 *$ & 18.5 & 16.7 & 14.2 & 11.1 & 8.4 & 5.7 & 3.6 \\
\hline 8 & 22.4 & 20.5 & 17.5 & 13.7 & 10.5 & 7.2 & 4.6 \\
\hline 9 & 28.5 & 25.2 & 21.1 & 17.6 & 12.4 & 8.3 & 4.1 \\
\hline 10 & 20.8 & 19.2 & 16.6 & 13.3 & 10.1 & 7.0 & 4.5 \\
\hline 11 & 21.0 & 19.3 & 16.3 & 12.6 & 9.3 & 6.1 & 3.8 \\
\hline 12 & 23.5 & 20.6 & 16.5 & 12.3 & 8.6 & 5.4 & 3.2 \\
\hline 13 & 19.7 & 17.7 & 16.8 & 11.1 & 7.8 & 4.6 & 2.5 \\
\hline 14 & 20.7 & 18.8 & 16.0 & 12.5 & 9.5 & 6.4 & 4.2 \\
\hline 15 & 18.3 & 16.3 & 13.4 & 10.4 & 7.6 & 5.3 & 3.6 \\
\hline 16 & 14.3 & 13.1 & 11.4 & 9.2 & 7.3 & 5.2 & 3.5 \\
\hline
\end{tabular}


Table 19.

Site 4, Normalized Deflection Basins

\begin{tabular}{|c|c|c|c|c|c|c|c|}
\hline \multirow{2}{*}{$\begin{array}{c}\text { Test } \\
\text { Number } \\
\text { (* Mean) }\end{array}$} & \multicolumn{7}{|c|}{$\begin{array}{l}\text { Distance from Load, (in) } \\
\text { (Deflection, mils) }\end{array}$} \\
\hline & 0 & 12 & 24 & 36 & 48 & 60 & 72 \\
\hline 1 & 3.1 & 2.9 & 2.6 & 2.5 & 2.4 & 2.1 & 2.0 \\
\hline 2 & 3.1 & 2.8 & 2.8 & 2.5 & 2.4 & 2.1 & 2.1 \\
\hline 3 & 3.1 & 2.8 & 2.6 & 2.4 & 2.4 & 2.1 & 2.1 \\
\hline 4 & 3.1 & 2.6 & 2.6 & 2.3 & 2.3 & 2.0 & 2.2 \\
\hline 5 & 3.1 & 2.6 & 2.6 & 2.3 & 2.3 & 2.0 & 2.0 \\
\hline 6 & 2.9 & 2.7 & 2.6 & 2.4 & 2.3 & 2.1 & 1.9 \\
\hline $7 *$ & 3.1 & 2.8 & 2.7 & 2.5 & 2.5 & 2.1 & 2.1 \\
\hline 8 & 3.1 & 2.6 & 2.6 & 2.3 & 2.3 & 2.1 & 2.0 \\
\hline 9 & 3.6 & 3.3 & 3.2 & 3.0 & 2.9 & 2.5 & 2.4 \\
\hline 10 & 3.7 & 3.5 & 3.4 & 3.1 & 2.9 & 2.7 & 2.5 \\
\hline 11 & 4.1 & 3.7 & 3.6 & 3.4 & 3.3 & 2.9 & 2.8 \\
\hline 12 & 3.9 & 3.5 & 3.4 & 3.0 & 2.9 & 2.5 & 2.5 \\
\hline 13 & 3.7 & 3.5 & 3.2 & 3.0 & 2.9 & 2.4 & 2.4 \\
\hline 14 & 2.9 & 2.6 & 2.5 & 2.3 & 2.2 & 1.9 & 1.9 \\
\hline 15 & 2.9 & 2.6 & 2.5 & 2.4 & 2.2 & 2.0 & 2.1 \\
\hline 16 & 3.7 & 3.3 & 3.2 & 2.9 & 2.8 & 2.4 & 2.4 \\
\hline
\end{tabular}


Table 20.

Site 5, Normalized Deflection Basins

\begin{tabular}{|c|c|c|c|c|c|c|c|}
\hline \multirow{2}{*}{$\begin{array}{c}\text { Test } \\
\text { Number } \\
\text { (* Mean) }\end{array}$} & \multicolumn{7}{|c|}{$\begin{array}{l}\text { Distance from Load, (in) } \\
\text { (Deflection, mils) }\end{array}$} \\
\hline & 0 & 12 & 24 & 36 & 48 & 60 & 72 \\
\hline 1 & 44.5 & 19.6 & 8.9 & 5.3 & 3.9 & 2.8 & 2.6 \\
\hline 2 & 49.6 & 24.2 & 11.6 & 7.0 & 5.2 & 3.8 & 3.3 \\
\hline 3 & 49.6 & 25.1 & 12.1 & 7.1 & 5.2 & 3.6 & 3.2 \\
\hline 4 & 44.6 & 22.9 & 10.8 & 6.5 & 4.7 & 3.4 & 2.9 \\
\hline 5 & 50.9 & 24.5 & 11.4 & 6.9 & 5.0 & 3.6 & 3.1 \\
\hline 6 & 48.6 & 23.7 & 10.6 & 6.3 & 4.6 & 3.3 & 2.9 \\
\hline 7 & 48.9 & 23.4 & 10.7 & 6.4 & 4.7 & 3.2 & 2.8 \\
\hline 8 & 50.6 & 24.9 & 11.5 & 6.8 & 4.9 & 3.5 & 2.9 \\
\hline 9 & 50.5 & 26.5 & 12.8 & 7.7 & 5.5 & 4.0 & 3.1 \\
\hline 10 & 56.6 & 29.4 & 13.6 & 7.6 & 5.3 & 3.9 & 3.3 \\
\hline 11 & 54.4 & 27.7 & 13.5 & 8.1 & 5.7 & 4.1 & 3.4 \\
\hline 12 & 52.8 & 25.8 & 12.6 & 7.8 & 5.5 & 4.1 & 3.5 \\
\hline $13 *$ & 50.8 & 25.0 & 11.7 & 7.0 & 5.1 & 3.6 & 3.2 \\
\hline 14 & 52.0 & 24.3 & 11.5 & 7.0 & 5.1 & 3.7 & 3.2 \\
\hline 15 & 51.0 & 24.7 & 12.1 & 7.5 & 5.5 & 4.1 & 3.6 \\
\hline 16 & 51,3 & 24.2 & 11.7 & 7.0 & 5.1 & 3.6 & 3.1 \\
\hline
\end{tabular}


Table 21.

Site 6, Normalized Deflection Basins

\begin{tabular}{|c|c|c|c|c|c|c|c|}
\hline \multirow{2}{*}{$\begin{array}{l}\text { Test } \\
\text { Number } \\
\text { (* Mean) }\end{array}$} & \multicolumn{7}{|c|}{$\begin{array}{l}\text { Distance from Load, (in) } \\
\text { (Deflection, mils) }\end{array}$} \\
\hline & 0 & 12 & 24 & 36 & 48 & 60 & 72 \\
\hline 1 & 73.9 & 44.1 & 20.8 & 10.8 & 7.1 & 5.4 & 5.1 \\
\hline 2 & 63.4 & 39.6 & 20.3 & 10.9 & 6.9 & 5.3 & 4.8 \\
\hline 3 & 37.0 & 24.3 & 14.5 & 9.1 & 6.4 & 4.8 & 4.3 \\
\hline 4 & 38.5 & 25.9 & 15.9 & 10.1 & 6.5 & 4.6 & 4.3 \\
\hline 5 & 38.9 & 23.9 & 13.4 & 8.0 & 5.6 & 3.8 & 3.7 \\
\hline 6 & 25.4 & 12.7 & 7.6 & 5.5 & 4.6 & 3.9 & 3.7 \\
\hline 7 & 31.1 & 19.9 & 11.1 & 6.7 & 5.0 & 3.9 & 3.7 \\
\hline 8 & 43.8 & 22.9 & 11.4 & 6.7 & 4.7 & 3.5 & 3.4 \\
\hline 9 & 76.9 & 40.0 & 15.7 & 7.1 & 4.8 & 3.9 & 3.6 \\
\hline 10 & 58.1 & 32.7 & 14.8 & 7.7 & 5.4 & 4.5 & 4.1 \\
\hline 11 & 75.7 & 43.2 & 19.6 & 10.1 & 6.6 & 5.0 & 4.7 \\
\hline 12 & 40.3 & 24.5 & 14.1 & 8.6 & 5.9 & 4.3 & 3.9 \\
\hline $13 *$ & 47.7 & 25.6 & 13.9 & 8.1 & 5.4 & 4.0 & 3.7 \\
\hline 14 & 39.4 & 22.7 & 12.6 & 7.6 & 5.4 & 4.2 & 3.6 \\
\hline 15 & 40.3 & 23.7 & 13.6 & 8.5 & 5.8 & 4.5 & 3.7 \\
\hline 16 & 36.3 & 21.0 & 11.8 & 7.5 & 5.5 & 3.7 & 3.7 \\
\hline
\end{tabular}


Table 22.

Site 7, Normalized Deflection Basins

\begin{tabular}{|c|c|c|c|c|c|c|c|}
\hline \multirow{2}{*}{$\begin{array}{c}\text { Test } \\
\text { Number } \\
\text { (* Mean) }\end{array}$} & \multicolumn{7}{|c|}{$\begin{array}{l}\text { Distance from Load, (in) } \\
\text { (Deflection, mils) }\end{array}$} \\
\hline & 0 & 12 & 24 & 36 & 48 & 60 & 72 \\
\hline 1 & 44.8 & 12.1 & 1.7 & 1.4 & 1.6 & 1.2 & 1.2 \\
\hline 2 & 72.7 & 24.7 & 2.7 & 1.0 & 1.7 & 1.5 & 1.4 \\
\hline 3 & 86.5 & 28.6 & 4.1 & 2.4 & 2.3 & 1.7 & 1.7 \\
\hline 4 & 74.5 & 24.5 & 4.0 & 1.3 & 1.3 & 0.9 & 1.1 \\
\hline 5 & 59.0 & 14.4 & 0.0 & 0.8 & 1.5 & 1.2 & 1.2 \\
\hline 6 & 63.7 & 20.4 & 3.4 & 2.3 & 2.2 & 1.7 & 1.6 \\
\hline 7 & 44.1 & 12.0 & 0.8 & 0.9 & 1.3 & 1.1 & 1.1 \\
\hline 8 & 51.2 & 17.8 & 2.9 & 1.2 & 1.7 & 1.5 & 1.5 \\
\hline 9 & 64.0 & 16.8 & 2.3 & 2.4 & 2.2 & 1.7 & 1.7 \\
\hline 10 & 46.3 & 10.7 & 2.2 & 2.2 & 1.7 & 1.4 & 1.2 \\
\hline $11 *$ & 67.4 & 19.7 & 2.5 & 1.5 & 1.7 & 1.4 & 1.4 \\
\hline 12 & 51.7 & 11.9 & 1.5 & 1.9 & 1.7 & 1.5 & 1.4 \\
\hline 13 & 47.4 & 12.8 & 1.7 & 1.5 & 1.5 & 1.1 & 1.2 \\
\hline 14 & 57.0 & 14.1 & 1.5 & 1.8 & 1.7 & 1.2 & 1.2 \\
\hline 15 & 65.8 & 16.7 & 0.9 & 1.0 & 1.3 & 0.9 & 1.1 \\
\hline 16 & 55.5 & 13.9 & 0.8 & 1.0 & 1.2 & 1.0 & 1.0 \\
\hline
\end{tabular}


Table 23.

Site 8, Normalized Deflection Basins

\begin{tabular}{|c|c|c|c|c|c|c|c|}
\hline \multirow{2}{*}{$\begin{array}{c}\text { Test } \\
\text { Number } \\
\text { (* Mean) }\end{array}$} & \multicolumn{7}{|c|}{$\begin{array}{c}\text { Distance from Load, (in) } \\
\text { (Deflection, mils) }\end{array}$} \\
\hline & 0 & 12 & 24 & 36 & 48 & 60 & 72 \\
\hline 1 & 29.5 & 13.4 & 5.2 & 2.1 & 1.2 & 1.0 & 1.0 \\
\hline 2 & 25.8 & 12.4 & 5.3 & 2.1 & 1.5 & 0.9 & 1.1 \\
\hline 3 & 28.5 & 13.5 & 5.3 & 1.7 & 1.2 & 1.0 & 1.0 \\
\hline 4 & 27.9 & 12.2 & 5.8 & 2.7 & 1.6 & 0.9 & 1.1 \\
\hline 5 & 23.7 & 12.2 & 5.9 & 2.6 & 1.5 & 0.9 & 1.0 \\
\hline 6 & 22.9 & 12.4 & 6.5 & 3.0 & 1.7 & 1.0 & 1.1 \\
\hline 7 & 21.2 & 12.1 & 6.5 & 3.1 & 1.8 & 1.0 & 1.1 \\
\hline $8 *$ & 26.8 & 13.2 & 5.9 & 2.5 & 1.4 & 0.8 & 1.1 \\
\hline 9 & 34.3 & 15.1 & 6.6 & 2.8 & 1.4 & 0.9 & 0.9 \\
\hline 10 & 30.2 & 15.1 & 7.3 & 3.5 & 1.8 & 1.0 & 1.0 \\
\hline 11 & 32.5 & 14.3 & 6.2 & 2.5 & 1.4 & 0.8 & 1.7 \\
\hline 12 & 33.6 & 15.4 & 6.6 & 2.7 & 1.4 & 0.8 & 1.0 \\
\hline 13 & 33.7 & 15.2 & 5.8 & 2.1 & 1.2 & 0.7 & 1.1 \\
\hline 14 & 36.1 & 15.5 & 5.8 & 2.1 & 1.2 & 0.8 & 1.1 \\
\hline 15 & 29.0 & 14.5 & 6.0 & 2.3 & 1.2 & 0.9 & 1.0 \\
\hline 16 & 36.5 & 13.9 & 5.2 & 2.1 & 1.5 & 1.0 & 1.2 \\
\hline
\end{tabular}


Table 24.

Site 9, Normalized Deflection Basins

\begin{tabular}{|c|c|c|c|c|c|c|c|}
\hline \multirow{2}{*}{$\begin{array}{c}\text { Test } \\
\text { Number } \\
\text { (* Mean) }\end{array}$} & \multicolumn{7}{|c|}{$\begin{array}{l}\text { Distance form Load, (in) } \\
\text { (Deflection, mils) }\end{array}$} \\
\hline & 0 & 12 & 24 & 36 & 48 & 60 & 72 \\
\hline 1 & 13.1 & 8.1 & 7.7 & 6.6 & 6.0 & 5.1 & 4.3 \\
\hline 2 & 13.6 & 8.2 & 7.8 & 6.8 & 6.0 & 4.9 & 4.4 \\
\hline 3 & 12.5 & 7.7 & 7.3 & 6.2 & 5.4 & 4.8 & 4.1 \\
\hline 4 & 10.8 & 7.4 & 7.0 & 5.8 & 5.2 & 4.2 & 3.6 \\
\hline 5 & 14.1 & 8.5 & 8.0 & 6.9 & 6.2 & 4.9 & 4.2 \\
\hline $6 *$ & 13.2 & 8.1 & 7.7 & 6.5 & 5.7 & 4.7 & 4.2 \\
\hline 7 & 14.3 & 9.2 & 8.5 & 7.3 & 6.3 & 5.1 & 4.2 \\
\hline 8 & 11.7 & 8.2 & 7.6 & 6.5 & 5.8 & 4.6 & 4.0 \\
\hline 9 & 12.3 & 8.2 & 7.8 & 6.6 & 5.8 & 4.7 & 4.1 \\
\hline 10 & 14.1 & 8.3 & 7.9 & 6.5 & 5.9 & 4.9 & 4.3 \\
\hline 11 & 13.4 & 7.1 & 6.8 & 6.1 & 5.3 & 4.6 & 4.1 \\
\hline 12 & 12.0 & 7.7 & 7.2 & 6.1 & 5.4 & 4.5 & 3.9 \\
\hline 13 & 11.6 & 7.9 & 7.6 & 6.4 & 5.8 & 4.7 & 4.1 \\
\hline 14 & 11.7 & 7.1 & 6.9 & 5.7 & 5.4 & 4.5 & 3.7 \\
\hline 15 & 16.2 & 9.9 & 9.3 & 8.0 & 6.6 & 5.8 & 4.7 \\
\hline 16 & 17.6 & 8.5 & 7.9 & 6.7 & 5.8 & 4.8 & 4.2 \\
\hline
\end{tabular}


Table 25.

Site 10, Normalized Deflection Basins

\begin{tabular}{|c|c|c|c|c|c|c|c|}
\hline \multirow{2}{*}{$\begin{array}{c}\text { Test } \\
\text { Number } \\
\text { (* Mean) }\end{array}$} & \multicolumn{7}{|c|}{$\begin{array}{l}\text { Distance from Load, (in) } \\
\text { (Deflection, mils) }\end{array}$} \\
\hline & 0 & 12 & 24 & 36 & 48 & 60 & 72 \\
\hline 1 & 20.9 & 10.7 & 9.0 & 7.0 & 5.3 & 3.7 & 2.5 \\
\hline 2 & 20.8 & 13.0 & 10.3 & 7.4 & 5.1 & 3.2 & 2.2 \\
\hline 3 & 19.3 & 13.0 & 10.5 & 7.3 & 5.5 & 4.0 & 2.8 \\
\hline 4 & 16.6 & 11.2 & 9.5 & 7.4 & 5.3 & 3.1 & 2.2 \\
\hline 5 & 17.5 & 10.0 & 8.0 & 6.1 & 4.5 & 3.2 & 2.3 \\
\hline 6 & 17.0 & 10.1 & 8.6 & 6.9 & 5.3 & 3.7 & 28 \\
\hline 7 & 16.2 & 9.3 & 7.7 & 6.0 & 4.7 & 3.4 & 2.5 \\
\hline 8 & 17.6 & 11.3 & 9.6 & 7.4 & 5.6 & 4.1 & 3.0 \\
\hline 9 & 15.3 & 10.6 & 8.5 & 6.4 & 4.9 & 3.5 & 2.7 \\
\hline 10 & 23.3 & 16.7 & 13.7 & 10.3 & 7.5 & 5.2 & 3.7 \\
\hline 11 & 15.8 & 11.4 & 9.7 & 7.6 & 5.7 & 4.2 & 2.9 \\
\hline 12 & 14.4 & 9.0 & 7.5 & 5.6 & 4.2 & 2.9 & 2.1 \\
\hline 13 & 21.4 & 15.3 & 12.7 & 9.6 & 7.0 & 4.7 & 3.1 \\
\hline 14 & 17.9 & 11.3 & 8.6 & 6.0 & 4.2 & 2.7 & 1.8 \\
\hline $15 *$ & 18.8 & 12.7 & 10.2 & 7.8 & 5.7 & 3.9 & 2.6 \\
\hline 16 & 20.7 & 13.6 & 9.5 & 6.5 & 4.6 & 2.9 & 1.9 \\
\hline
\end{tabular}


Table 26.

Site 11, Normalized Deflection Basins

\begin{tabular}{|c|c|c|c|c|c|c|c|}
\hline \multirow{2}{*}{$\begin{array}{l}\text { Test } \\
\text { Number } \\
\text { (* Mean) }\end{array}$} & \multicolumn{7}{|c|}{$\begin{array}{l}\text { Distance from Load, (in) } \\
\text { (Deflection, mils) }\end{array}$} \\
\hline & 0 & 12 & 24 & 36 & 48 & 60 & 72 \\
\hline 1 & 30.2 & 24.3 & 17.6 & 12.6 & 9.3 & 6.4 & 4.4 \\
\hline 2 & 21.9 & 18.6 & 15.6 & 12.2 & 8.6 & 5.1 & 3.5 \\
\hline 3 & 15.9 & 13.0 & 10.1 & 7.2 & 4.9 & 3.0 & 2.1 \\
\hline 4 & 26.4 & 23.0 & 17.5 & 13.0 & 9.2 & 5.8 & 3.7 \\
\hline 5 & 12.1 & 10.8 & 9.4 & 7.6 & 5.7 & 3.9 & 2.8 \\
\hline 6 & 12.1 & 10.0 & 8.6 & 6.8 & 5.2 & 4.0 & 3.2 \\
\hline 7 & 10.2 & 8.6 & 7.4 & 6.0 & 4.7 & 3.5 & 2.6 \\
\hline 8 & 21.5 & 15.1 & 11,8 & 8.7 & 6.3 & 4.7 & 3.5 \\
\hline 9 & 14.4 & 11.7 & 9.0 & 6.5 & 4.7 & 3.1 & 2.2 \\
\hline 10 & 18.0 & 14.8 & 11.9 & 9.0 & 6.7 & 4.9 & 3.6 \\
\hline 11 & 14.0 & 11.1 & 8.5 & 6.0 & 4.1 & 2.8 & 2.1 \\
\hline 12 & 22.5 & 17.6 & 14.5 & 10.5 & 7.9 & 5.5 & 4.5 \\
\hline 13 & 12.4 & 10.0 & 7.9 & 5.8 & 4.2 & 2.8 & 1.9 \\
\hline 14 & 13.8 & 11.7 & 9.3 & 6.9 & 5.0 & 3.6 & 2.5 \\
\hline 15 & 13.3 & 11.6 & 9.8 & 7.6 & 5.8 & 4.1 & 3.0 \\
\hline $16 *$ & 17.0 & 14.1 & 11.0 & 8.1 & 6.0 & 4.1 & 3.0 \\
\hline
\end{tabular}


Table 27.

Site 12, Normalized Deflection Basins

\begin{tabular}{|c|c|c|c|c|c|c|c|}
\hline \multirow{2}{*}{$\begin{array}{c}\text { Test } \\
\text { Number } \\
\text { (* Mean) }\end{array}$} & \multicolumn{7}{|c|}{$\begin{array}{l}\text { Distance from Load, (in) } \\
\text { (Deflection, mils) }\end{array}$} \\
\hline & 0 & 12 & 24 & 36 & 48 & 60 & 72 \\
\hline 1 & 24.4 & 8.5 & 7.8 & 6.1 & 5.5 & 4.5 & 4.0 \\
\hline 2 & 23.1 & 8.9 & 7.9 & 6.5 & 5.4 & 4.5 & 4.0 \\
\hline 3 & 22.1 & 8.6 & 7.7 & 6.1 & 4.9 & 3.8 & 3.3 \\
\hline $4 *$ & 22.8 & 8.4 & 7.3 & 5.6 & 4.6 & 3.4 & 2.9 \\
\hline 5 & 22.6 & 7.8 & 6.9 & 5.4 & 4.5 & 3.3 & 2.9 \\
\hline 6 & 20.9 & 7.6 & 6.5 & 5.0 & 4.0 & 3.0 & 2.5 \\
\hline 7 & 19.4 & 6.8 & 5.7 & 4.4 & 3.4 & 2.5 & 2.0 \\
\hline 8 & 21.8 & 7.8 & 6.9 & 5.5 & 4.4 & 3.3 & 2.7 \\
\hline 9 & 20.9 & 9.4 & 7.8 & 6.0 & 4.6 & 3.3 & 2.5 \\
\hline 10 & 21.6 & 7.6 & 6.3 & 4.7 & 3.6 & 2.5 & 2.1 \\
\hline 11 & 21.3 & 8.4 & 6.8 & 5.0 & 3.8 & 2.7 & 2.2 \\
\hline 12 & 20.7 & 8.0 & 6.1 & 4.2 & 3.1 & 2.2 & 1.8 \\
\hline 13 & 22.0 & 8.9 & 7.6 & 5.6 & 4.1 & 2.9 & 2.4 \\
\hline 14 & 21.1 & 9.5 & 7.8 & 5.9 & 4.9 & 3.7 & 3.2 \\
\hline 15 & 22.3 & 9.3 & 7.6 & 5.9 & 4.9 & 3.8 & 3.4 \\
\hline 16 & 21.3 & 9.7 & 8.4 & 6.5 & 5.2 & 3.9 & 3.3 \\
\hline
\end{tabular}


Table 28.

ISM (Kips/inch) vs Test Number, Sites $1-4$

\begin{tabular}{|c|c|c|c|c|}
\hline Test Number & $\begin{array}{c}\text { Site } 1 \\
\text { ISM }\end{array}$ & $\begin{array}{c}\text { Site } 2 \\
\text { ISM }\end{array}$ & $\begin{array}{c}\text { Site } \\
\text { ISM }\end{array}$ & $\begin{array}{c}\text { Site } 4 \\
\text { ISM }\end{array}$ \\
\hline 1 & 6,199 & 1,649 & 1,244 & 8,312 \\
\hline 2 & 5,955 & 1,086 & 1,057 & 8,364 \\
\hline 3 & 6,136 & 1,559 & 1,523 & 8,287 \\
\hline 4 & 6,300 & 1,660 & 1,578 & 8,432 \\
\hline 5 & 6,444 & 1,747 & 2,327 & 8,448 \\
\hline 6 & 6,586 & 1,473 & 2,032 & 8,829 \\
\hline 7 & 6,359 & 1,878 & 1,383 & 8,256 \\
\hline 8 & 6,217 & 1,831 & 1,140 & 8,358 \\
\hline 9 & 6,243 & 1,529 & 869 & 7,093 \\
\hline 10 & 6,231 & 1,783 & 1,229 & 6,927 \\
\hline 11 & 6,004 & 1,617 & 1,217 & 6,355 \\
\hline 12 & 6,082 & 1,515 & 1,086 & 6,660 \\
\hline 13 & 6,312 & 1,527 & 1,293 & 7,003 \\
\hline 14 & 6,190 & 1,598 & 1,236 & 8,829 \\
\hline 15 & 5,944 & 1,648 & 1,397 & 8,875 \\
\hline 16 & 6,072 & 1,572 & 1,790 & 6,991 \\
\hline Mean & 6,205 & 1,605 & 1,402 & 7,877 \\
\hline Standard Dev & 175 & 182 & 376 & 867 \\
\hline $\mathrm{CoV}$ & 2.8 & 11.3 & 26.8 & 11.0 \\
\hline 958 & 316 & 329 & 378 & 1,567 \\
\hline Mean - 958 & 5,889 & 1,276 & 1,024 & 6,310 \\
\hline
\end{tabular}


Table 29.

ISM (Kips/inch) vs Test Number, Sites $5-8$

\begin{tabular}{|c|c|c|c|c|}
\hline Test Number & $\begin{array}{c}\text { Site } \\
\text { ISM }\end{array}$ & $\begin{array}{l}\text { Site } 6 \\
\text { ISM }\end{array}$ & $\begin{array}{c}\text { Site } 7 \\
\text { ISM }\end{array}$ & $\begin{array}{c}\text { Site } 8 \\
\text { ISM }\end{array}$ \\
\hline 1 & 548 & 344 & 551 & 850 \\
\hline 2 & 491 & 401 & 339 & 973 \\
\hline 3 & 488 & 686 & 285 & 880 \\
\hline 4 & 547 & 660 & 331 & 900 \\
\hline 5 & 479 & 653 & 418 & 1,059 \\
\hline 6 & 501 & 1,000 & 387 & 1,098 \\
\hline 7 & 498 & 817 & 560 & 1,184 \\
\hline 8 & 481 & 580 & 482 & 936 \\
\hline 9 & 483 & 330 & 385 & 732 \\
\hline 10 & 431 & 437 & 533 & 829 \\
\hline 11 & 448 & 335 & 366 & 772 \\
\hline 12 & 462 & 631 & 477 & 747 \\
\hline 13 & 480 & 533 & 520 & 744 \\
\hline 14 & 468 & 645 & 433 & 694 \\
\hline 15 & 478 & 631 & 375 & 866 \\
\hline 16 & 476 & 700 & 444 & 687 \\
\hline Mean & 486 & 587 & 431 & 872 \\
\hline Standard Dev & 30 & 185 & 84 & 148 \\
\hline $\mathrm{CoV}$ & 6.2 & 31.5 & 19.5 & 17.0 \\
\hline 958 & 54 & 334 & 152 & 267 \\
\hline Mean - 958 & 432 & 253 & 279 & 605 \\
\hline
\end{tabular}


Table 30 .

ISM (Kips/inch) vs Test Number, Sites $9-12$

\begin{tabular}{|c|c|c|c|c|}
\hline Test Number & $\begin{array}{c}\text { Site } 9 \\
\text { ISM }\end{array}$ & $\begin{array}{c}\text { Site } 10 \\
\text { ISM }\end{array}$ & $\begin{array}{l}\text { Site } 11 \\
\text { ISM }\end{array}$ & $\begin{array}{l}\text { Site } 12 \\
\text { ISM }\end{array}$ \\
\hline 1 & 1,937 & 1,222 & 835 & 1,035 \\
\hline 2 & 1,858 & 1,226 & 1,151 & 1,094 \\
\hline 3 & 2,029 & 1,323 & 1,590 & 1,144 \\
\hline 4 & 2,339 & 1,543 & 956 & 1,107 \\
\hline 5 & 1,799 & 1,464 & 2,093 & 1,120 \\
\hline 6 & 1,918 & 1,504 & 2,085 & 1,211 \\
\hline 7 & 1,768 & 1,581 & 2,462 & 1,306 \\
\hline 8 & 2,162 & 1,450 & 1,171 & 1,158 \\
\hline 9 & 2,064 & 1,668 & 1,749 & 1,210 \\
\hline 10 & 1.789 & 1,097 & 1,400 & 1,170 \\
\hline 11 & 1,881 & 1,612 & 1,796 & 1,187 \\
\hline 12 & 2,109 & 1,777 & 1,122 & 1,220 \\
\hline 13 & 2,186 & 1,192 & 2,041 & 1,149 \\
\hline 14 & 2,168 & 1,424 & 1,833 & 1,198 \\
\hline 15 & 1,560 & 1,359 & 1,893 & 1,132 \\
\hline 16 & 1,438 & 1,232 & 1,480 & 1.189 \\
\hline Mean & 1,938 & 1,418 & 1,604 & 1,165 \\
\hline Std Dev & 238 & 193 & 468 & 62 \\
\hline $\mathrm{CoV}$ & 12.3 & 13.6 & 29.2 & 5.4 \\
\hline 958 & 430 & 349 & 846 & 112 \\
\hline Mean - 958 & 1,508 & 1,609 & 758 & 1,053 \\
\hline
\end{tabular}


Table 31.

Site 1, Layer Moduli (psi) vs Test Number

\begin{tabular}{|c|c|c|c|c|}
\hline $\begin{array}{c}\text { Test } \\
\text { Number }\end{array}$ & AC Modulus & PCC Modulus & $\begin{array}{c}\text { Base } \\
\text { Modulus }\end{array}$ & $\begin{array}{l}\text { Subgrade } \\
\text { Modulus }\end{array}$ \\
\hline 1 & $\longrightarrow$ & $7,000,000$ & $\longrightarrow$ & 22,052 \\
\hline 2 & $\longrightarrow$ & $7,000,000$ & - & 19,440 \\
\hline 3 & $\longrightarrow$ & $7,000,000$ & - & 18,512 \\
\hline 4 & $\longrightarrow$ & $7,000,000$ & $\longrightarrow$ & 21,043 \\
\hline 5 & - & $7,000,000$ & $\longrightarrow$ & 21,173 \\
\hline 6 & - & $7,000,000$ & - & 20,450 \\
\hline 7 & - & $7,000,000$ & - & 21,128 \\
\hline 8 & - & $7,000,000$ & - & 21,694 \\
\hline 9 & - & $7,000,000$ & - & 20,401 \\
\hline 10 & $\longrightarrow$ & $7,000,000$ & - & 21,478 \\
\hline 11 & $\longrightarrow$ & $7,000,000$ & - & 20,306 \\
\hline 12 & - & $7,000,000$ & - & 19,732 \\
\hline 13 & $\longrightarrow$ & $7,000,000$ & $\longrightarrow$ & 20,695 \\
\hline 14 & - & $7,000,000$ & - & 19,945 \\
\hline 15 & - & $7,000,000$ & - & 18,951 \\
\hline 16 & - & $7,000,000$ & - & 20,172 \\
\hline Mean & -- & $-\ldots$ & - & 20,448 \\
\hline Std Dev & - & $-+-1-$ & - & 982 \\
\hline $\mathrm{CoV}$ & - & - & - & 5 \\
\hline 958 & - & - & - & 1,774 \\
\hline $\begin{array}{c}\text { Mean - } \\
958\end{array}$ & - & - & - & 18,674 \\
\hline
\end{tabular}


Table 32 .

Site 2, Layer Moduli (psi) vs Test Number

\begin{tabular}{|c|c|c|c|c|}
\hline $\begin{array}{c}\text { Test } \\
\text { Number }\end{array}$ & AC Modulus & PCC Modulus & $\begin{array}{l}\text { Base } \\
\text { Modulus }\end{array}$ & $\begin{array}{l}\text { Subgrade } \\
\text { Modulus }\end{array}$ \\
\hline 1 & $\longrightarrow$ & $4,171,417$ & - & 11,039 \\
\hline 2 & - & $2,754,897$ & - & 6,989 \\
\hline 3 & - & $3,422,143$ & - & 11,242 \\
\hline 4 & $\longrightarrow$ & $3,857,066$ & - & 12,172 \\
\hline 5 & $\longrightarrow$ & $4,376,238$ & - & 12,261 \\
\hline 6 & - & $3,920,763$ & $\longrightarrow$ & 9,607 \\
\hline 7 & - & $3,541,076$ & - & 15,521 \\
\hline 8 & - & $3,979,508$ & - & 13,993 \\
\hline 9 & - & $3,390,442$ & - & 11,366 \\
\hline 10 & - & $3,549,686$ & - & 14,035 \\
\hline 11 & - & $3,632,412$ & - & 11,799 \\
\hline 12 & - & $3,974,916$ & + & 9.579 \\
\hline 13 & $\longrightarrow$ & $3,528,166$ & $\longrightarrow$ & 10,930 \\
\hline 14 & $\longrightarrow$ & $3,918,623$ & - & 11,113 \\
\hline 15 & - & $4,142,416$ & - & 11,246 \\
\hline 16 & - & $3,447,769$ & - & 11,957 \\
\hline Mean & - & $3,725,471$ & - & 11,554 \\
\hline Std Dev & - & 395,947 & - & 1,976 \\
\hline $\mathrm{CoV}$ & - & 11 & - & 17 \\
\hline 958 & - & 715,457 & - & 3,571 \\
\hline $\begin{array}{c}\text { Mean - } \\
958\end{array}$ & - & $3,010,014$ & $\longrightarrow$ & 7,983 \\
\hline
\end{tabular}


Table 33.

Site 3, Layer Moduli (psi) vs Test Number

\begin{tabular}{|c|c|c|c|c|}
\hline $\begin{array}{c}\text { Test } \\
\text { Number }\end{array}$ & AC Modulus & PCC Modulus & $\begin{array}{c}\text { Base } \\
\text { Modulus }\end{array}$ & $\begin{array}{l}\text { Subgrade } \\
\text { Modulus }\end{array}$ \\
\hline 1 & - & $3,472,405$ & - & 14,168 \\
\hline 2 & $\longrightarrow$ & $2,648,426$ & $\longrightarrow$ & 12,821 \\
\hline 3 & - & $4,288,907$ & - & 17,082 \\
\hline 4 & $\longrightarrow$ & $6,342,678$ & - & 16,024 \\
\hline 5 & $\longrightarrow$ & $10,000,000$ & - & 19,997 \\
\hline 6 & - & $7,722,817$ & 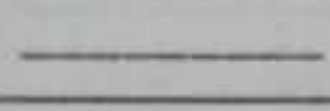 & 20,311 \\
\hline 7 & - & $3,766,783$ & $\longrightarrow$ & 16,117 \\
\hline 8 & - & $3,213,799$ & 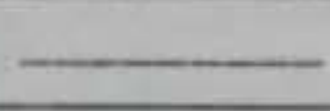 & 12,957 \\
\hline 9 & - & $1,898,888$ & - & 11,587 \\
\hline 10 & - & $3,662,124$ & - & 13,365 \\
\hline 11 & - & $2,946,777$ & - & 14,780 \\
\hline 12 & - & $1,936,795$ & - & 15,963 \\
\hline 13 & - & $2,086,453$ & - & 18,224 \\
\hline 14 & - & $3,497,141$ & - & 14,173 \\
\hline 15 & + & $3,704,261$ & - & 17,196 \\
\hline 16 & $\longrightarrow$ & $6,457,424$ & - & 18,019 \\
\hline Mean & - & $4,227,854$ & - & 15,799 \\
\hline Std Dev & - & $2,270,296$ & - & 2,576 \\
\hline $\mathrm{CoV}$ & - & 54 & - & 16 \\
\hline 958 & - & $4,102,313$ & $\longrightarrow$ & 4,655 \\
\hline $\begin{array}{c}\text { Mean - } \\
958\end{array}$ & - & 125,540 & - & 11,144 \\
\hline
\end{tabular}


Table 34.

Site 4, Layer Moduli (psi) vs Test Number

\begin{tabular}{|c|c|c|c|c|}
\hline $\begin{array}{c}\text { Test } \\
\text { Number }\end{array}$ & AC Modulus & PCC Modulus & $\begin{array}{l}\text { Base } \\
\text { Modulus }\end{array}$ & $\begin{array}{c}\text { Subgrade } \\
\text { Modulus }\end{array}$ \\
\hline 1 & 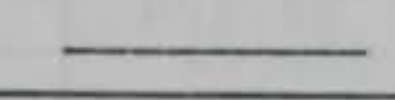 & $7,000,000$ & - & 26,498 \\
\hline 2 & $\longrightarrow$ & $7,000,000$ & + & 25,855 \\
\hline 3 & $\longrightarrow$ & $7,000,000$ & - & 26,454 \\
\hline 4 & - & $7,000,000$ & - & 27,876 \\
\hline 5 & $\longrightarrow$ & $7,000,000$ & - & 28,034 \\
\hline 6 & - & $7,000,000$ & - & 28,602 \\
\hline 7 & $\longrightarrow$ & $7,000,000$ & - & 25,553 \\
\hline 8 & - & $7,000,000$ & - & 27,973 \\
\hline 9 & - & $7,000,000$ & - & 19,682 \\
\hline 10 & - & $7,000,000$ & - & 18,387 \\
\hline 11 & - & $7,000,000$ & - & 15,737 \\
\hline 12 & - & $6,852,343$ & - & 19,127 \\
\hline 13 & - & $7,000,000$ & - & 19,476 \\
\hline 14 & -+- & $7,000,000$ & - & 29,776 \\
\hline 15 & - & $7,000,000$ & - & 28,495 \\
\hline 16 & - & $7,000,000$ & $\ldots$ & 20,209 \\
\hline Mean & - & - & - & 24,233 \\
\hline Std Dev & - & + & - & 4,590 \\
\hline $\mathrm{CoV}$ & - & - & - & 19 \\
\hline 958 & - & - & - & 8,294 \\
\hline $\begin{array}{c}\text { Mean - } \\
958\end{array}$ & 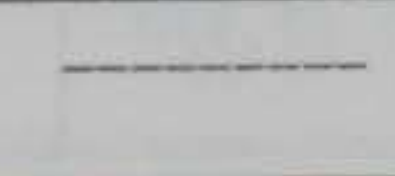 & $\ldots$ & 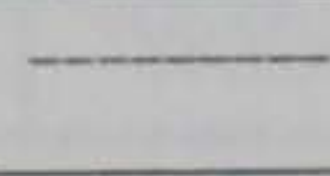 & 15,939 \\
\hline
\end{tabular}


Table 35.

Site 5, Layer Moduli (psi) vs Test Number

\begin{tabular}{|c|c|c|c|c|}
\hline $\begin{array}{c}\text { Test } \\
\text { Number }\end{array}$ & AC Modulus & PCC Modulus & $\begin{array}{l}\text { Base } \\
\text { Modulus }\end{array}$ & $\begin{array}{l}\text { Subgrade } \\
\text { Modulus }\end{array}$ \\
\hline 1 & 99,429 & $\longrightarrow$ & 32,174 & 27,035 \\
\hline 2 & 89,991 & $\longrightarrow$ & 32,016 & 20,351 \\
\hline 3 & 77,337 & $\longrightarrow$ & 31,911 & 20,425 \\
\hline 4 & 85,703 & - & 36,534 & 22,426 \\
\hline 5 & 93,328 & - & 28,959 & 21,136 \\
\hline 6 & 71,807 & - & 32,073 & 23,362 \\
\hline 7 & 96,055 & $\longrightarrow$ & 29,964 & 22,062 \\
\hline 8 & 138,118 & - & 26,207 & 20,478 \\
\hline 9 & 103,567 & - & 29.700 & 18,514 \\
\hline 10 & 90,162 & - & 23,084 & 18,526 \\
\hline 11 & 128,498 & - & 24,274 & 17,399 \\
\hline 12 & 69,348 & - & 32,865 & 18,794 \\
\hline 13 & 190,254 & - & 24,308 & 19,781 \\
\hline 14 & 92,184 & - & 29,629 & 20,434 \\
\hline 15 & 86,880 & - & 35,244 & 18,762 \\
\hline 16 & 88,260 & - & 30,285 & 20,854 \\
\hline Mean & 100,057 & - & 29,952 & 20,646 \\
\hline Std Dev & 30,005 & - & 3,864 & 2,326 \\
\hline $\mathrm{CoV}$ & 30 & - & 13 & 11 \\
\hline 958 & 54,218 & - & 6,982 & 4,202 \\
\hline $\begin{array}{c}\text { Mean - } \\
958\end{array}$ & 45,839 & - & 22,970 & 16,443 \\
\hline
\end{tabular}


Table 36 .

Site 6, Layer Moduli (psi) vs Test Number

\begin{tabular}{|c|c|c|c|c|}
\hline $\begin{array}{c}\text { Test } \\
\text { Number }\end{array}$ & AC Modulus & PCC Modulus & $\begin{array}{l}\text { Base } \\
\text { Modulus }\end{array}$ & $\begin{array}{l}\text { Subgrade } \\
\text { Modulus }\end{array}$ \\
\hline 1 & 93,461 & - & 13,091 & 13,086 \\
\hline 2 & 129,404 & - & 14,384 & 13,655 \\
\hline 3 & 223,566 & - & 34,154 & 15,473 \\
\hline 4 & 267,230 & - & 26,417 & 15,427 \\
\hline 5 & 220,530 & $\longrightarrow$ & 27,817 & 18,260 \\
\hline 6 & 116,786 & - & 163,370 & 21,156 \\
\hline 7 & 296,234 & - & 41,071 & 19,564 \\
\hline 8 & 118,961 & - & 30,527 & 20,968 \\
\hline 9 & 58,589 & - & 13,320 & 19,056 \\
\hline 10 & 75,814 & - & 21,789 & 16,970 \\
\hline 11 & 72,657 & - & 14,106 & 13,898 \\
\hline 12 & 170,631 & $\ldots$ & 30,882 & 16,800 \\
\hline 13 & 154,003 & - & 24,214 & 17,940 \\
\hline 14 & 143,558 & - & 37,001 & 18,294 \\
\hline 15 & 191,019 & - & 30,517 & 17,161 \\
\hline 16 & 160,704 & - & 39,905 & 18,746 \\
\hline Mean & 155,822 & - & 35,160 & 17,278 \\
\hline Std Dev & 69,657 & - & 35,403 & 2,460 \\
\hline $\mathrm{CoV}$ & 45 & - & 101 & 14 \\
\hline 958 & 125,867 & - & 64,020 & 4,445 \\
\hline $\begin{array}{c}\text { Mean - } \\
958\end{array}$ & 29,955 & - & $-28,860$ & 12,833 \\
\hline
\end{tabular}


Table 37.

Site 7, Layer Moduli (psi) vs Test Number

\begin{tabular}{|c|c|c|c|c|}
\hline $\begin{array}{c}\text { Test } \\
\text { Number }\end{array}$ & AC Modulus & PCC Modulus & $\begin{array}{c}\text { Base } \\
\text { Modulus }\end{array}$ & $\begin{array}{l}\text { Subgrade } \\
\text { Modulus }\end{array}$ \\
\hline 1 & 14,649 & $\longrightarrow$ & 73,582 & 74,849 \\
\hline 2 & 10,000 & $\longrightarrow$ & 38,318 & 63,245 \\
\hline 3 & 28,312 & - & 24,150 & 43,751 \\
\hline 4 & 138,964 & - & 20,109 & 90,260 \\
\hline 5 & 34,982 & - & 40,132 & 69,637 \\
\hline 6 & 34,748 & - & 35,107 & 46,997 \\
\hline 7 & 29,335 & -+- & 102,914 & 102,525 \\
\hline 8 & 60,168 & - & 37,572 & 66,519 \\
\hline 9 & 15,863 & - & 61,337 & 51,993 \\
\hline 10 & 22,673 & - & 80,596 & 64,462 \\
\hline 11 & 25,592 & - & 39,049 & 59,511 \\
\hline 12 & 22,889 & - & 78,745 & 66,236 \\
\hline 13 & 27,132 & -- & 68,873 & 71,048 \\
\hline 14 & 26,648 & - & 59,991 & 65,968 \\
\hline 15 & 15,551 & - & 64,678 & 90,274 \\
\hline 16 & 18,656 & - & 105,322 & 92,907 \\
\hline Mean & 32,885 & 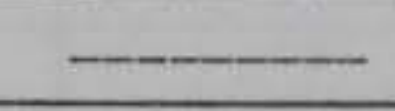 & 58,154 & 70,011 \\
\hline Std Dev & 30,569 & + & 26,085 & 16,733 \\
\hline $\mathrm{CoV}$ & 93 & +- & 45 & 24 \\
\hline 958 & 55,237 & $-\cdots$ & 47,134 & 30,236 \\
\hline $\begin{array}{c}\text { Mean - } \\
958\end{array}$ & $-22,352$ & - & 11,020 & 39,775 \\
\hline
\end{tabular}


Table 38 .

Site 8, Layer Moduli (psi) vs Test Number

\begin{tabular}{|c|c|c|c|c|c|}
\hline $\begin{array}{c}\text { Test } \\
\text { Number }\end{array}$ & AC & Modulus & PCC Modulus & $\begin{array}{l}\text { Base } \\
\text { Modulus }\end{array}$ & $\begin{array}{l}\text { Subgrade } \\
\text { Modulus }\end{array}$ \\
\hline 1 & & 177,353 & $\longrightarrow$ & 15,853 & 67,210 \\
\hline 2 & & 208,911 & $\longrightarrow$ & 19,378 & 63,857 \\
\hline 3 & & 169,986 & $\longrightarrow$ & 15,428 & 71,175 \\
\hline 4 & & 245,290 & $\longrightarrow$ & 16,848 & 59,387 \\
\hline 5 & & 298,940 & - & 16,442 & 62,783 \\
\hline 6 & & 370,198 & -- & 15,669 & 56,844 \\
\hline 7 & & 433,695 & - & 15,754 & 56,683 \\
\hline 8 & & 249,300 & - & 14,288 & 64,270 \\
\hline 9 & & 218,760 & - & 10,165 & 62,388 \\
\hline 10 & & 321,351 & 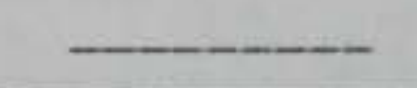 & 8,816 & 54,867 \\
\hline 11 & & 199,570 & -+- & 12,964 & 58,891 \\
\hline 12 & & 216.412 & $\ldots$ & 9.819 & 64,618 \\
\hline 13 & & 157,713 & + & 11,335 & 69,953 \\
\hline 14 & & 149,364 & - & 11,210 & 67,595 \\
\hline 15 & & 215,625 & + & 12,446 & 66,245 \\
\hline 16 & & 116,600 & - & 16,801 & 62,727 \\
\hline Mean & & 234,317 & - & 13,951 & 63,093 \\
\hline Std Dev & & 84,617 & -- & 3,051 & 4,787 \\
\hline $\mathrm{CoV}$ & & 36 & - & 22 & 8 \\
\hline 958 & & 152,899 & - & 5,513 & 8,650 \\
\hline $\begin{array}{c}\text { Mean - } \\
958\end{array}$ & & 81,418 & + & 8,438 & 54,443 \\
\hline
\end{tabular}


Table 39.

Site 9, Layer Moduli (psi) vs Test Number

\begin{tabular}{|c|c|c|c|c|}
\hline $\begin{array}{c}\text { Test } \\
\text { Number }\end{array}$ & AC Modulus & PCC Modulus & $\begin{array}{l}\text { Base } \\
\text { Modulus }\end{array}$ & $\begin{array}{l}\text { Subgrade } \\
\text { Modulus }\end{array}$ \\
\hline 1 & 165,000 & $8,350,874$ & $\longrightarrow$ & 15,787 \\
\hline 2 & 165,000 & $7,665,250$ & - & 16,541 \\
\hline 3 & 165,000 & $8,556,006$ & - & 17,264 \\
\hline 4 & 165,000 & $8,732,465$ & - & 19,306 \\
\hline 5 & 165,000 & $6,771,393$ & - & 16,299 \\
\hline 6 & 165,000 & $7,146,564$ & - & 17,611 \\
\hline 7 & 165,000 & $5,836,538$ & - & 16,323 \\
\hline 8 & 165,000 & $8,514,084$ & - & 17,122 \\
\hline 9 & 165,000 & $8,240,589$ & - & 16,956 \\
\hline 10 & 165,000 & $6,724,429$ & - & 16,794 \\
\hline 11 & 165,000 & $8,987,260$ & - & 16,819 \\
\hline 12 & 165,000 & $8,064,664$ & -+ & 18,626 \\
\hline 13 & 165,000 & $9,497,930$ & - & 15,892 \\
\hline 14 & 165,000 & $9,035,468$ & $+-\cdots$ & 18,821 \\
\hline 15 & 165,000 & $5,735,186$ & $-\cdots$ & 14,327 \\
\hline 16 & 165,000 & $4,544,235$ & - & 18,126 \\
\hline Mean & $+-\cdots$ & $7,650,183$ & - & 17,034 \\
\hline Std Dev & -+ & $1,398,776$ & - & 1,269 \\
\hline $\mathrm{CoV}$ & - & 18 & $-\cdots$ & 7 \\
\hline 958 & $\ldots$ & $2,527,520$ & --+- & 2,293 \\
\hline $\begin{array}{c}\text { Mean - } \\
958\end{array}$ & $---\cdots$ & $5,122,663$ & -- & 14,741 \\
\hline
\end{tabular}


Table 40.

Site 10, Layer Moduli (psi) vs Test Number

\begin{tabular}{|c|c|c|c|c|}
\hline $\begin{array}{c}\text { Test } \\
\text { Number }\end{array}$ & AC Modulus & PCC Modulus & $\begin{array}{c}\text { Base } \\
\text { Modulus }\end{array}$ & $\begin{array}{l}\text { Subgrade } \\
\text { Modulus }\end{array}$ \\
\hline 1 & 117,251 & $3,530,344$ & - & 24,680 \\
\hline 2 & 229,959 & 542,390 & - & 25,243 \\
\hline 3 & 230,694 & $1,455,572$ & - & 22,234 \\
\hline 4 & 329,045 & 944,952 & - & 25,886 \\
\hline 5 & 165,565 & $3,094,393$ & & 28,092 \\
\hline 6 & 178,124 & $4,750,496$ & & 23,784 \\
\hline 7 & 174,768 & $5,000,000$ & - & 26,820 \\
\hline 8 & 210,434 & $3,263,822$ & $\longrightarrow$ & 21,992 \\
\hline 9 & 265,101 & $3,042,415$ & - & 25,134 \\
\hline 10 & 269,371 & 776,676 & - & 16,670 \\
\hline 11 & 332,224 & $2,316,374$ & - & 21,855 \\
\hline 12 & 257.567 & $2,893,071$ & - & 30.298 \\
\hline 13 & 329,505 & 587,719 & - & 18,680 \\
\hline 14 & 246,949 & 683,420 & - & 30,253 \\
\hline 15 & 240,239 & $1,398,288$ & - & 22,556 \\
\hline 16 & 359,386 & 244,894 & - & 27,413 \\
\hline Mean & 246,025 & $2,157,802$ & - & 24,470 \\
\hline Std Dev & 68,202 & $1,538,160$ & - & 3,779 \\
\hline $\mathrm{CoV}$ & 28 & 71 & & 15 \\
\hline 958 & 123,238 & $2,779,380$ & & 6,828 \\
\hline$\underset{958}{\text { Mean - }}$ & 122,787 & $-621,578$ & & 17,642 \\
\hline
\end{tabular}


Table 41.

Site 11, Layer Moduli (psi) vs Test Number

\begin{tabular}{|c|c|c|c|c|}
\hline $\begin{array}{c}\text { Test } \\
\text { Number }\end{array}$ & AC Modulus & PCC Modulus & $\begin{array}{c}\text { Base } \\
\text { Modulus }\end{array}$ & $\begin{array}{l}\text { Subgrade } \\
\text { Modulus }\end{array}$ \\
\hline 1 & 230,000 & $1,459,948$ & 11,236 & 14,050 \\
\hline 2 & 230,000 & $3,585,107$ & 1,000 & 150,000 \\
\hline 3 & 230,000 & $4,710,297$ & 3,377 & 109,072 \\
\hline 4 & 230,000 & $2,886,077$ & 1,787 & 30,702 \\
\hline 5 & 230,000 & $10,000,000$ & 2,036 & 94,408 \\
\hline 6 & 230,000 & $7,057,071$ & 73,869 & 21,014 \\
\hline 7 & 230,000 & $9,297,741$ & 143,463 & 22,278 \\
\hline 8 & 230,000 & $1,000,000$ & 83,808 & 17,169 \\
\hline 9 & 230,000 & $4,756,010$ & 10,746 & 30,149 \\
\hline 10 & 230,000 & $4,434,334$ & 13,19 & 19,938 \\
\hline 11 & 230,000 & $2,429,518$ & 55,474 & 27,837 \\
\hline 12 & 230,000 & $2,085,262$ & 39,072 & 14,548 \\
\hline 13 & 230,000 & $9,300,365$ & 3,543 & 150,000 \\
\hline 14 & 230,000 & $6,550,718$ & 4,400 & 52,024 \\
\hline 15 & 230,000 & $9,905,948$ & 2,554 & 62,432 \\
\hline 16 & 230,000 & $3,980,786$ & 10,620 & 24,582 \\
\hline Mean & $-\infty$ & $5,214,948$ & 28,756 & 52,450 \\
\hline Std Dev & -- & $3,093,400$ & 40,841 & 47,349 \\
\hline $\mathrm{CoV}$ & & 59 & 142 & 90 \\
\hline 958 & & $5,589,622$ & 73,798 & 85,557 \\
\hline $\begin{array}{c}\text { Mean - } \\
958\end{array}$ & $--\cdots$ & $-374,674$ & $-45,042$ & $-33,107$ \\
\hline
\end{tabular}


Table 42 .

Site 12, Layer Moduli (psi) vs Test Number

\begin{tabular}{|c|c|c|c|c|}
\hline $\begin{array}{c}\text { Test } \\
\text { Number }\end{array}$ & AC Modulus & PCC Modulus & $\begin{array}{l}\text { Base } \\
\text { Modulus }\end{array}$ & $\begin{array}{l}\text { Subgrade } \\
\text { Modulus }\end{array}$ \\
\hline 1 & 95,278 & $7,000,000$ & - & 20,069 \\
\hline 2 & 105,028 & $7,000,000$ & - & 19,711 \\
\hline 3 & 104,332 & $7,000,000$ & - & 22,304 \\
\hline 4 & 94,364 & $6,837,413$ & & 24,720 \\
\hline 5 & 65,688 & $7,000,000$ & - & 25,622 \\
\hline 6 & 103,644 & $5,964,283$ & - & 28,949 \\
\hline 7 & 110,378 & $5,219,057$ & - & 34,968 \\
\hline 8 & 99,068 & $7,000,000$ & - & 26,067 \\
\hline 9 & 126,508 & $2,279,570$ & - & 26,480 \\
\hline 10 & 98,717 & $3,967,114$ & - & 33,238 \\
\hline 11 & 108,647 & $2,961,488$ & - & 31,095 \\
\hline 12 & 112,511 & $1,790,245$ & - & 37,449 \\
\hline 13 & 110,528 & $2,496,194$ & -+- & 28,462 \\
\hline 14 & 115,565 & $5,272,974$ & - & 22,991 \\
\hline 15 & 101,944 & $6,887,276$ & - & 22,263 \\
\hline 16 & 120,158 & $4,692,772$ & $-\ldots$ & 21,733 \\
\hline Mean & 104,522 & $5,210,524$ & - & 26,633 \\
\hline Std Dev & 13,586 & $1,941,995$ & - & 5,353 \\
\hline $\mathrm{CoV}$ & 13 & 39 & & 20 \\
\hline 958 & 25,549 & $3,509,089$ & & 9,673 \\
\hline $\begin{array}{c}\text { Mean - } \\
958\end{array}$ & 79,973 & $1,701,434$ & 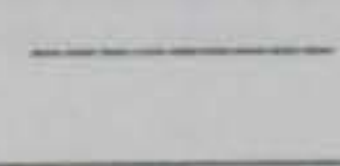 & 16,960 \\
\hline
\end{tabular}


Table 43.

Site 1 , Overlays vs Test Number

\begin{tabular}{|c|c|c|}
\hline Test Number & AC Overlay (in) & PCC Overlay (in) \\
\hline 1 & 3.8 & 12.2 \\
\hline 2 & 5.5 & 13.1 \\
\hline 3 & 6.2 & 13.4 \\
\hline 4 & 4.4 & 12.6 \\
\hline 5 & 4.3 & 12.5 \\
\hline 6 & 4.8 & 12.8 \\
\hline 7 & 4.4 & 12.5 \\
\hline 8 & 4.0 & 12.4 \\
\hline 9 & 4.9 & 12.8 \\
\hline 10 & 4.2 & 12.4 \\
\hline 11 & 4.9 & 12.8 \\
\hline 12 & 5.3 & 13.0 \\
\hline 13 & 4.7 & 12.7 \\
\hline 14 & 5.2 & 12.9 \\
\hline 15 & 5.9 & 13.3 \\
\hline 16 & 5.0 & 12.9 \\
\hline Mean & 4.8 & 12.8 \\
\hline Standard Deviation & 0.7 & 0.3 \\
\hline $\mathrm{CoV}$ & 13.8 & 2.6 \\
\hline 958 & 1.2 & 0.5 \\
\hline Mean +958 & 6.0 & 13.3 \\
\hline
\end{tabular}


Table 44.

Site 2, Overlays vs Test Number

\begin{tabular}{|c|c|c|}
\hline Test Number & AC Overlay (in) & PCC Overlay (in) \\
\hline 1 & 30.3 & 19.5 \\
\hline 2 & 32.1 & 19.7 \\
\hline 3 & 27.9 & 18.5 \\
\hline 4 & 28.1 & 18.7 \\
\hline 5 & 29.4 & 19.2 \\
\hline 6 & 31.6 & 19.8 \\
\hline 7 & 23.6 & 17.1 \\
\hline 8 & 26.5 & 18.2 \\
\hline 9 & 27.6 & 18.4 \\
\hline 10 & 25.1 & 17.6 \\
\hline 11 & 27.9 & 18.6 \\
\hline 12 & 31.8 & 19.9 \\
\hline 13 & 28.6 & 18.8 \\
\hline 14 & 29.6 & 19.2 \\
\hline 15 & 30.0 & 19.4 \\
\hline 16 & 27.1 & 18.2 \\
\hline Mean & 28.6 & 18.8 \\
\hline Standard Deviation & 2.4 & 0.8 \\
\hline $\mathrm{CoV}$ & 8.3 & 4.2 \\
\hline 958 & 4.3 & 1.4 \\
\hline Mean +958 & 32.9 & 20.2 \\
\hline
\end{tabular}


Table 45.

Site 3, Overlays vs Test Number

\begin{tabular}{|c|c|c|}
\hline Test Number & AC Overlay (in) & PCC Overlay (in) \\
\hline 1 & 33.3 & 18.7 \\
\hline 2 & 31.6 & 17.9 \\
\hline 3 & 33.0 & 18.8 \\
\hline 4 & 38.2 & 20.8 \\
\hline 5 & 39.8 & 217 \\
\hline 6 & 37.0 & 20.6 \\
\hline 7 & 32.3 & 18.5 \\
\hline 8 & 33.7 & 18.7 \\
\hline 9 & 29.3 & 16.9 \\
\hline 10 & 34.7 & 19.2 \\
\hline 11 & 30.7 & 17.7 \\
\hline 12 & 24.5 & 15.7 \\
\hline 13 & 24.7 & 15.5 \\
\hline 14 & 33.3 & 18.7 \\
\hline 15 & 31.2 & 18.1 \\
\hline 16 & 36.7 & 20.3 \\
\hline Mean & 32.8 & 18.6 \\
\hline Standard Deviation & 4.1 & 1.7 \\
\hline $\mathrm{CoV}$ & 12.6 & 9.2 \\
\hline 958 & 7.4 & 3.1 \\
\hline Mean +958 & 40.2 & 21.7 \\
\hline
\end{tabular}


Table 46 .

Site 4, Overlays vs Test Number

\begin{tabular}{|c|c|c|}
\hline Test Number & AC Overlay (in) & PCC Overlay (in) \\
\hline 1 & 20.0 & 23.5 \\
\hline 2 & 20.4 & 23.6 \\
\hline 3 & 20.0 & 23.5 \\
\hline 4 & 19.2 & 23.1 \\
\hline 5 & 19.1 & 23.1 \\
\hline 6 & 18.7 & 23.0 \\
\hline 7 & 20.6 & 23.7 \\
\hline 8 & 19.1 & 23.1 \\
\hline 9 & 24.8 & 25.3 \\
\hline 10 & 25.9 & 25.7 \\
\hline 11 & 28.6 & 26.6 \\
\hline 12 & 25.0 & 25.3 \\
\hline 13 & 25.0 & 25.3 \\
\hline 14 & 18.0 & 22.7 \\
\hline 15 & 18.8 & 23 \\
\hline 16 & 4.3 & 25.1 \\
\hline Mean & 21.7 & 24.1 \\
\hline Standard Deviation & 3.3 & 1.2 \\
\hline $\mathrm{Cov}$ & 15.2 & 5.1 \\
\hline 958 & 6.0 & 2.2 \\
\hline Mean +958 & 27.7 & 26.3 \\
\hline
\end{tabular}


Table 47.

Site 5, Overlays vs Test Number

\begin{tabular}{|c|c|c|}
\hline Test Number & AC Overlay (in) & PCC Overlay (in) \\
\hline 1 & 11.9 & - \\
\hline 2 & 12.1 & $\longrightarrow$ \\
\hline 3 & 12.2 & - \\
\hline 4 & 10.4 & $\longrightarrow$ \\
\hline 5 & 13.1 & $\longrightarrow$ \\
\hline 6 & 11.0 & $\longrightarrow$ \\
\hline 7 & 12.8 & - \\
\hline 8 & 14.9 & - \\
\hline 9 & 13.5 & - \\
\hline 10 & 15.2 & - \\
\hline 11 & 15.7 & - \\
\hline 12 & 14.2 & - \\
\hline 13 & 15.6 & - \\
\hline 14 & 12.9 & - \\
\hline 15 & 13.0 & - \\
\hline 16 & 12.5 & - \\
\hline Mean & 13.2 & - \\
\hline Standard Deviation & 1.6 & - \\
\hline $\mathrm{CoV}$ & 12.0 & - \\
\hline 958 & 2.9 & - \\
\hline Mean +958 & 16.1 & - \\
\hline
\end{tabular}


Table 48.

Site 6 , Overlays vs Test Number

\begin{tabular}{|c|c|c|}
\hline Test Number & AC Overlay (in) & PCC Overlay (in) \\
\hline 1 & 19.4 & - \\
\hline 2 & 19.5 & - \\
\hline 3 & 12.4 & 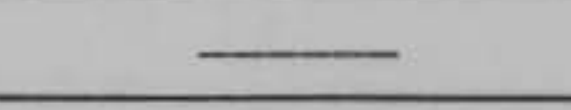 \\
\hline 4 & 14.1 & 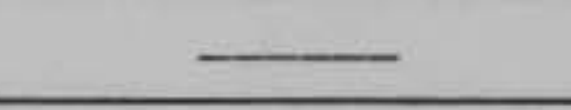 \\
\hline 5 & 13.3 & - \\
\hline 6 & 0.0 & - \\
\hline 7 & 11.0 & - \\
\hline 8 & 11.5 & - \\
\hline 9 & 17.3 & - \\
\hline 10 & 13.6 & - \\
\hline 11 & 18.0 & - \\
\hline 12 & 12.5 & - \\
\hline 13 & 14.0 & - \\
\hline 14 & 10.4 & - \\
\hline 15 & 12.7 & - \\
\hline 16 & 10.1 & $\ldots$ \\
\hline Mean & 13.1 & $-\cdots$ \\
\hline Standard Deviation & 4.6 & - \\
\hline $\mathrm{Cov}$ & 35.2 & $-\ldots$ \\
\hline 958 & 8.3 & - \\
\hline Mean +958 & 21.4 & - \\
\hline
\end{tabular}


Table 49 .

Site 7 , Overlays vs Test Number

\begin{tabular}{|c|c|c|}
\hline Test Number & AC Overlay (in) & PCC Overlay (in) \\
\hline 1 & 0.0 & - \\
\hline 2 & 0.0 & - \\
\hline 3 & 0.0 & - \\
\hline 4 & 17.0 & - \\
\hline 5 & 0.0 & $\longrightarrow$ \\
\hline 6 & 0.0 & - \\
\hline 7 & 0.0 & $\longrightarrow$ \\
\hline 8 & 0.0 & - \\
\hline 9 & 0.0 & - \\
\hline 10 & 0.0 & - \\
\hline 11 & 0.0 & - \\
\hline 12 & 0.0 & - \\
\hline 13 & 0.0 & - \\
\hline 14 & 0.0 & - \\
\hline 15 & 0.0 & - \\
\hline 16 & 0.0 & - \\
\hline Mean & 1.6 & -- \\
\hline Standard Deviation & 4.2 & -- \\
\hline $\mathrm{CoV}$ & 400.0 & $\longrightarrow$ \\
\hline 958 & 7.6 & - \\
\hline Mean $+95 \%$ & 9.2 & - \\
\hline
\end{tabular}


Table 50.

Site 8 , Overlays vs Test Number

\begin{tabular}{|c|c|c|}
\hline Test Number & AC Overlay (in) & PCC Overlay (in) \\
\hline 1 & 11.7 & - \\
\hline 2 & 10.8 & - \\
\hline 3 & 11.7 & - \\
\hline 4 & 11.3 & - \\
\hline 5 & 11.0 & - \\
\hline 6 & 11.0 & - \\
\hline 7 & 10.7 & - \\
\hline 8 & 11.7 & - \\
\hline 9 & 13.0 & - \\
\hline 10 & 12.9 & - \\
\hline 11 & 12.5 & - \\
\hline 12 & 13.1 & - \\
\hline 13 & 13.1 & - \\
\hline 14 & 13.2 & - \\
\hline 15 & 12.3 & -- \\
\hline 16 & 11.8 & - \\
\hline Mean & 12.0 & $\ldots$ \\
\hline Standard Deviation & 0.9 & - \\
\hline $\mathrm{CoV}$ & 7.4 & - \\
\hline $95 \%$ & 1.6 & - \\
\hline Mean +958 & 13.6 & - \\
\hline
\end{tabular}


Table 51.

Site 9, Overlays vs Test Number

\begin{tabular}{|c|c|c|}
\hline Test Number & AC Overlay (in) & PCC Overlay (in) \\
\hline 1 & 32.2 & 21.6 \\
\hline 2 & 30.7 & 21.0 \\
\hline 3 & 31.3 & 21.3 \\
\hline 4 & 29.9 & 20.9 \\
\hline 5 & 29.7 & 20.6 \\
\hline 6 & 29.1 & 20.4 \\
\hline 7 & 28.0 & 19.9 \\
\hline 8 & 31.3 & 21.3 \\
\hline 9 & 31.1 & 21.2 \\
\hline 10 & 29.1 & 20.4 \\
\hline 11 & 32.1 & 21.6 \\
\hline 12 & 29.6 & 20.7 \\
\hline 13 & 33.4 & 22.1 \\
\hline 14 & 30.6 & 21.2 \\
\hline 15 & 29.7 & 20.4 \\
\hline 16 & 23.8 & 18.2 \\
\hline Mean & 30.1 & 20.8 \\
\hline Standard Deviation & 2.2 & 0.9 \\
\hline $\mathrm{CoV}$ & 7.2 & 4.3 \\
\hline 958 & 4.0 & 1.6 \\
\hline Mean +958 & 34.1 & 22.4 \\
\hline
\end{tabular}


Table 52.

Site 10, Overlays vs Test Number

\begin{tabular}{|c|c|c|}
\hline Test Number & AC Overlay (in) & PCC Overlay (in) \\
\hline 1 & 23.7 & 18.0 \\
\hline 2 & 0.0 & 0.0 \\
\hline 3 & 16.1 & 14.9 \\
\hline 4 & 10.2 & 12.5 \\
\hline 5 & 20.7 & 17 \\
\hline 6 & 27.8 & 19.7 \\
\hline 7 & 26.7 & 19.3 \\
\hline 8 & 24.3 & 18.2 \\
\hline 9 & 21.9 & 17.3 \\
\hline 10 & 13.4 & 13.5 \\
\hline 11 & 20.6 & 16.7 \\
\hline 12 & 19.1 & 16.4 \\
\hline 13 & 9.3 & 11.8 \\
\hline 14 & 5.1 & 10.3 \\
\hline 15 & 15.6 & 14.6 \\
\hline 16 & 0.0 & 0.0 \\
\hline Mean & 15.9 & 13.8 \\
\hline Standard Deviation & 8.9 & 6.0 \\
\hline $\mathrm{CoV}$ & 55.9 & 43.6 \\
\hline 958 & 16.1 & 10.8 \\
\hline Mean +958 & 32.0 & 24.6 \\
\hline
\end{tabular}


Table 53.

Site 11, Overlays vs Test Number

\begin{tabular}{|c|c|c|}
\hline Test Number & AC Overlay (in) & PCC Overlay (in) \\
\hline 1 & 28.6 & 18.4 \\
\hline 2 & 24.7 & 22.9 \\
\hline 3 & 20.4 & 20.6 \\
\hline 4 & 33.2 & 22.0 \\
\hline 5 & 27.8 & 24.5 \\
\hline 6 & 39.3 & 23.4 \\
\hline 7 & 40.8 & 24.1 \\
\hline 8 & 14.6 & 12.7 \\
\hline 9 & 31.7 & 21.2 \\
\hline 10 & 37.7 & 22.5 \\
\hline 11 & 21.9 & 16.7 \\
\hline 12 & 30.2 & 19.1 \\
\hline 13 & 24.1 & 22.6 \\
\hline 14 & 26.6 & 22.3 \\
\hline 15 & 27.8 & 24.5 \\
\hline 16 & 33.1 & 21.2 \\
\hline Mean & 28.9 & 21.2 \\
\hline Standard Deviation & 7.1 & 3.1 \\
\hline $\mathrm{CoV}$ & 24.4 & 14.9 \\
\hline 958 & 12.8 & 5.6 \\
\hline Mean +958 & 41.7 & 26.8 \\
\hline
\end{tabular}


Table 54.

Site 12, Overlays vs Test Number

\begin{tabular}{|c|c|c|}
\hline Test Number & AC Overlay (in) & PCC Overlay (in) \\
\hline 1 & 34.8 & 24.1 \\
\hline 2 & 35.0 & 24.2 \\
\hline 3 & 33.0 & 23.5 \\
\hline 4 & 31.6 & 23.1 \\
\hline 5 & 31.4 & 23.0 \\
\hline 6 & 27.7 & 21.7 \\
\hline 7 & 22.8 & 20.1 \\
\hline 8 & 31.2 & 22.9 \\
\hline 9 & 17.4 & 17.4 \\
\hline 10 & 20.5 & 19.0 \\
\hline 11 & 18.0 & 17.8 \\
\hline 12 & 10.1 & 14.9 \\
\hline 13 & 0.0 & 0.0 \\
\hline 14 & 29.6 & 22.2 \\
\hline 15 & 33.2 & 23.6 \\
\hline 16 & 29.0 & 21.9 \\
\hline Mean & 25.3 & 20.0 \\
\hline Standard Deviation & 9.9 & 6.0 \\
\hline $\mathrm{CoV}$ & 39.1 & 30.0 \\
\hline 958 & 17.9 & 10.8 \\
\hline Mean +958 & 43.2 & 30.8 \\
\hline
\end{tabular}


Table 55.

Allowable Gross Load (AGL) and Allowable

Passes vs Test Number, Sites 1 and 2

\begin{tabular}{|c|c|c|c|c|}
\hline \multirow{2}{*}{$\begin{array}{c}\text { Test } \\
\text { Number }\end{array}$} & \multicolumn{2}{|c|}{ Site 1} & \multicolumn{2}{|c|}{ Site 2} \\
\hline & $\begin{array}{c}\text { AGL } \\
\text { (Kips) }\end{array}$ & Passes & $\begin{array}{l}\text { AGL } \\
\text { (Kips) }\end{array}$ & Passes \\
\hline 1 & 385 & 12,680 & 179 & 23 \\
\hline 2 & 372 & 8,700 & 177 & 22 \\
\hline 3 & 368 & 7,556 & 190 & 32 \\
\hline 4 & 380 & 10,999 & 188 & 30 \\
\hline 5 & 381 & 11,205 & 182 & 25 \\
\hline 6 & 377 & 10,098 & 175 & 21 \\
\hline 7 & 380 & 11,134 & 205 & 52 \\
\hline 8 & 383 & 12,062 & 193 & 36 \\
\hline 9 & 377 & 10,027 & 191 & 33 \\
\hline 10 & 382 & 11,701 & 199 & 44 \\
\hline 11 & 377 & 9,889 & 189 & 32 \\
\hline 12 & 374 & 9,088 & 175 & 21 \\
\hline 13 & 378 & 10,463 & 187 & 30 \\
\hline 14 & 375 & 9,379 & 182 & 26 \\
\hline 15 & 370 & 8,081 & 180 & 24 \\
\hline 16 & 376 & 9,697 & 192 & 35 \\
\hline Mean & 377 & 10,172 & 186 & 30 \\
\hline Std Dev & 4.7 & 1,425 & 8.6 & 8.6 \\
\hline $\mathrm{CoV}$ & 1.2 & 14.0 & 4.6 & 28.3 \\
\hline 958 & 8.5 & 2,575 & 15.6 & 15.5 \\
\hline $\begin{array}{c}\text { Mean - } \\
958\end{array}$ & 368 & 7,597 & 170 & 14.5 \\
\hline
\end{tabular}


Table 56.

Allowable Gross Load (AGL) and Allowable

Passes vs Test Number, Sites 3 and 4

\begin{tabular}{|c|c|c|c|c|}
\hline \multirow{2}{*}{$\begin{array}{c}\text { Test } \\
\text { Number }\end{array}$} & \multicolumn{2}{|c|}{ Site 3} & \multicolumn{2}{|c|}{ Site 4} \\
\hline & $\begin{array}{c}\text { AGL } \\
\text { (Kips) }\end{array}$ & Passes & $\begin{array}{c}\text { AGL } \\
\text { (Kips) }\end{array}$ & Passes \\
\hline 1 & 134 & 6 & 284 & 589 \\
\hline 2 & 142 & 7 & 283 & 558 \\
\hline 3 & 134 & 6 & 284 & 586 \\
\hline 4 & 117 & 4 & 288 & 658 \\
\hline 5 & 110 & 3 & 288 & 667 \\
\hline 6 & 118 & 4 & 290 & 698 \\
\hline 7 & 136 & 6 & 282 & 544 \\
\hline 8 & 134 & 6 & 288 & 664 \\
\hline 9 & 152 & 10 & 264 & 319 \\
\hline 10 & 130 & 5 & 260 & 280 \\
\hline 11 & 143 & 8 & 251 & 210 \\
\hline 12 & 167 & 16 & 264 & 314 \\
\hline 13 & 170 & 18 & 264 & 312 \\
\hline 14 & 134 & 6 & 293 & 764 \\
\hline 15 & 140 & 7 & 290 & 692 \\
\hline 16 & 120 & 4 & 266 & 335 \\
\hline Mean & 136 & 7.3 & 277 & 511 \\
\hline Std Dev & 16.6 & 4.2 & 13.5 & 183 \\
\hline $\mathrm{CoV}$ & 12.2 & 57.8 & 4.9 & 35.9 \\
\hline 958 & 30.0 & 7.6 & 24.4 & 332 \\
\hline $\begin{array}{c}\text { Mean - } \\
958\end{array}$ & 106 & 0 & 253 & 179 \\
\hline
\end{tabular}


Table 57.

Allowable Gross Load (AGL) and Allowable

Passes vs Test Number, Sites 5 and 6

\begin{tabular}{|c|c|c|c|c|}
\hline \multirow{2}{*}{$\begin{array}{c}\text { Test } \\
\text { Number }\end{array}$} & \multicolumn{2}{|c|}{ Site 5} & \multicolumn{2}{|c|}{ Site 6} \\
\hline & $\begin{array}{c}\text { AGL } \\
\text { (Kips) }\end{array}$ & Passes & $\begin{array}{c}\text { AGL } \\
\text { (Kips) }\end{array}$ & Passes \\
\hline 1 & 264 & 219 & 136 & 80 \\
\hline 2 & 216 & 44 & 129 & 117 \\
\hline 3 & 212 & 39 & 215 & 1,231 \\
\hline 4 & 239 & 82 & 176 & 1,087 \\
\hline 5 & 221 & 50 & 188 & 2,157 \\
\hline 6 & 238 & 74 & 616 & $4,000,000$ \\
\hline 7 & 231 & 67 & 229 & 6,776 \\
\hline 8 & 190 & 58 & 237 & 4,104 \\
\hline 9 & 199 & 29 & 153 & 455 \\
\hline 10 & 189 & 19 & 210 & 397 \\
\hline 11 & 183 & 21 & 152 & 90 \\
\hline 12 & 195 & 24 & 215 & 1,206 \\
\hline 13 & 162 & 69 & 185 & 1,171 \\
\hline 14 & 214 & 42 & 262 & 1,991 \\
\hline 15 & 203 & 32 & 207 & 1,484 \\
\hline 16 & 218 & 46 & 268 & 4,379 \\
\hline Mean & 211 & 57 & 224 & 251,670 \\
\hline Std Dev & 25.1 & 47.3 & 112.5 & 999,556 \\
\hline $\mathrm{CoV}$ & 11.9 & 82.7 & 5.03 & 397 \\
\hline 958 & 45.4 & 85.5 & 203 & $1,806,149$ \\
\hline $\begin{array}{c}\text { Mean - } \\
958\end{array}$ & 166 & -28 & 20 & $-1,554,478$ \\
\hline
\end{tabular}


Table 58.

Allowable Gross Load (AGL) and Allowable

Passes vs Test Number, Sites 7 and 8

\begin{tabular}{|c|c|c|c|c|}
\hline \multirow{2}{*}{$\begin{array}{c}\text { Test } \\
\text { Number }\end{array}$} & \multicolumn{2}{|c|}{ Site 7} & \multicolumn{2}{|c|}{ Site 8} \\
\hline & $\begin{array}{c}\text { AGL } \\
\text { (Kips) }\end{array}$ & Passes & $\begin{array}{c}\text { AGL } \\
\text { (Kips) }\end{array}$ & Passes \\
\hline 1 & 1,934 & $4,000,000$ & 180 & 2,041 \\
\hline 2 & 1,483 & $4,000,000$ & 194 & 2,968 \\
\hline 3 & 539 & 494,245 & 179 & 1,972 \\
\hline 4 & 151 & 857 & 183 & 2,199 \\
\hline 5 & 892 & $4,000,000$ & 183 & 2,229 \\
\hline 6 & 761 & $2,770,255$ & 181 & 2,083 \\
\hline 7 & 2,782 & $4,000,000$ & 183 & 2,217 \\
\hline 8 & 513 & 385,014 & 173 & 1,710 \\
\hline 9 & 1,334 & $4,000,000$ & 154 & 923 \\
\hline 10 & 1,730 & $4,000,000$ & 151 & 849 \\
\hline 11 & 1,163 & $4,000,000$ & 165 & 1,336 \\
\hline 12 & 1,765 & $4,000,000$ & 152 & 879 \\
\hline 13 & 1,842 & $4,000,000$ & 158 & 1,065 \\
\hline 14 & 1,678 & $4,000,000$ & 157 & 1,024 \\
\hline 15 & 2,266 & $4,000,000$ & 165 & 1,319 \\
\hline 16 & 2,535 & $4,000,000$ & 187 & 2,472 \\
\hline Mean & 1,460 & $3,228,148$ & 171 & 1705 \\
\hline Std Dev & 753 & $1,490,676$ & 14 & 657 \\
\hline $\mathrm{CoV}$ & 51.6 & 46.2 & 8.2 & 38.5 \\
\hline 958 & 1,361 & $2,693,579$ & 25.3 & 1,187 \\
\hline $\begin{array}{c}\text { Mean - } \\
958\end{array}$ & 99 & 534,569 & 145 & 518 \\
\hline
\end{tabular}


Table 59.

Allowable Gross Load (AGL) and Allowable

Passes vs Test Number, Sites 9 and 10

\begin{tabular}{|c|c|c|c|c|}
\hline \multirow{2}{*}{$\begin{array}{c}\text { Test } \\
\text { Number }\end{array}$} & \multicolumn{2}{|c|}{ Site 9} & \multicolumn{2}{|c|}{ Site 10} \\
\hline & $\begin{array}{c}\text { AGL } \\
\text { (Kips) }\end{array}$ & Passes & $\begin{array}{c}\text { AGL } \\
\text { (Kips) }\end{array}$ & Passes \\
\hline 1 & 166 & 16 & 185 & 29 \\
\hline 2 & 172 & 19 & 491 & 326,765 \\
\hline 3 & 168 & 17 & 290 & 700 \\
\hline 4 & 173 & 19 & 396 & 18,179 \\
\hline 5 & 177 & 22 & 212 & 64 \\
\hline 6 & 178 & 23 & 169 & 17 \\
\hline 7 & 185 & 28 & 171 & 18 \\
\hline 8 & 168 & 17 & 197 & 40 \\
\hline 9 & 169 & 17 & 218 & 77 \\
\hline 10 & 179 & 23 & 365 & 7,059 \\
\hline 11 & 165 & 15 & 245 & 177 \\
\hline 12 & 175 & 21 & 236 & 134 \\
\hline 13 & 160 & 13 & 446 & 81,986 \\
\hline 14 & 170 & 18 & 472 & 183,453 \\
\hline 15 & 179 & 23 & 299 & 918 \\
\hline 16 & 204 & 50 & 801 & $4,000,000$ \\
\hline Mean & 174 & 21.3 & 324 & 288,726 \\
\hline Std Dev & 10.1 & 8.5 & 168 & 993,772 \\
\hline $\mathrm{CoV}$ & 5.8 & 40.0 & 52 & 344 \\
\hline 958 & 18.3 & 15.4 & 303 & $1,795,697$ \\
\hline $\begin{array}{c}\text { Mean - } \\
958\end{array}$ & 156 & 6 & 21 & $-1,506,971$ \\
\hline
\end{tabular}


Table 60 .

Allowable Gross Load (AGL) and Allowable

Passes vs Test Number Sites 11 and 12

\begin{tabular}{|c|c|c|c|c|}
\hline \multirow{2}{*}{$\begin{array}{c}\text { Test } \\
\text { Number }\end{array}$} & \multicolumn{2}{|c|}{ Site 11} & \multicolumn{2}{|c|}{ Site 12} \\
\hline & $\begin{array}{c}\text { AGL } \\
\text { (Kips) }\end{array}$ & Passes & $\begin{array}{c}\text { AGL } \\
\text { (Kips) }\end{array}$ & Passes \\
\hline 1 & 157 & 12 & 145 & 8 \\
\hline 2 & 92 & 2 & 146 & 8 \\
\hline 3 & 108 & 3 & 151 & 10 \\
\hline 4 & 104 & 2 & 156 & 12 \\
\hline 5 & 82 & 1 & 157 & 12 \\
\hline 6 & 121 & 4 & 175 & 21 \\
\hline 7 & 122 & 4 & 198 & 42 \\
\hline 8 & 317 & 1,594 & 158 & 12 \\
\hline 9 & 118 & 4 & 266 & 339 \\
\hline 10 & 114 & 3 & 217 & 75 \\
\hline 11 & 190 & 33 & 244 & 172 \\
\hline 12 & 166 & 13 & 332 & 2,554 \\
\hline 13 & 94 & 2 & 308 & $4,000,000$ \\
\hline 14 & 101 & 2 & 173 & 19 \\
\hline 15 & 84 & 1 & 152 & 10 \\
\hline 16 & 121 & 4 & 179 & 24 \\
\hline Mean & 131 & 105 & 197 & 250,207 \\
\hline Std Dev & 58 & 397 & 60 & 999,945 \\
\hline $\mathrm{CoV}$ & 44.3 & 377 & 30 & 400 \\
\hline 958 & 104 & 717 & 108 & $1,806,852$ \\
\hline $\begin{array}{c}\text { Mean - } \\
958\end{array}$ & 26 & -612 & 89 & $-1,556,645$ \\
\hline
\end{tabular}




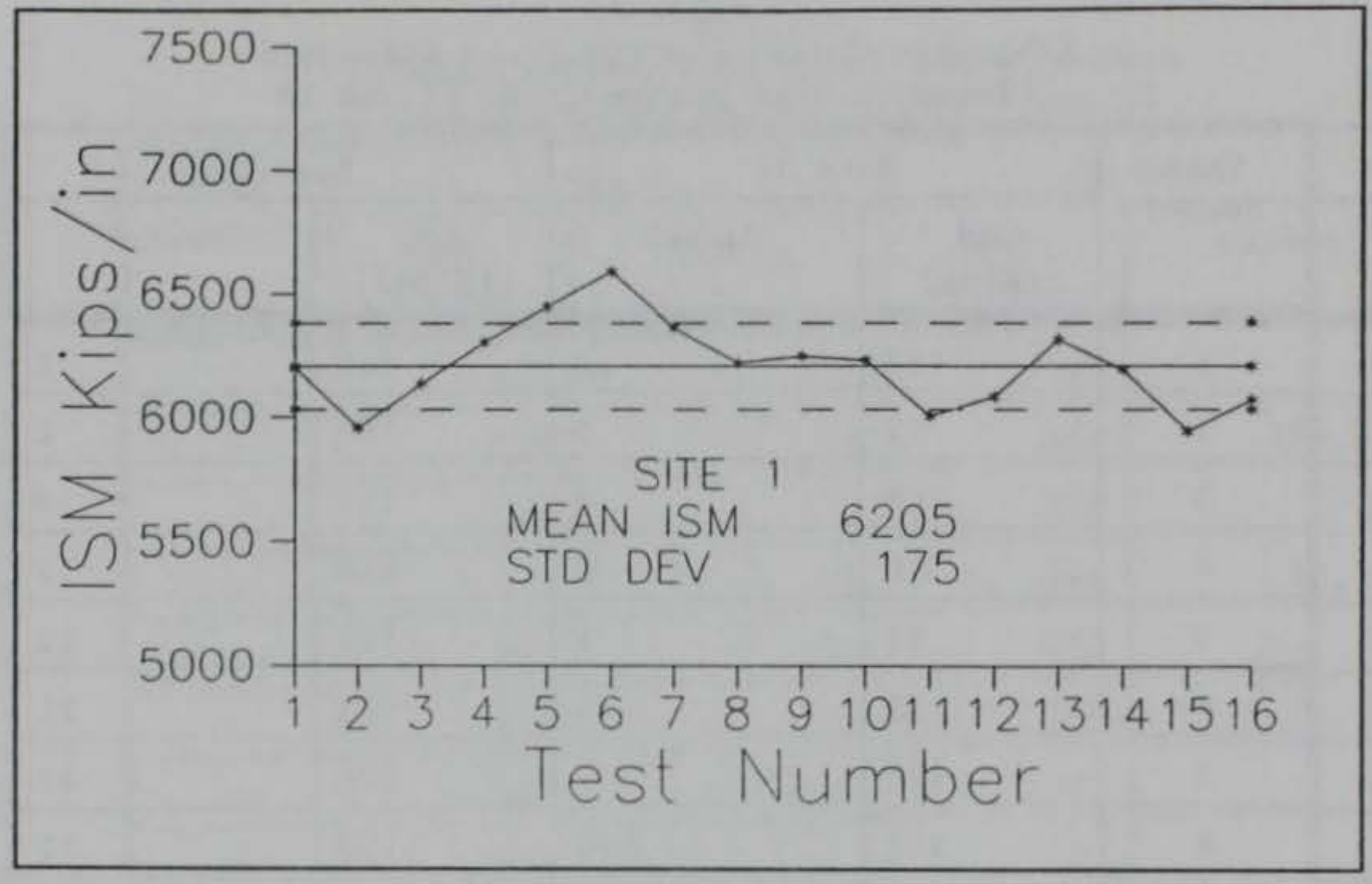

Figure 5. Site 1, ISM vs Test Number

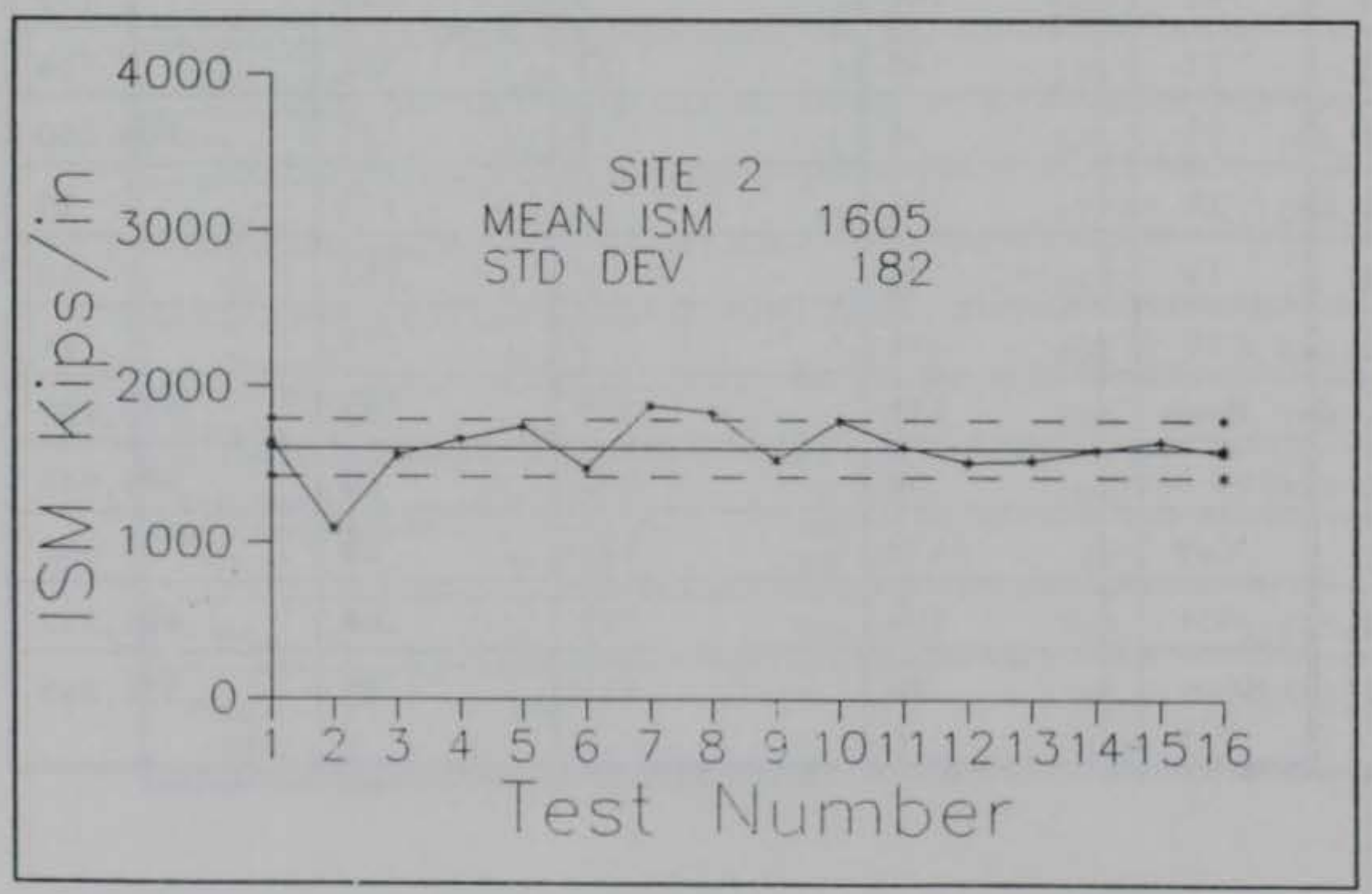

Figure 6. Site 2, ISM vs Test Number 


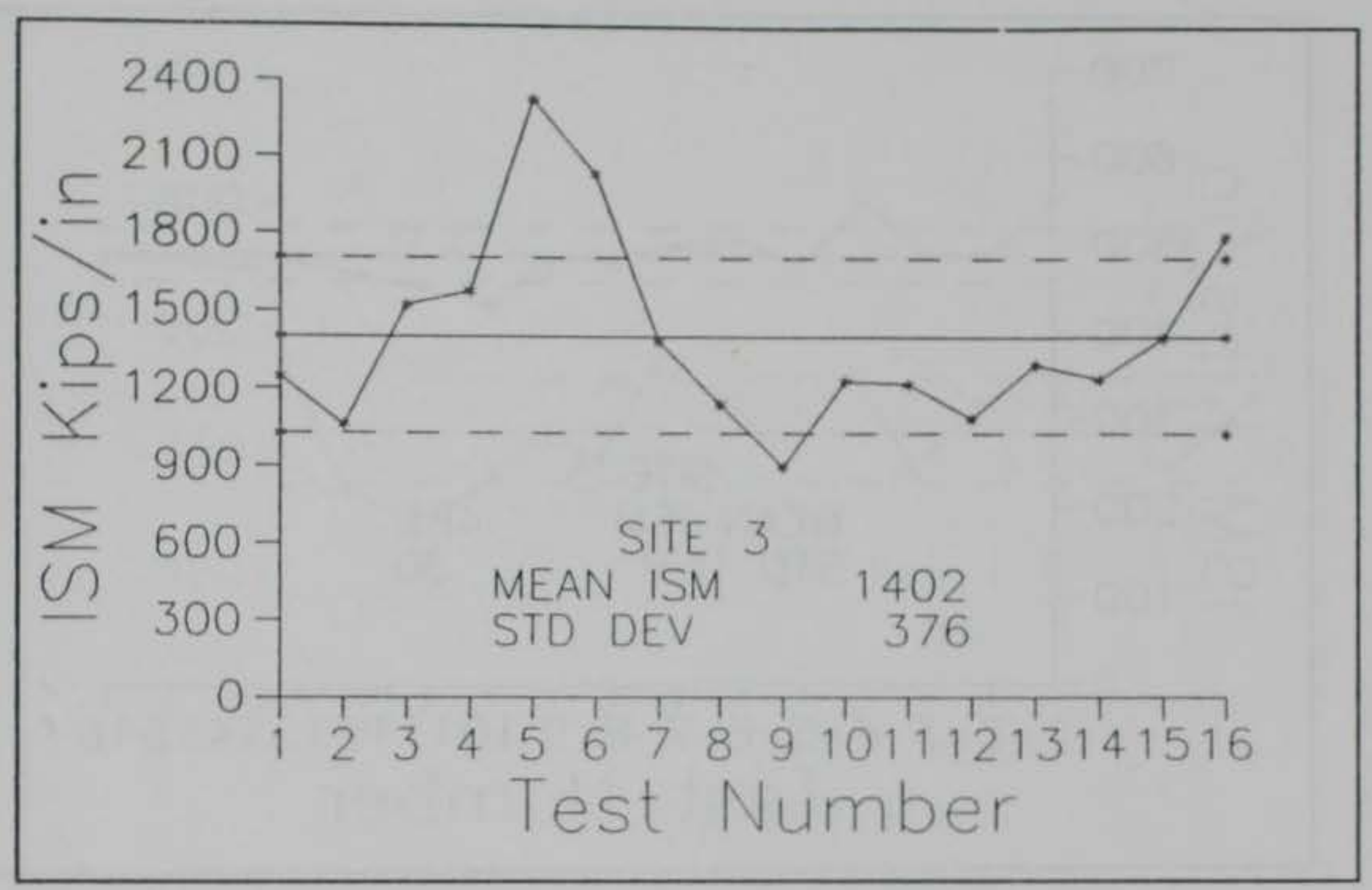

Figure 7. Site 3, ISM vs Test Number

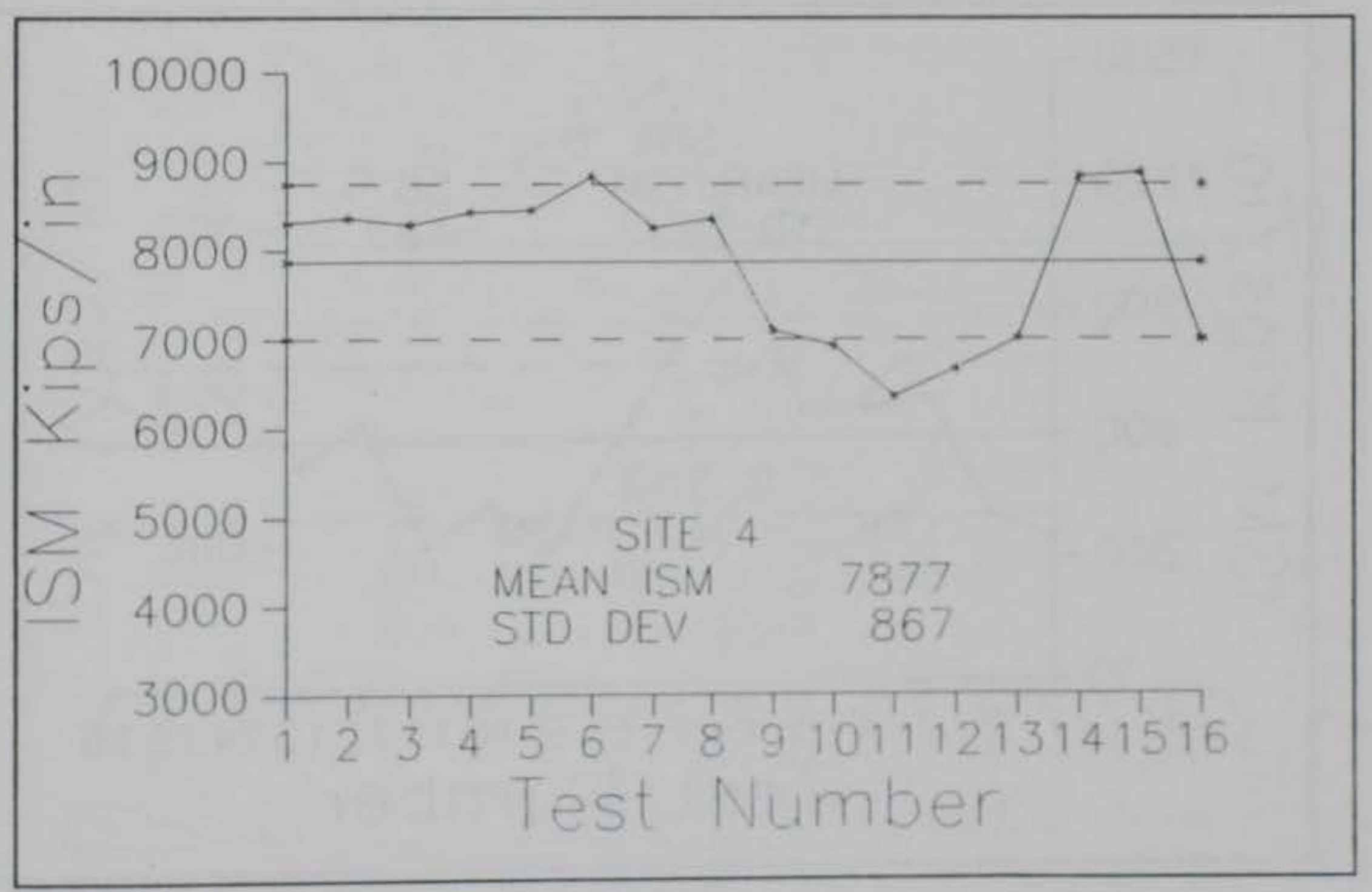

Figure 8. Site 4, ISM vs Test Number 


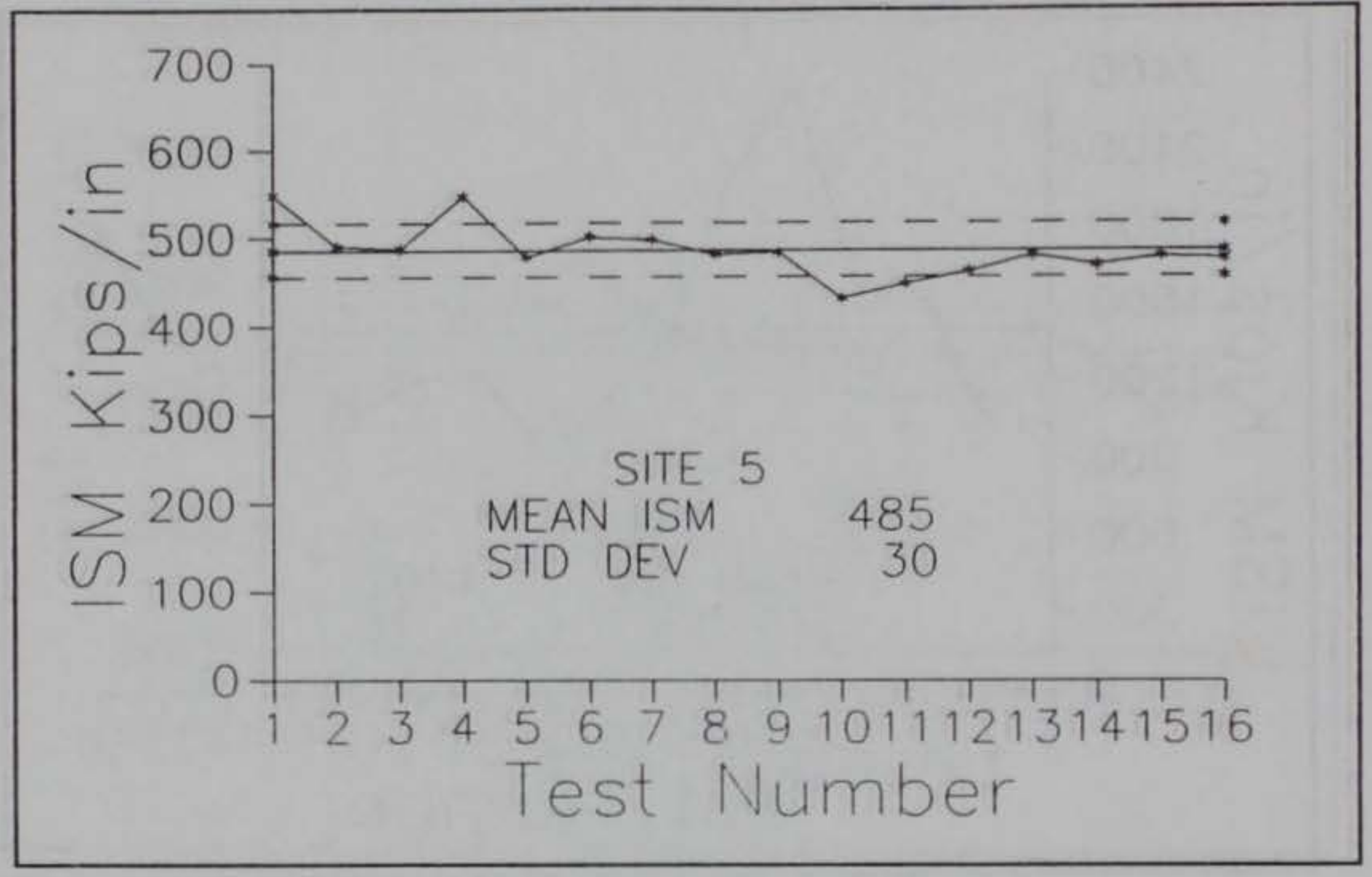

Figure 9. Site 5, ISM vs Test Number

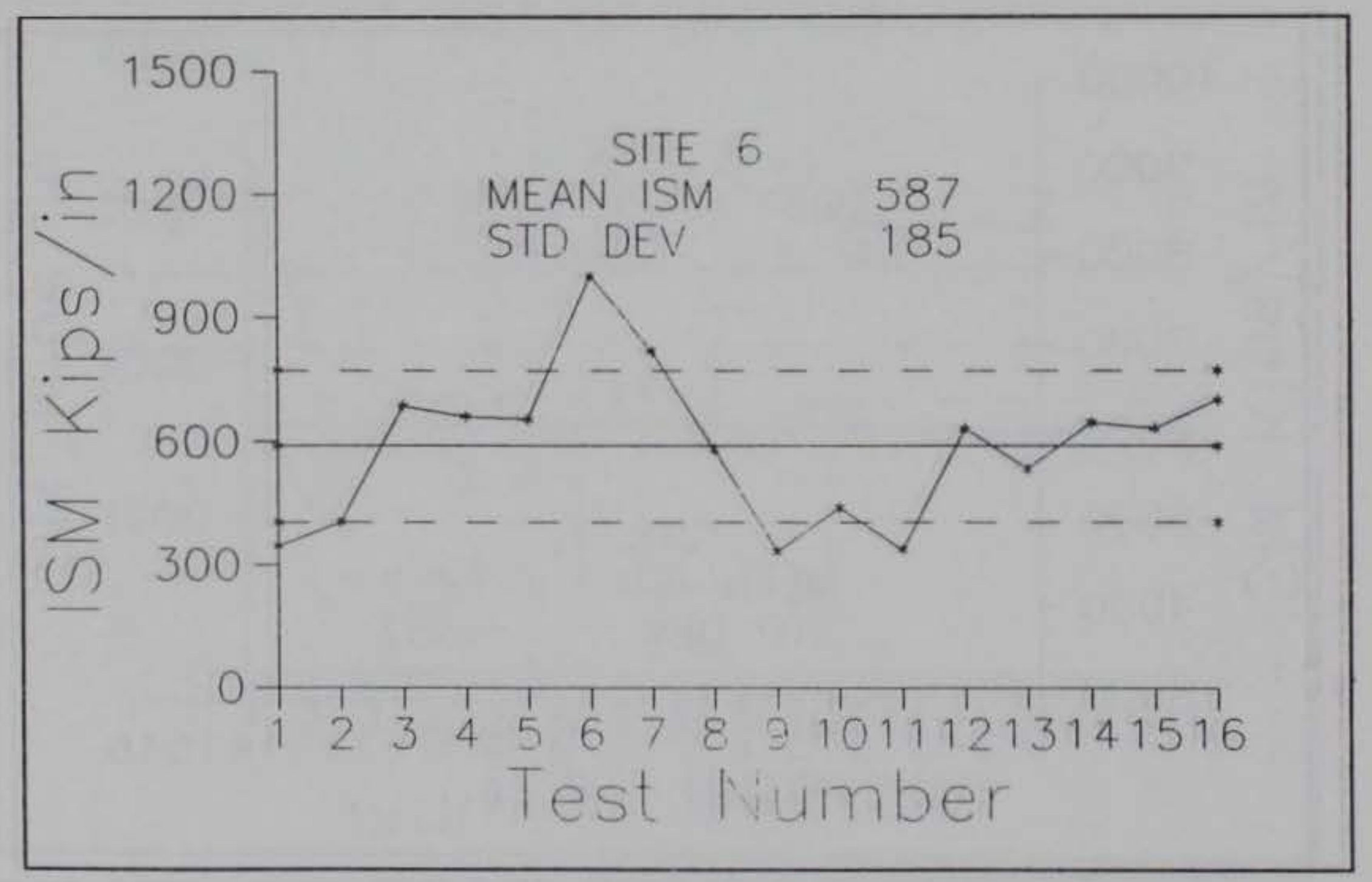

Figure 10. Site 6 , ISM vs Test Number 


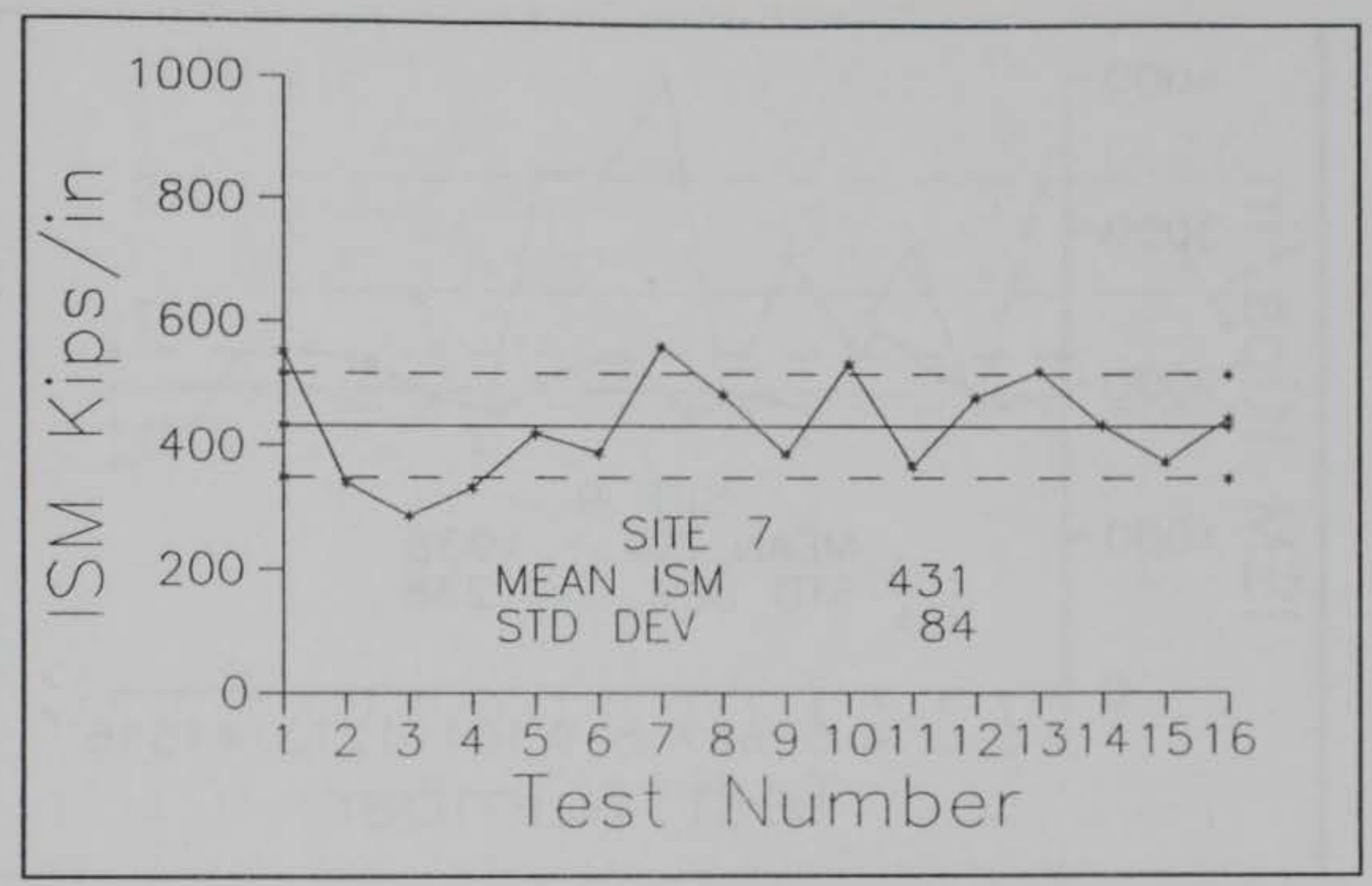

Figure 11. Site 7, ISM vs Test Number

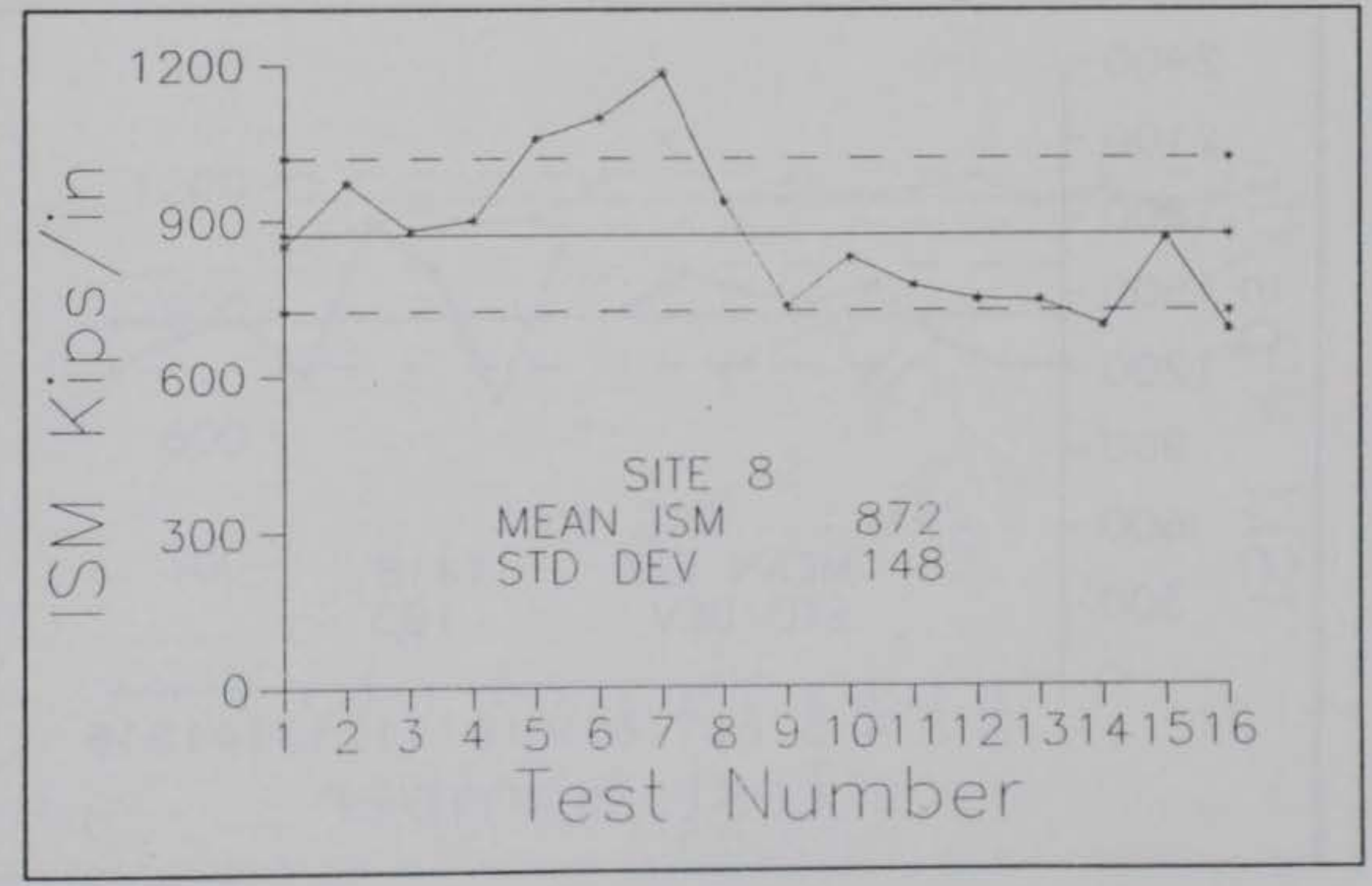

Figure 12. Site 8, ISM vs Test Number 


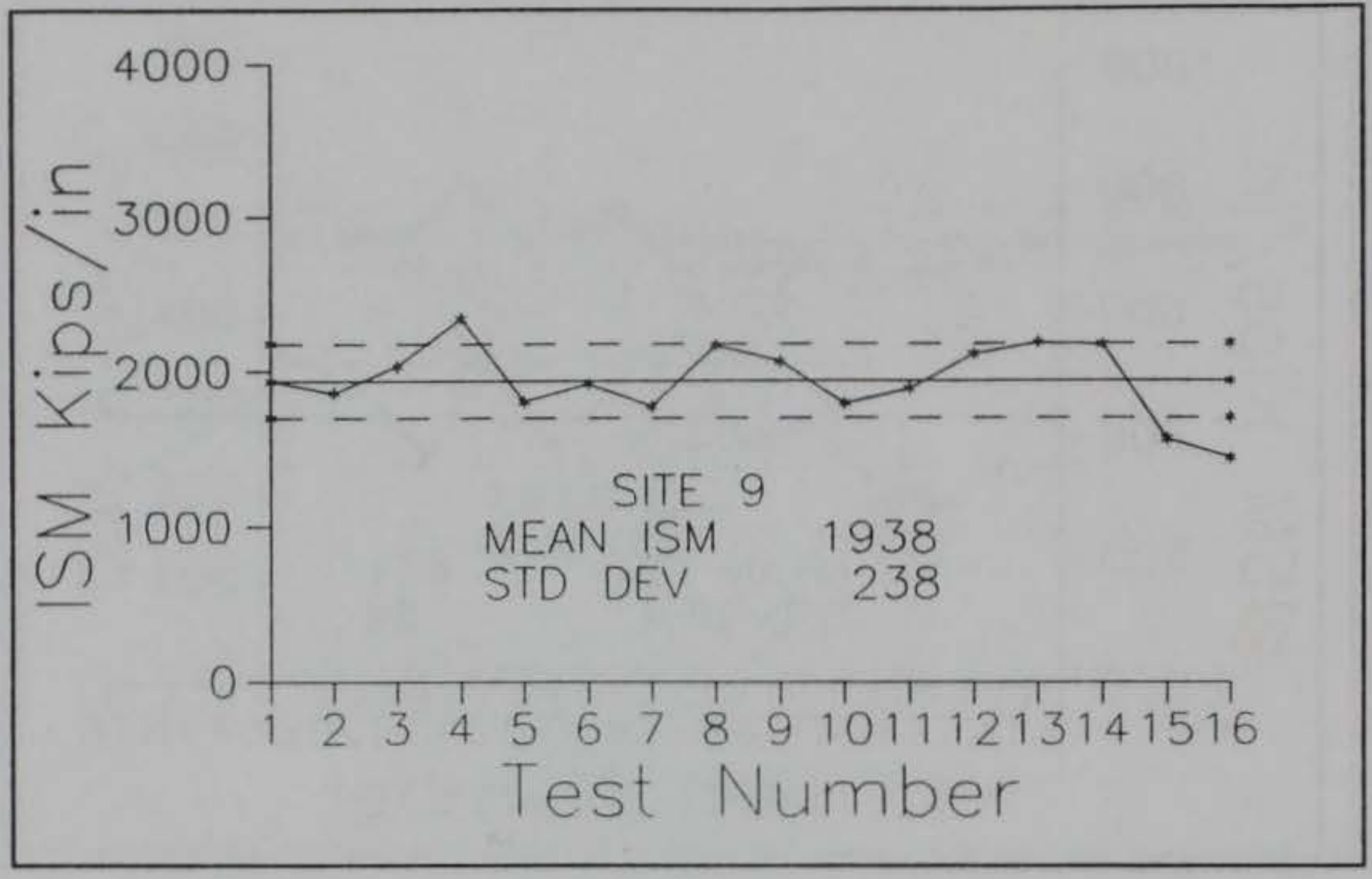

Figure 13. Site 9, ISM vs Test Number

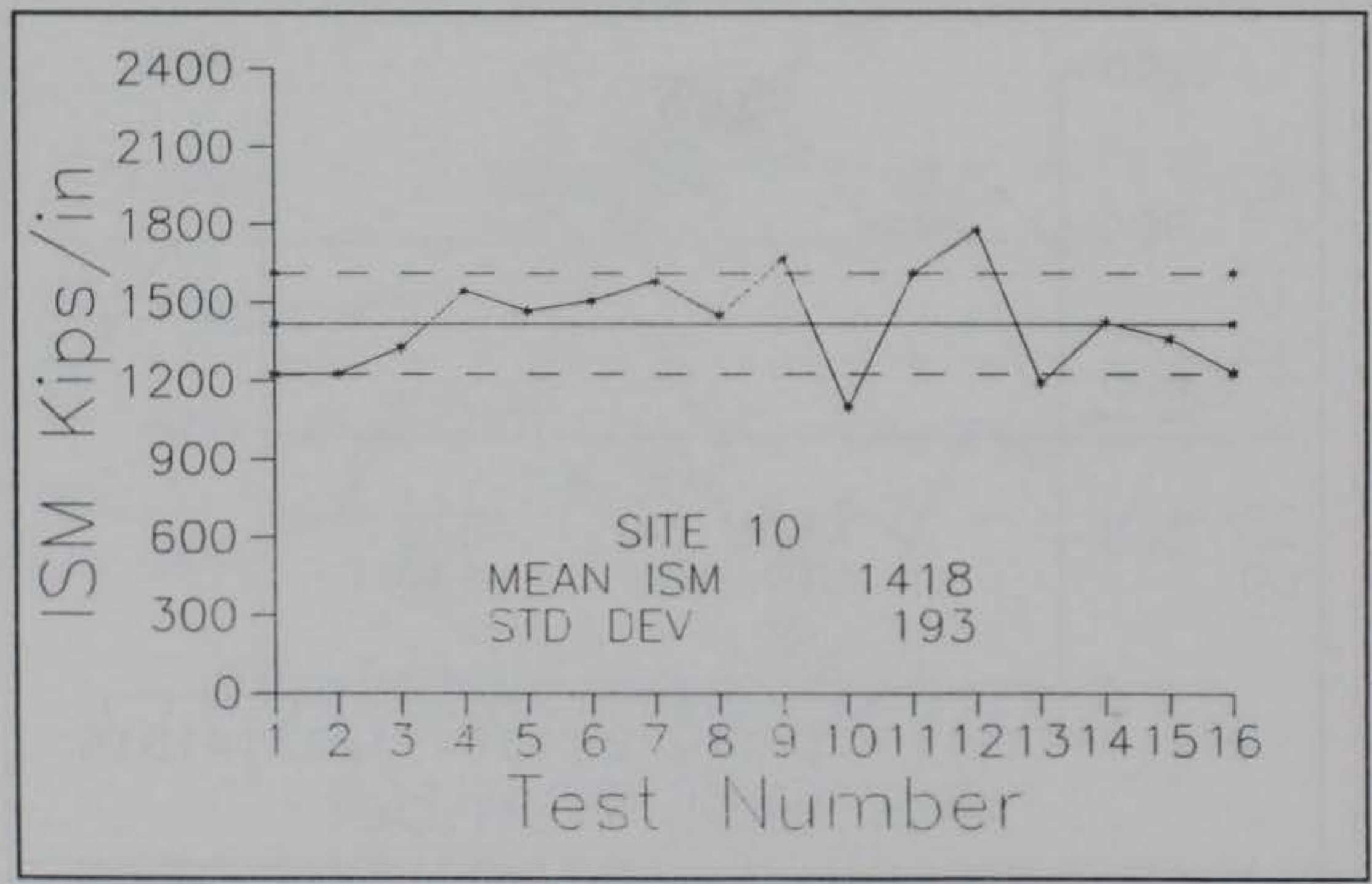

Figure 14. Site 10 , ISM vs Test Number 


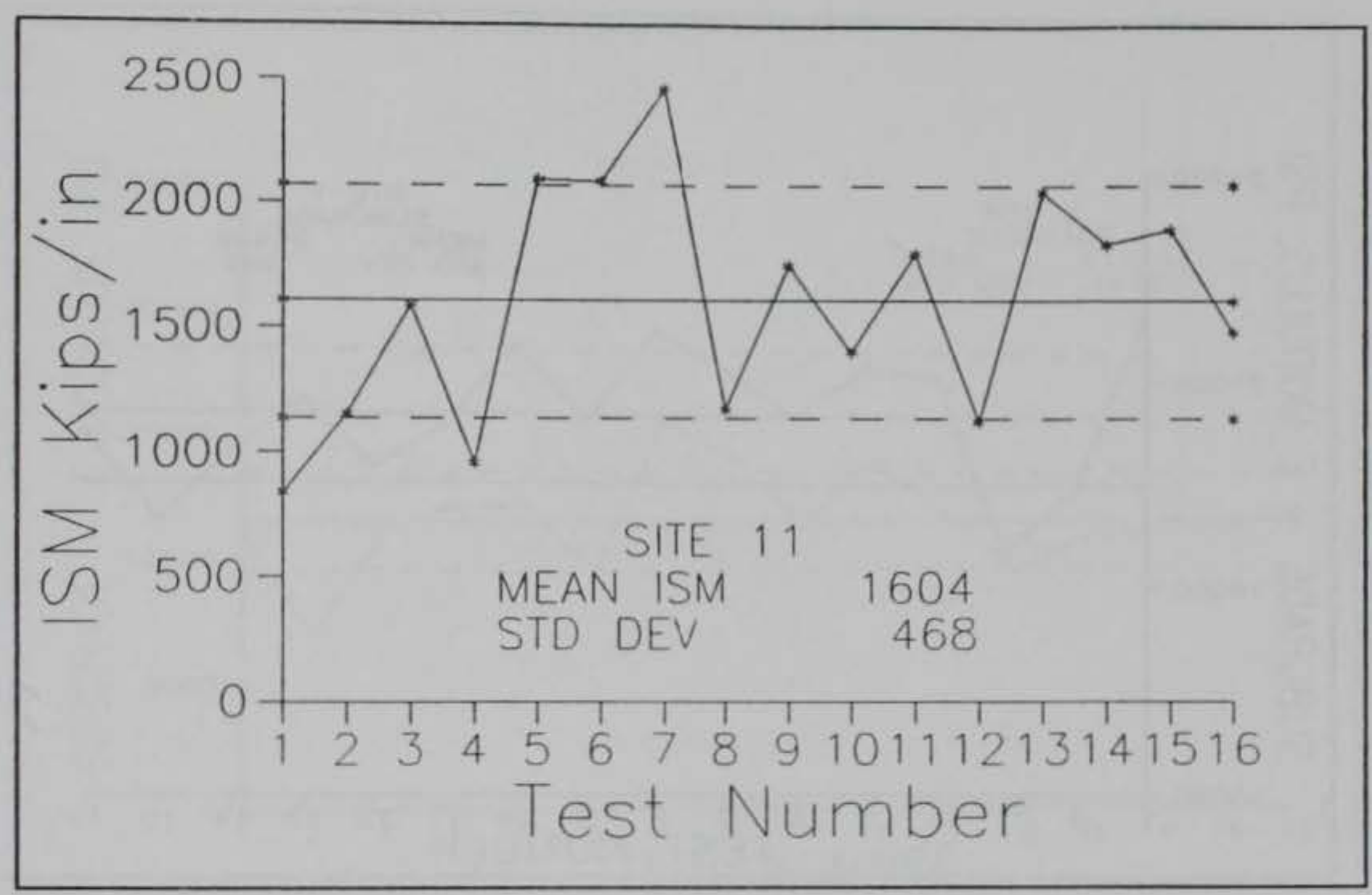

Figure 15. Site 11, ISM vs Test Number

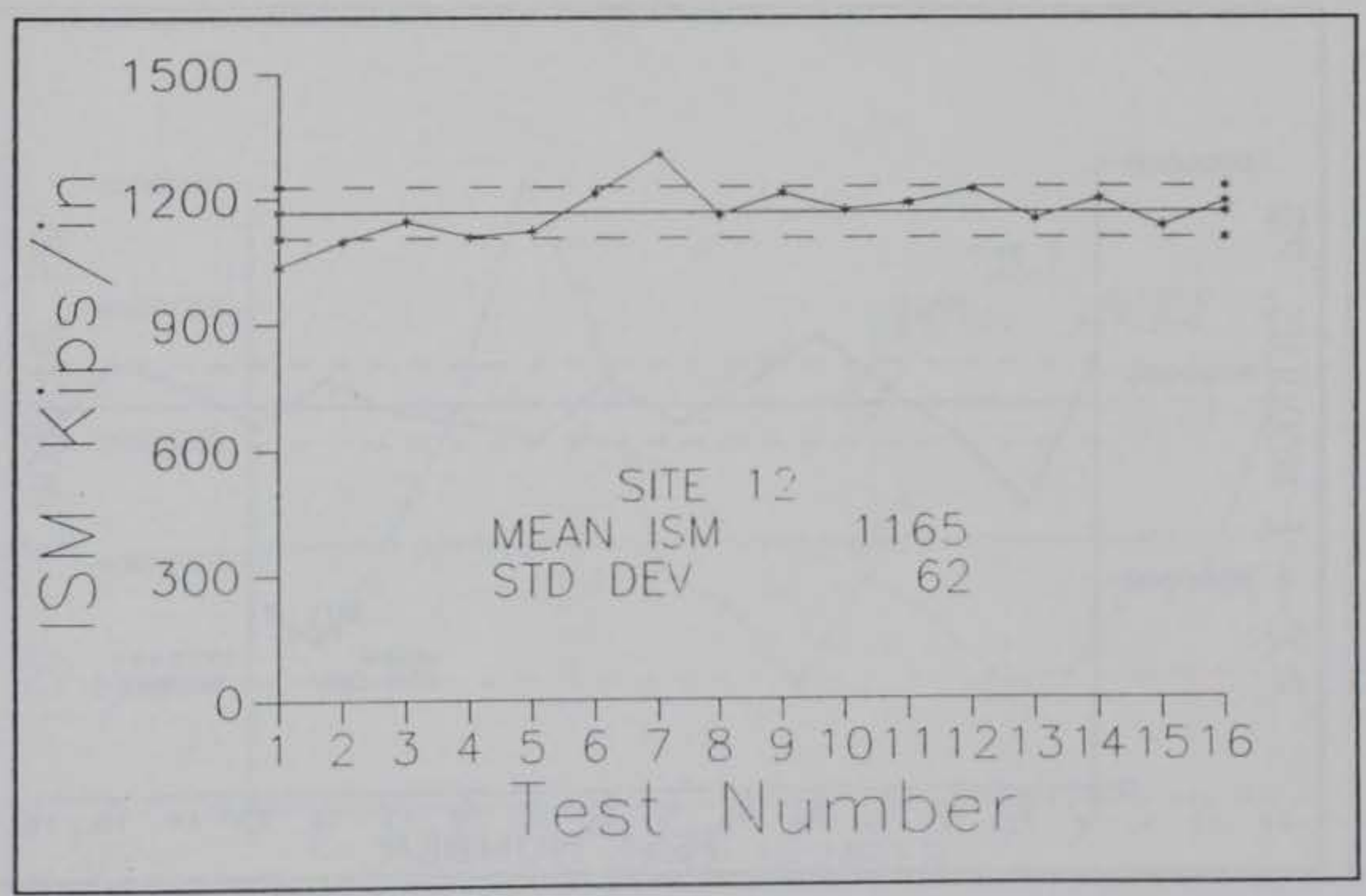

Figure 16. Site 12, ISM vs Test Number 


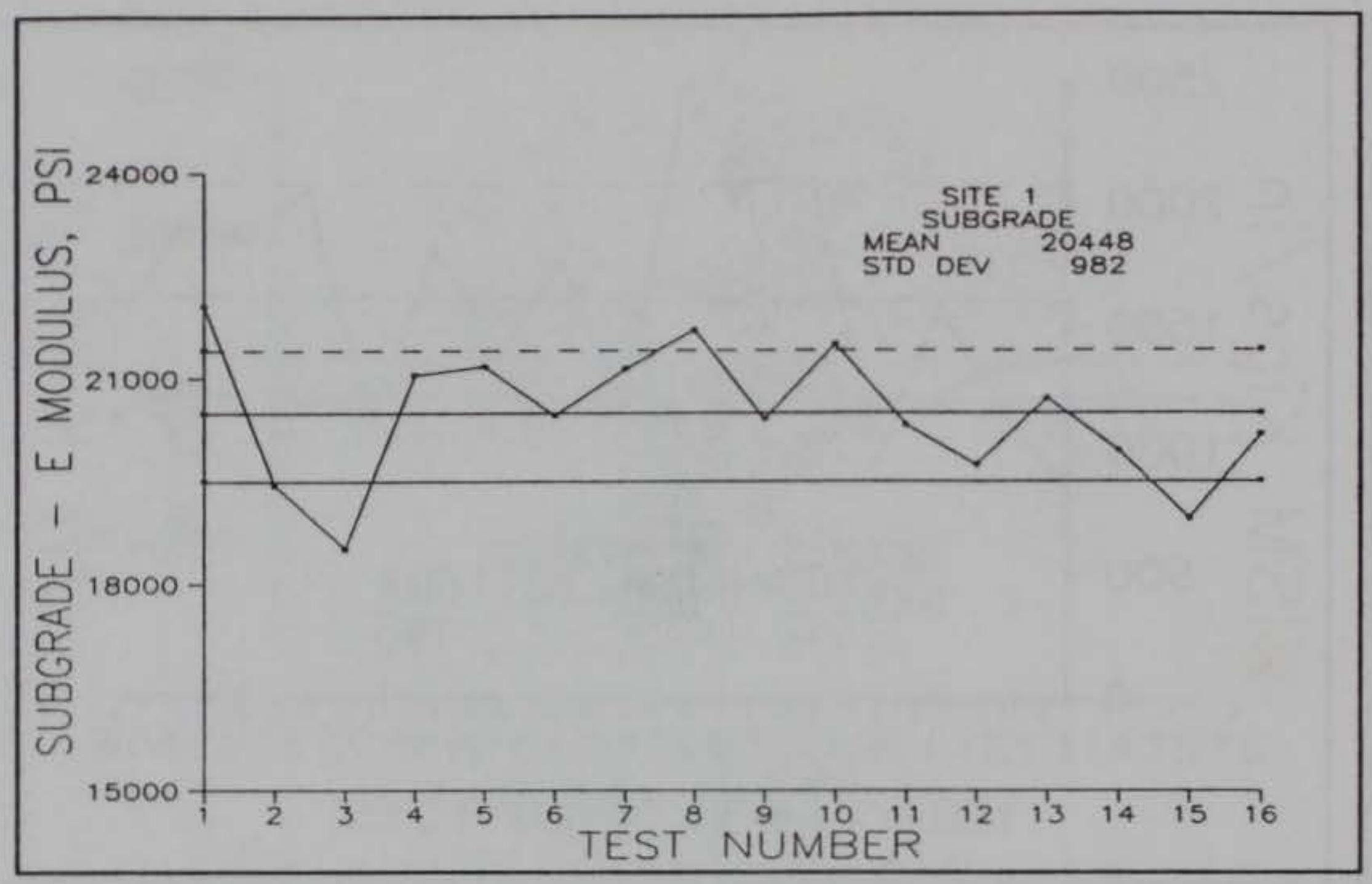

Figure 17. Site 1, Subgrade Modulus vs Test Number

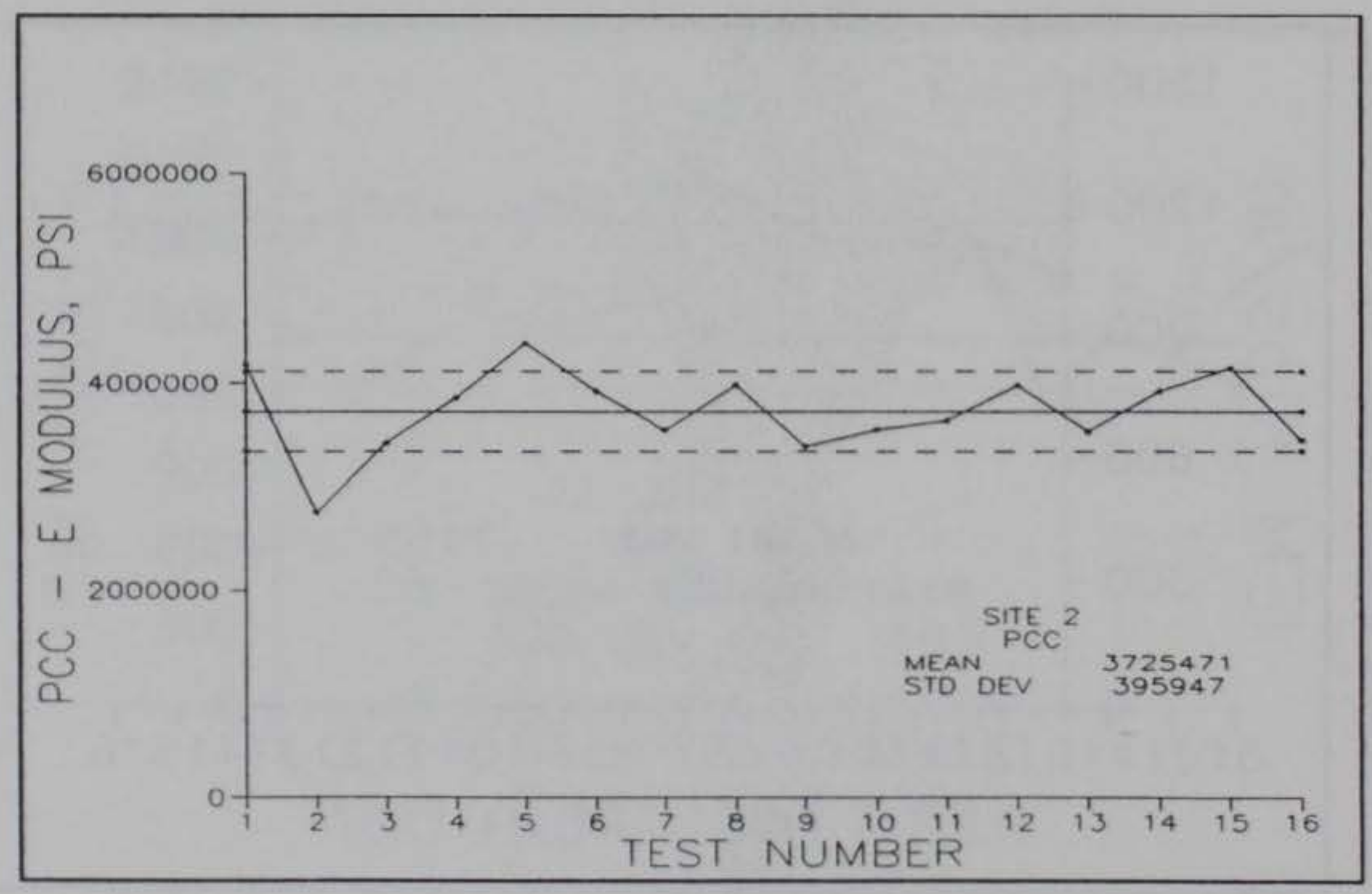

Figure 18. Site 2, PCC Modulus vs Test Number 


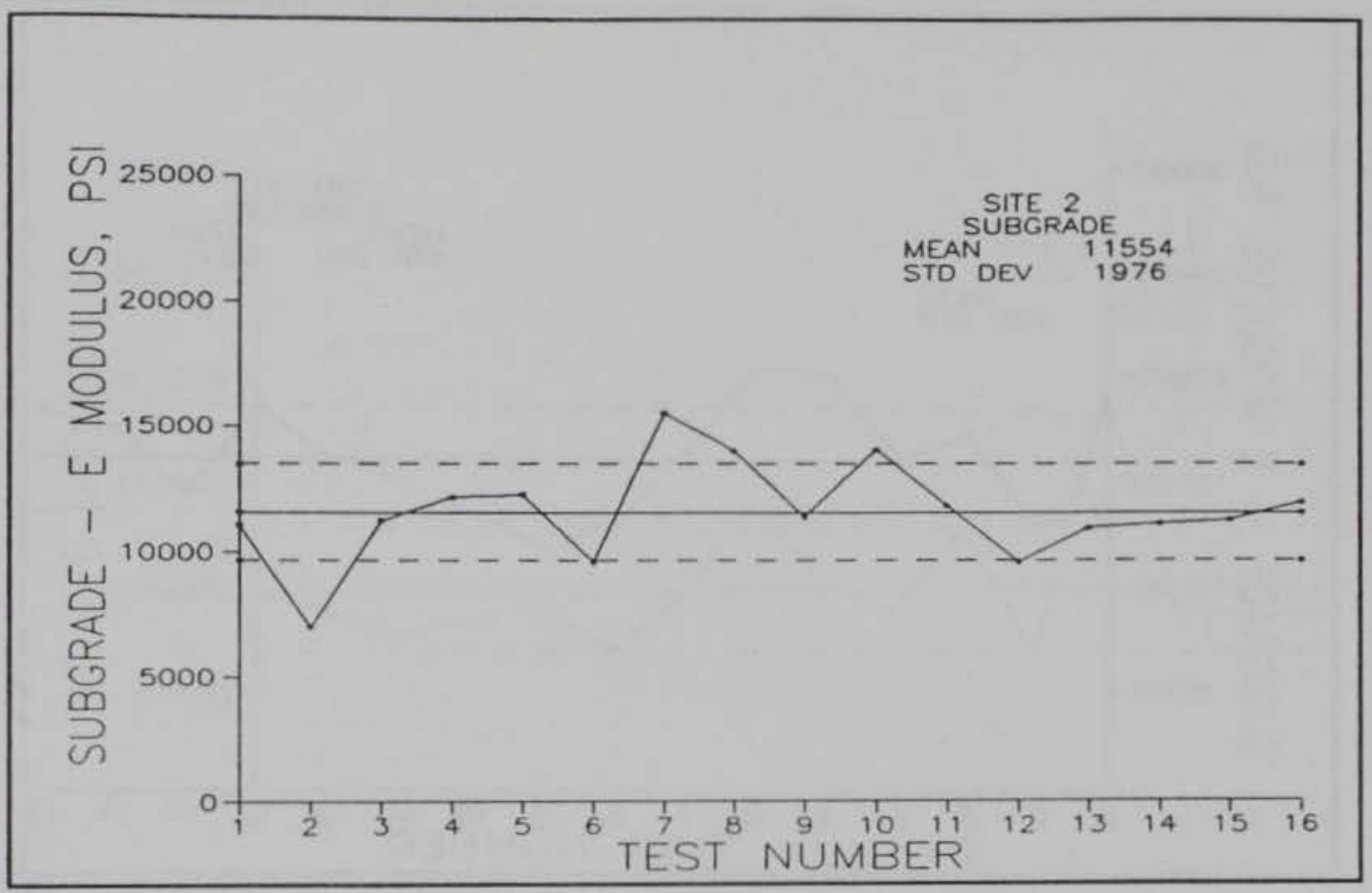

Figure 19. Site 2, Subgrade Modulus vs Test Number

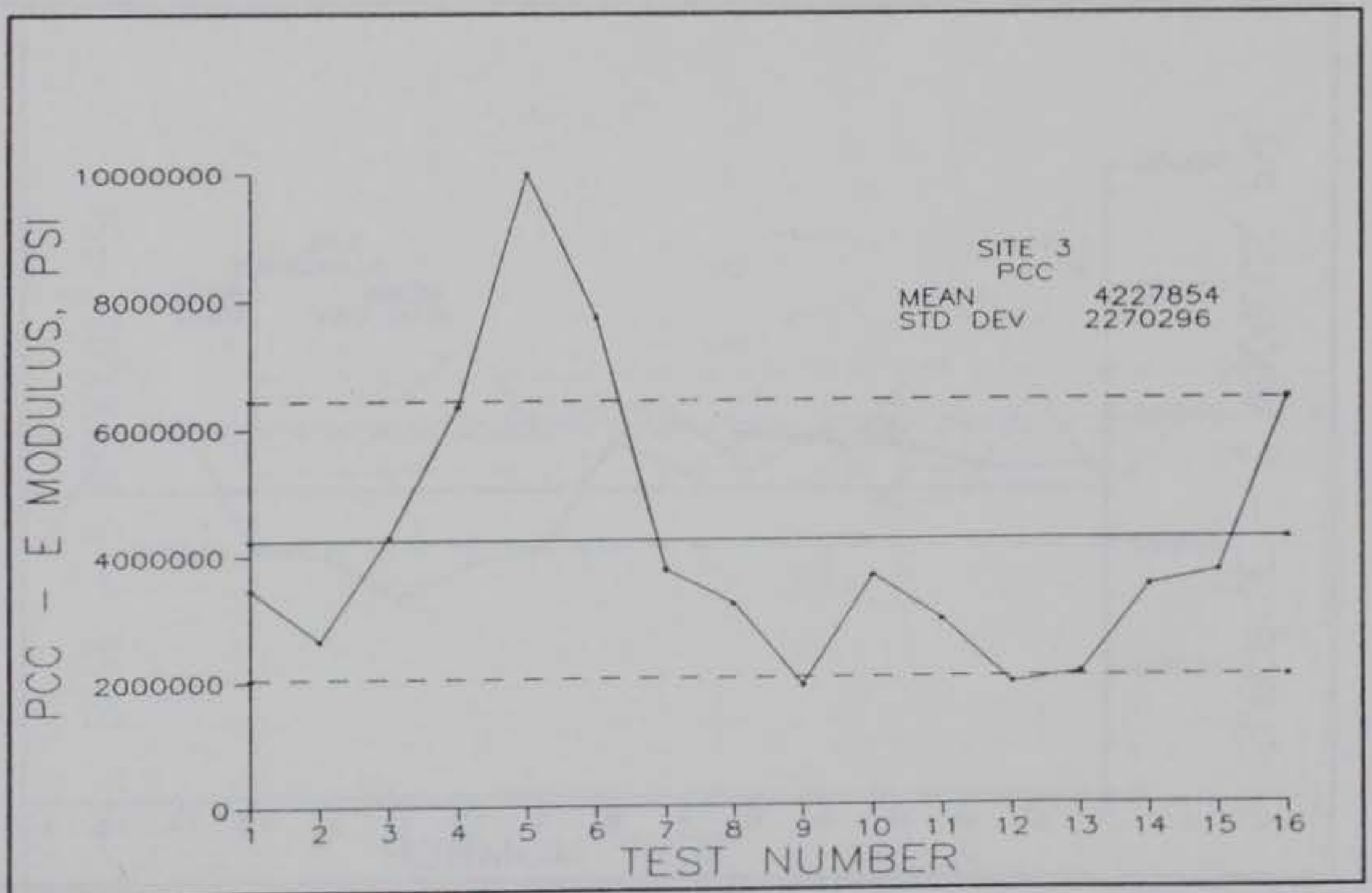

Figure 20. Site 3, PCC Modulus vs Test Number 


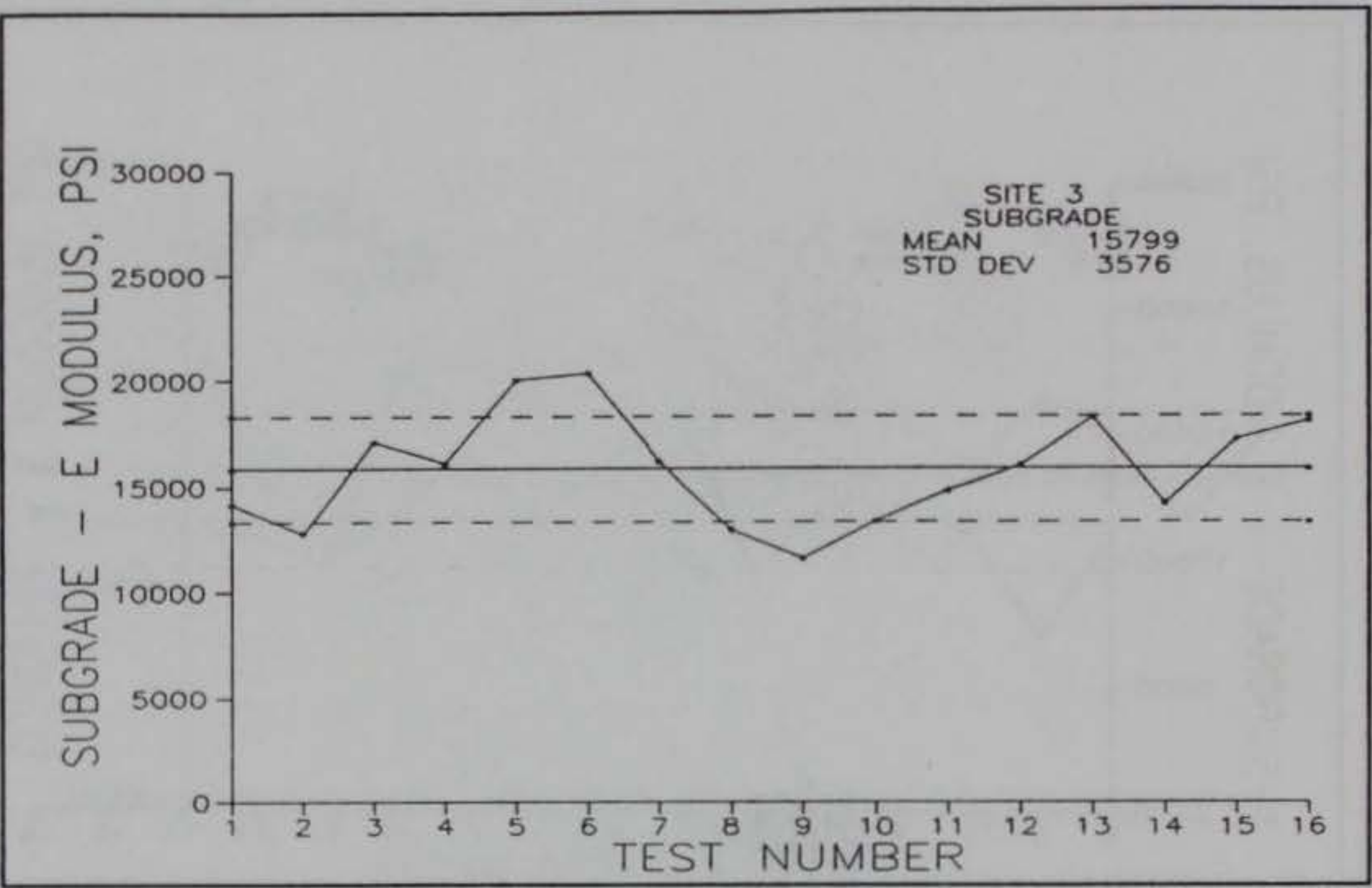

Figure 21. Site 3, Subgrade Modulus vs Test Number

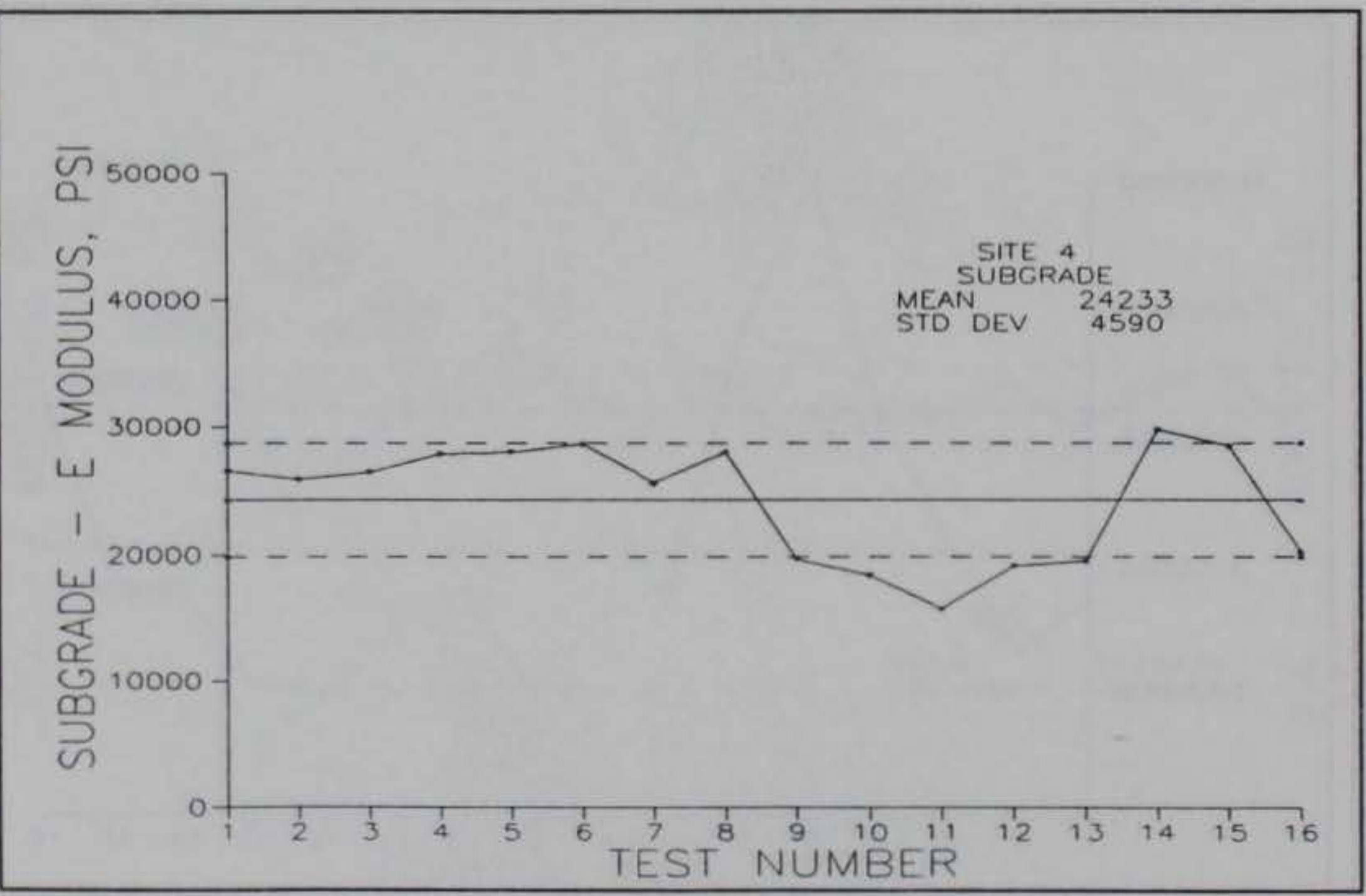

Figure 22. Site 4, Subgrade Modulus vs Test Number 


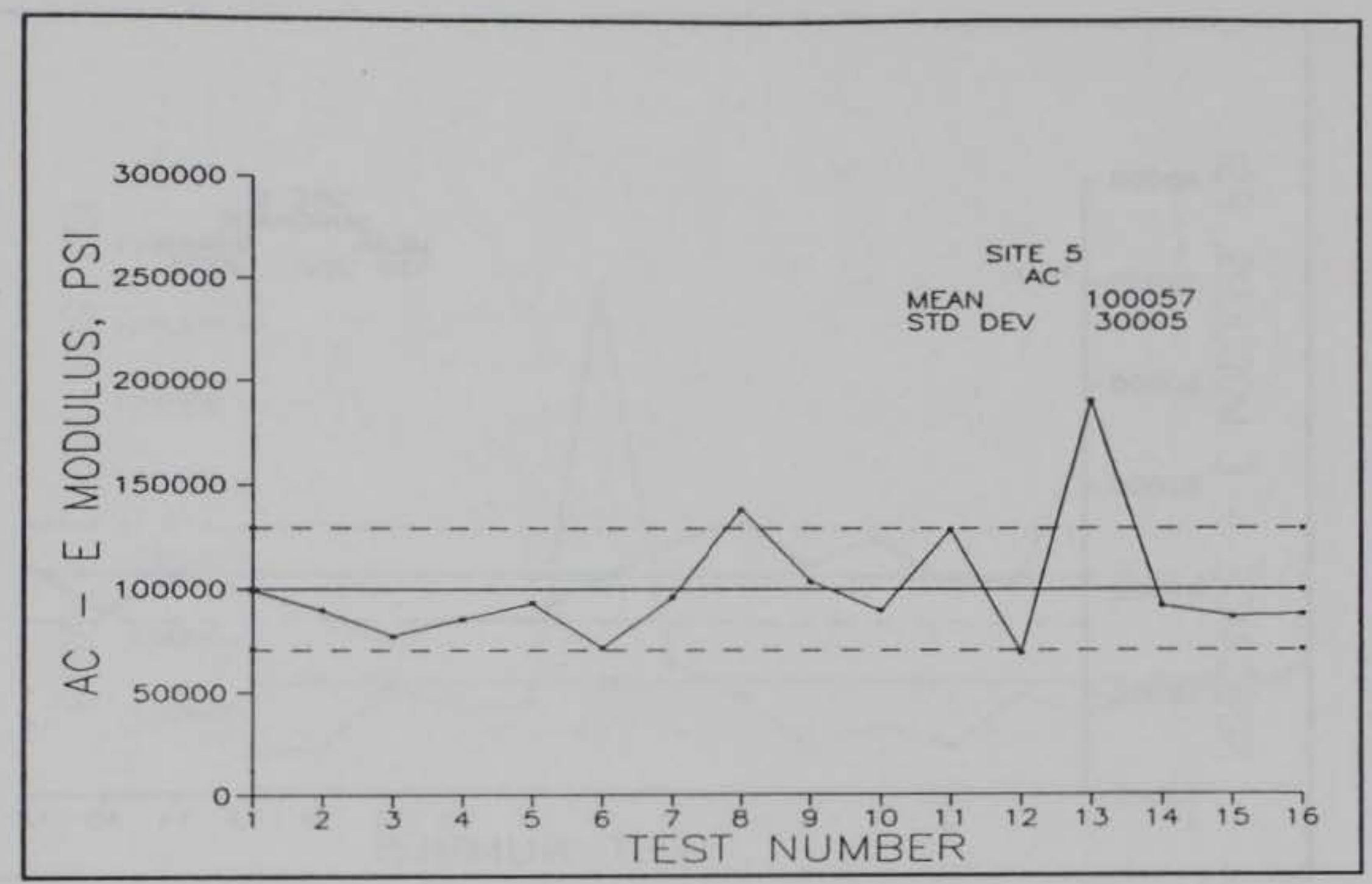

Figure 23. Site 5, AC Modulus vs Test Number

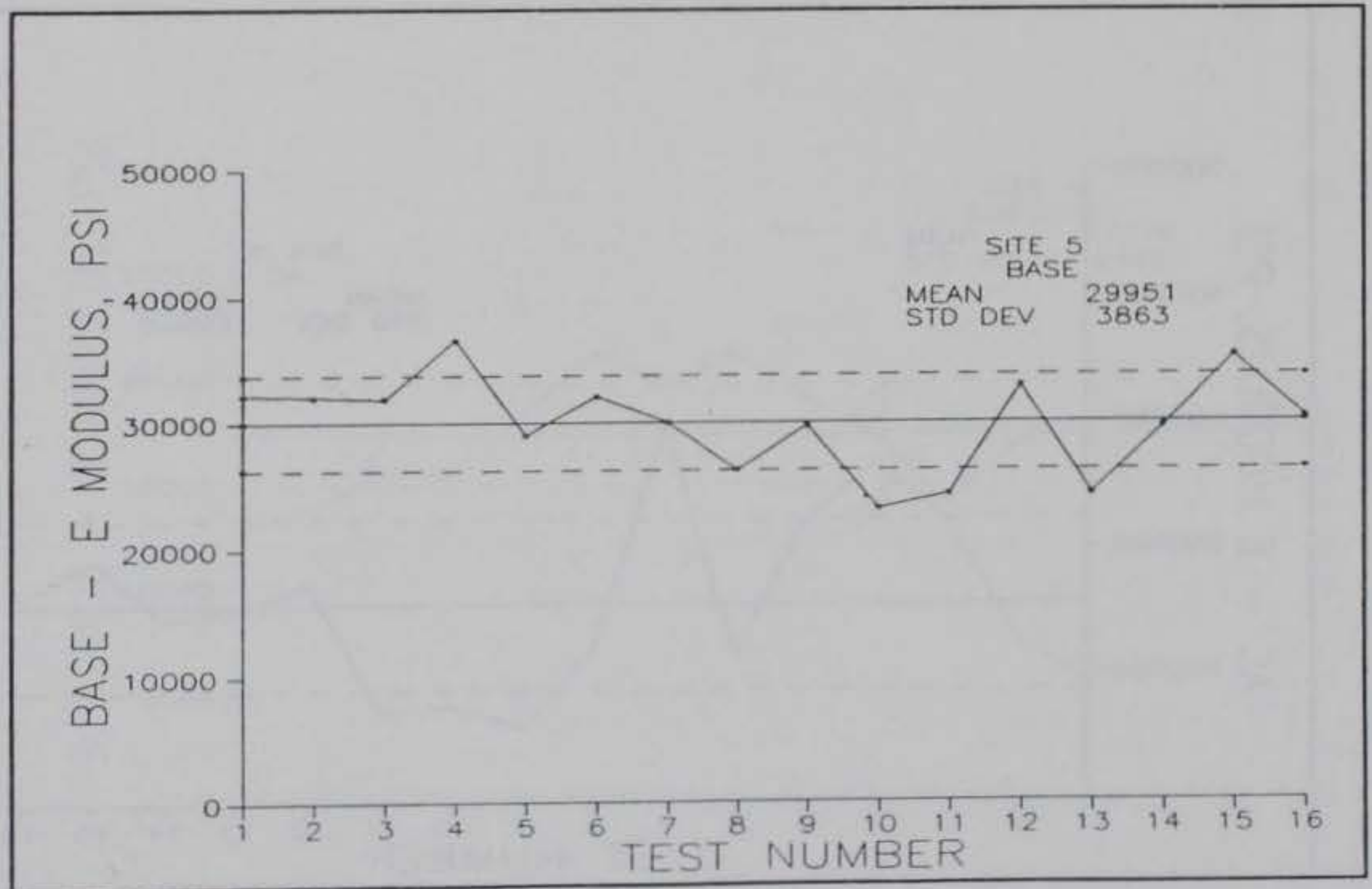

Figure 24. Site 5, Base Modulus vs Test Number 


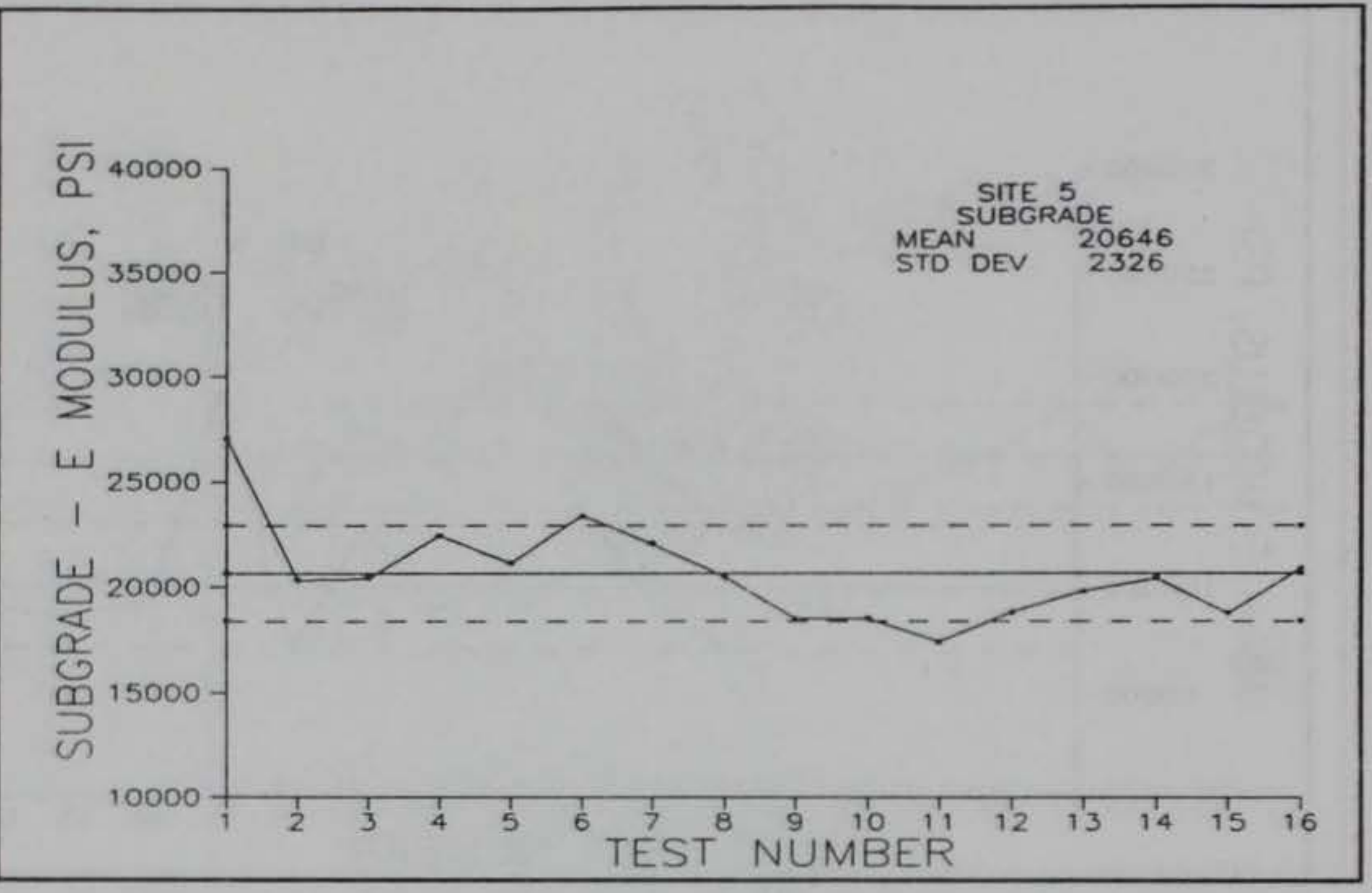

Figure 25. Site 5, Subgrade Modulus vs Test Number

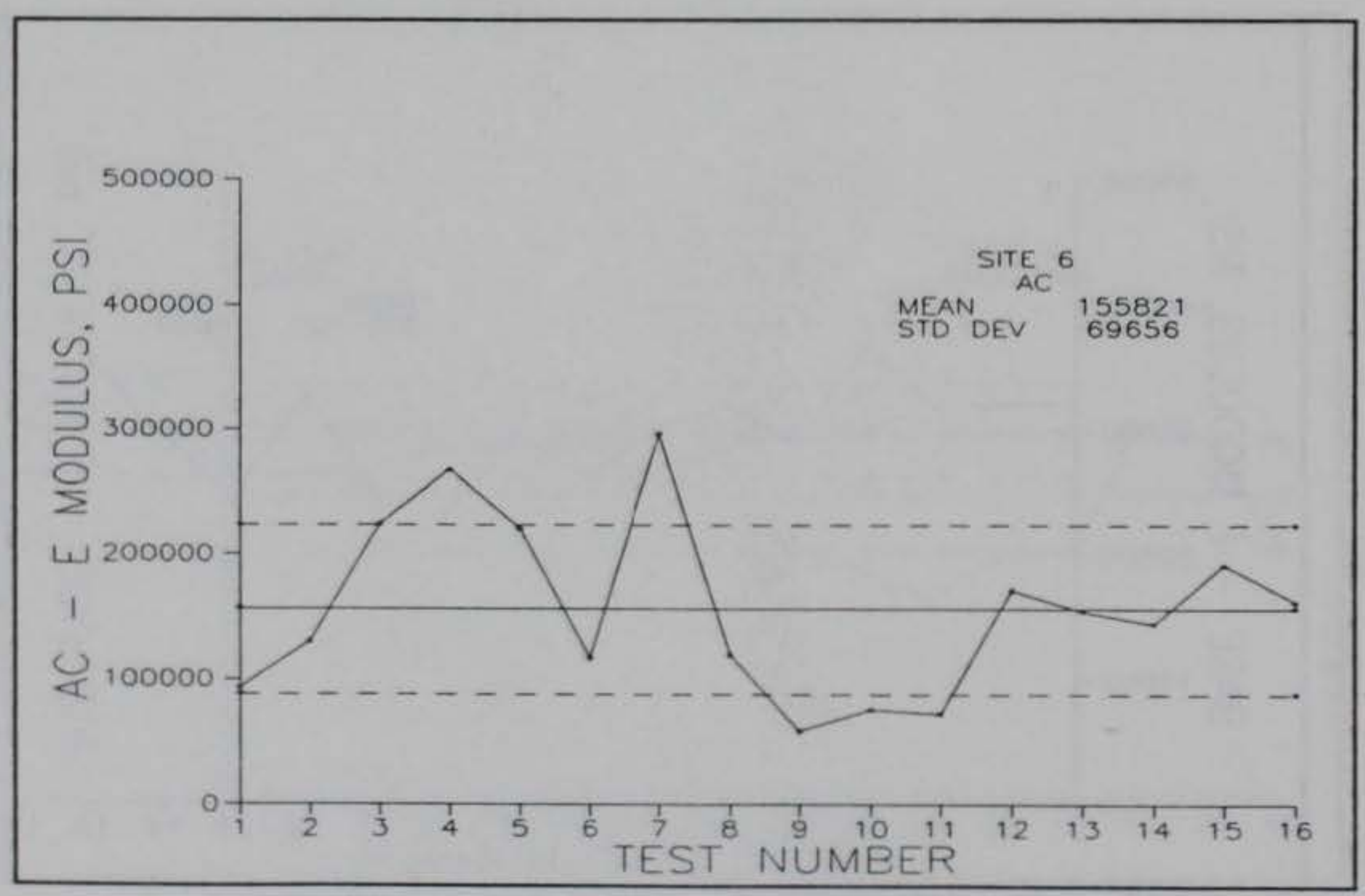

Figure 26. Site 6, AC Modulus vs Test Number 


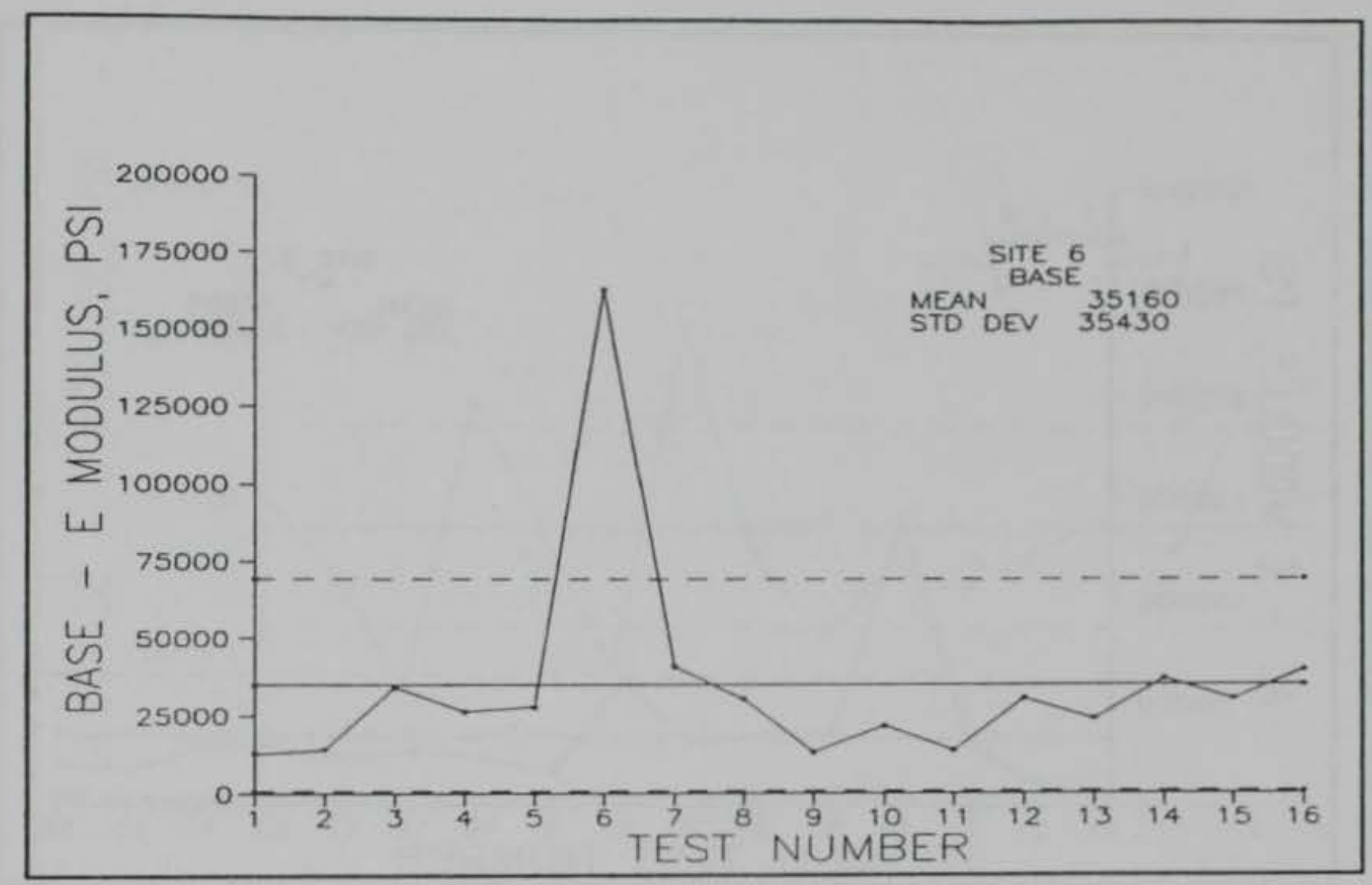

Figure 27. Site 6, Base Modulus vs Test Number

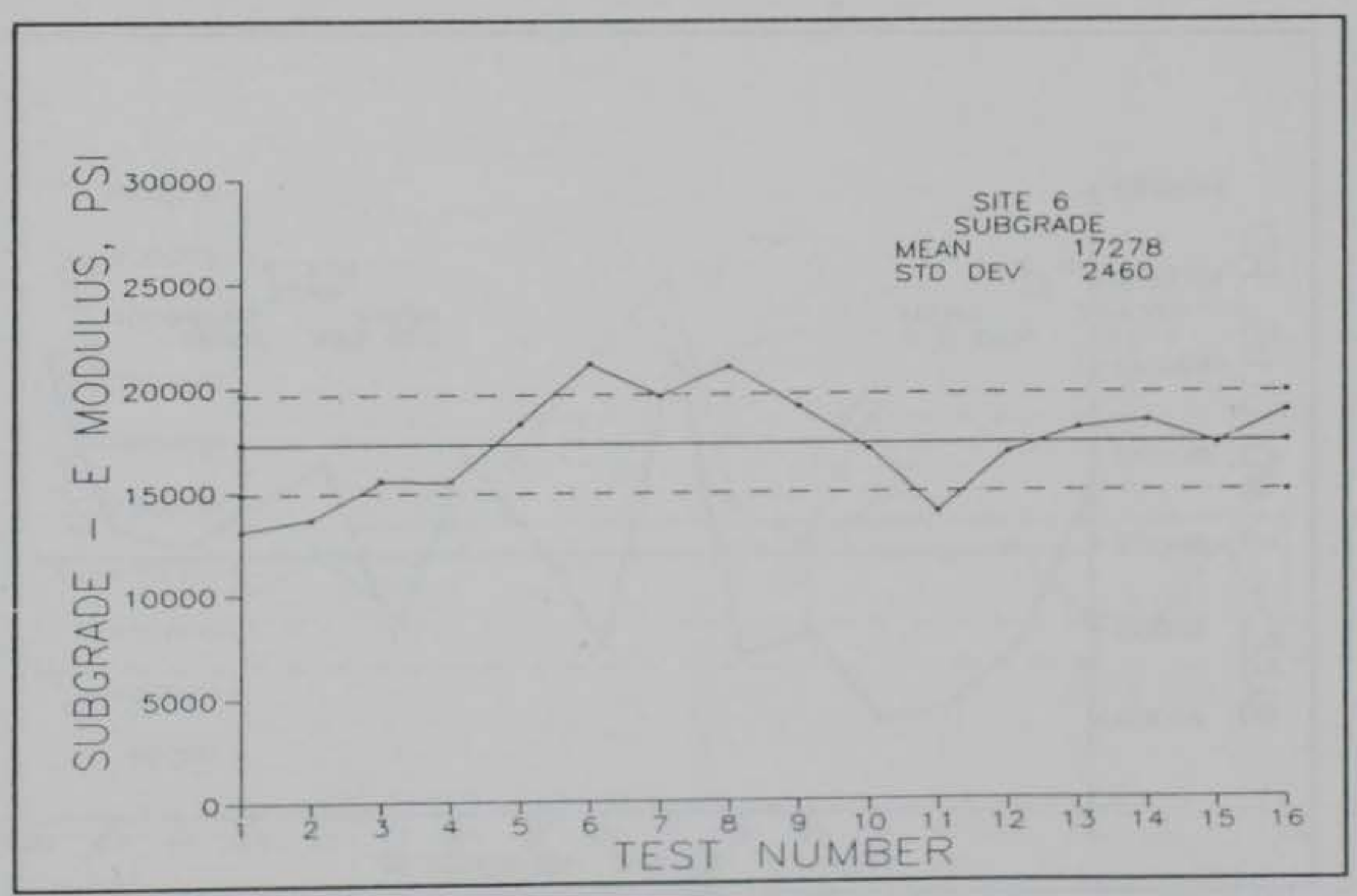

Figure 28. Site 6, Subgrade Modulus vs Test Number 


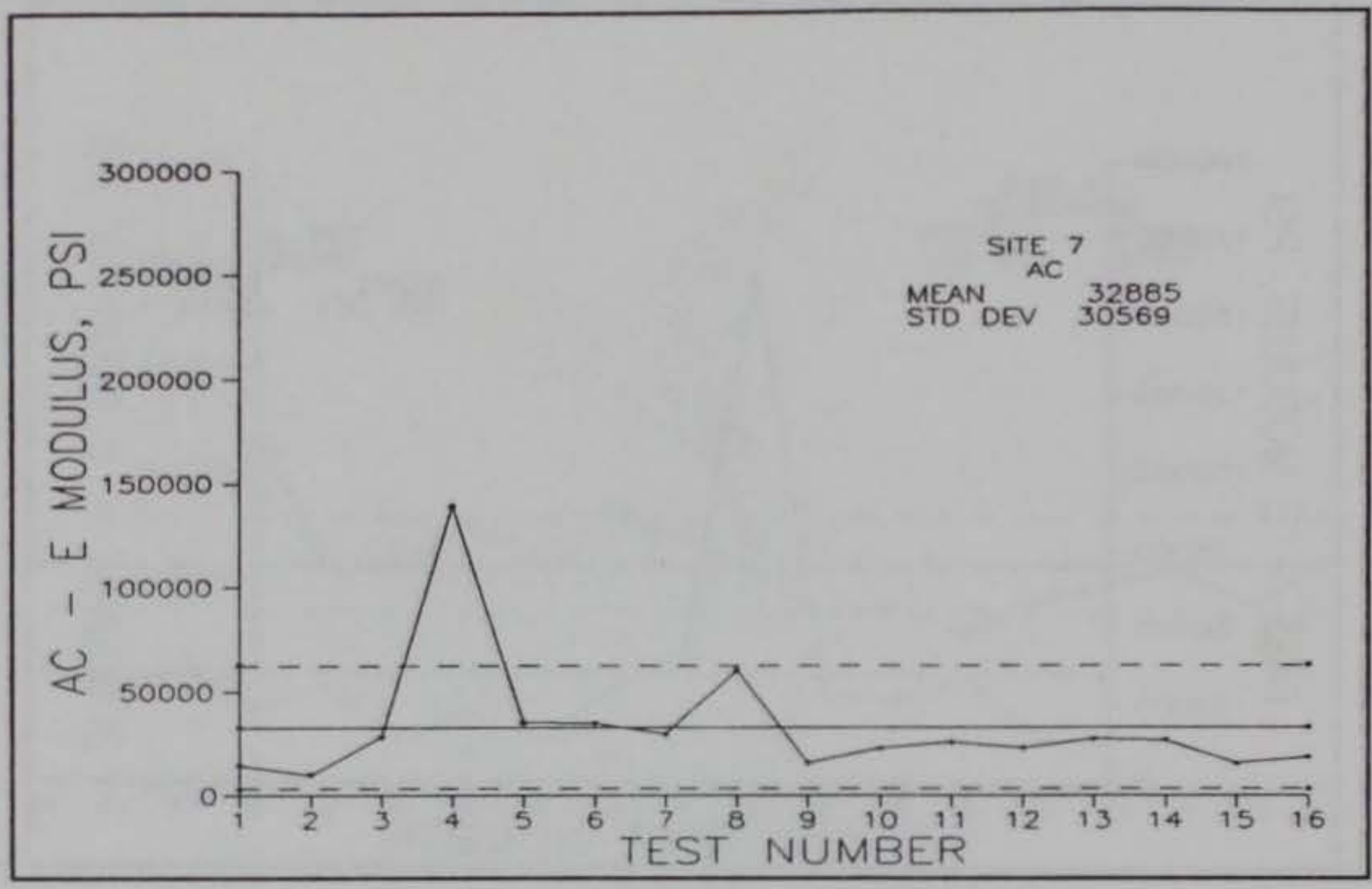

Figure 29. Site 7, AC Modulus vs Test Number

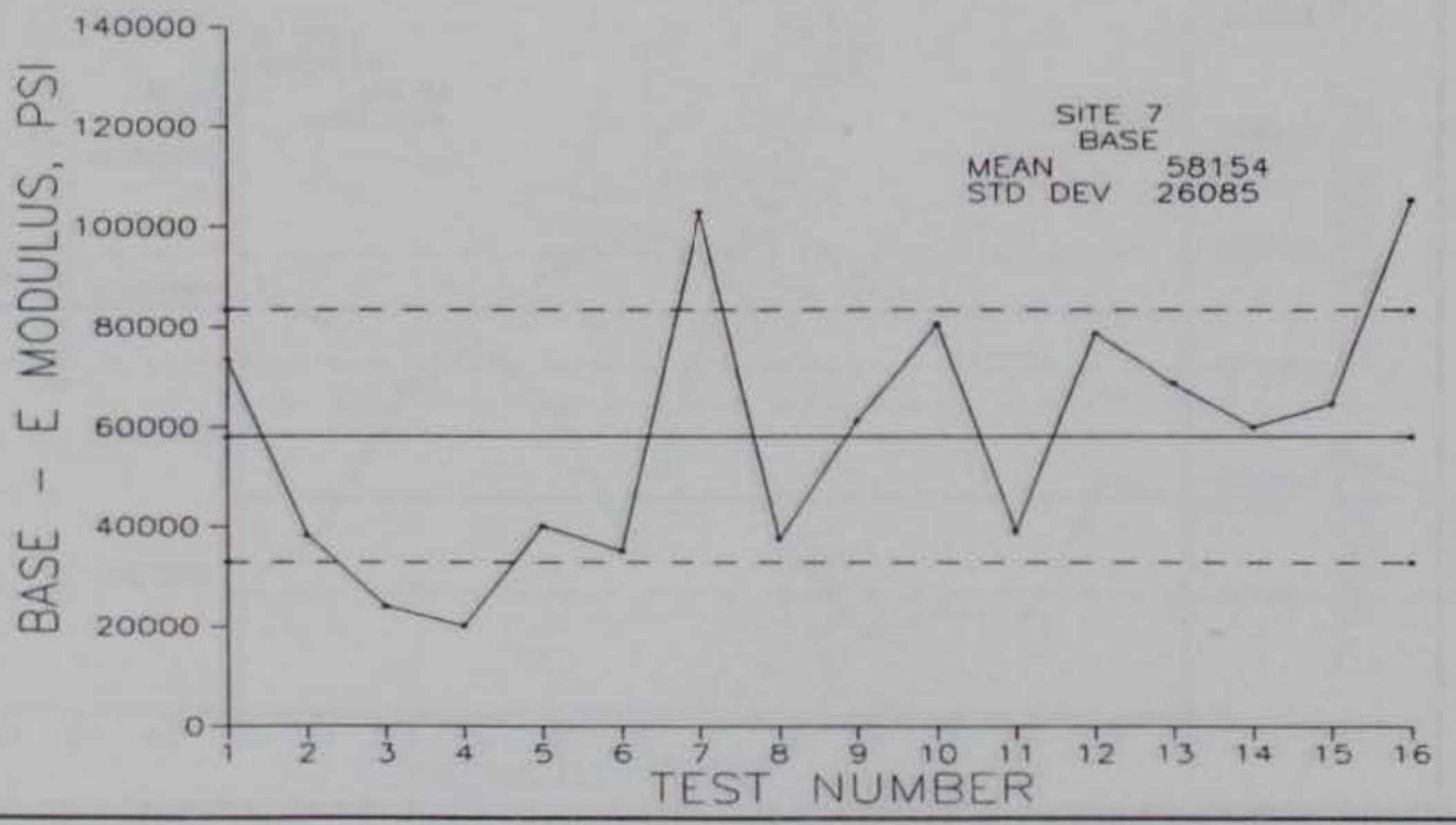

Figure 30. Site 7, Base Modulus vs Test Number 


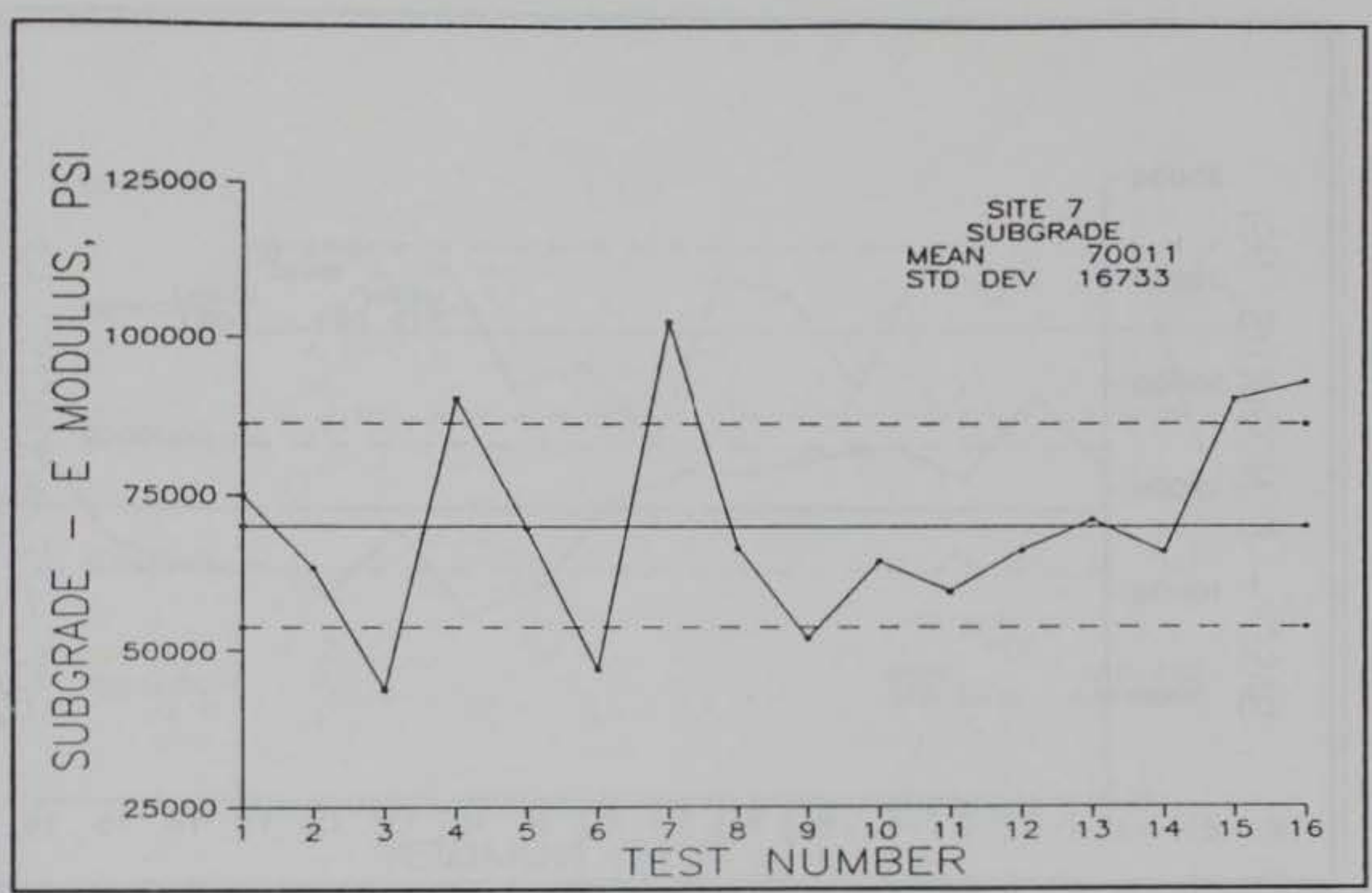

Figure 31. Site 7, Subgrade Modulus vs Test Number

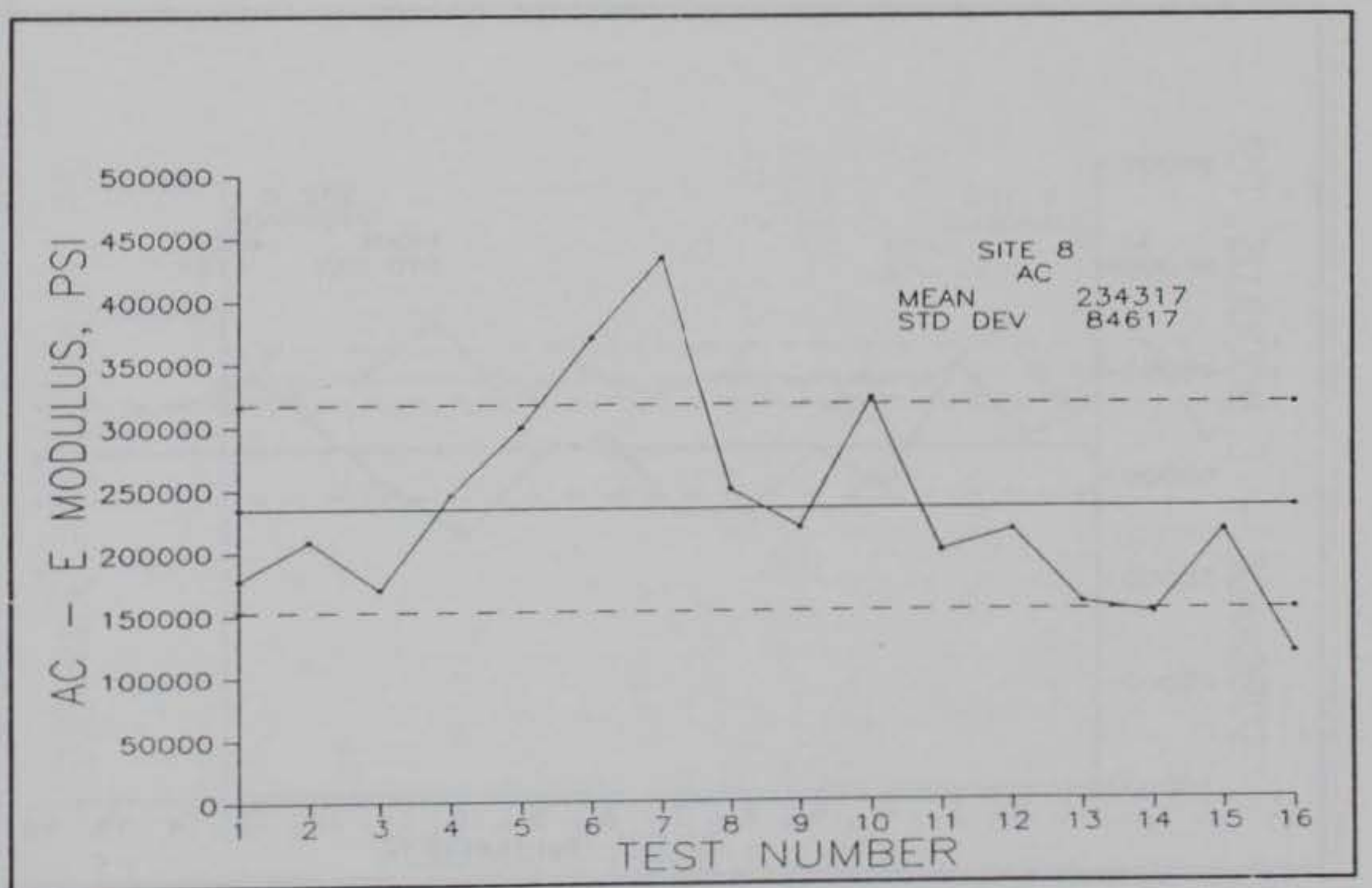

Figure 32. Site $8, \mathrm{AC}$ Modulus vs Test Number 


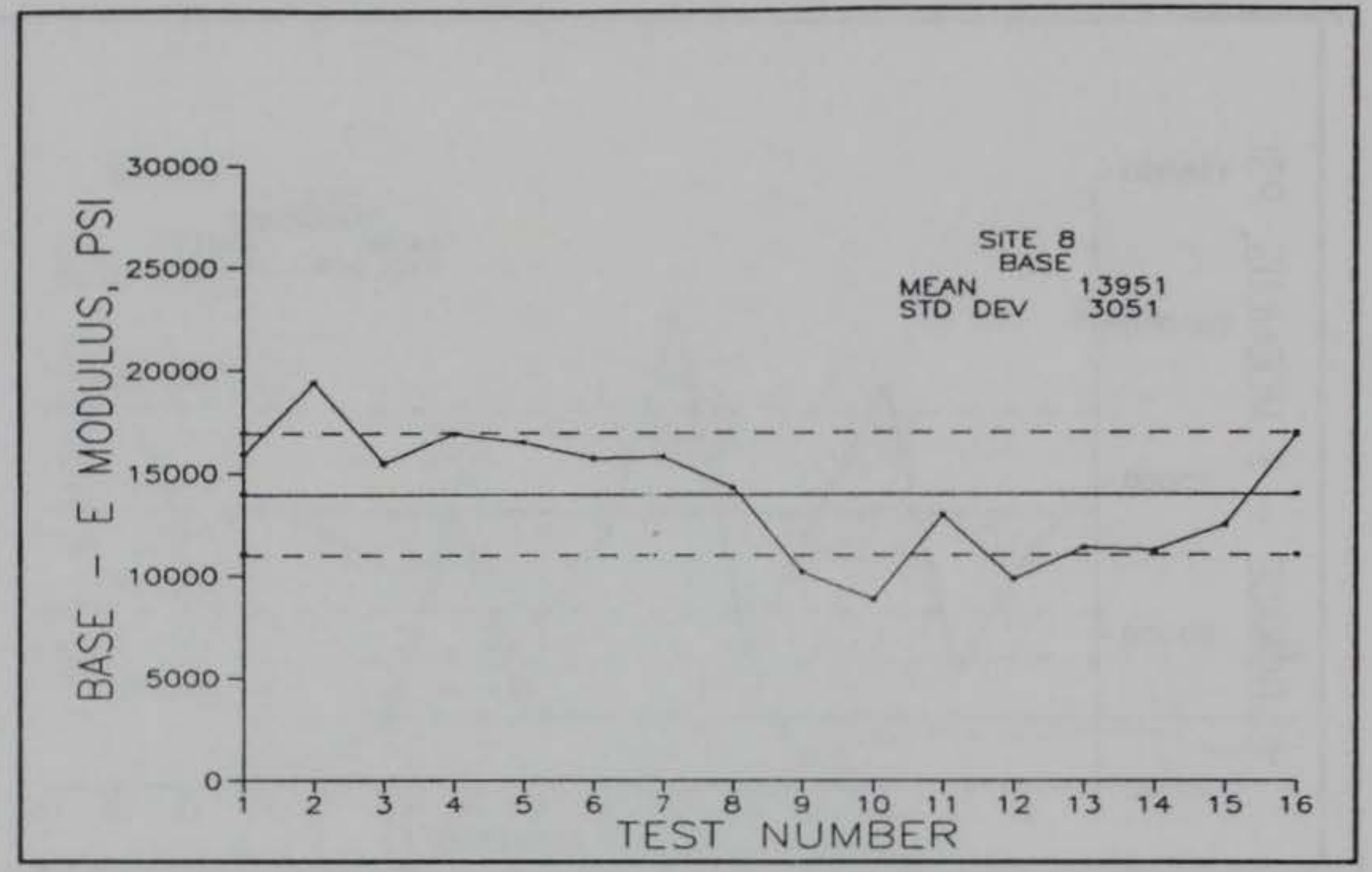

Figure 33. Site 8 , Base Modulus vs Test Number

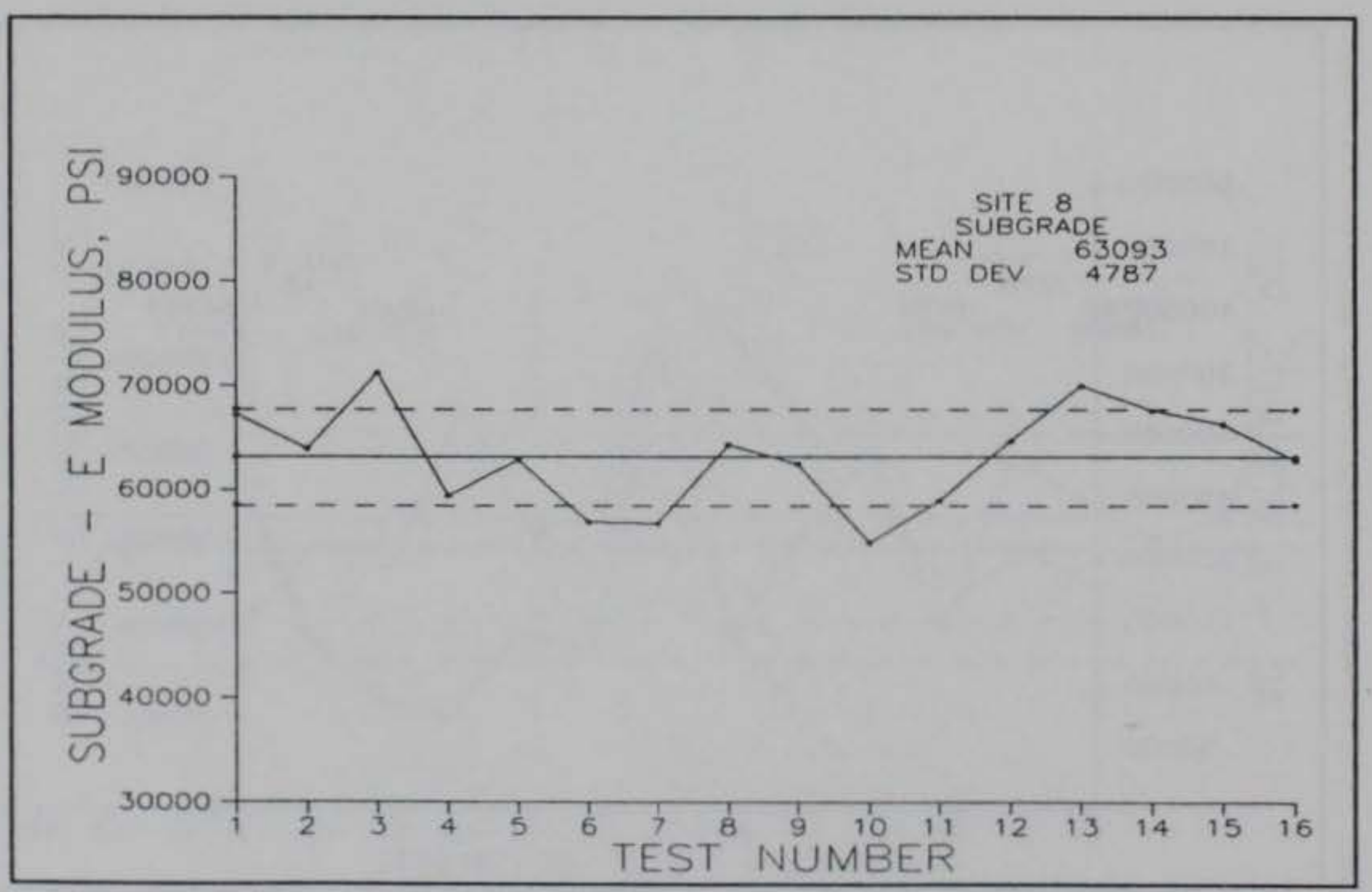

Figure 34. Site 8 , Subgrade Modulus vs Test Number 


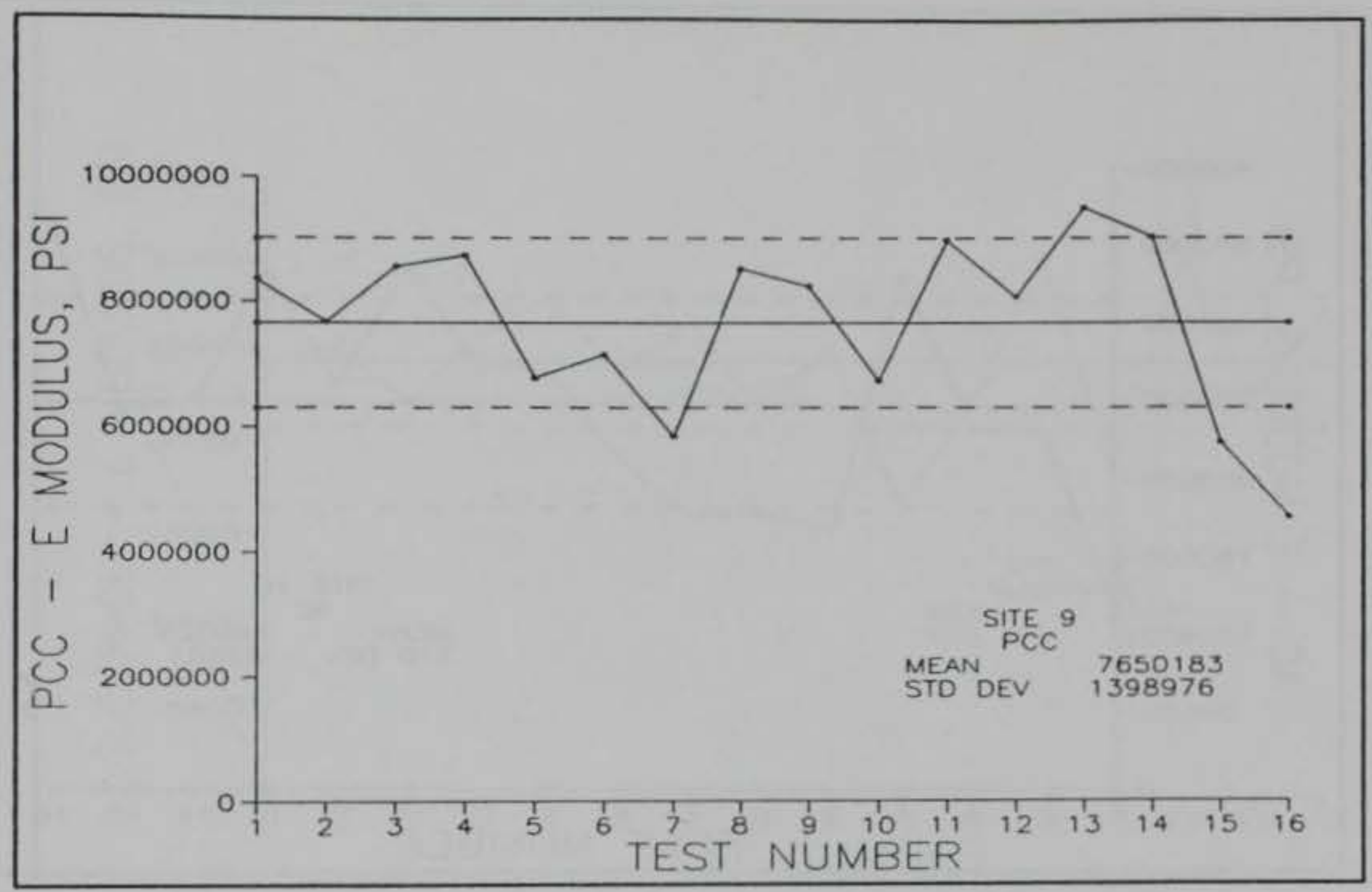

Figure 35. Site 9, PCC Modulus vs Test Number

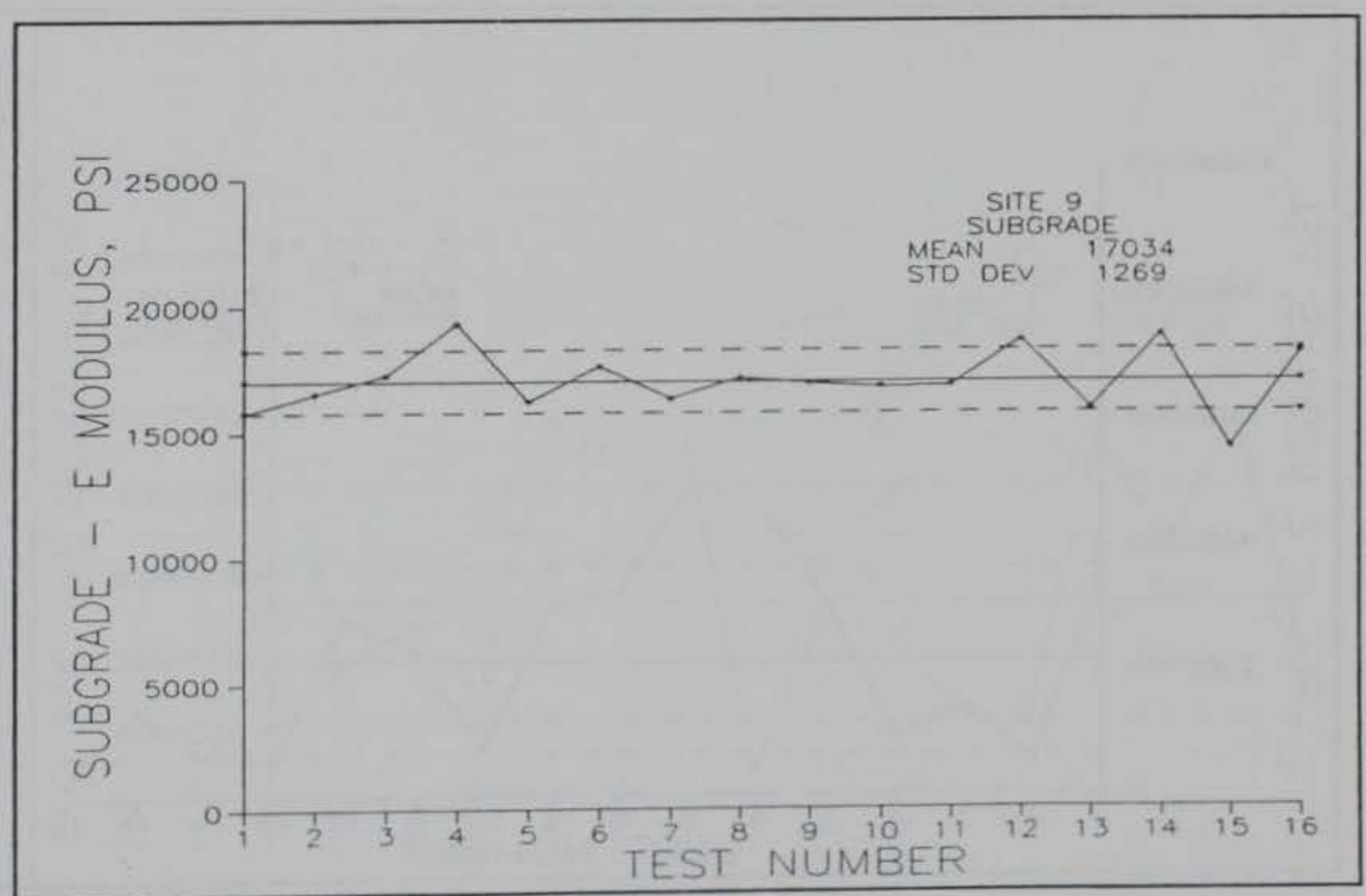

Figure 36. Site 9, Subgrade Modulus vs Test Number 


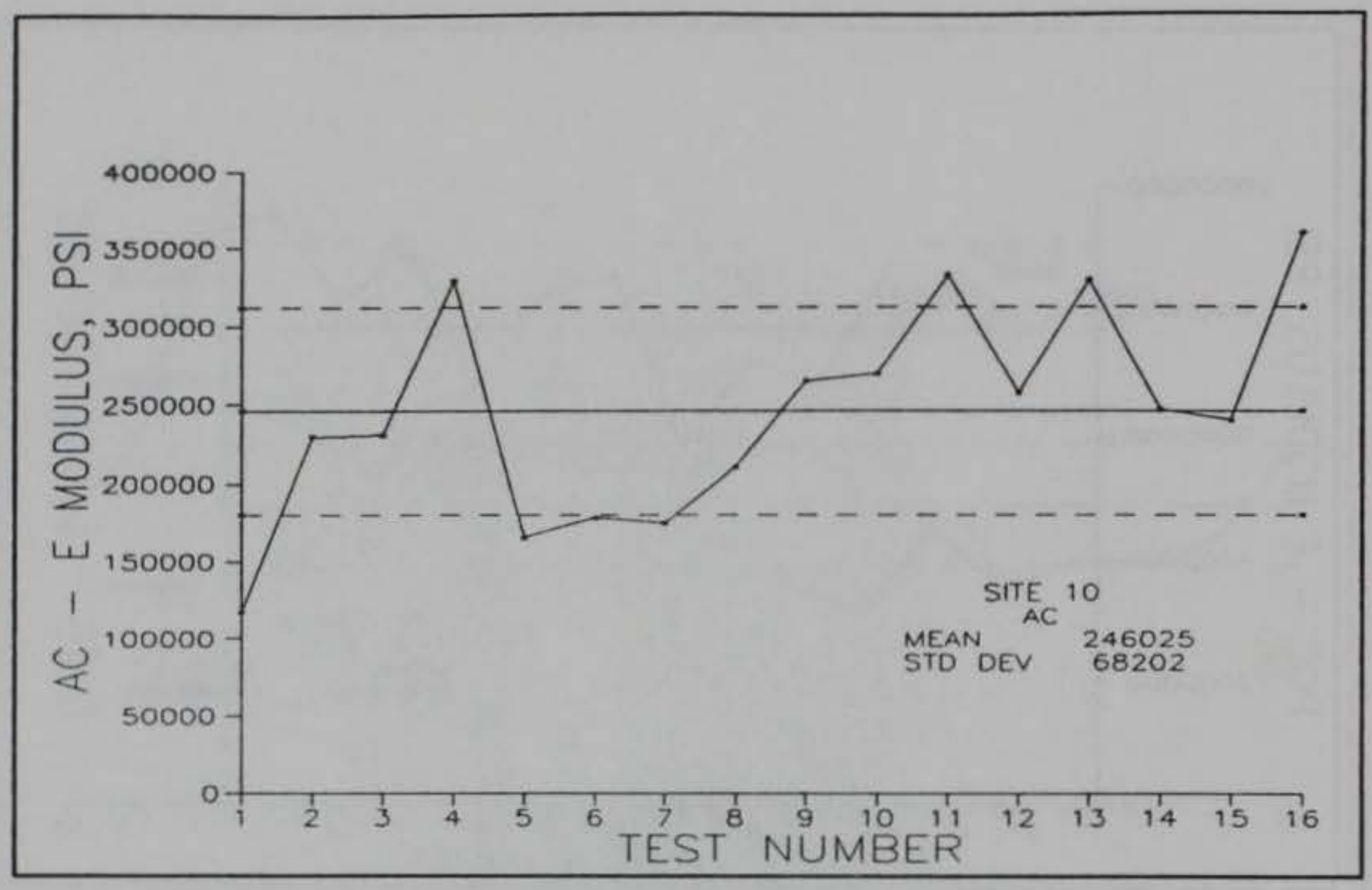

Figure 37. Site 10, AC Modulus vs Test Number

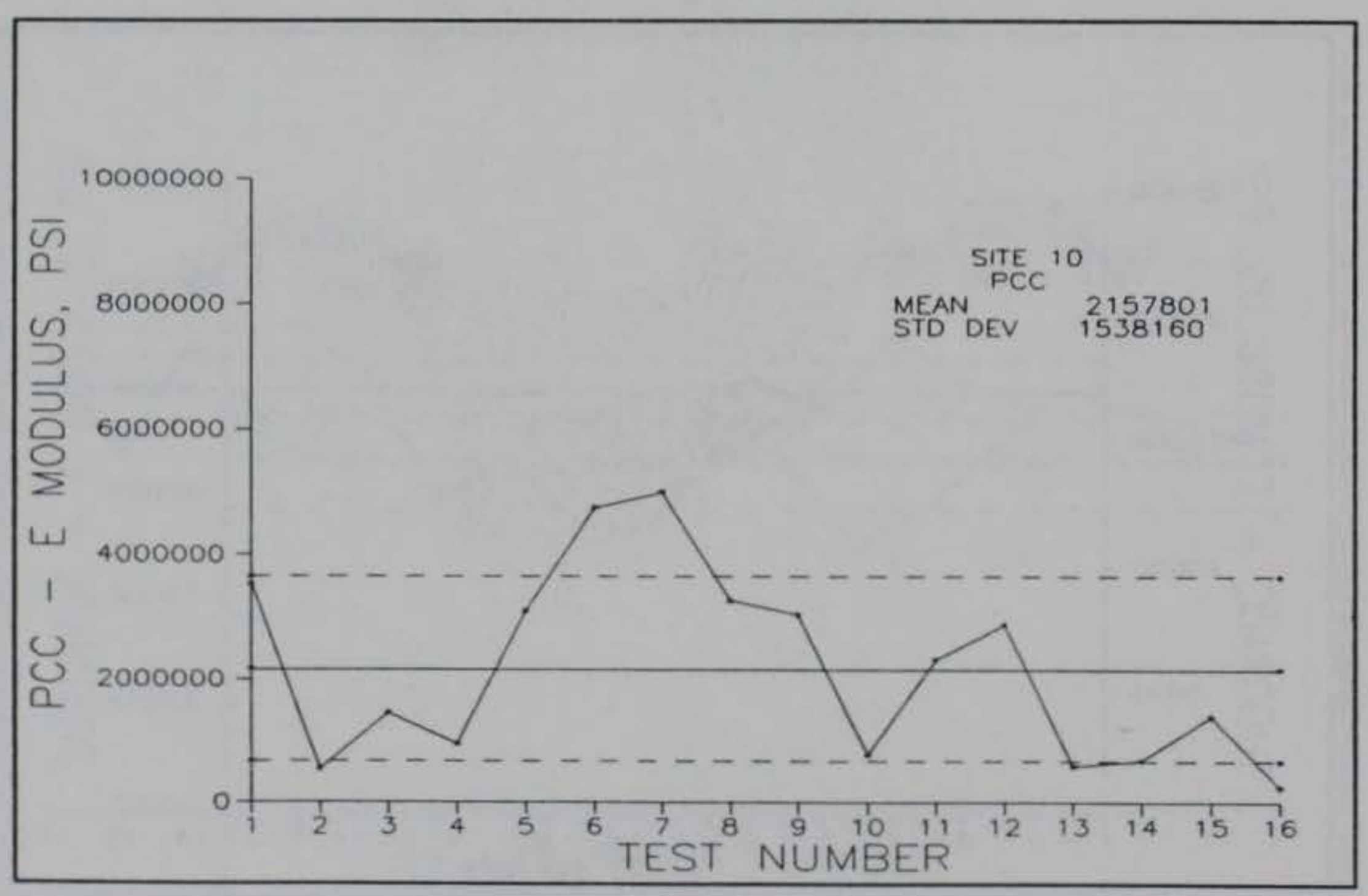

Figure 38. Site 10, PCC Modulus vs Test Number 


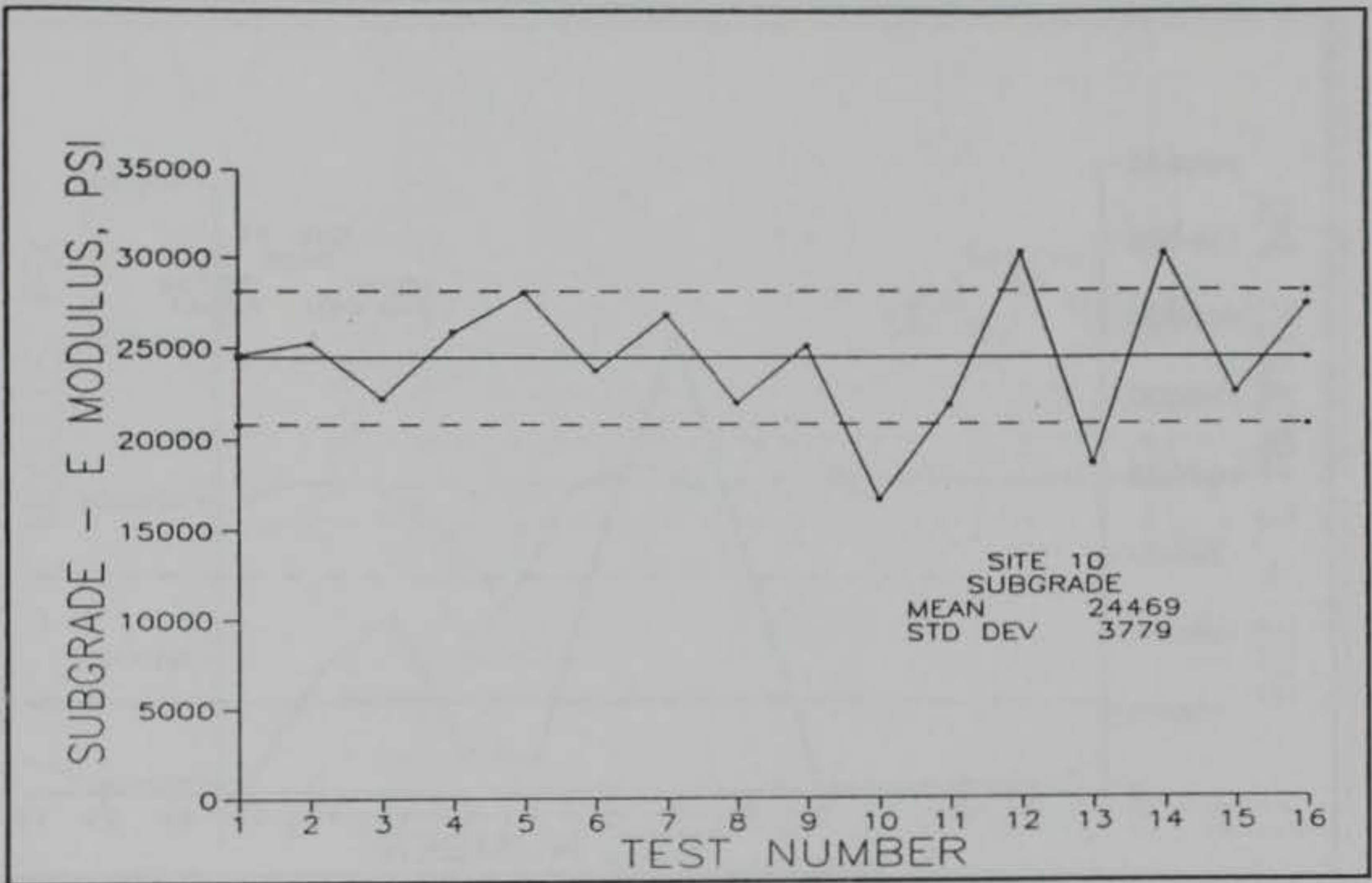

Figure 39. Site 10, Subgrade Modulus vs Test Number

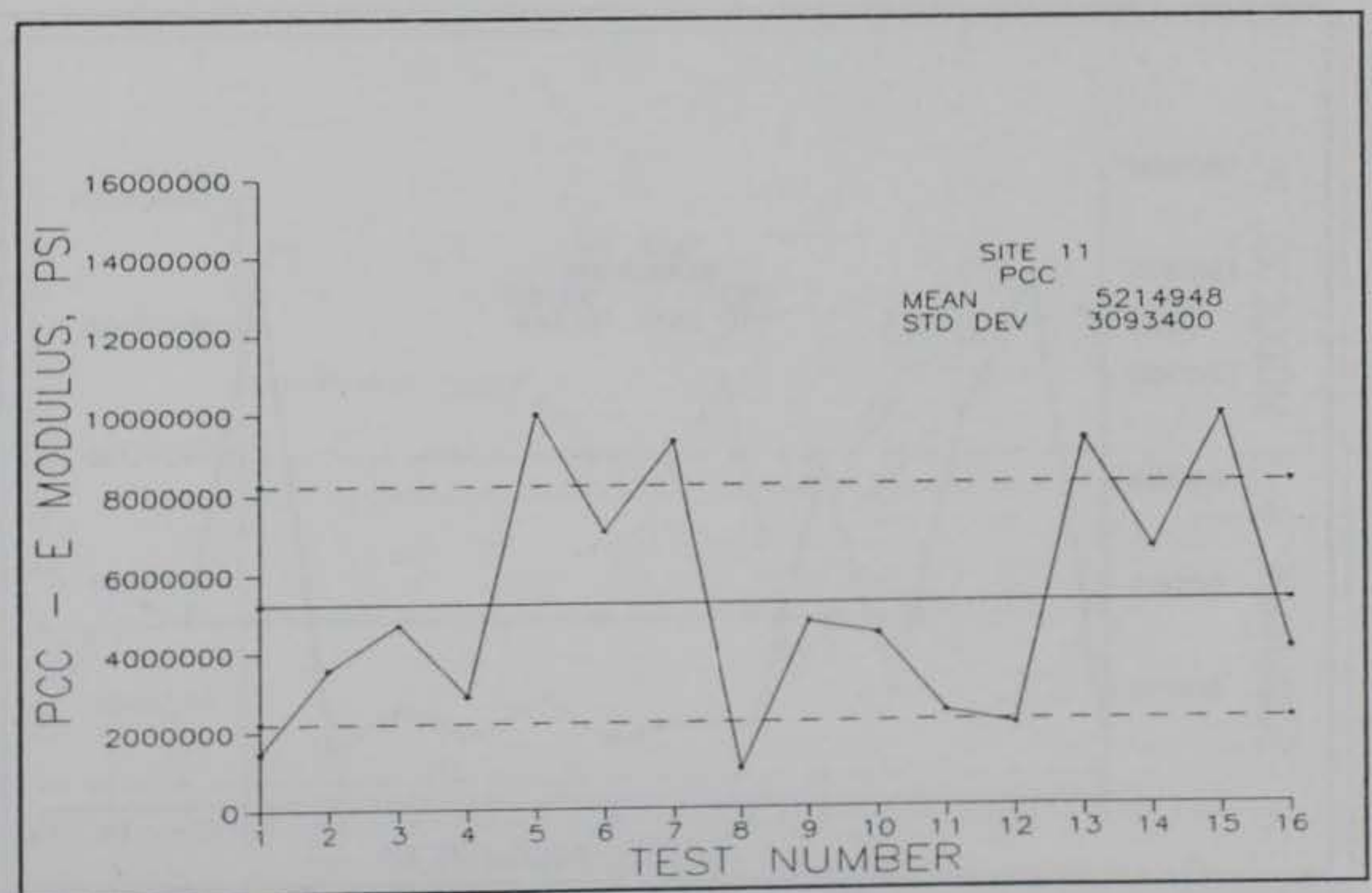

Figure 40. Site 11, PCC Modulus vs Test Number 


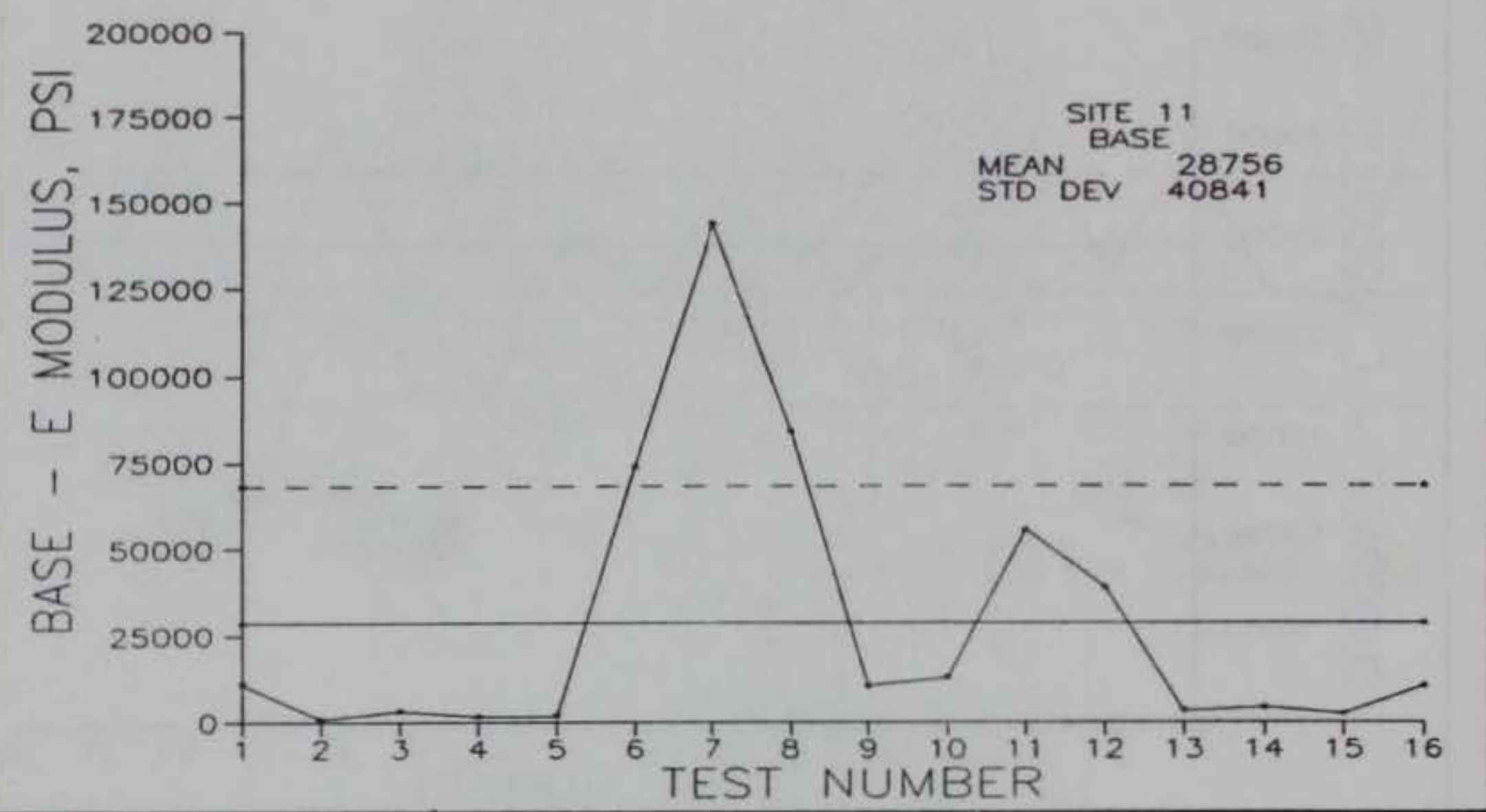

Figure 41. Site 11, Base Modulus vs Test Number

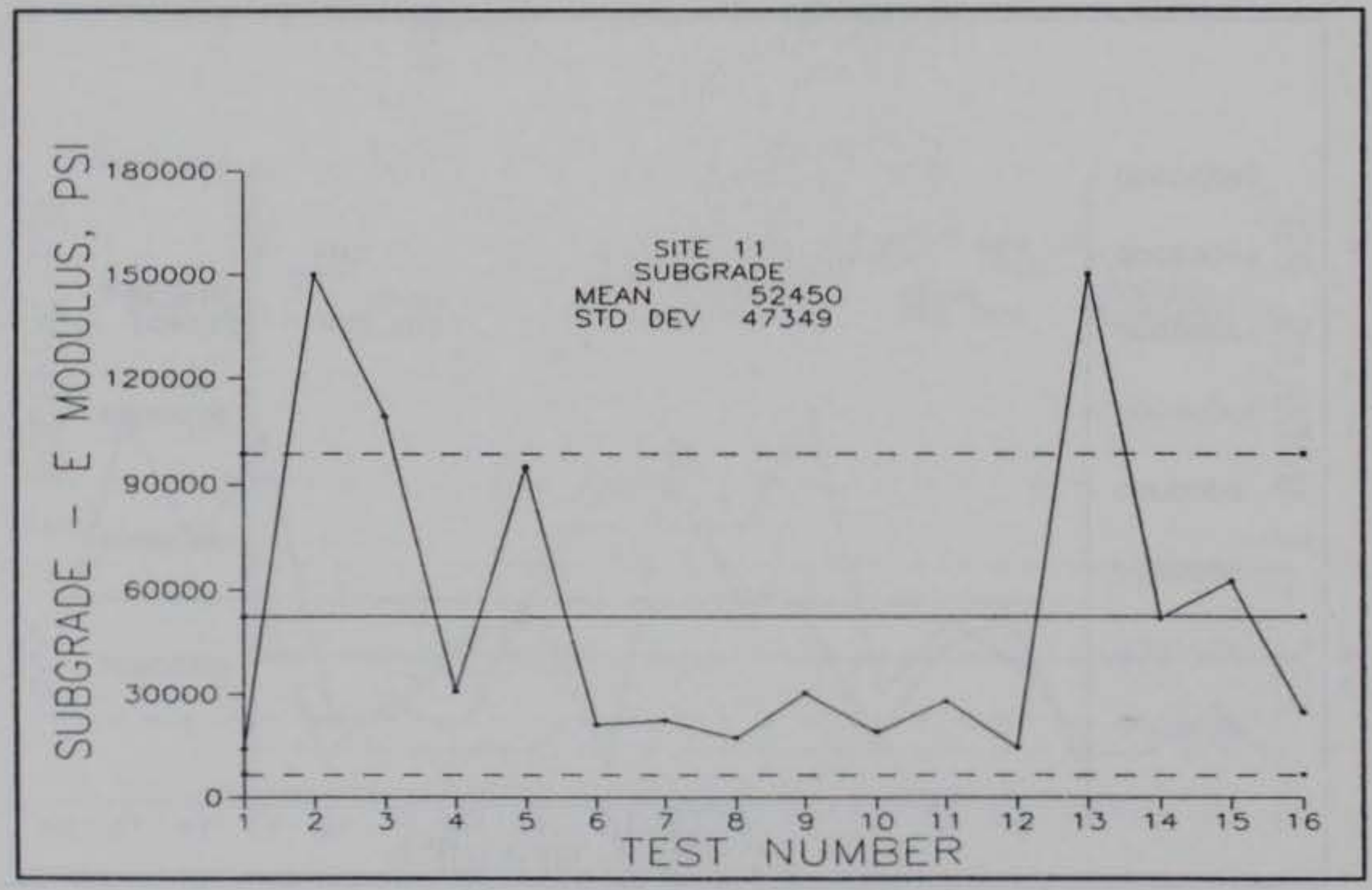

Figure 42. Site 11, Subgrade Modulus vs Test Number 


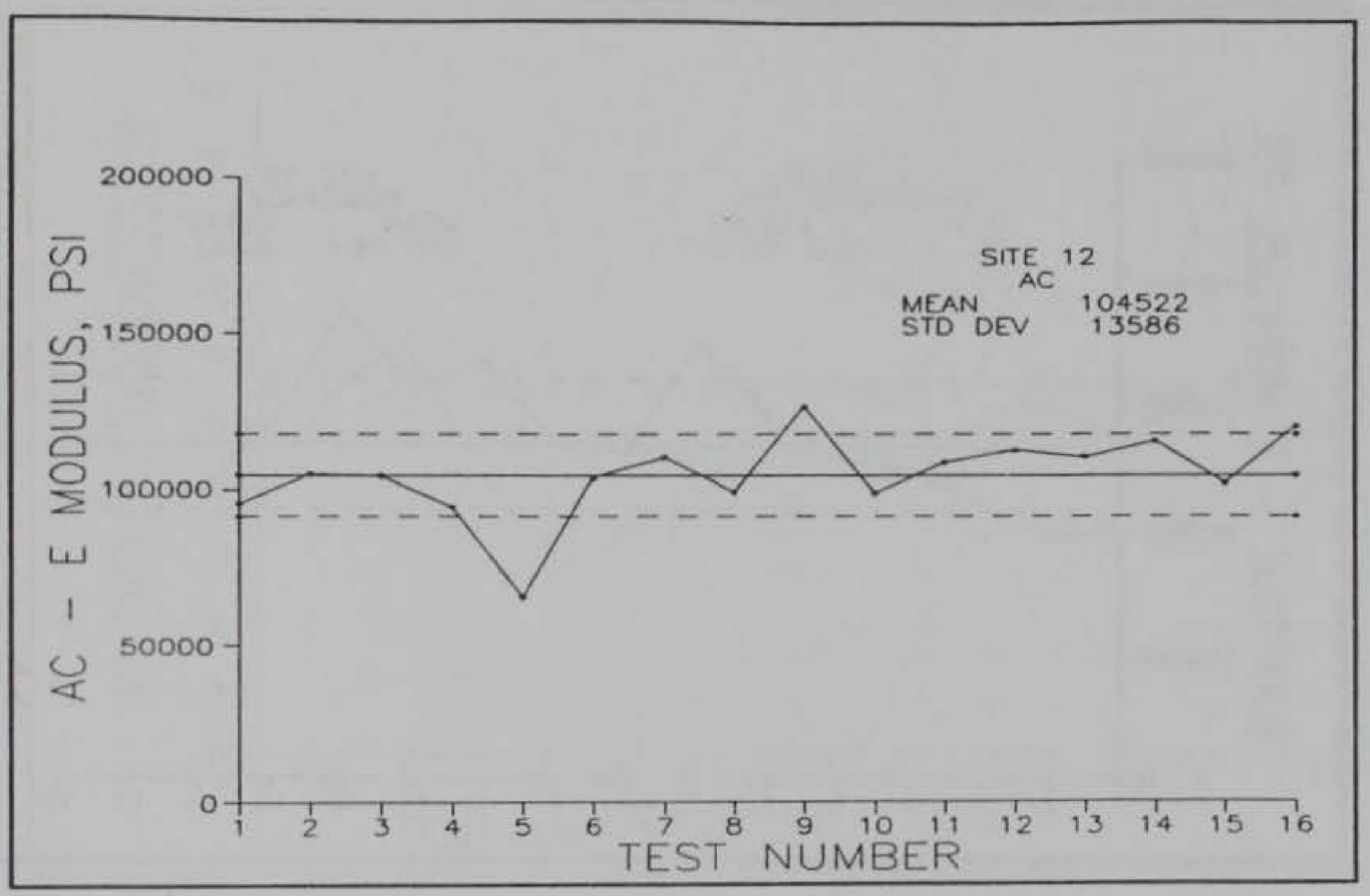

Figure 43. Site 12, AC Modulus vs Test Number

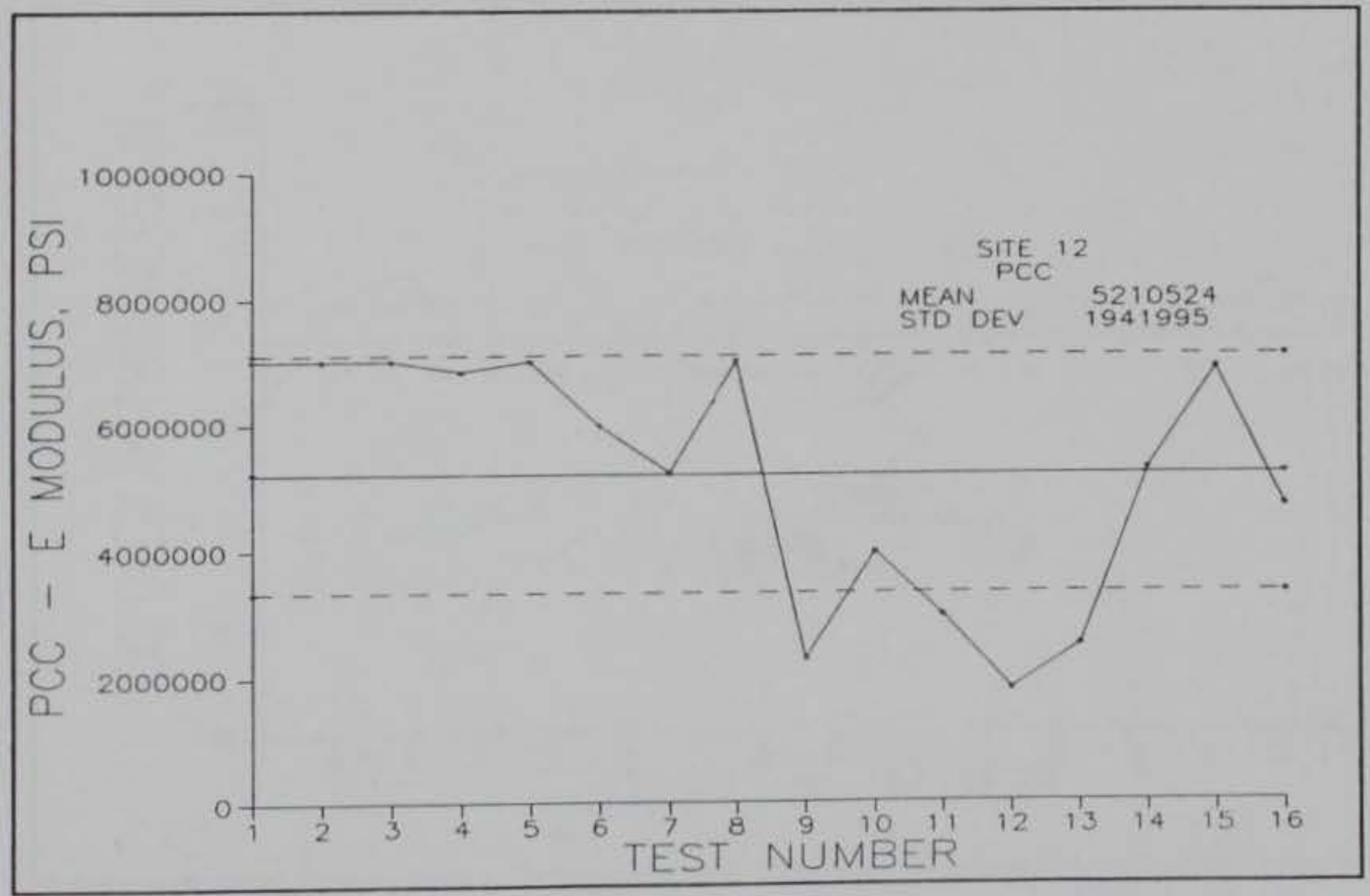

Figure 44. Site 12, PCC Modulus vs Test Number 


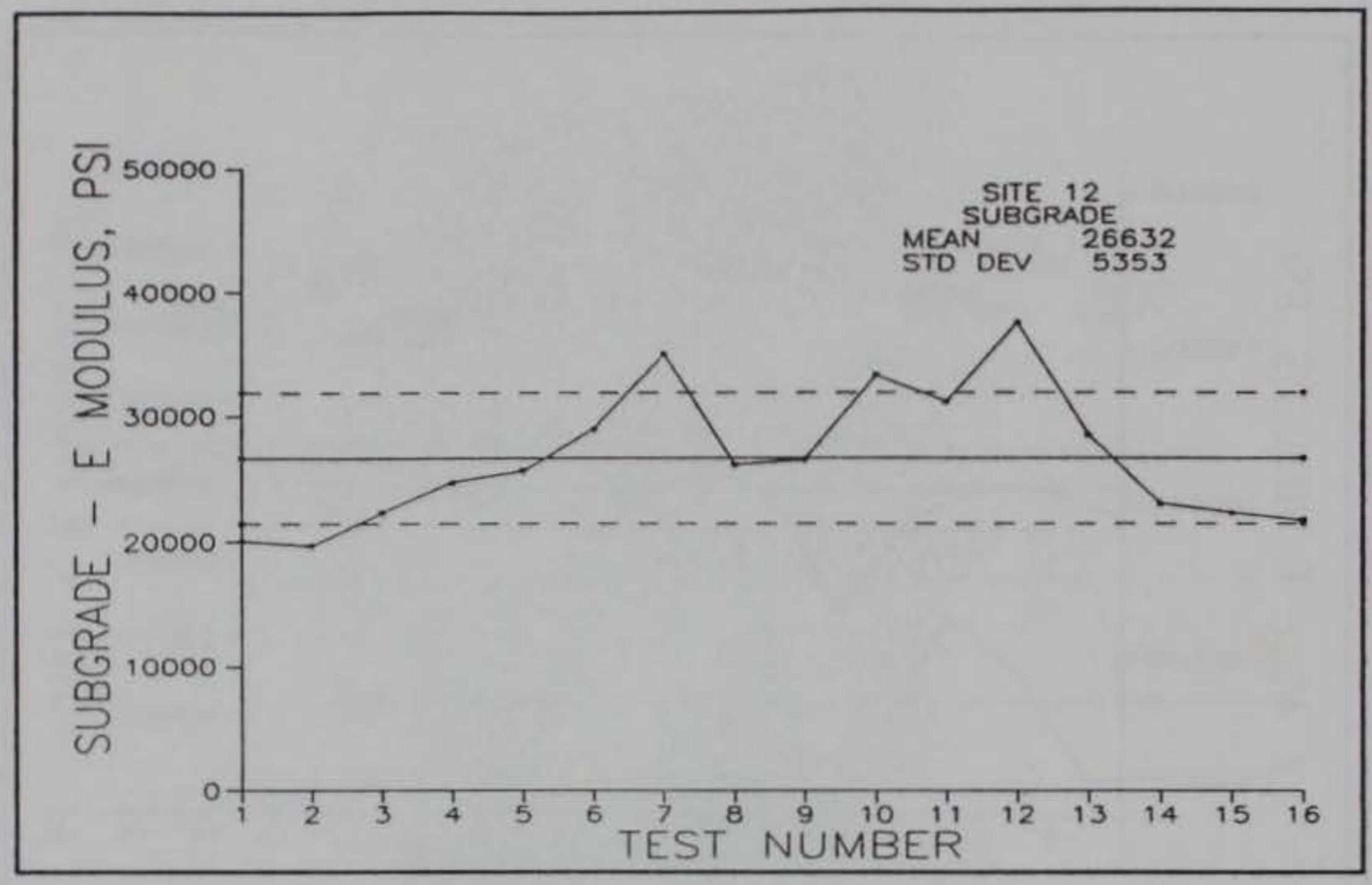

Figure 45. Site 12, Subgrade Modulus vs Test Number 


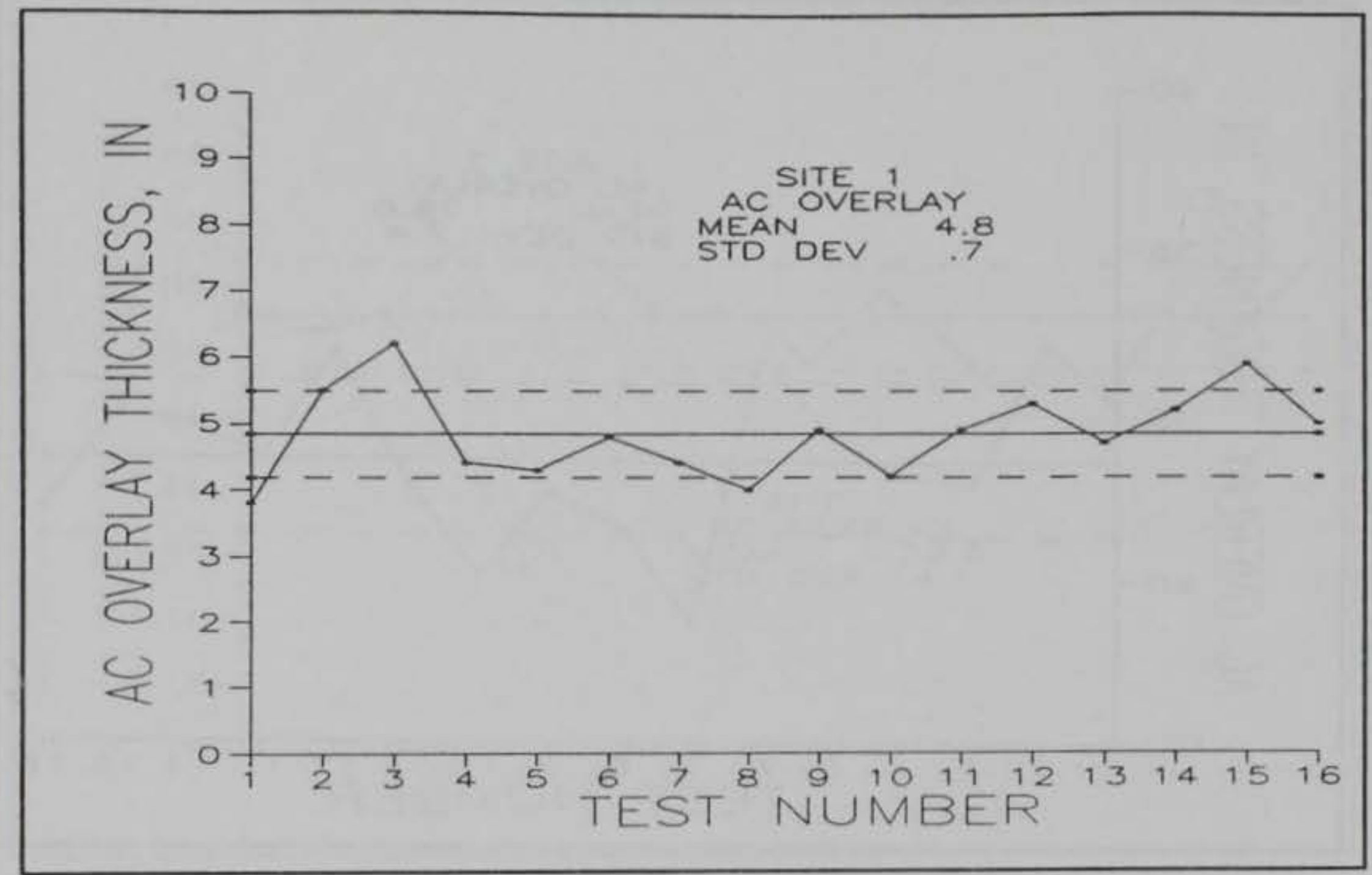

Figure 46. Site 1, AC Overlay vs Test Number

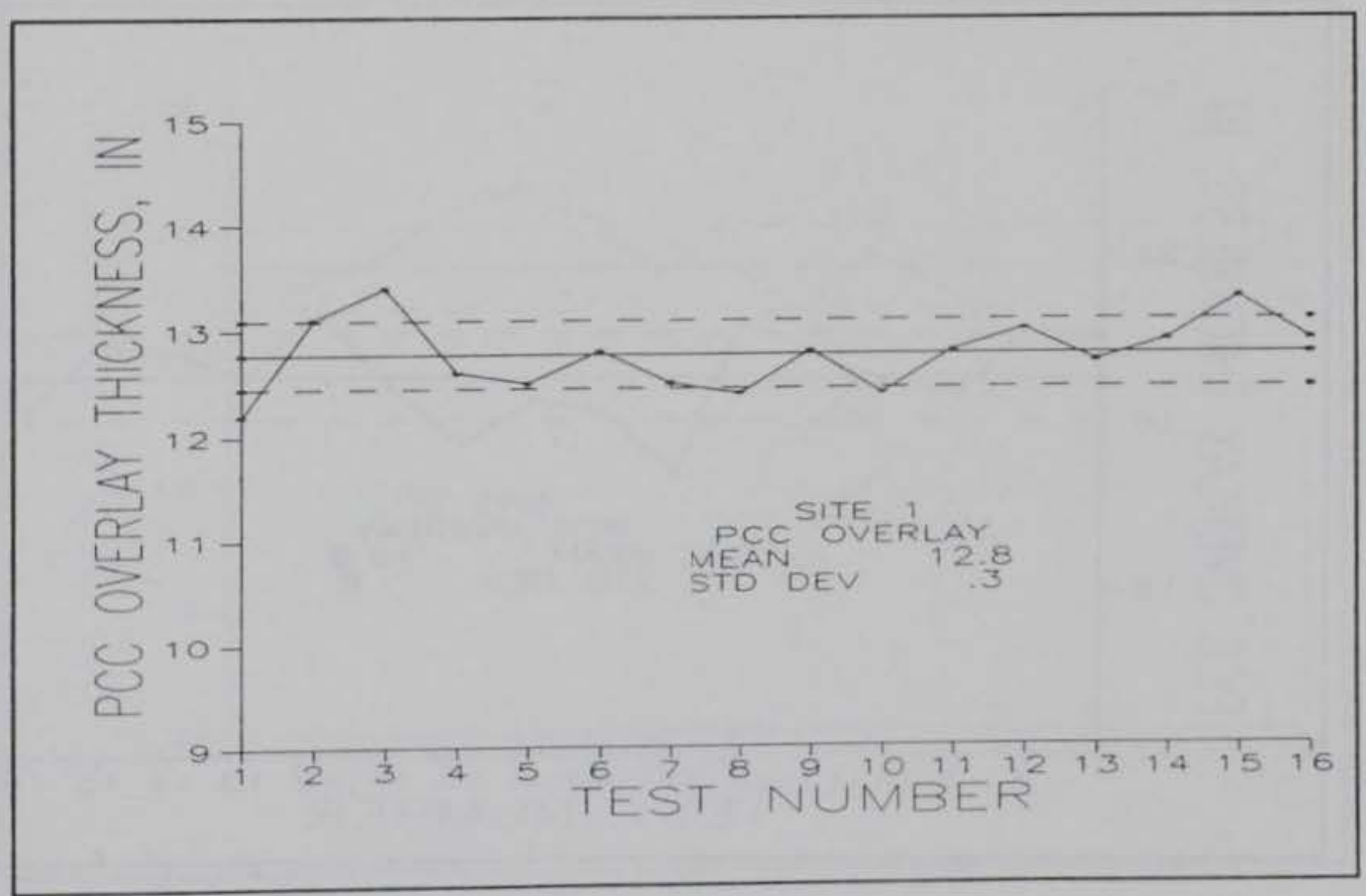

Figure 47. Site 1, PCC Overlay vs Test Number 


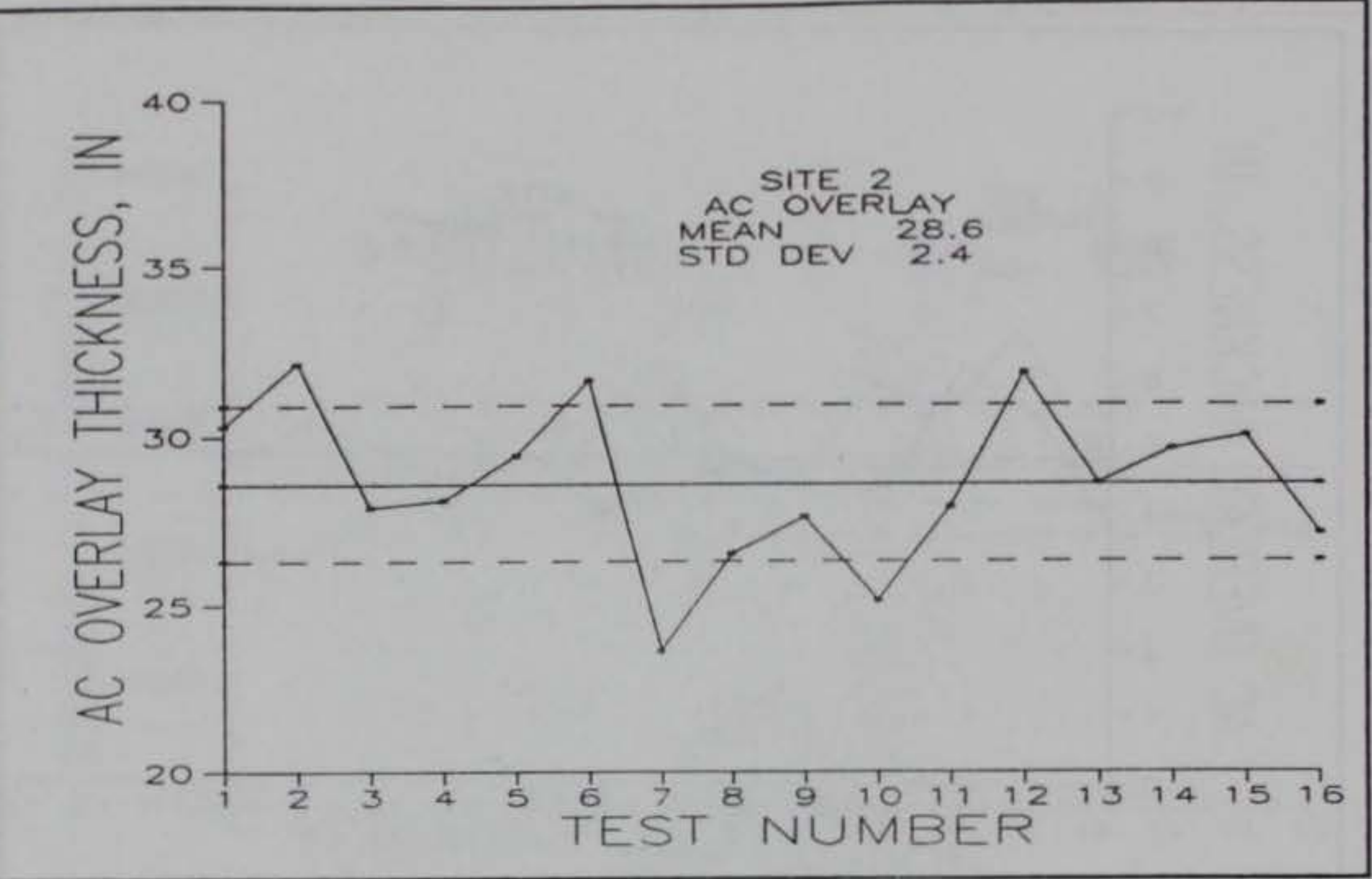

Figure 48. Site 2, AC Overlay vs Test Number

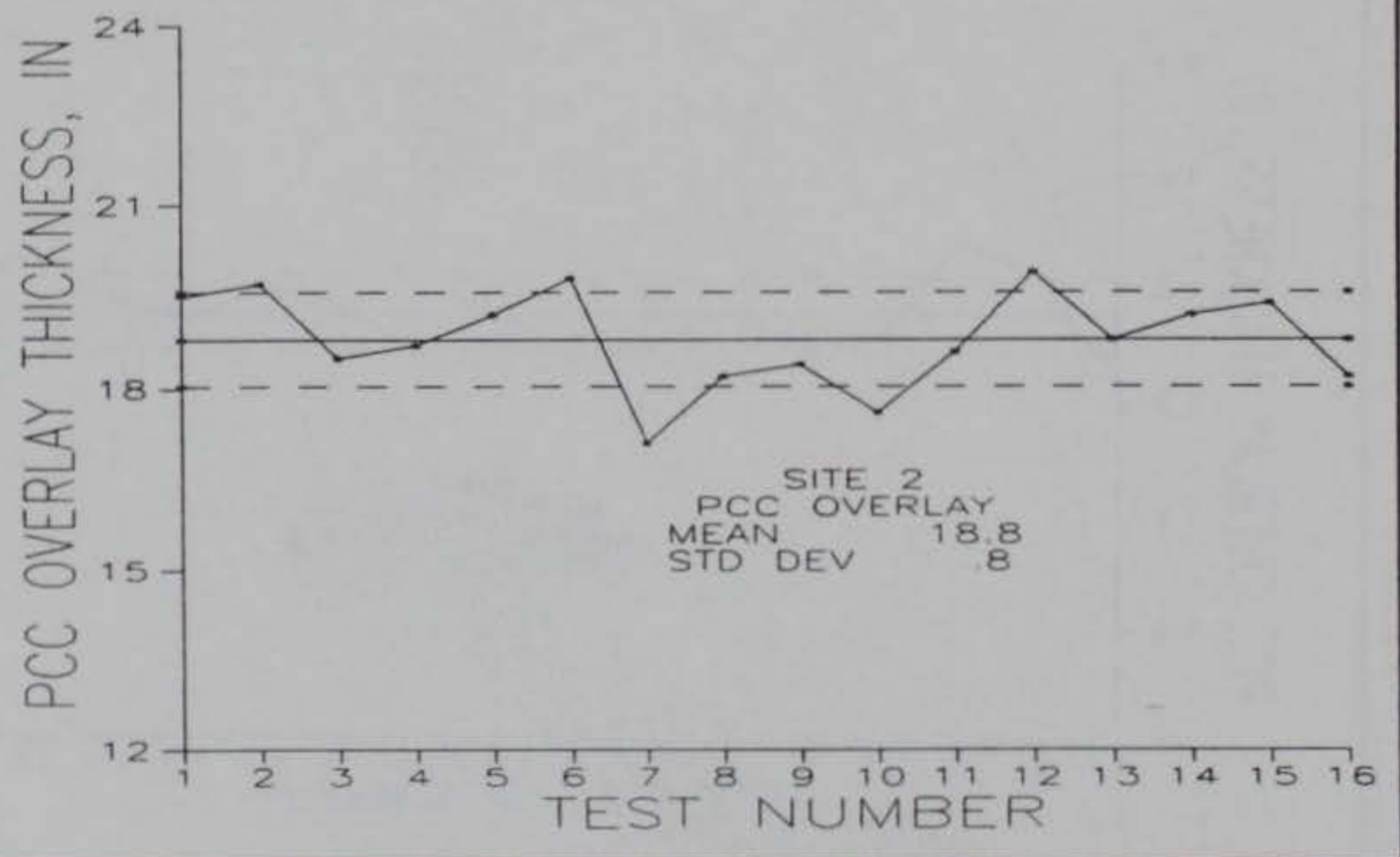

Figure 49. Site 2, PCC Overlay vs Test Number 


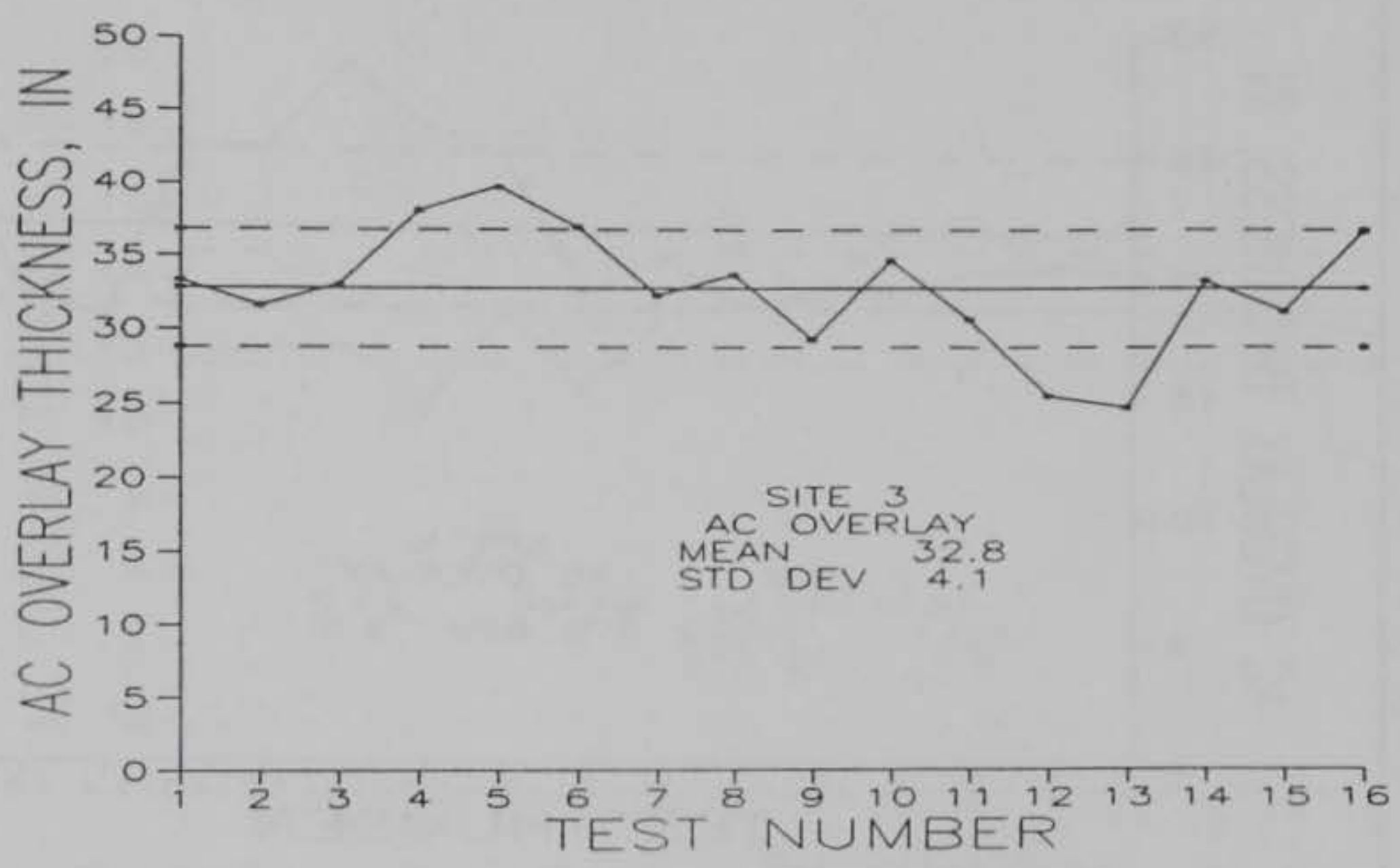

Figure 50. Site 3, AC Overlay vs Test Number

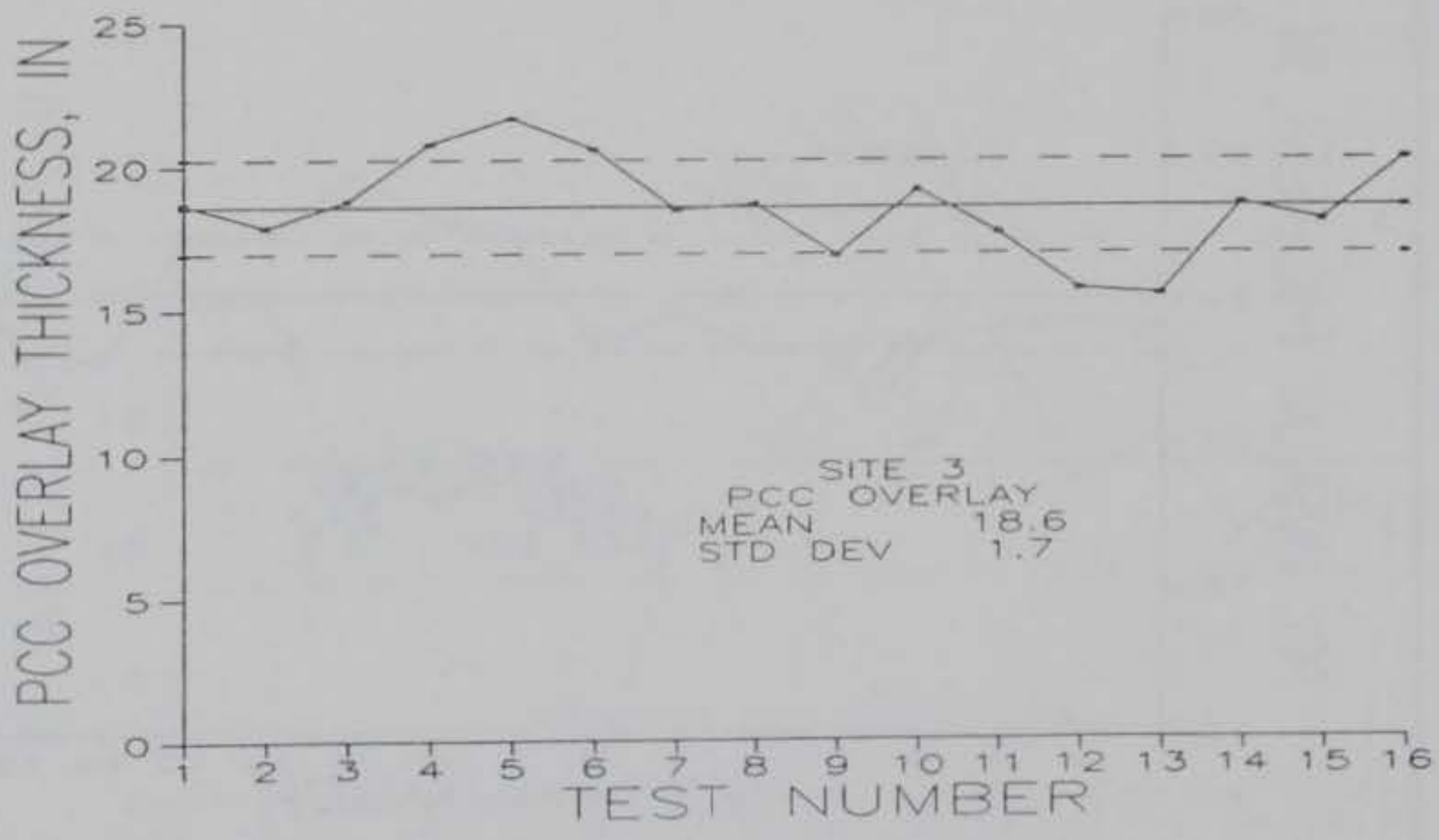

Figure 51. Site 3, PCC Overlay vs Test Number 


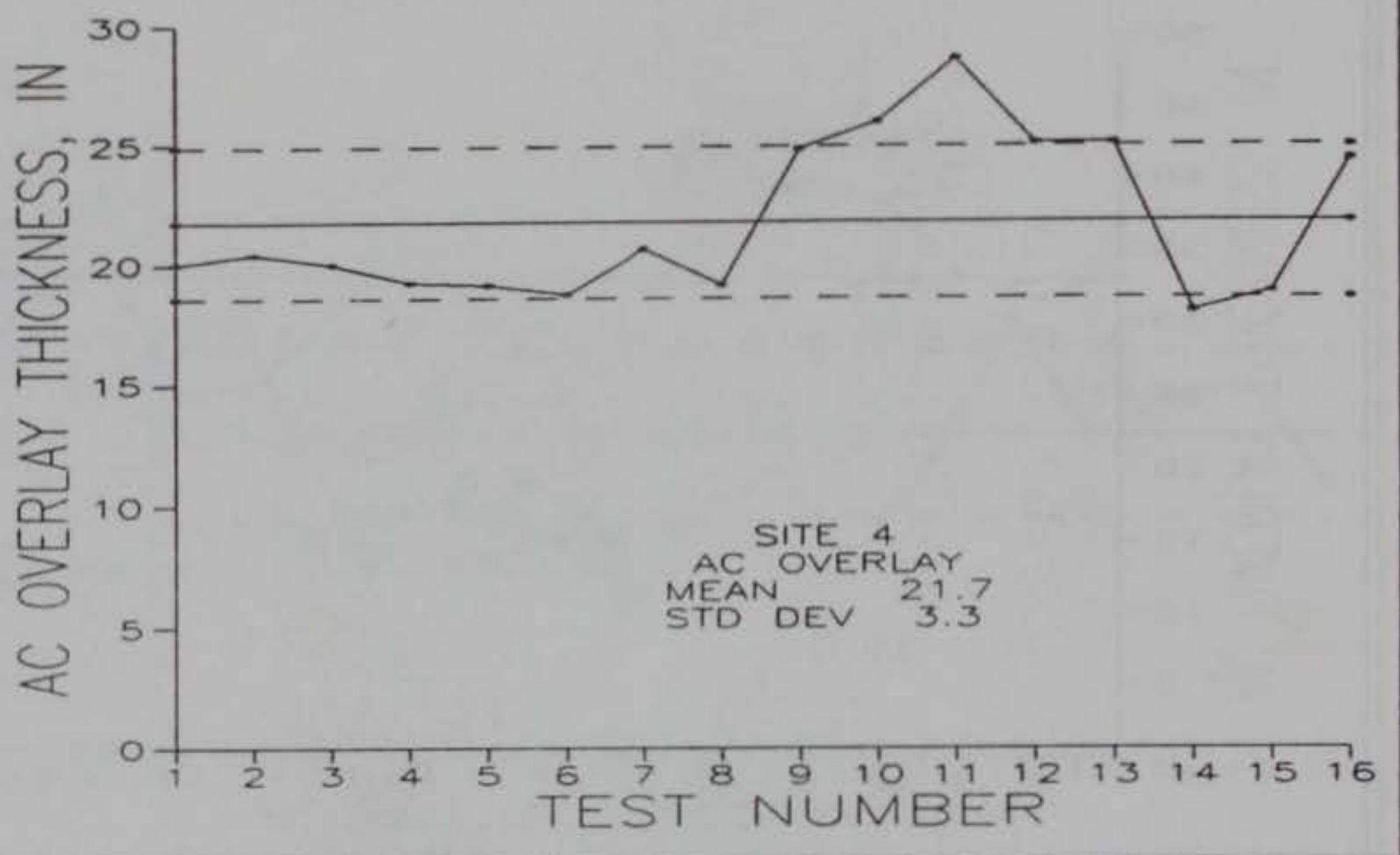

Figure 52. Site 4, AC Overlay vs Test Number

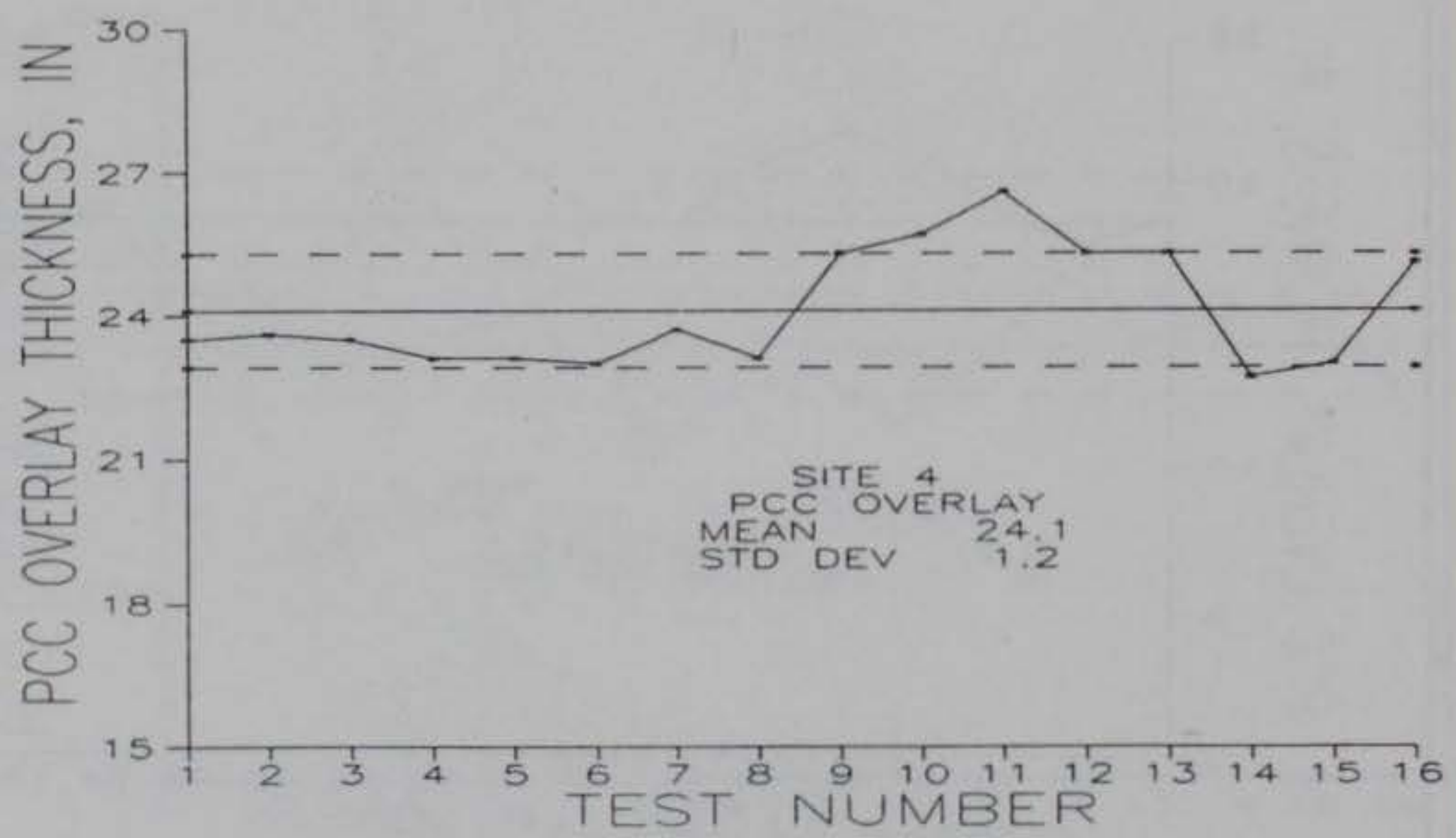

Figure 53. Site 4, PCC Overlay vs Test Number 


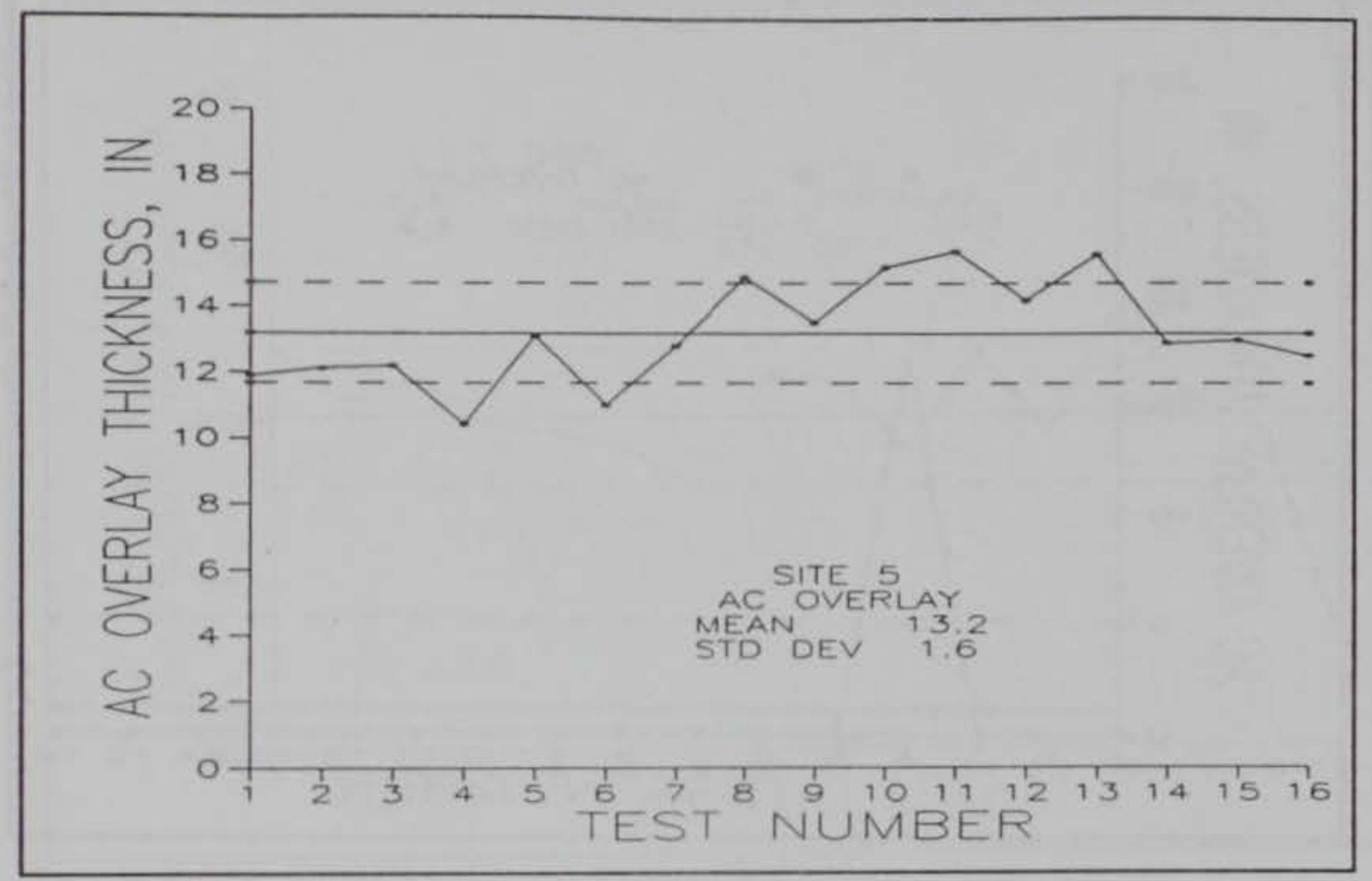

Figure 54. Site 5, AC Overlay vs Test Number

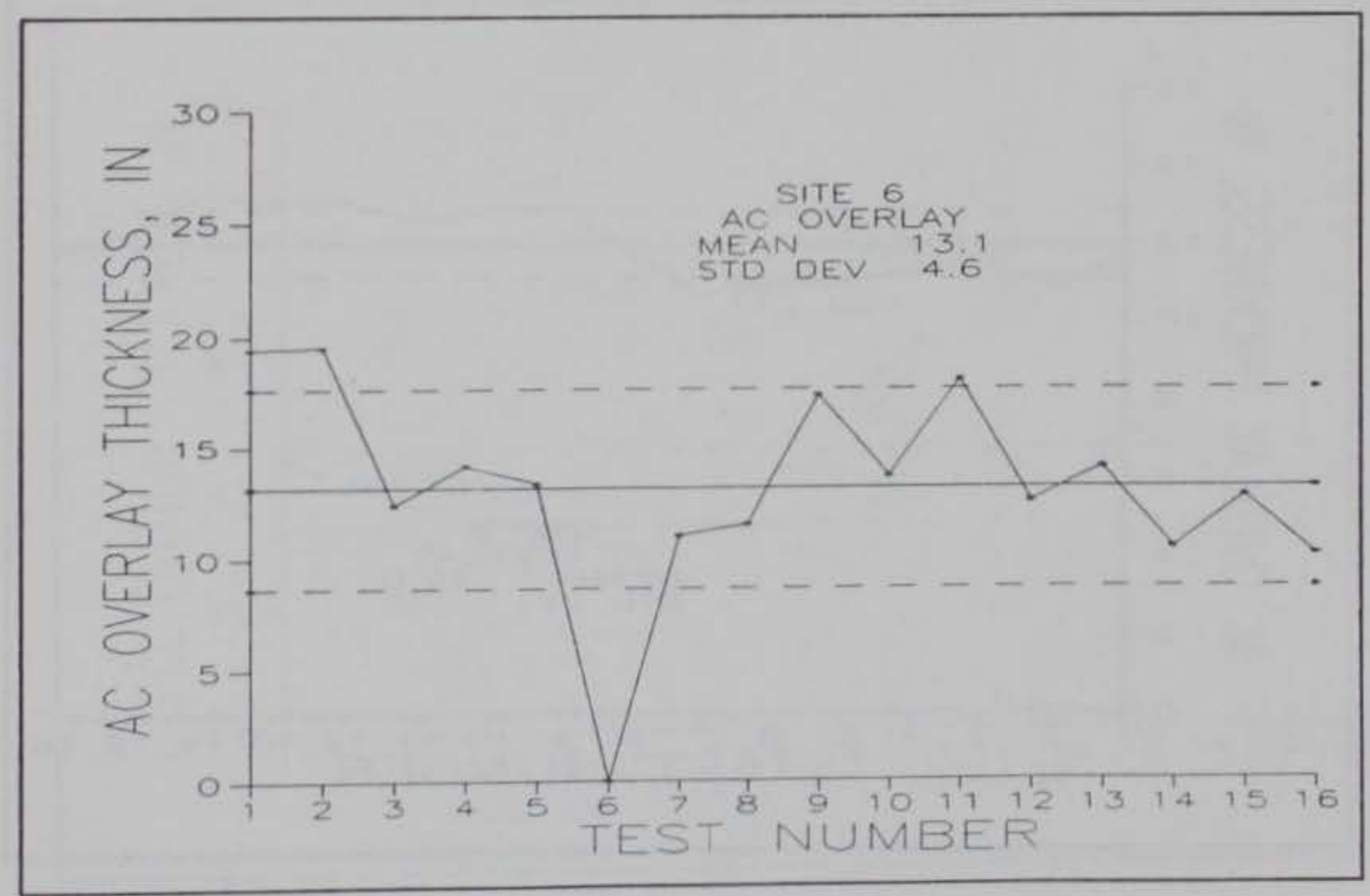

Figure 55. Site 6, AC Overlay vs Test Number 


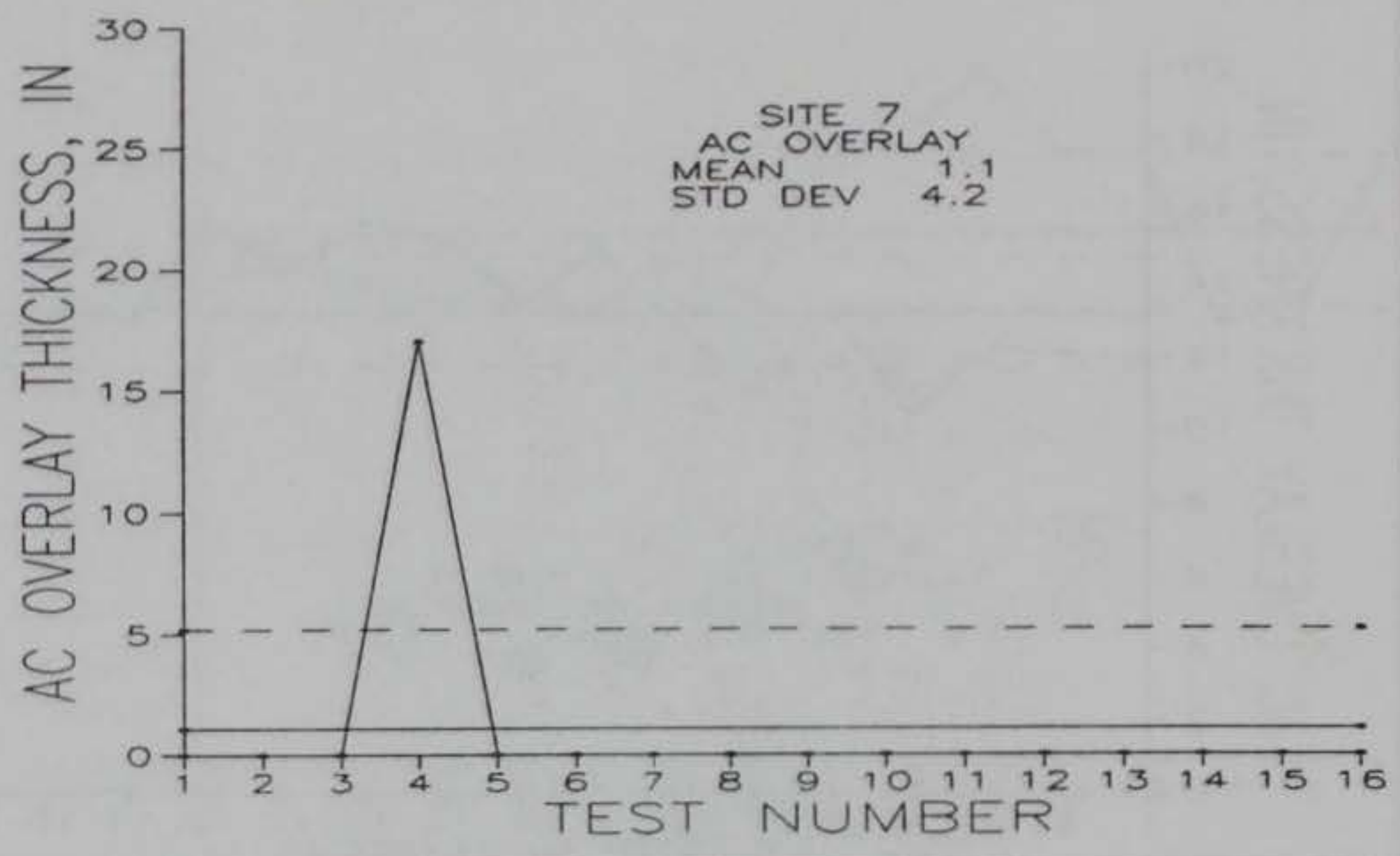

Figure 56. Site 7, AC Overlay vs Test Number

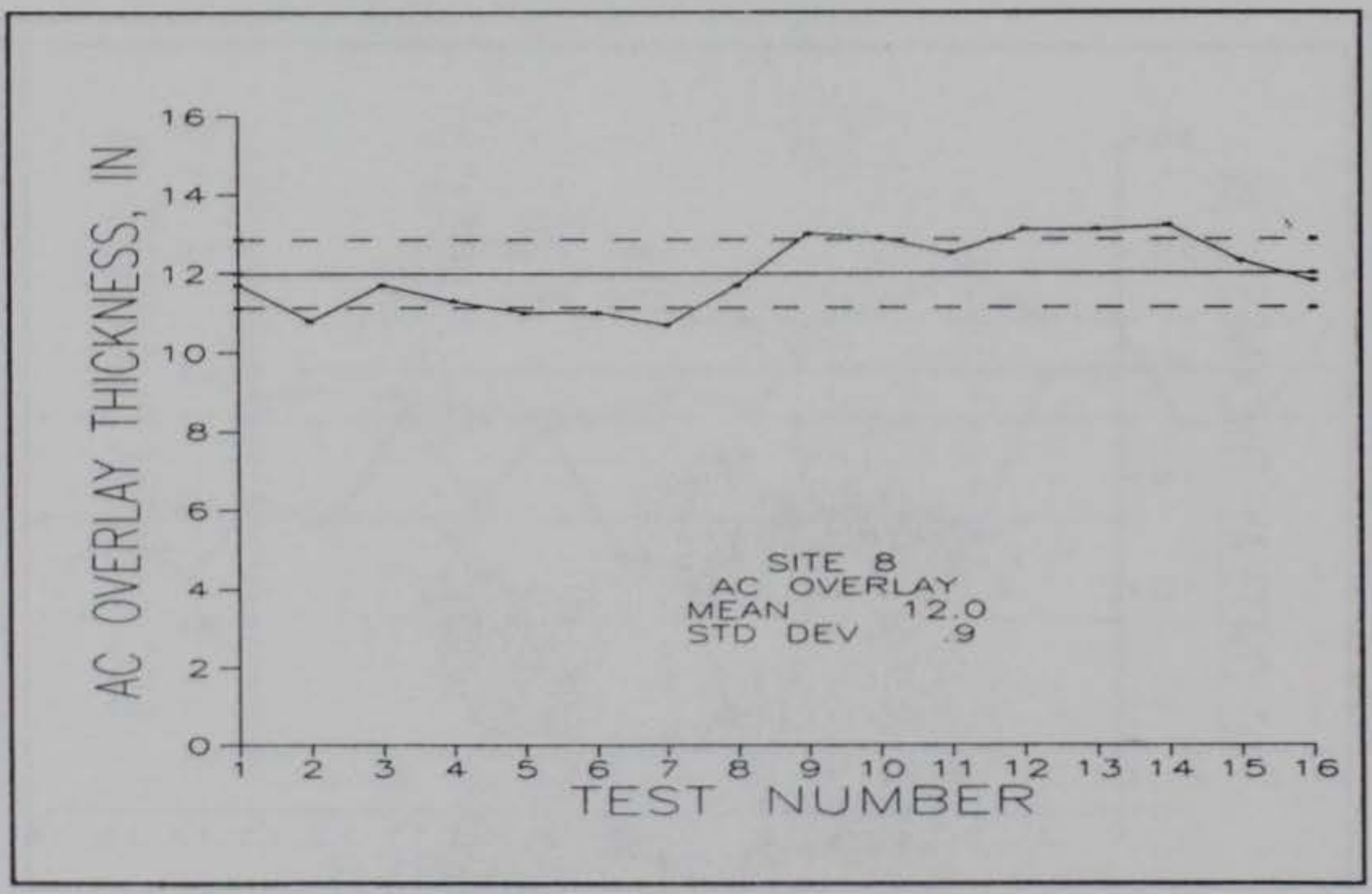

Figure 57. Site 8, AC Overlay vs Test Number 


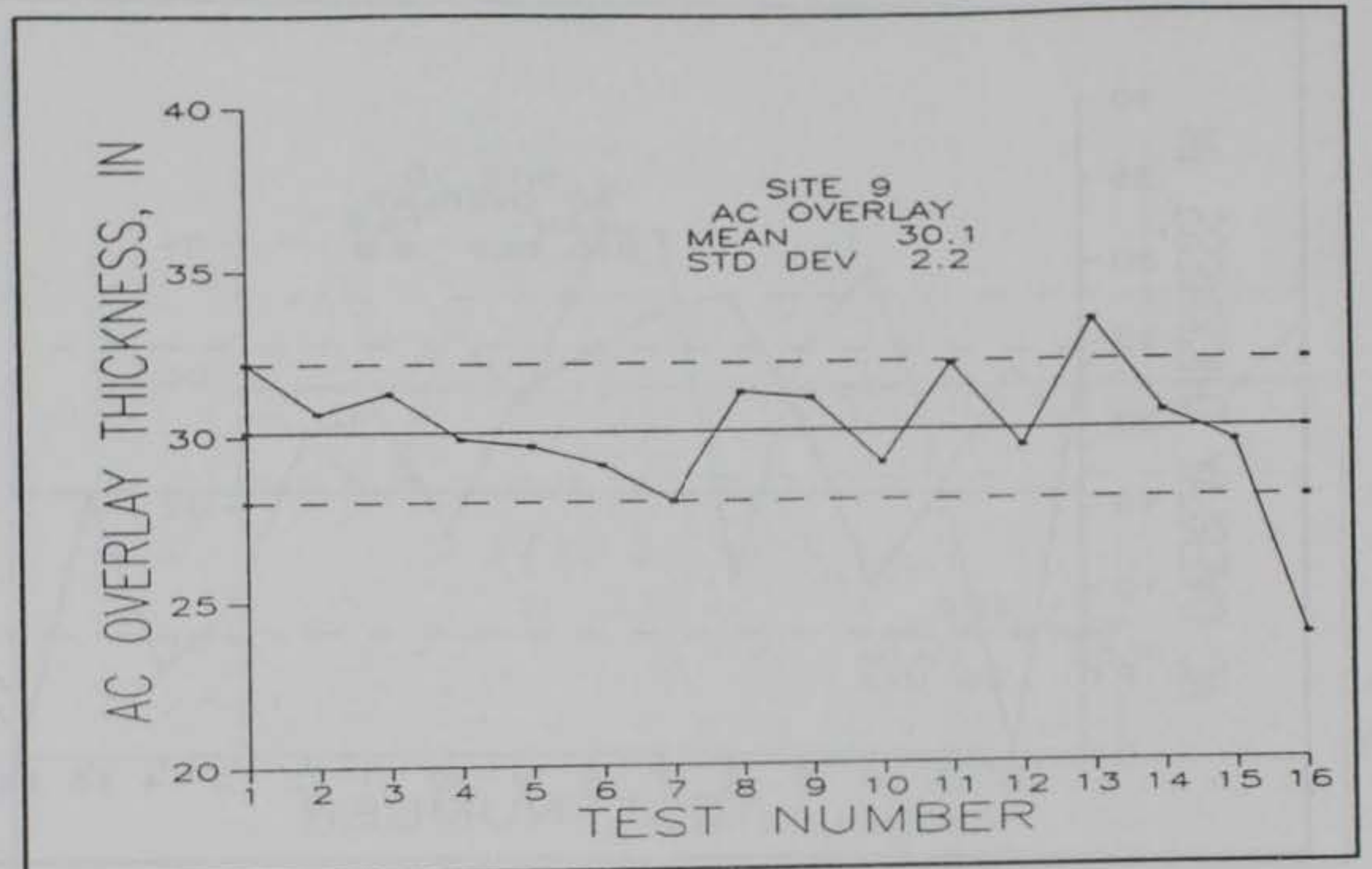

Figure 58. Site 9, AC Overlay vs Test Number

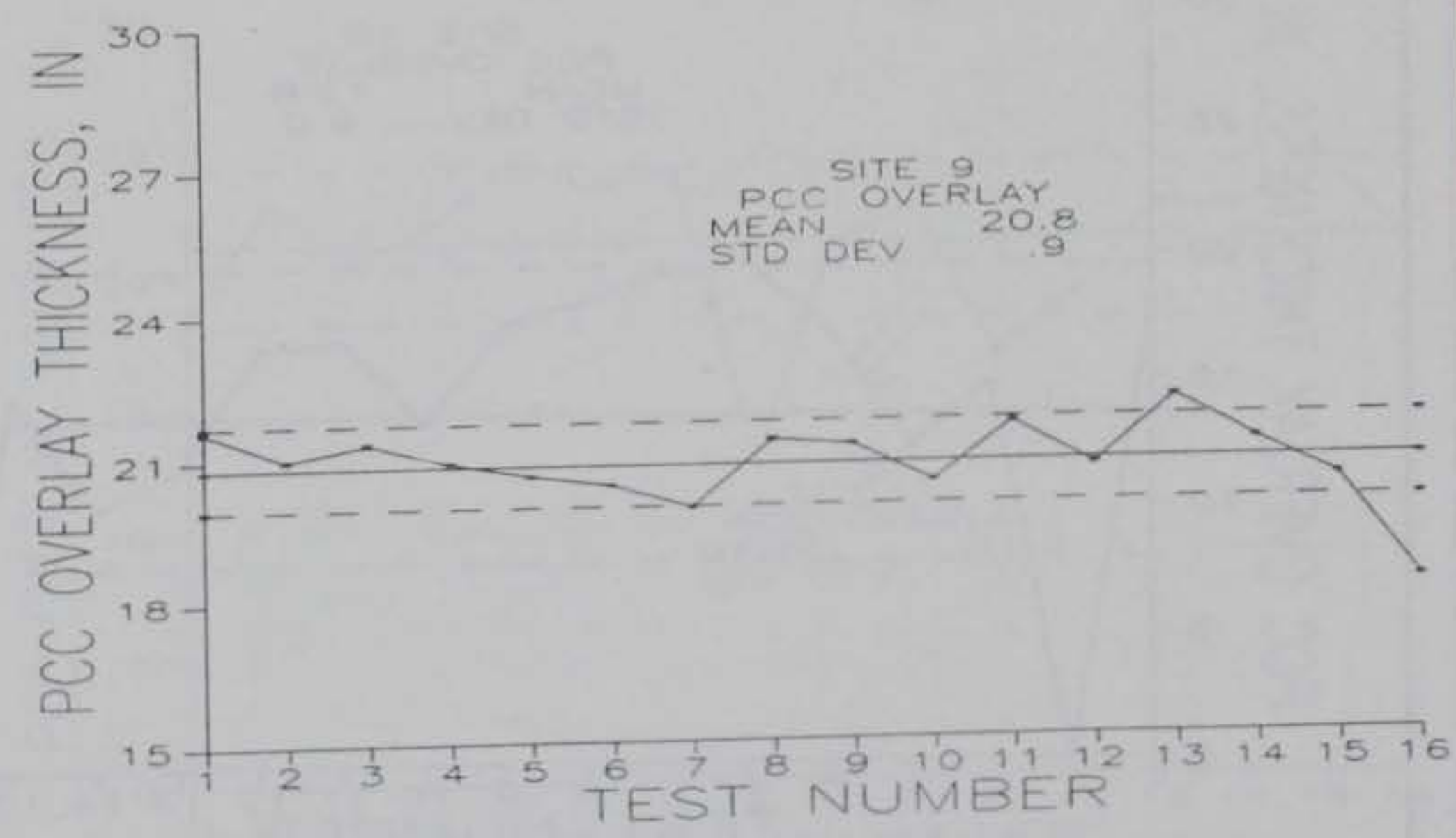

Figure 59. Site 9, PCC Overlay vs Test Number 


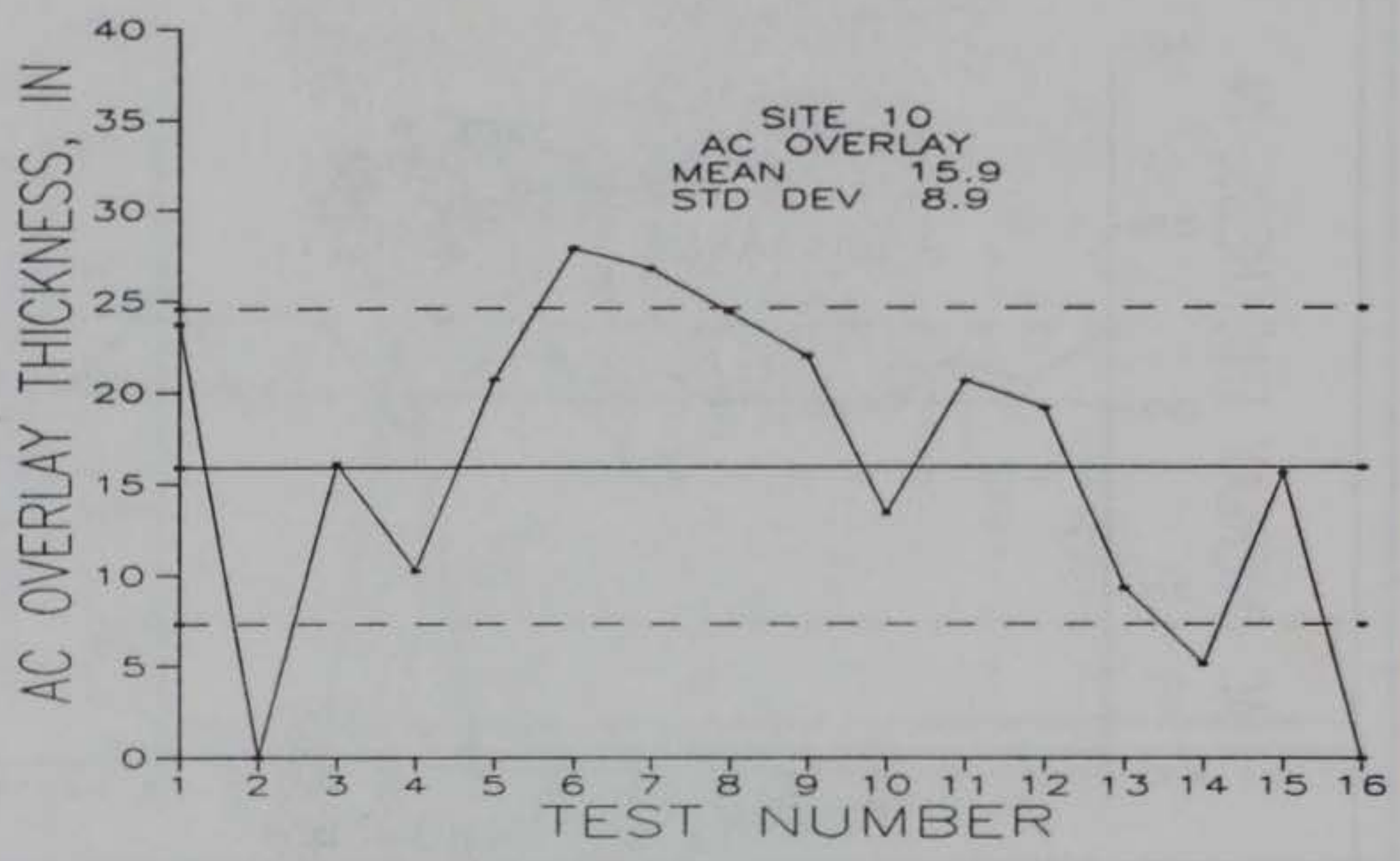

Figure 60. Site 10, AC Overlay vs Test Number

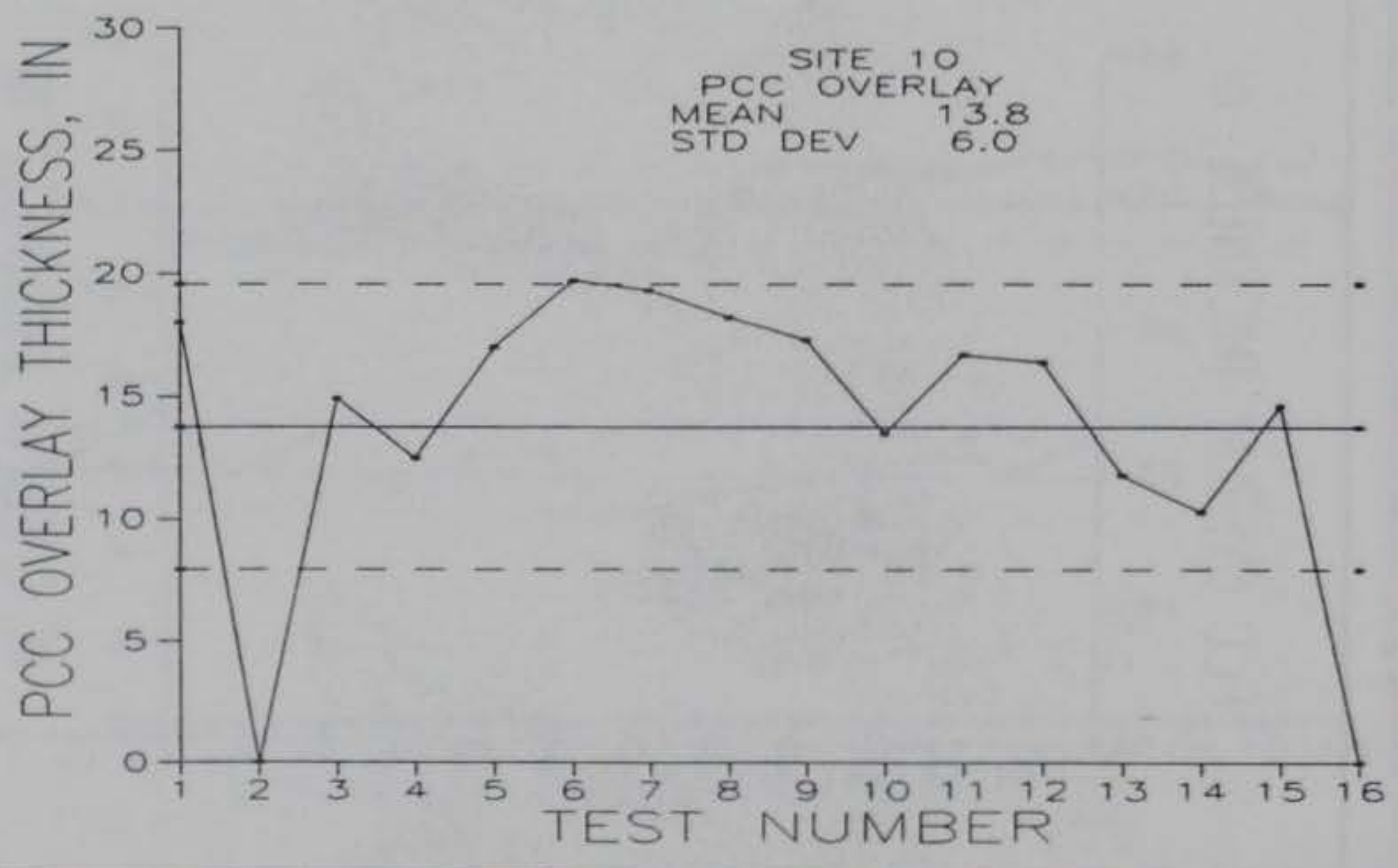

Figure 61. Site 10, PCC Overlay vs Test Number 


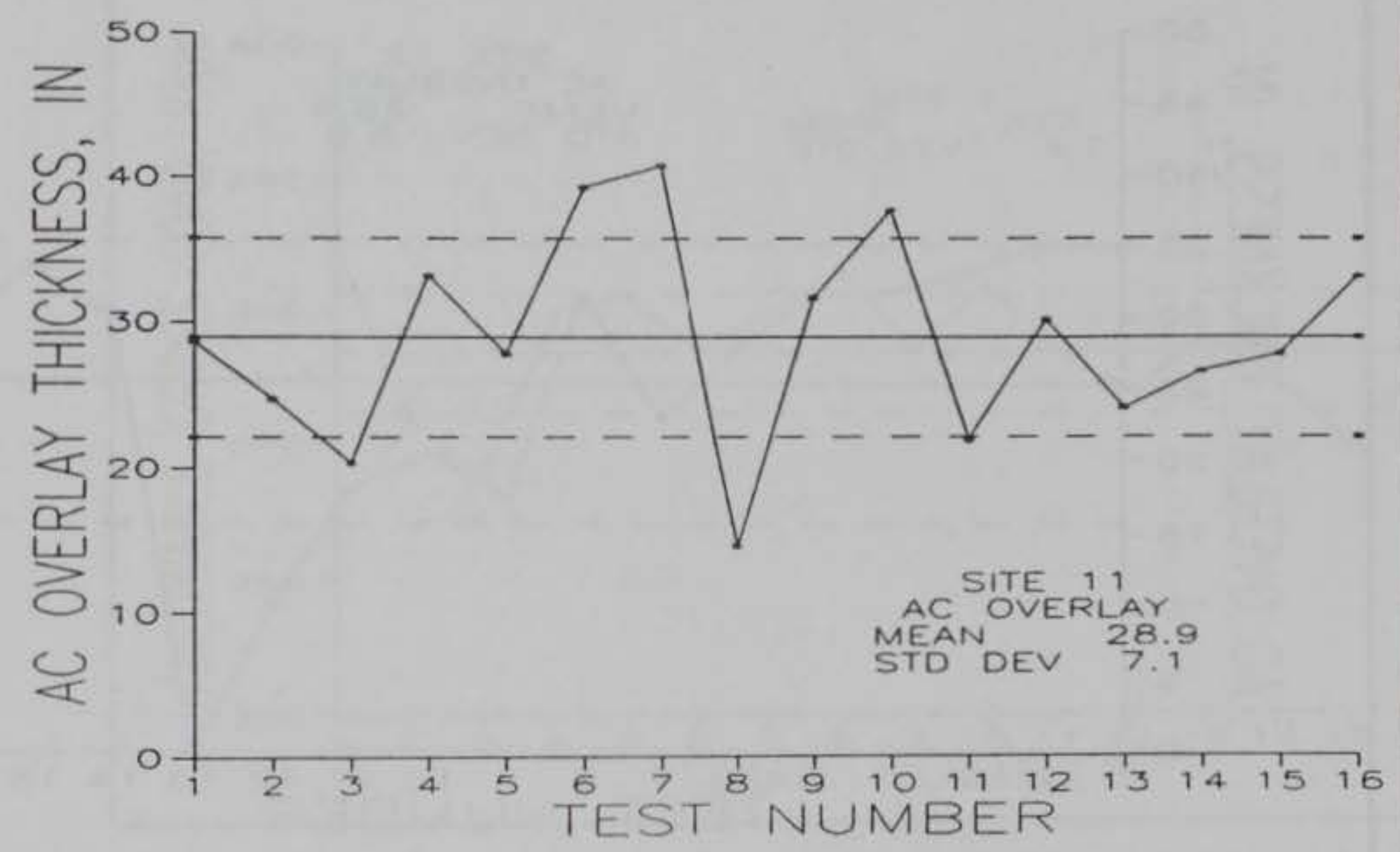

Figure 62. Site 11, AC Overlay vs Test Number

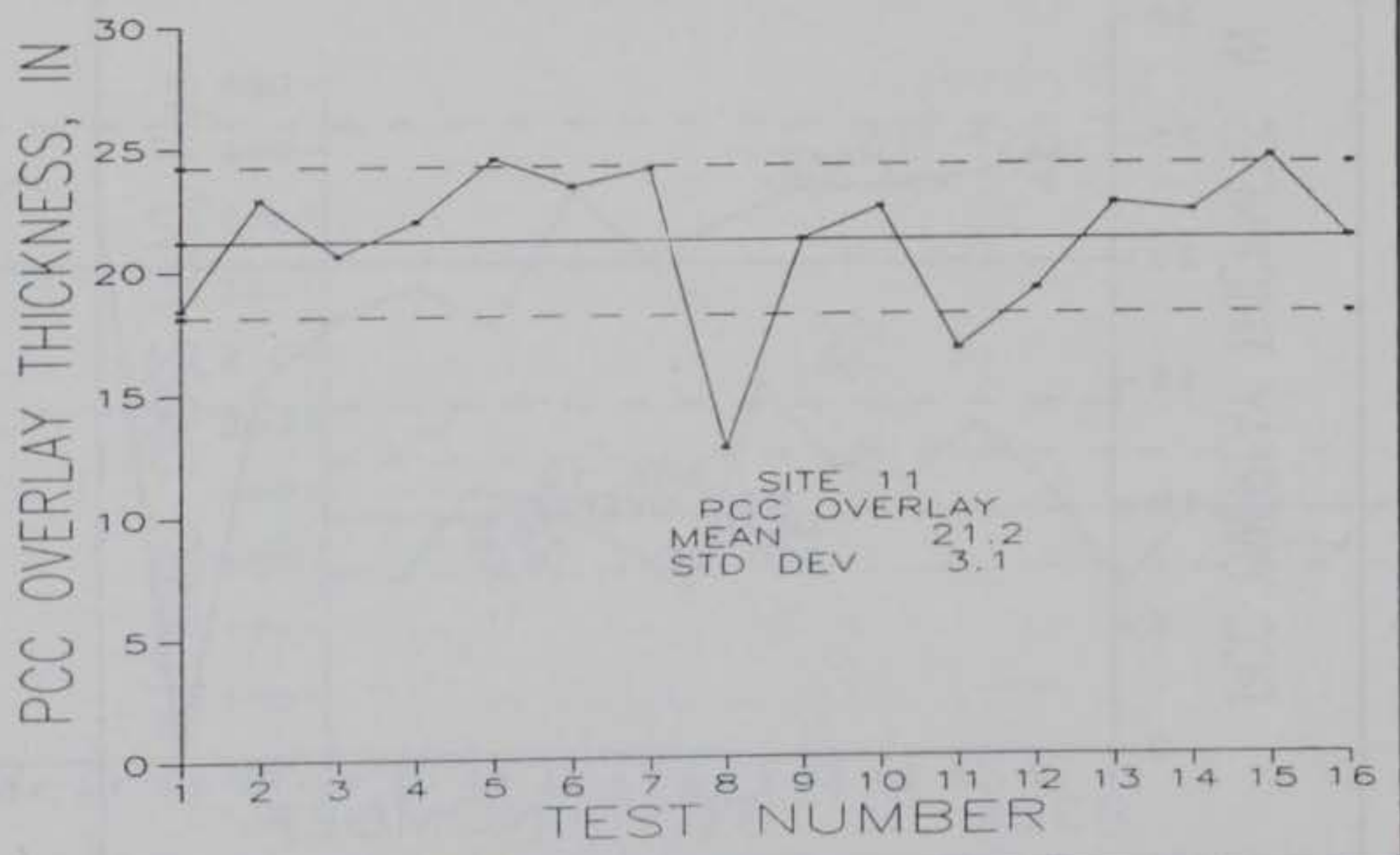

Figure 63. Site 11, PCC Overlay vs Test Number 


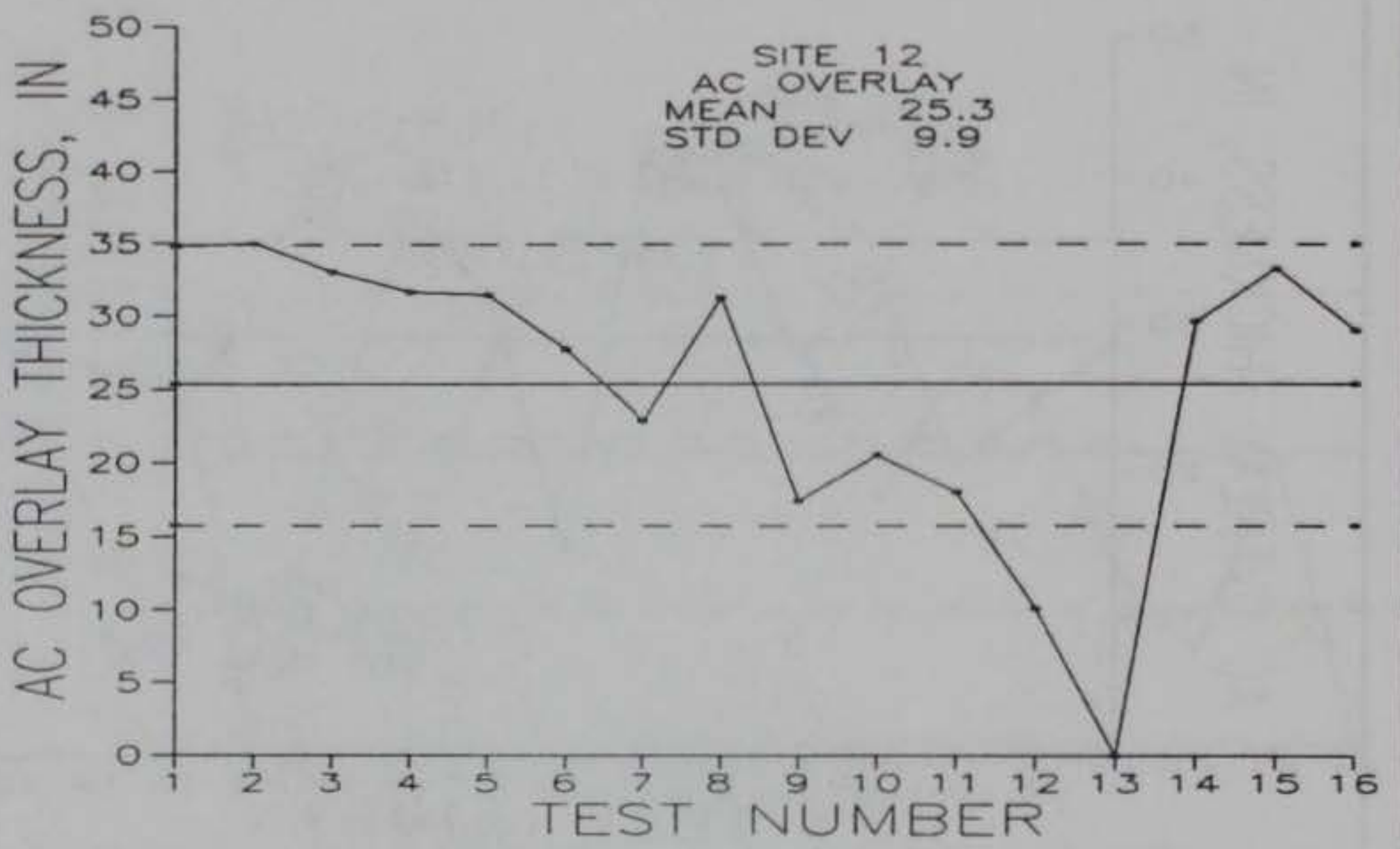

Figure 64. Site 12, AC Overlay vs Test Number

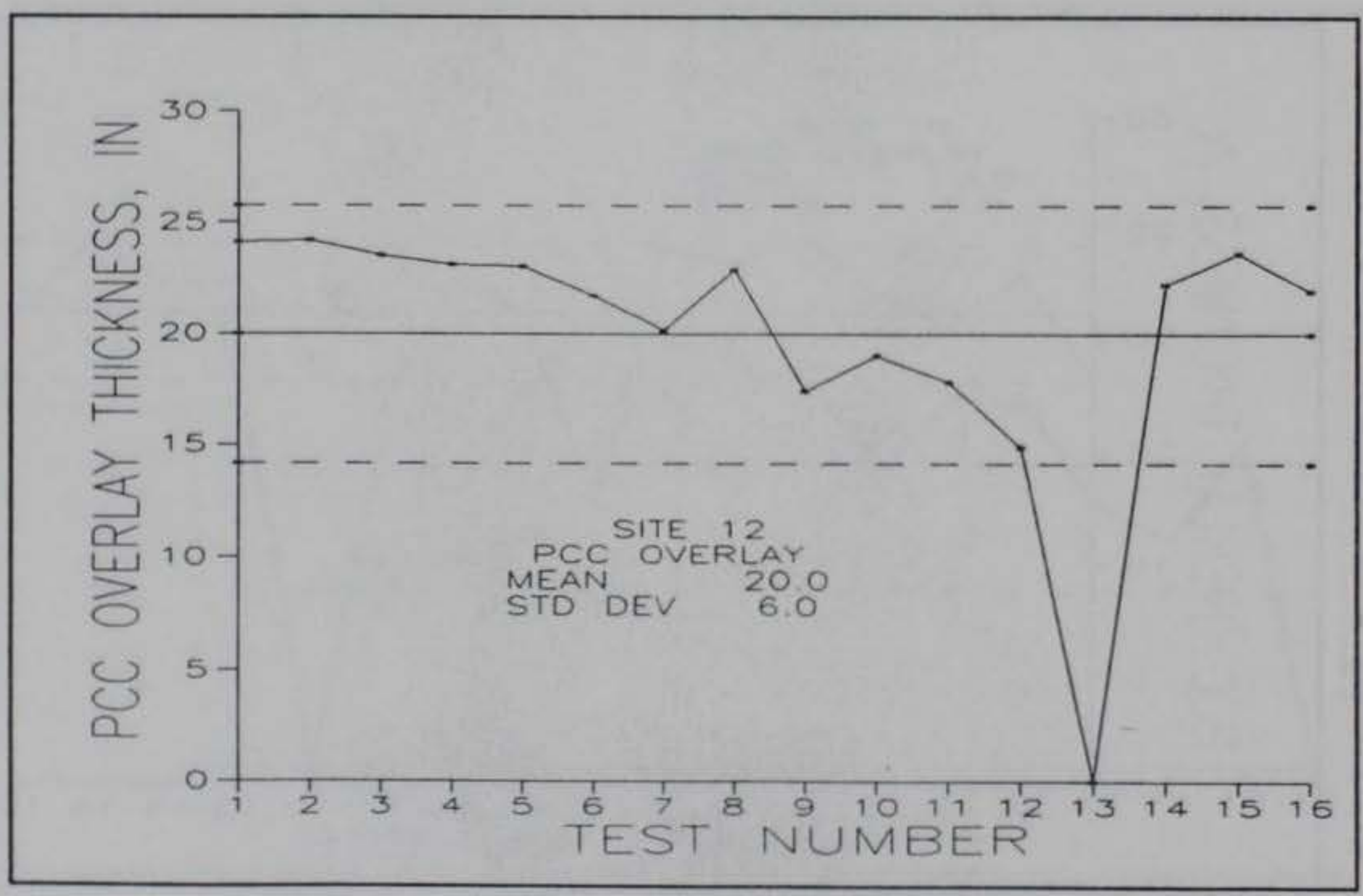

Figure 65. Site 12, PCC Overlay vs Test Number 


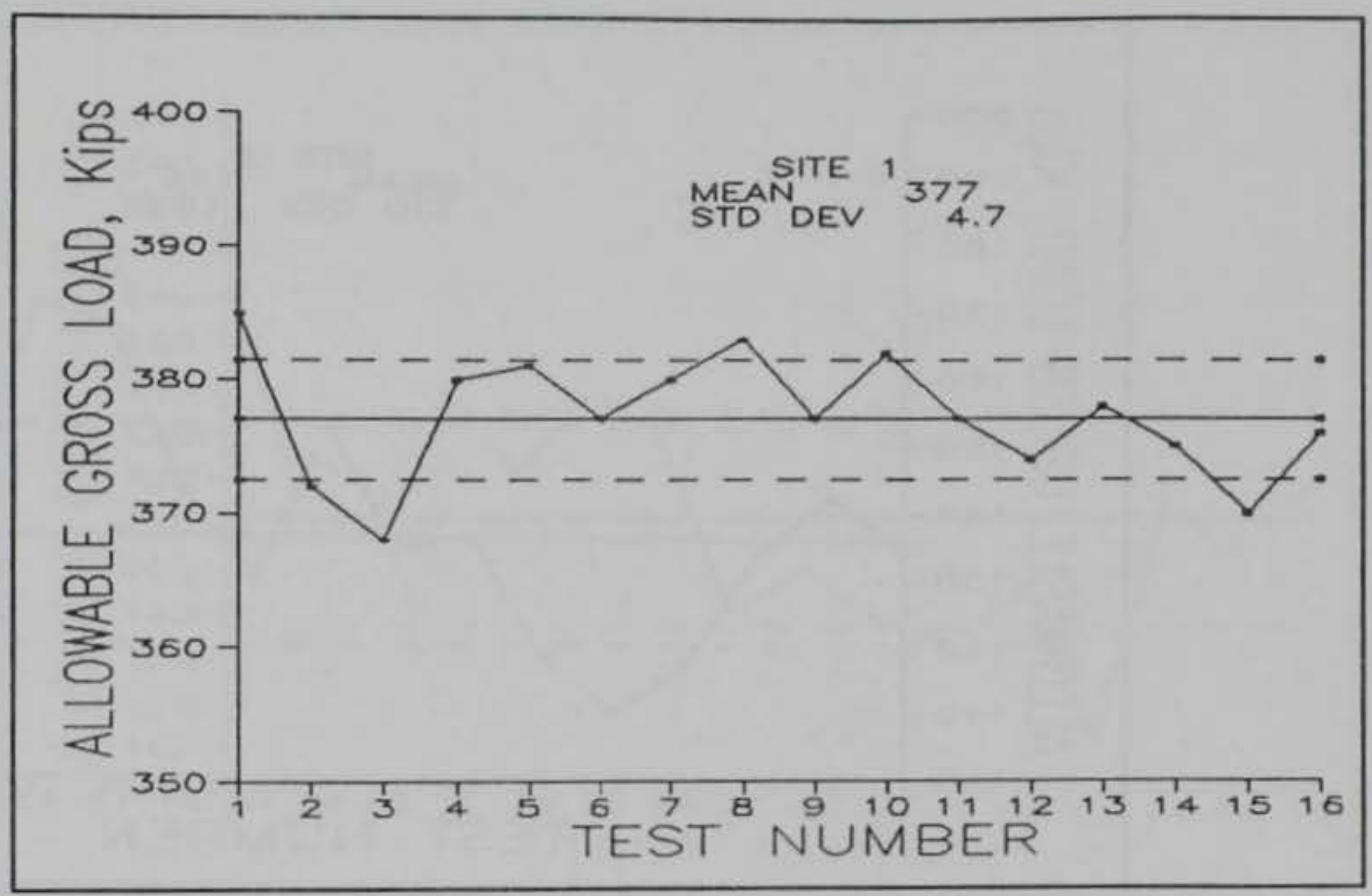

Figure 66 .

Site 1, Allowable Gross Load vs Test Number

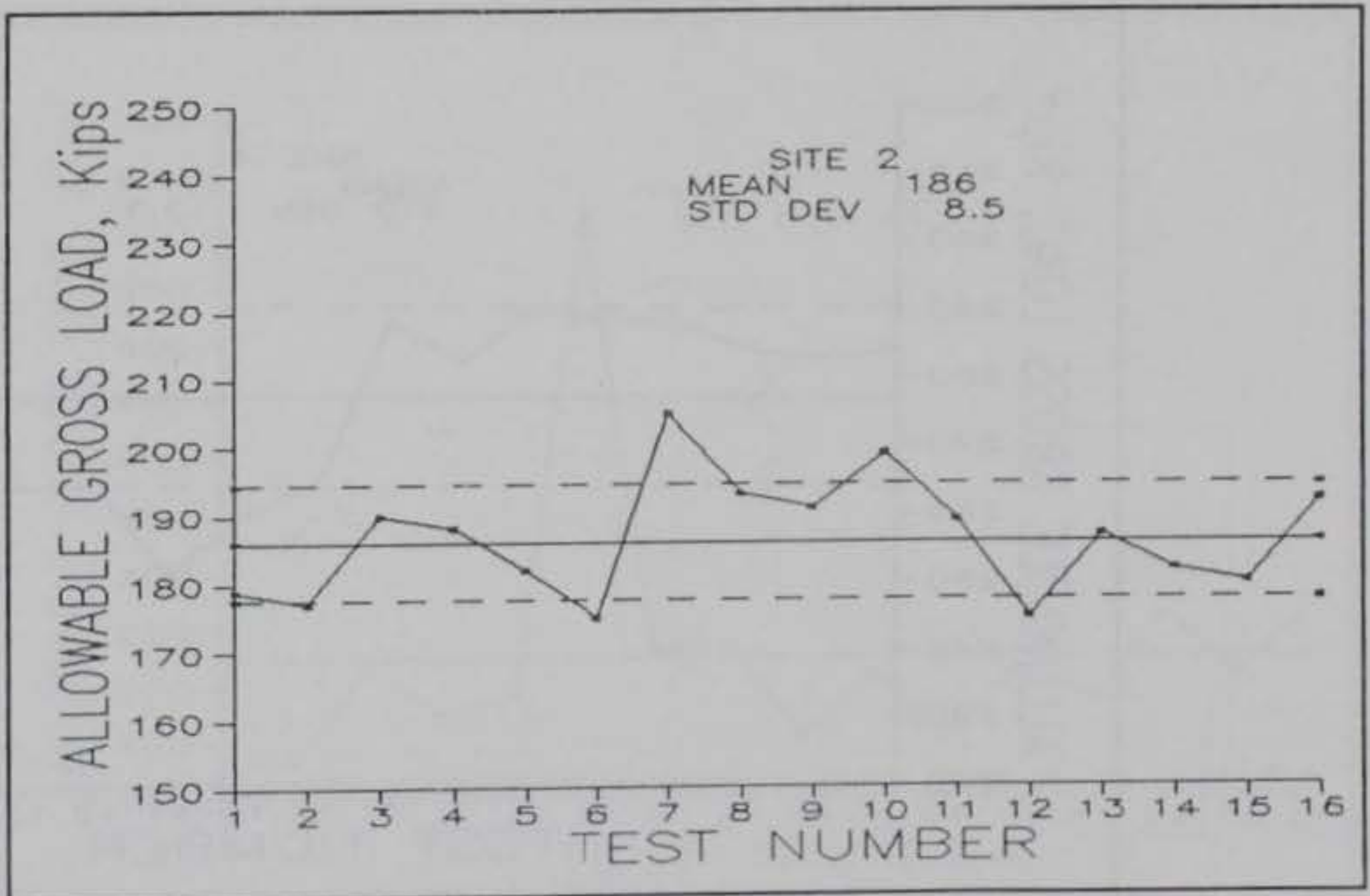

Figure 67.

Site 2, Allowable Gross Load vs Test Number 


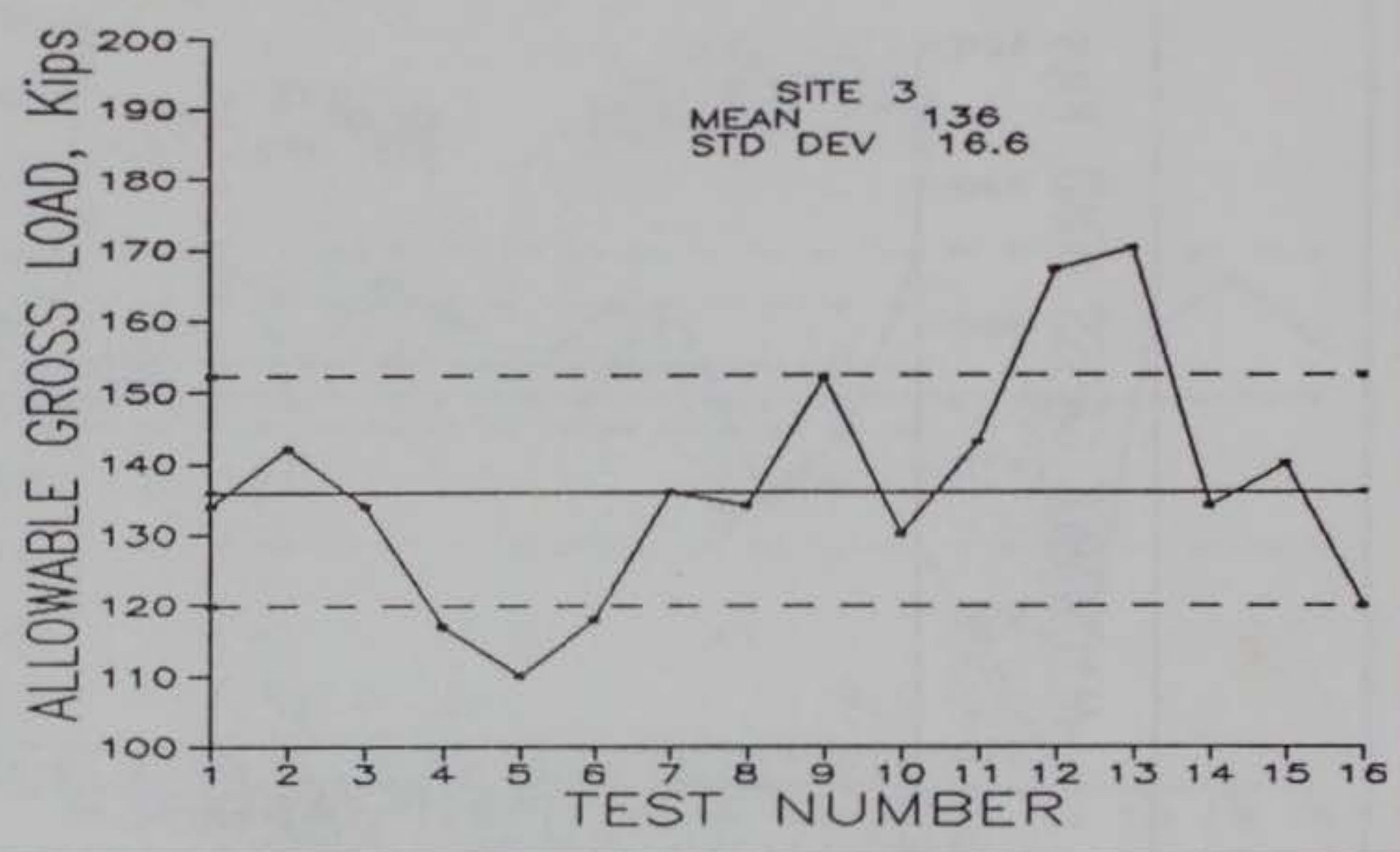

Figure 68 .

Site 3, Allowable Gross Load vs Test Number

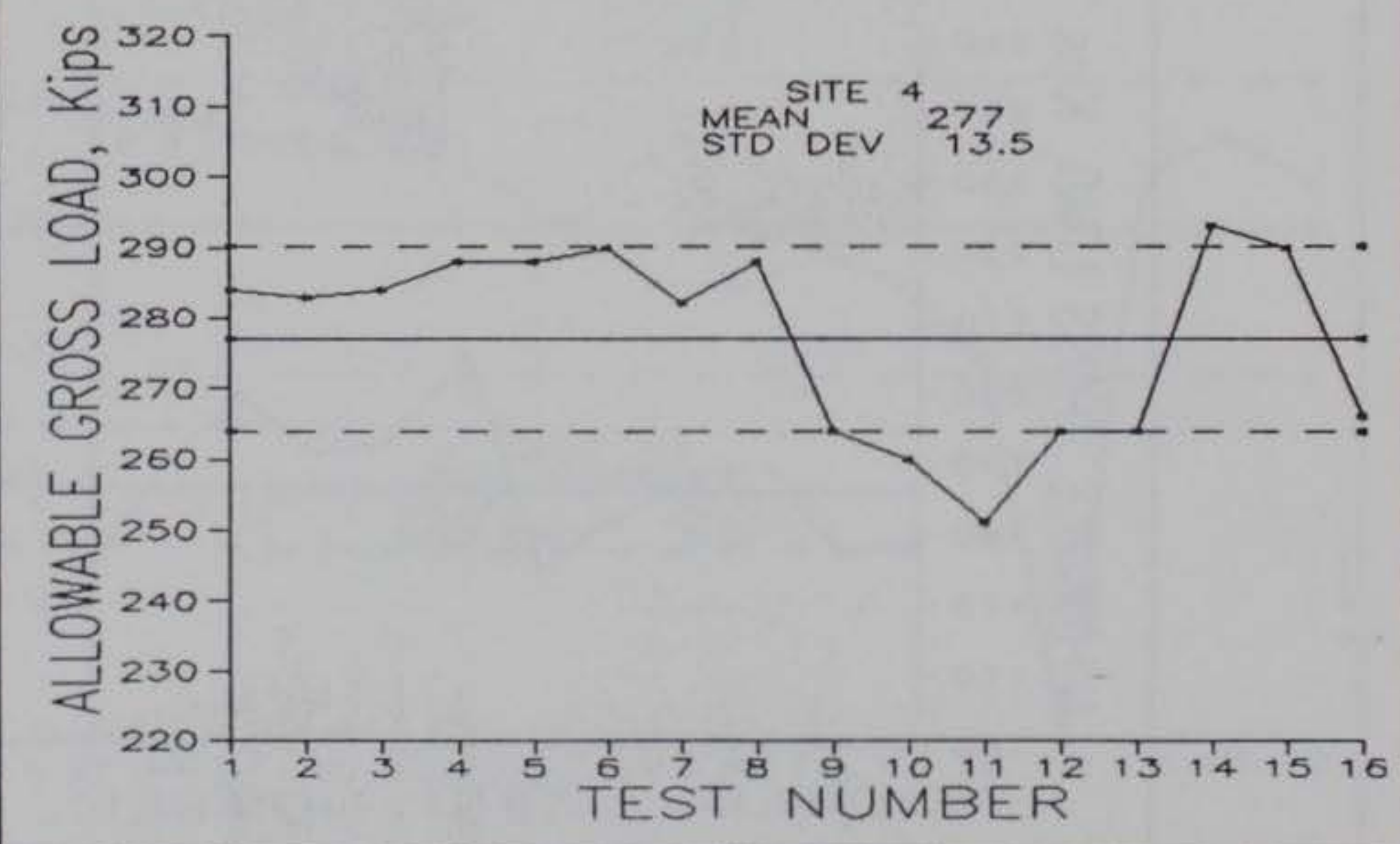

Figure 69.

Site 4, Allowable Gross Load vs Test Number 


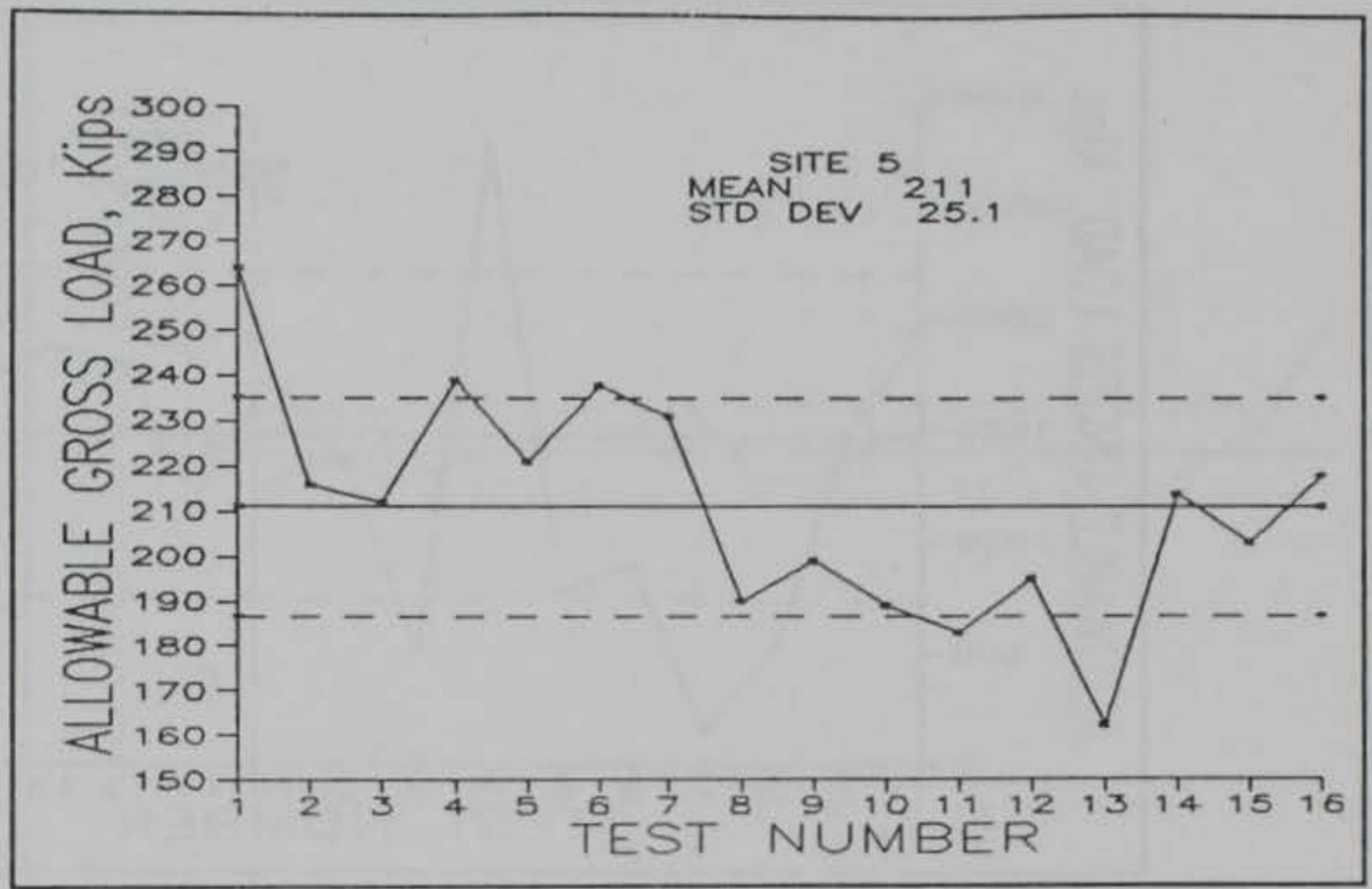

Figure 70 .

Site 5, Allowable Gross Load vs Test Number

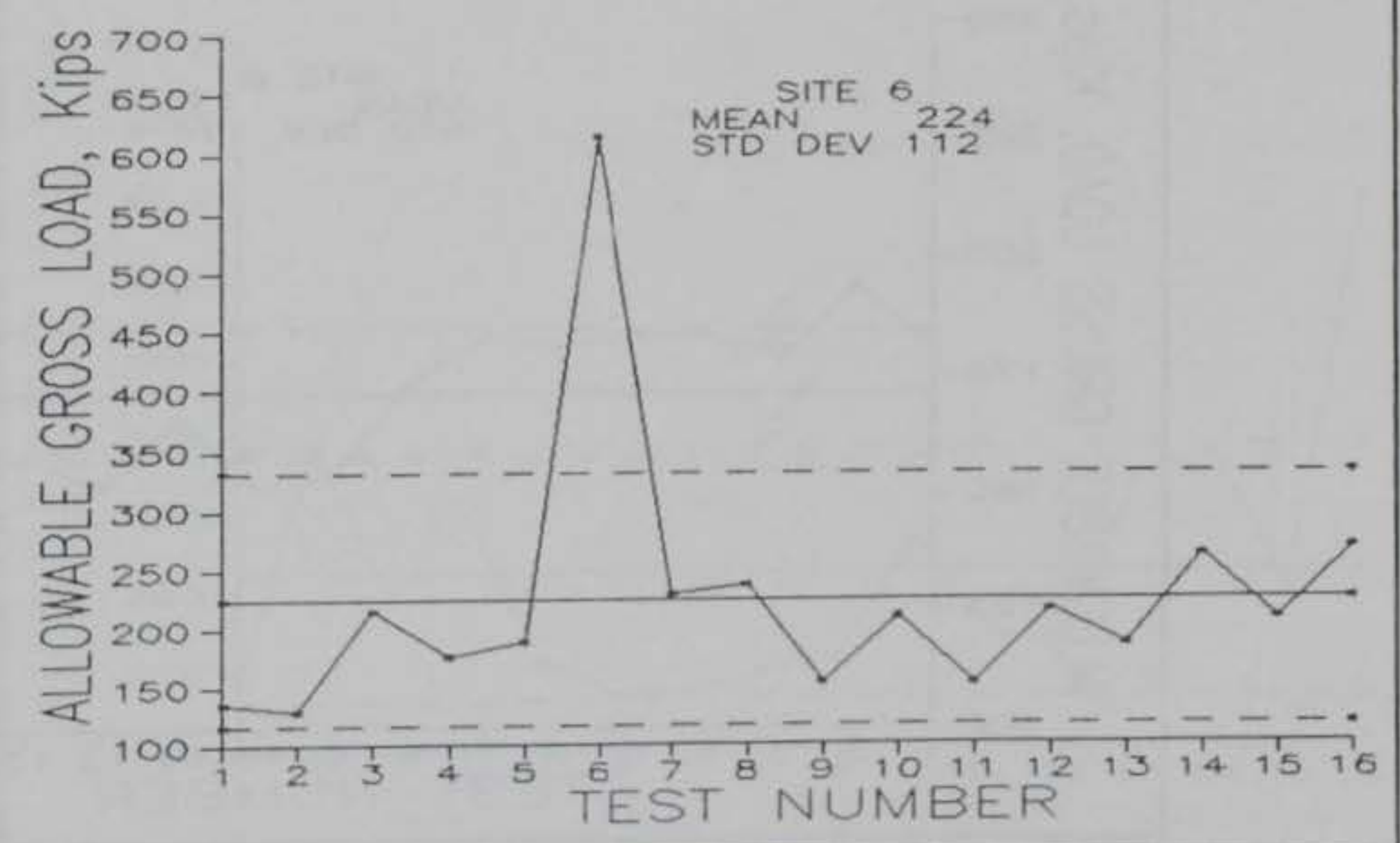

Figure 71.

Site 6, Allowable Gross Load vs Test Number 


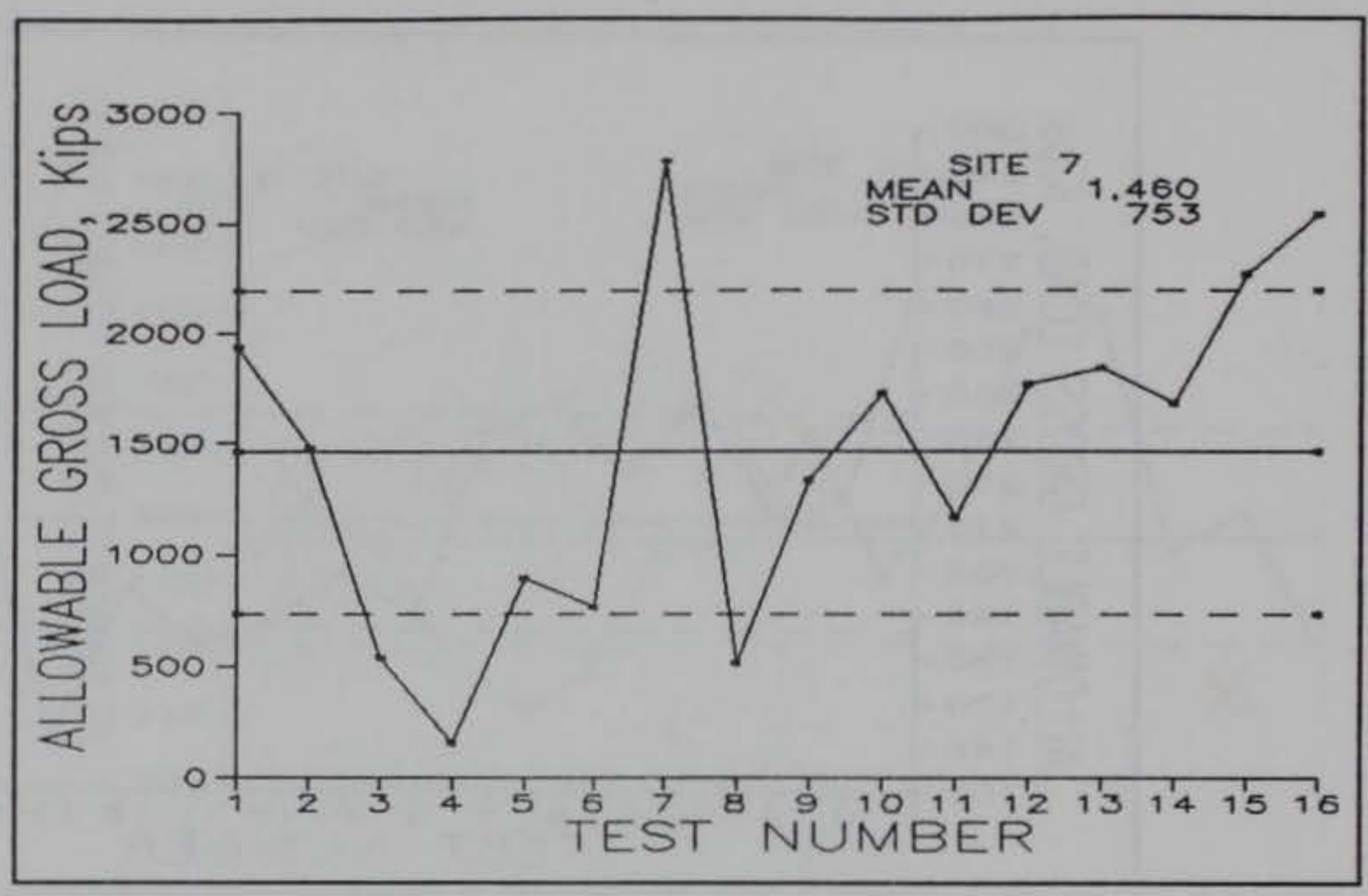

Figure 72 .

Site 7, Allowable Gross Load vs Test Number

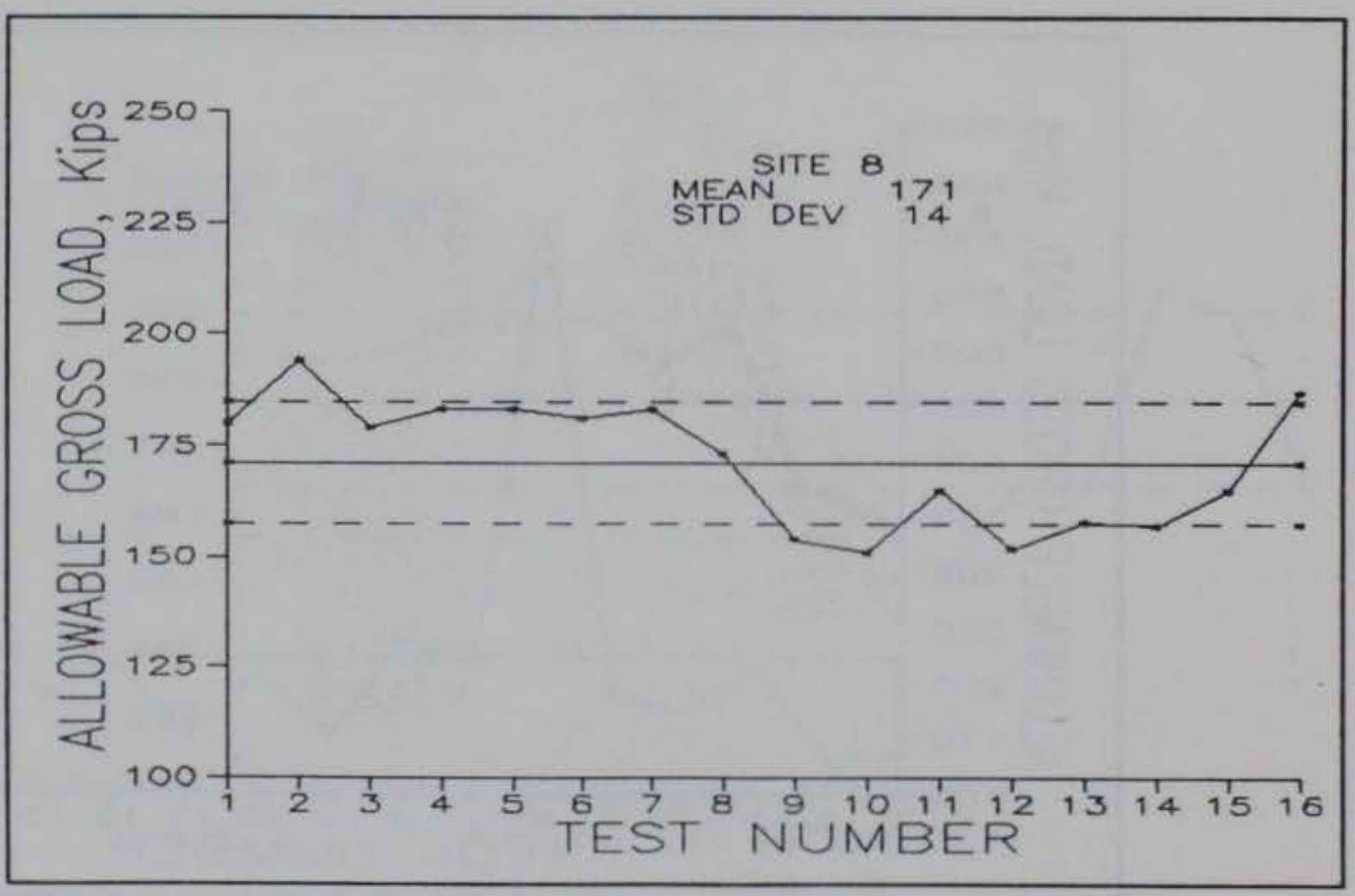

Figure 73.

Site 8, Allowable Gross Load vs Test Number 


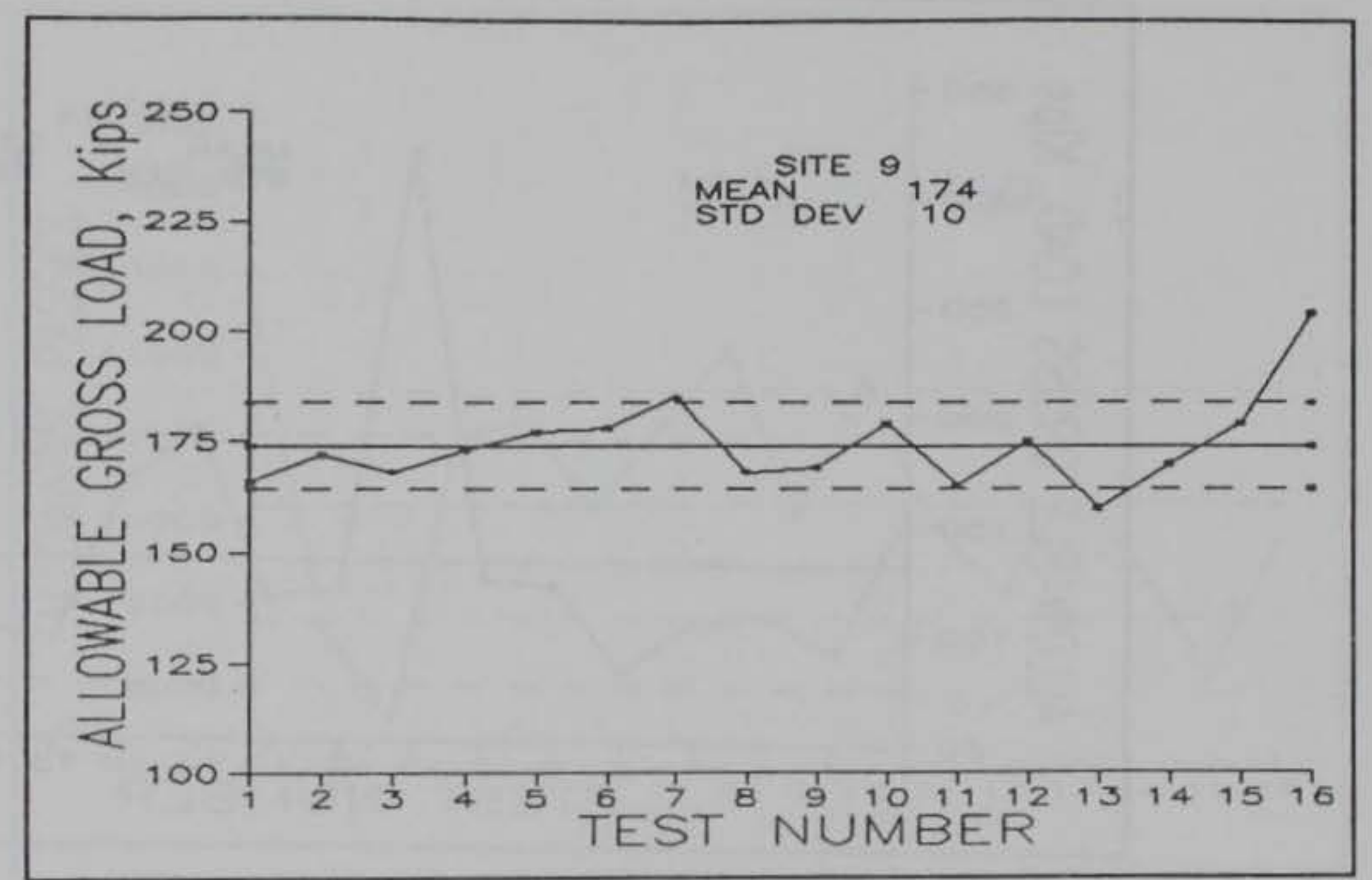

Figure 74 .

Site 9, Allowable Gross Load vs Test Number

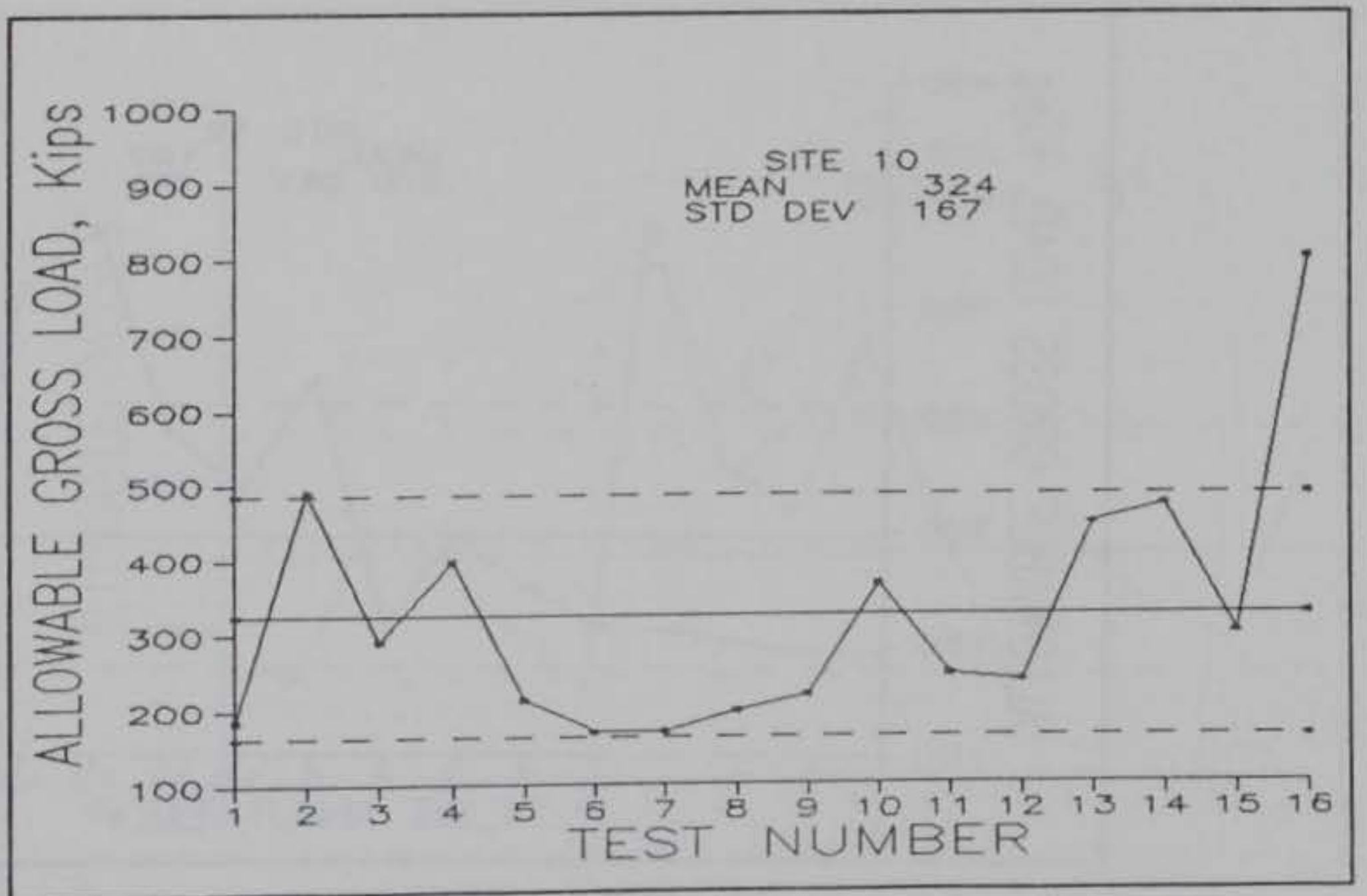

Figure 75.

Site 10, Allowable Gross Load vs Test Number 


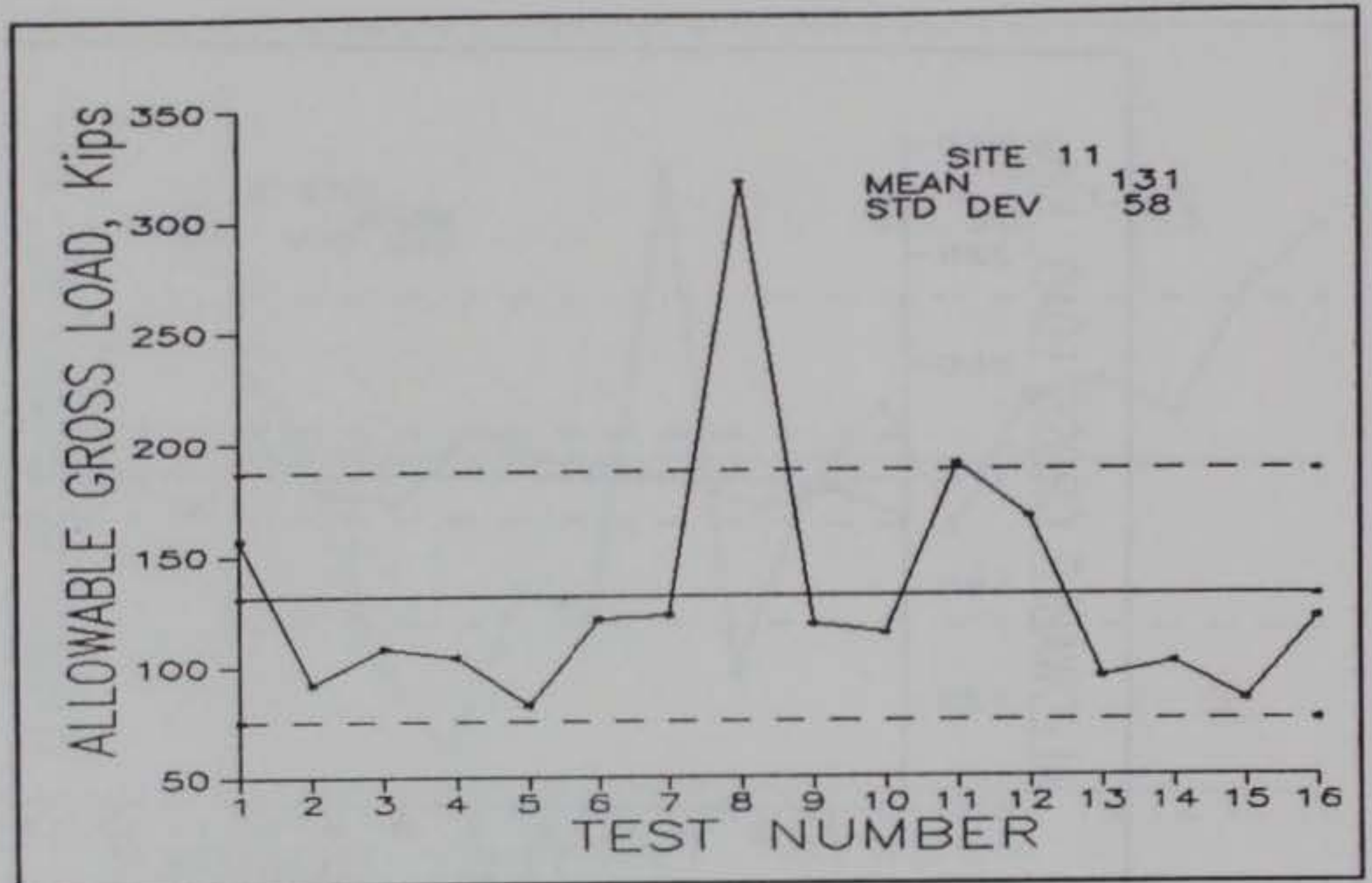

Figure 76.

Site 11, Allowable Gross Load vs Test Number

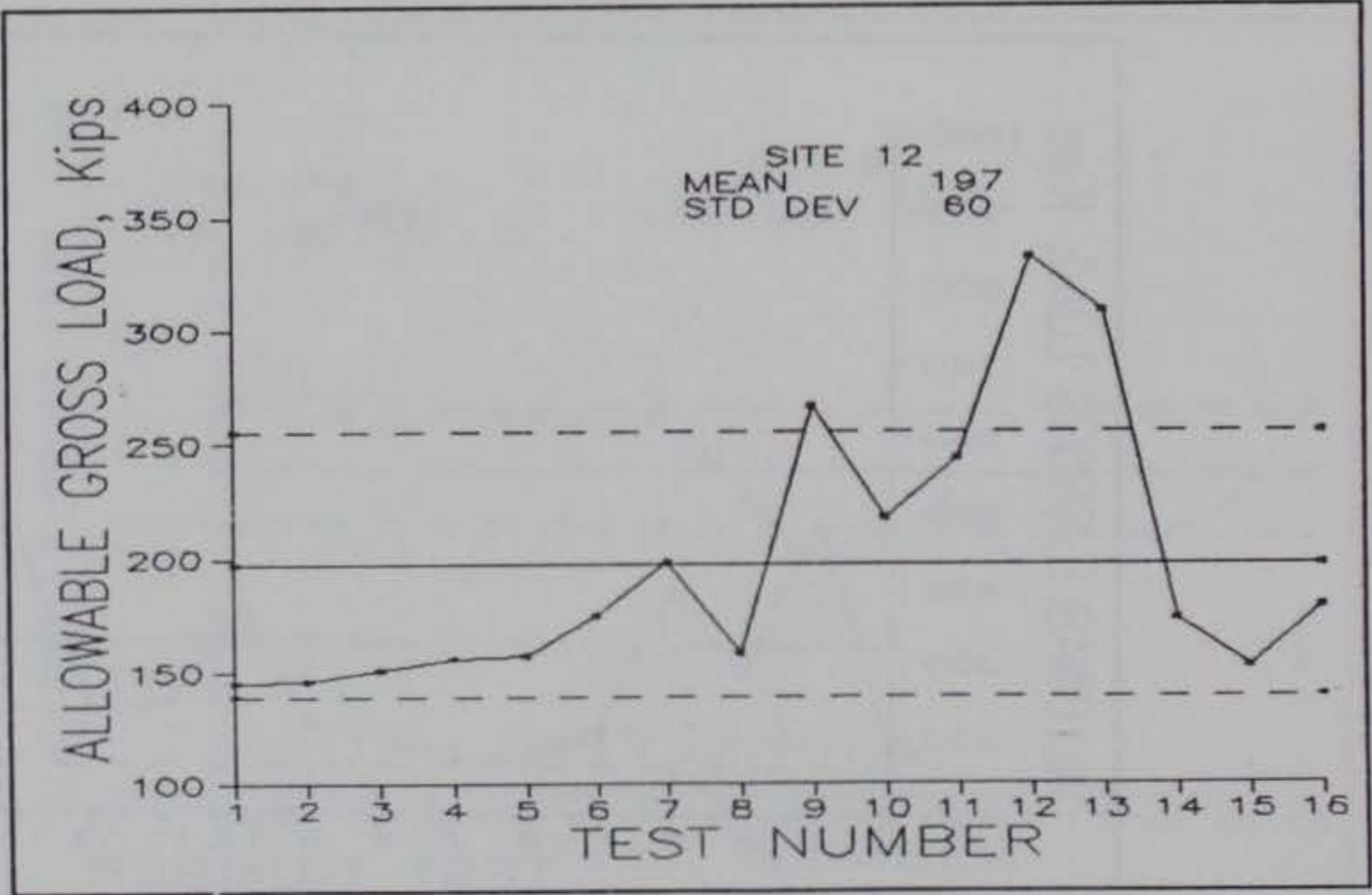

Figure 77.

Site 12, Allowable Gross Load vs Test Number 


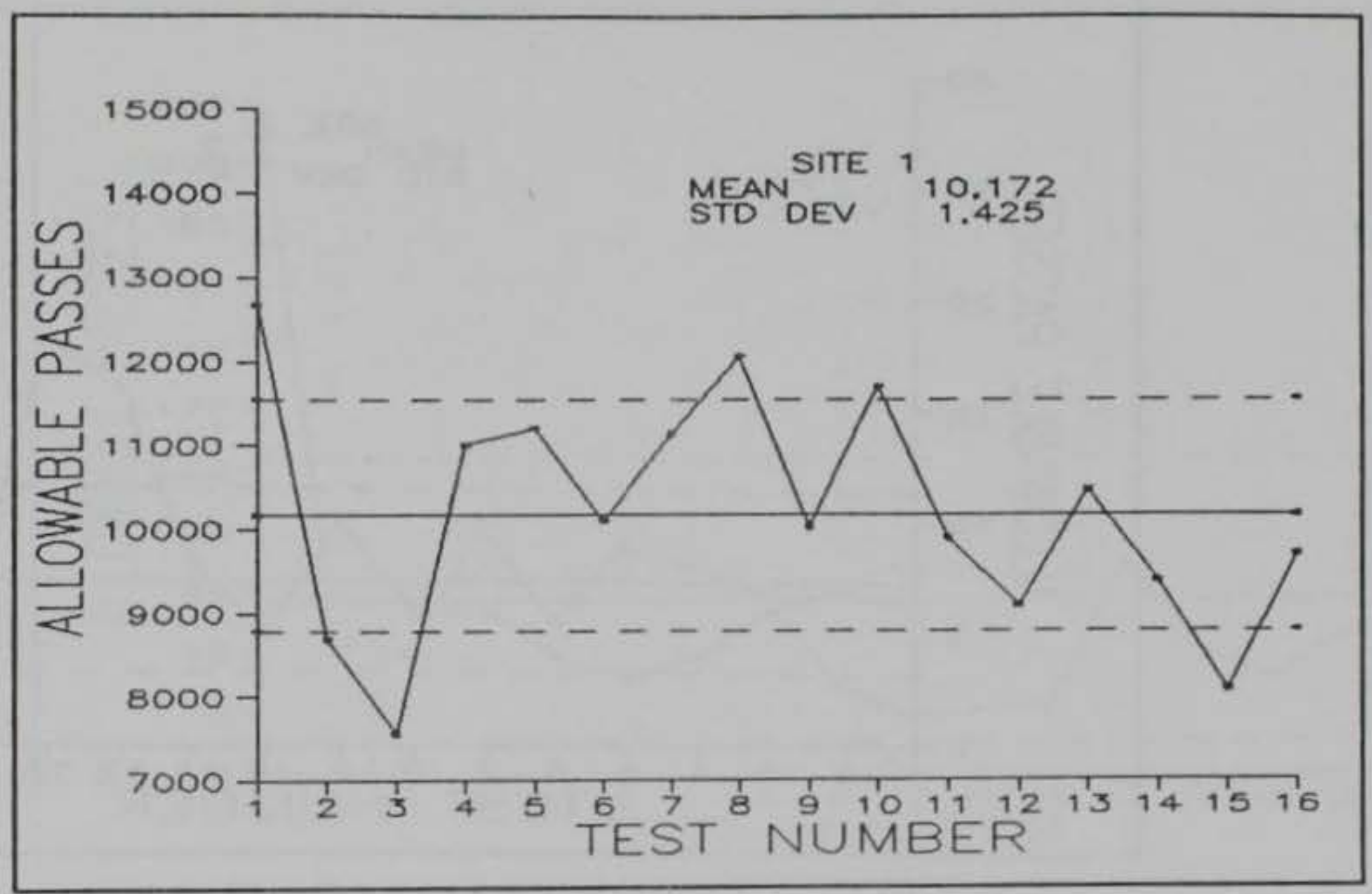

Figure 78.

Site 1, Allowable Passes vs Test Number

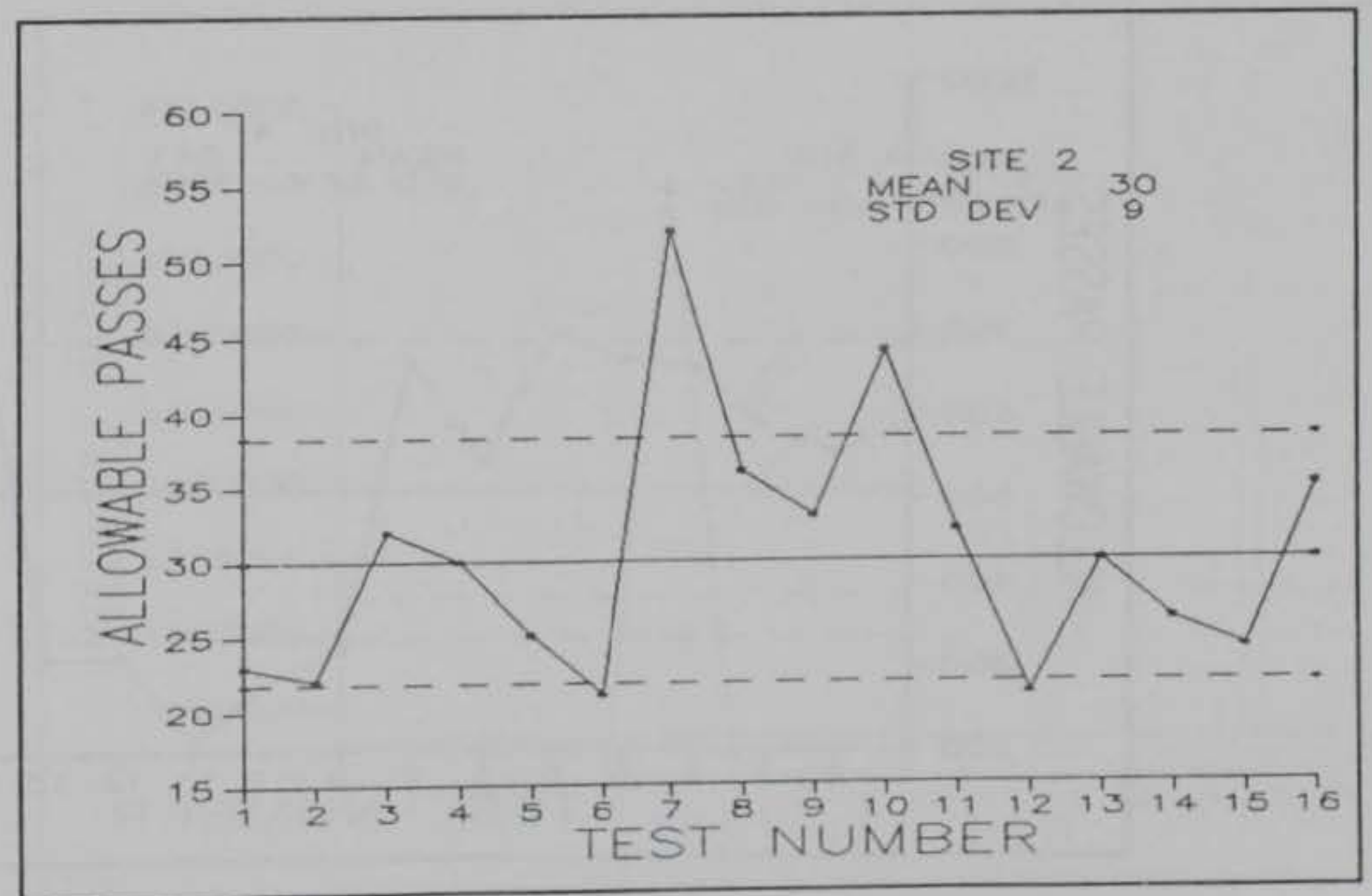

Figure 79.

Site 2, Allowable Passes vs Test Number 


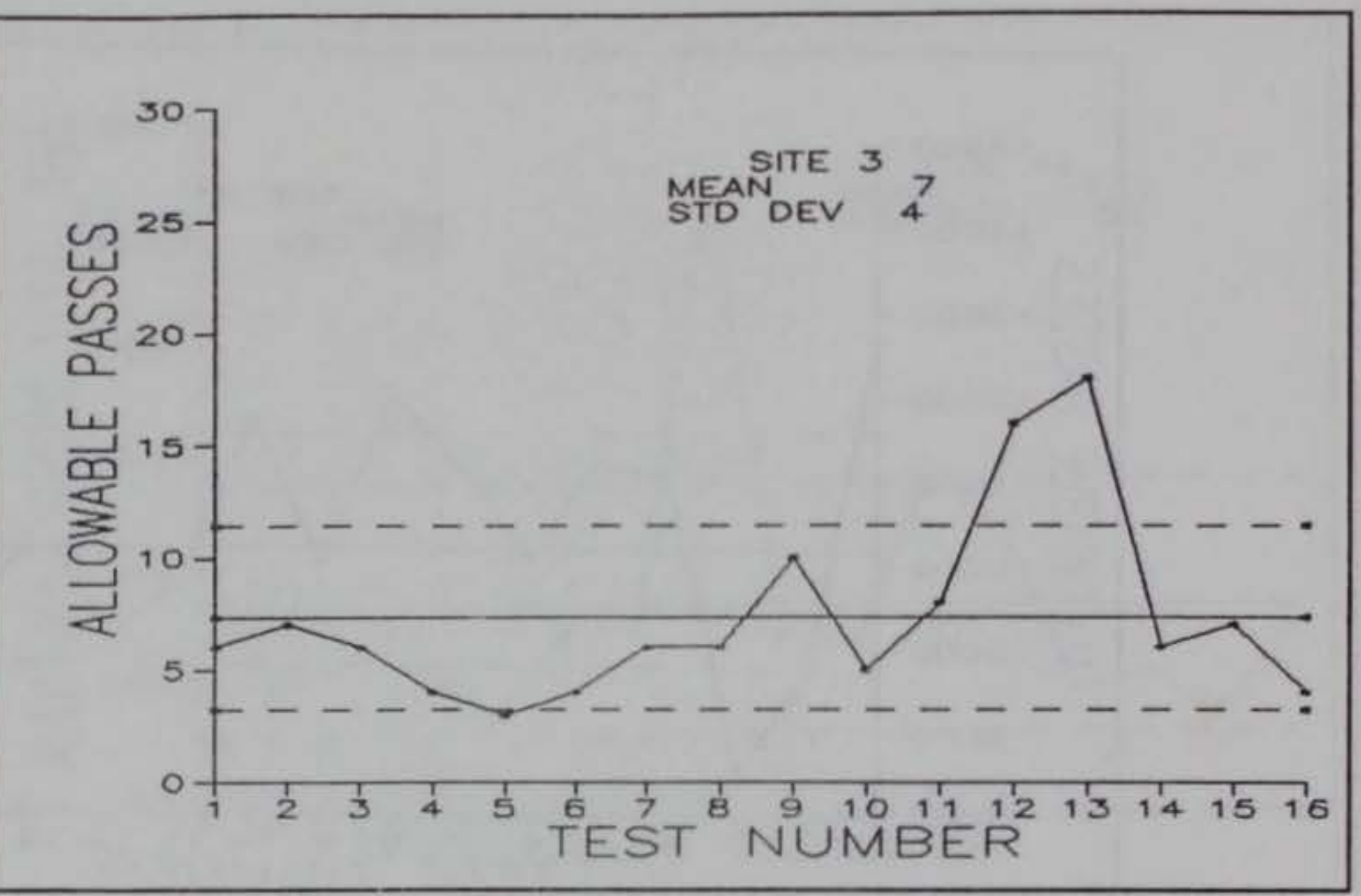

Figure 80.

Site 3, Allowable Passes vs Test Number

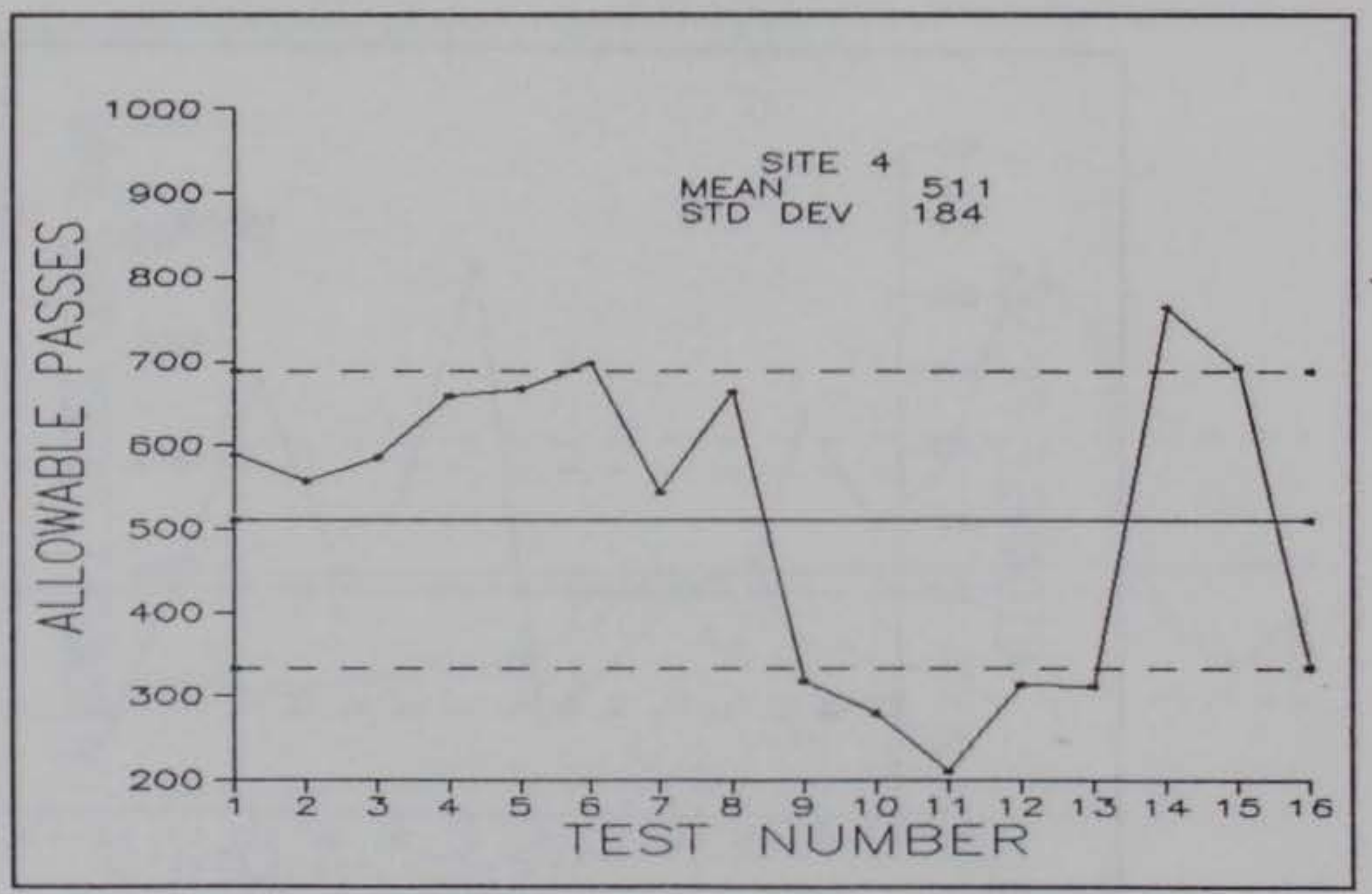

Figure 81.

Site 4, Allowable Passes vs Test Number 


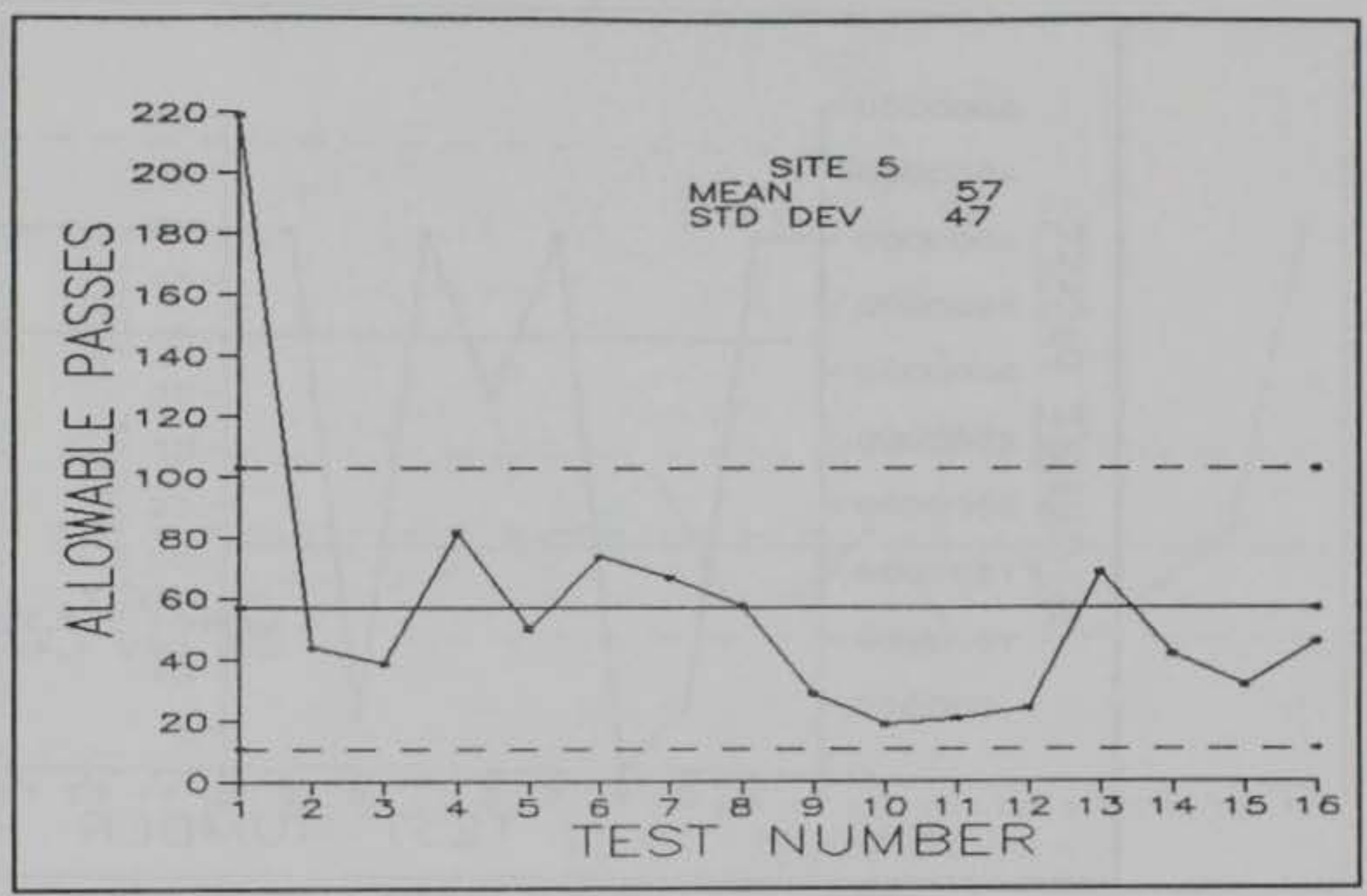

Figure 82 .

Site 5, Allowable Passes vs Test Number

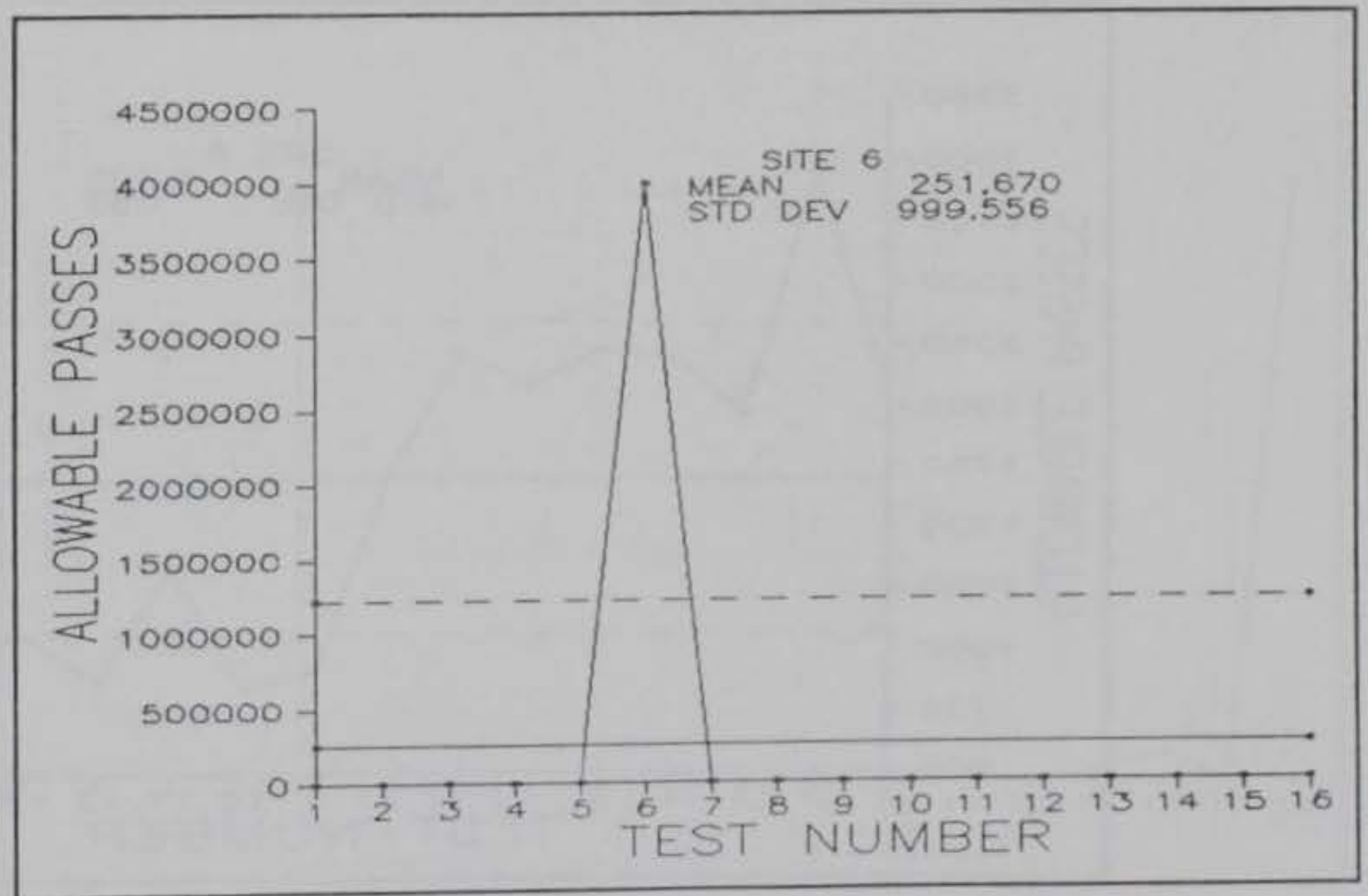

Figure 83.

Site 6, Allowable Passes vs Test Number 


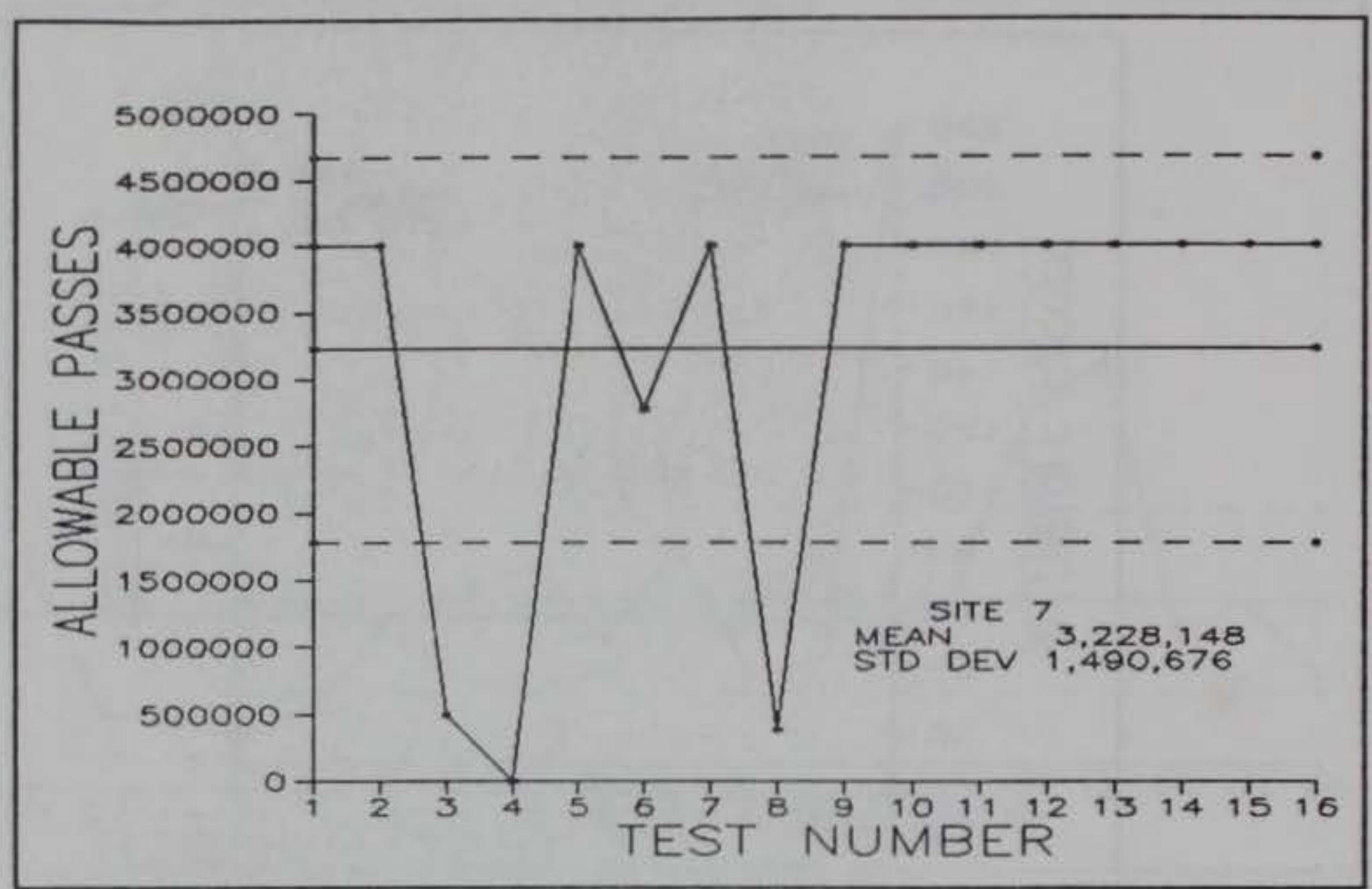

Figure 84.

Site 7, Allowable Passes vs Test Number

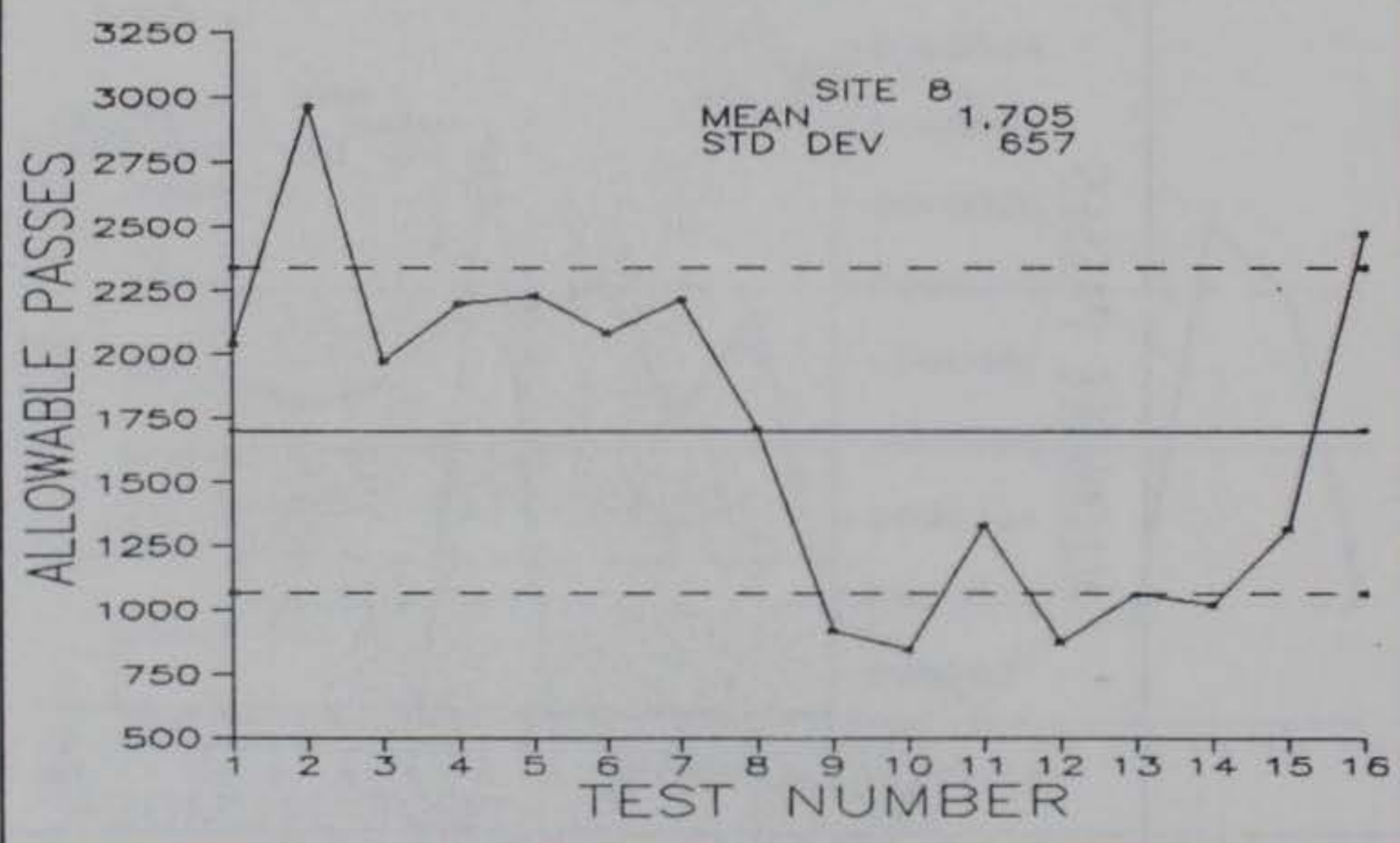

Figure 85.

Site 8 , Allowable Passes vs Test Number 


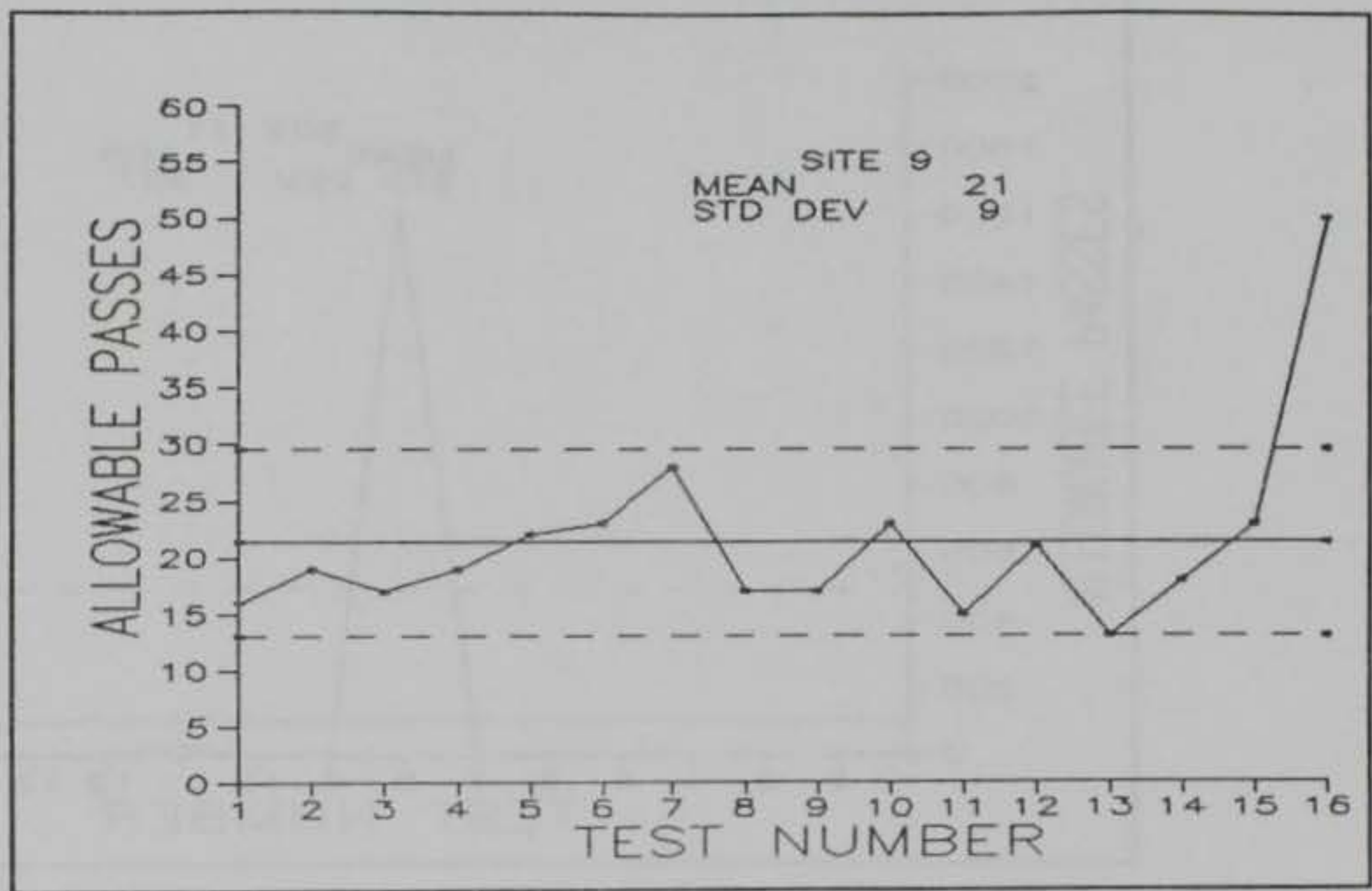

Figure 86.

Site 9, Allowable Passes vs Test Number

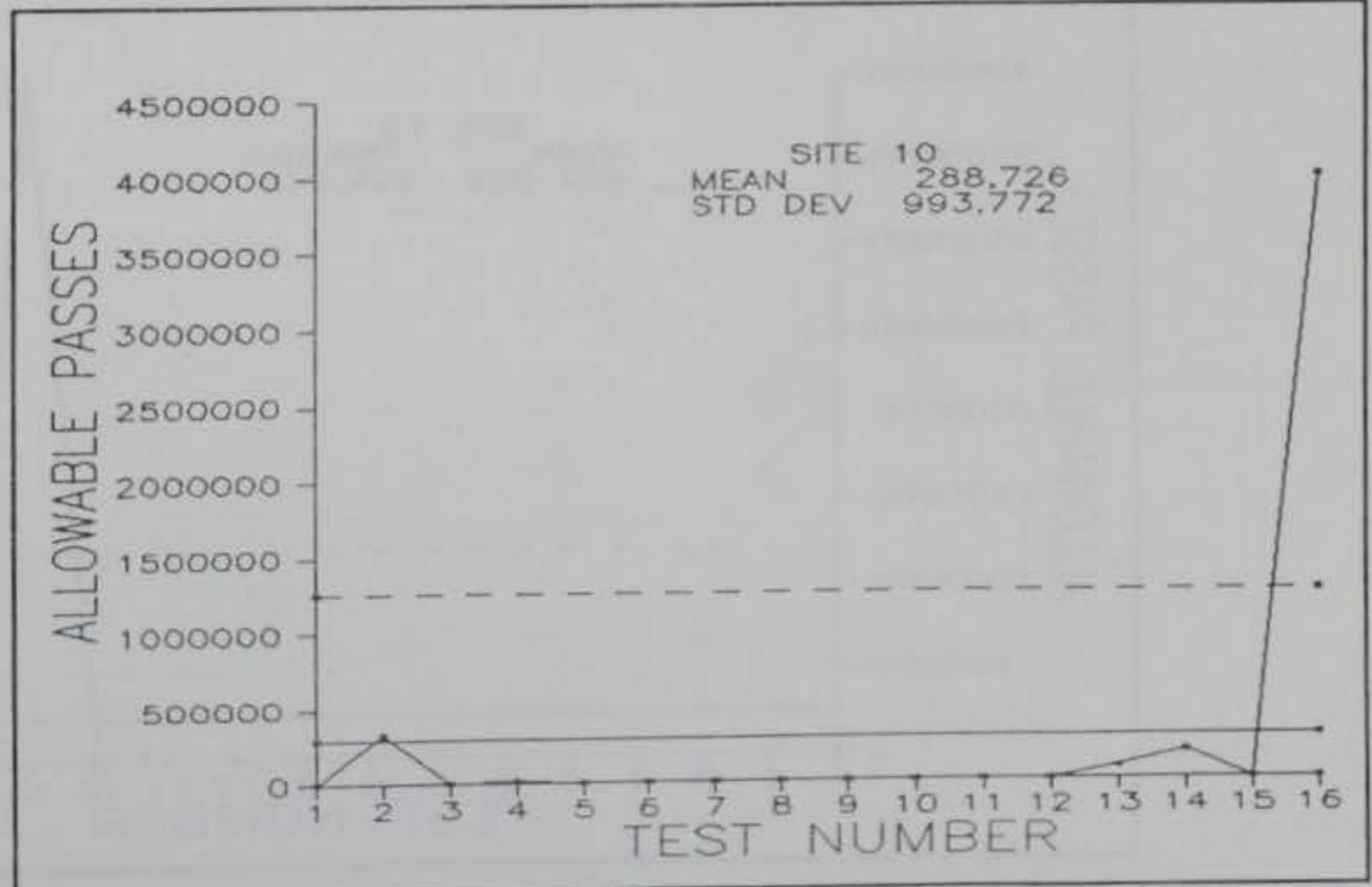

Figure o7.

Site 10, Allowable Passes vs Test Number 


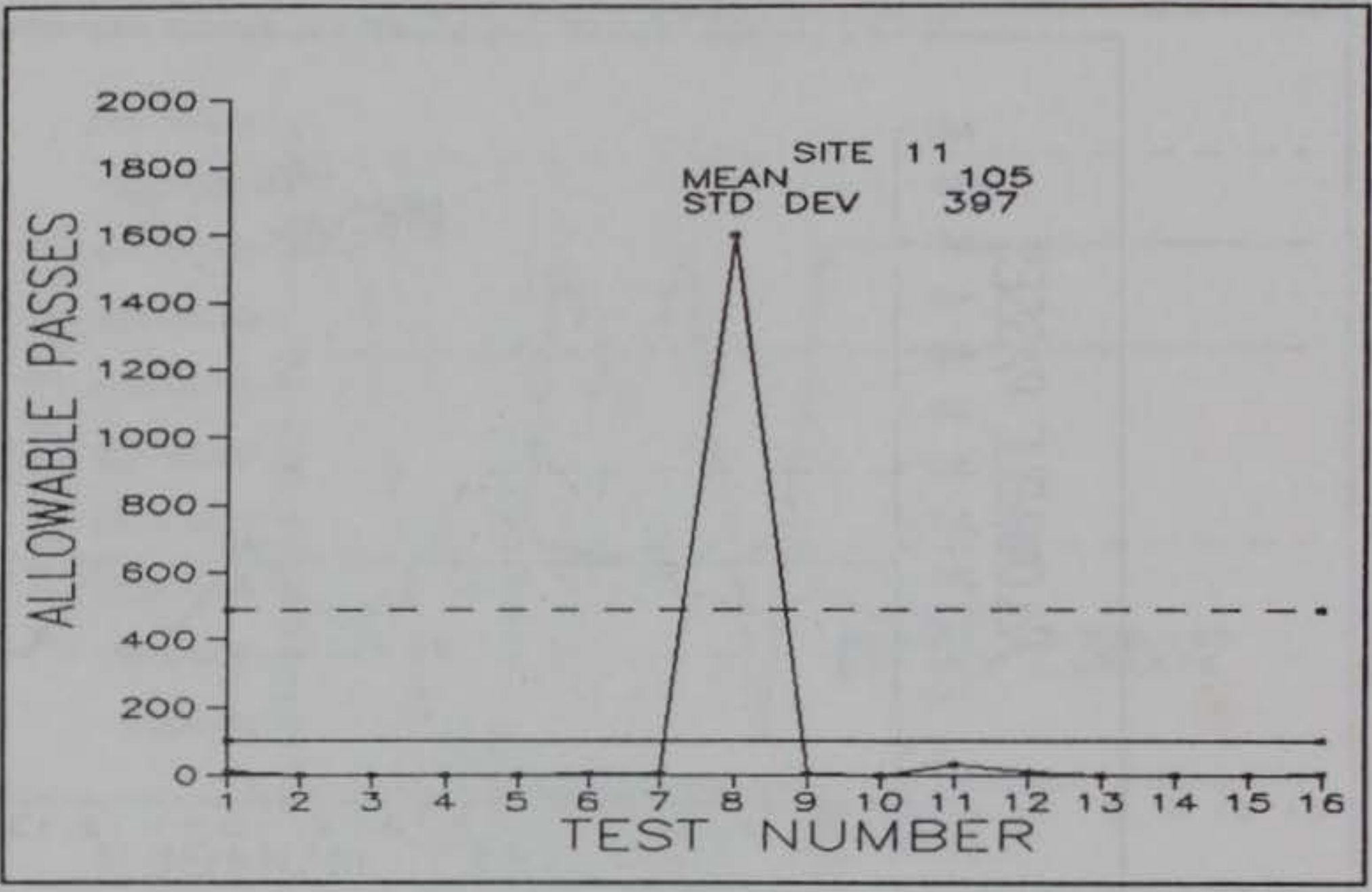

Figure 88.

Site 11, Allowable Passes vs Test Number

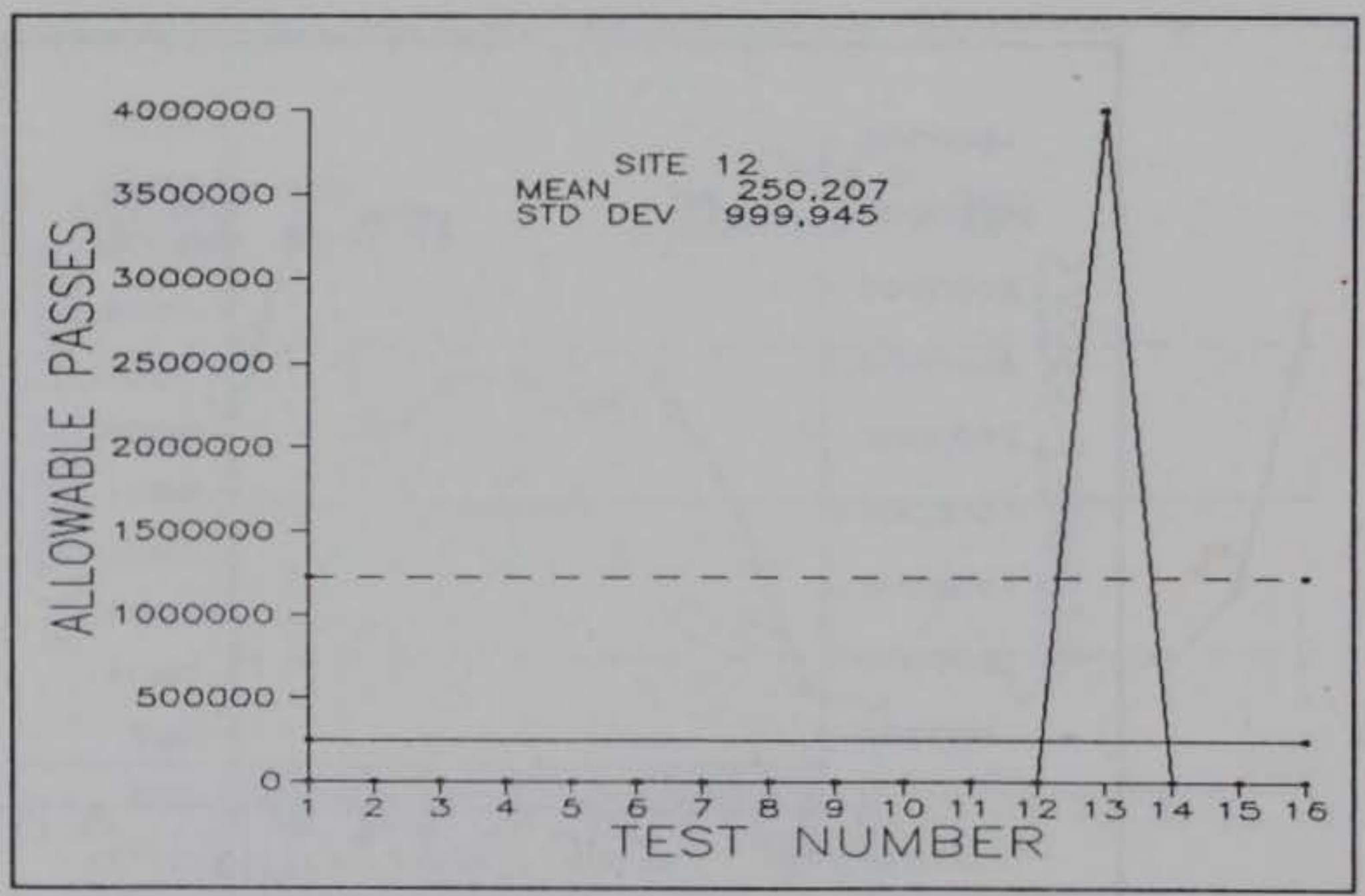

Figure 89.

Site 12, Allowable Passes vs Test Number 